\title{
Volcanic Processes and Geology of Augustine Volcano, Alaska
}

Professional Paper 1762

U.S. Department of the Interior U.S. Geological Survey

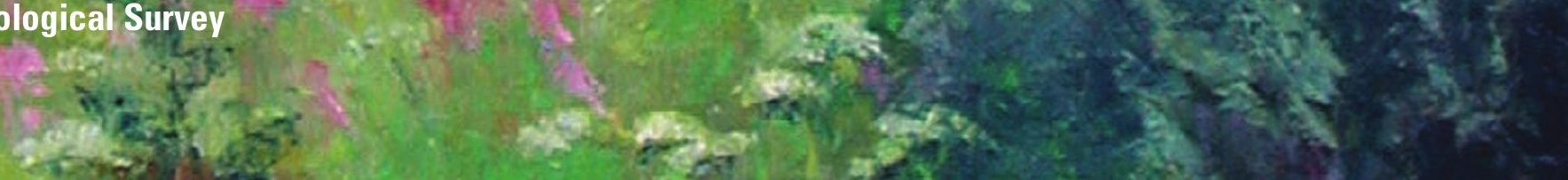


Front Cover: Photograph of en plein air painting by Josephine Crumrine from West Hills above Homer, Alaska, in June 1986 while viewing Augustine Volcano erupting 71 miles $(113 \mathrm{~km})$ away. Original oil on canvas hangs at Pratt Museum, Homer, Alaska. Image used by permission. 


\section{Volcanic Processes and Geology of Augustine Volcano, Alaska}

By Richard B. Waitt and James E. Begét

Debris avalanches, pyroclastic flows and surges, and ashfalls of the past few millennia at Augustine Volcano in lower Cook Inlet, Alaska, illuminated by historical photographs and a new topographic and geologic map

Professional Paper 1762 


\section{U.S. Department of the Interior \\ KEN SALAZAR, Secretary \\ U.S. Geological Survey \\ Suzette M. Kimball, Acting Director}

U.S. Geological Survey, Reston, Virginia: 2009

This report and any updates to it are available at:

http://pubs.usgs.gov/pp/1762

For more information on the USGS - the Federal source for science about the Earth, its natural and living resources, natural hazards, and the environment, visit tttp://www.usgs.gov or call 1-888-ASK-USGS

For an overview of USGS information products, including maps, imagery, and publications, visithttp://www.usgs.gov/pubprod

To order this and other USGS information products, visit http://store.usgs.gov

Any use of trade, product, or firm names is for descriptive purposes only and does not imply endorsement by the U.S. Government.

Although this report is in the public domain, permission must be secured from the individual copyright owners to reproduce any copyrighted materials contained within this report.

Suggested citation:

Waitt, R.B., and Begét, J.E., 2009, Volcanic processes and geology of Augustine Volcano, Alaska:

U.S. Geological Survey Professional Paper 1762, 78 p., 2 plates, scale 1:25,000.

Cataloging-in-publication data are on file with the Library of Congress (http://www.loc.gov/). 


\section{Contents}

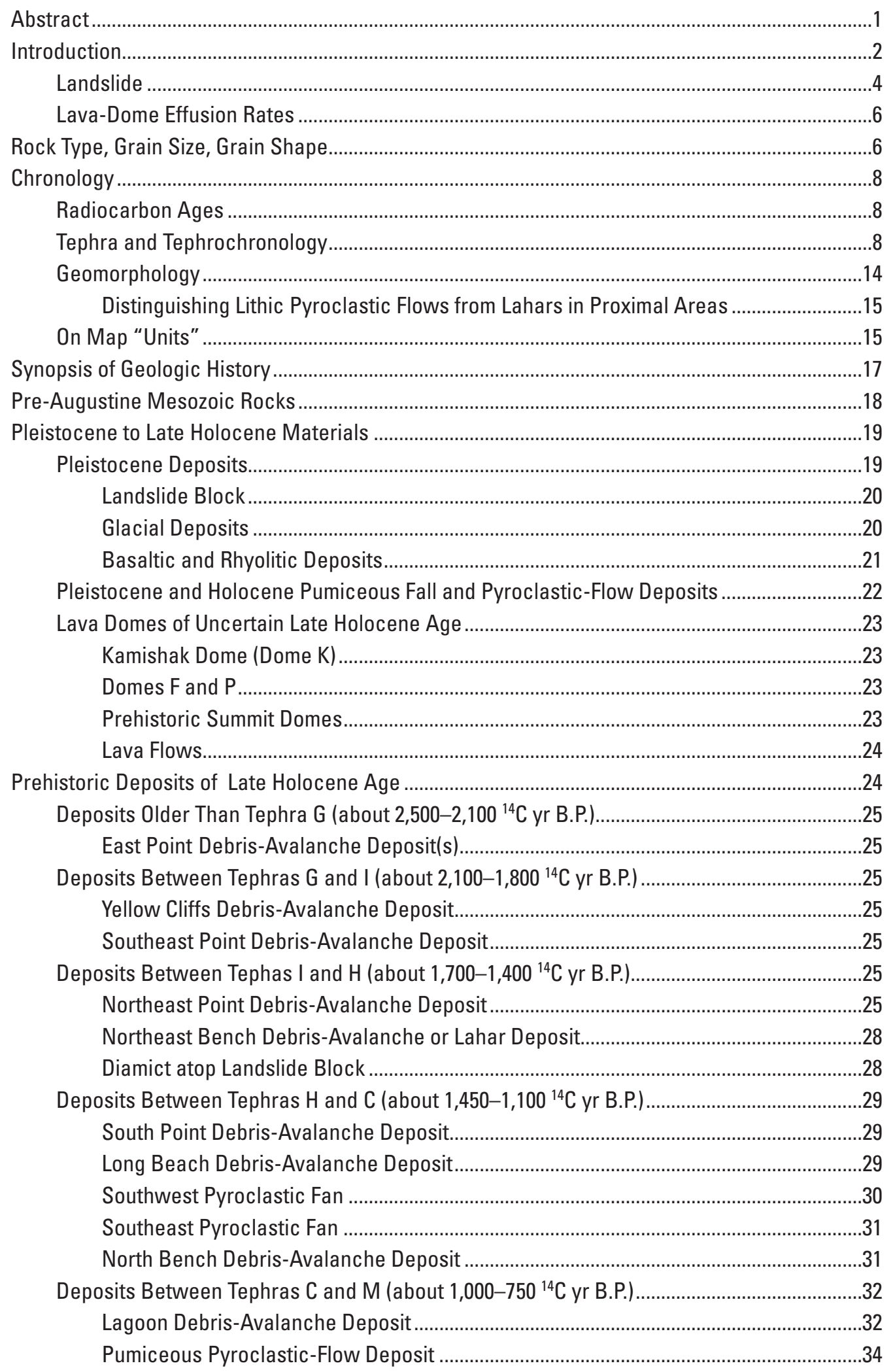


Lithic Pyroclastic-Flow (or Lahar?) Deposit .....................................................................34

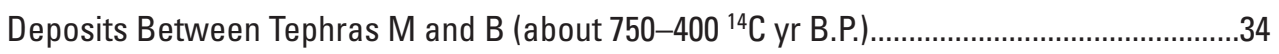

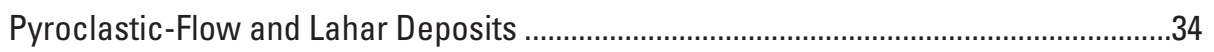

Southeast Beach Debris-Avalanche Deposit ...................................................................34

Deposits Younger than Tephra B (younger than about $400{ }^{14} \mathrm{C}$ yr B.P.) .....................................34

West Island Debris-Avalanche Deposit............................................................................

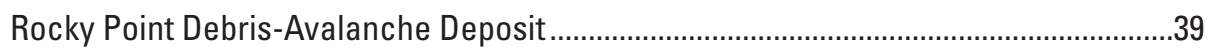

Unassigned Debris-Avalanche Deposits .........................................................................39

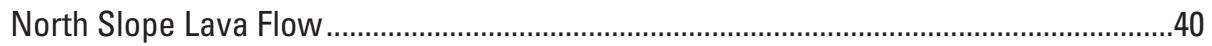

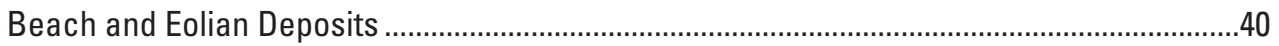

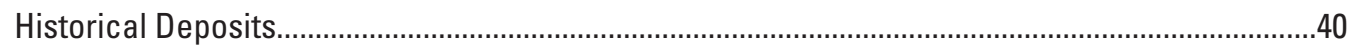

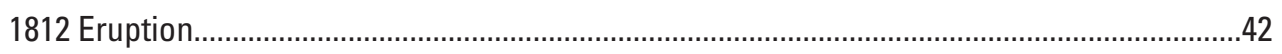

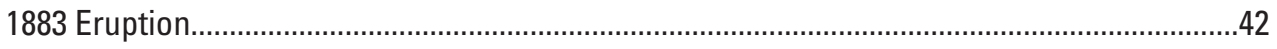

Burr Point Debris-Avalanche Deposit ........................................................................

Pyroclastic-Flow and Surge Deposits .........................................................................47

Lava Dome

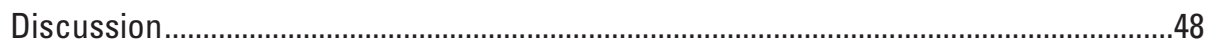

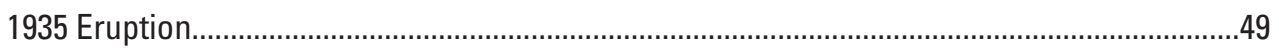

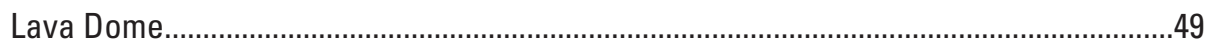

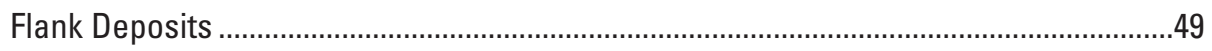

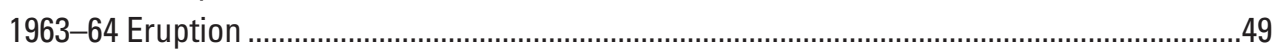

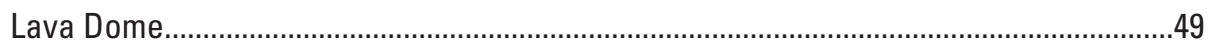

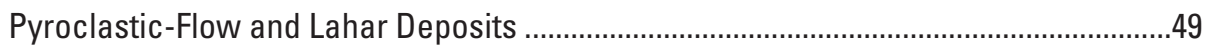

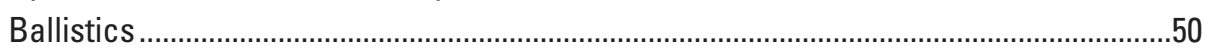

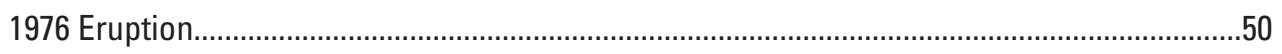

Pyroclastic-Flow, Surge, and Lahar Deposits ...........................................................50

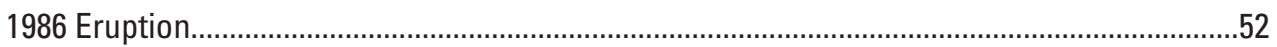

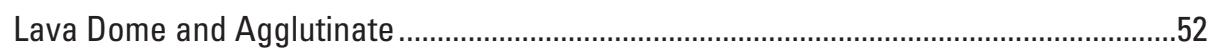

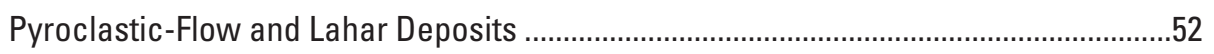

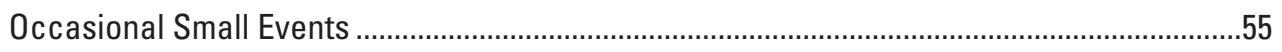

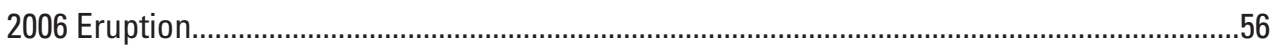

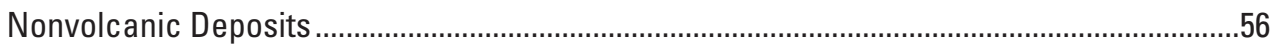

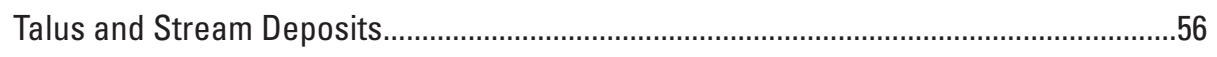

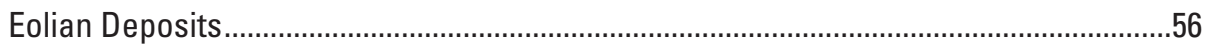

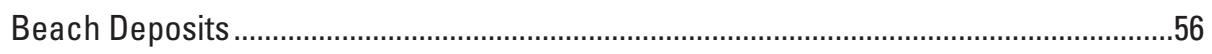

Tidal-Flat Deposits and Marsh Deposits .....................................................................57

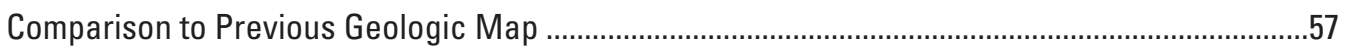

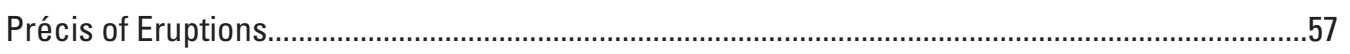

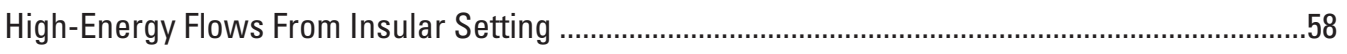

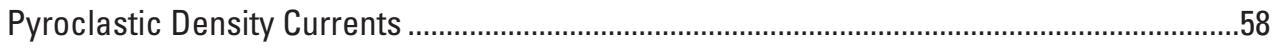

Debris Avalanche and Surge ("Blast") ..........................................................................58

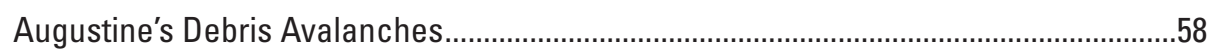

Mobility and Speed of Volcanic Debris Avalanches...................................................59

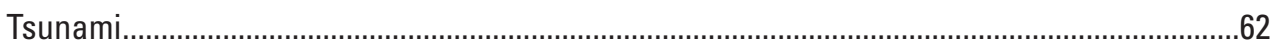

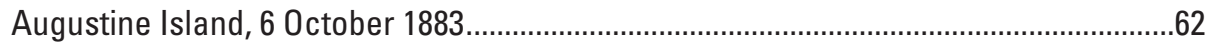

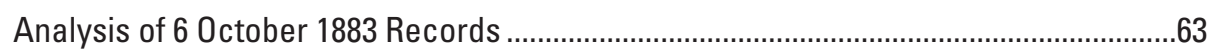


Evidence on Augustine Island for Augustine Tsunami ......................................................66

Evidence on Mainland for Augustine Tsunami ............................................................66

Sparseness of Mainland Evidence for Augustine Tsunami ..............................................67

Numerical Simulation of Augustine Tsunami .................................................................68

Can Augustine Generate Large Tsunami? ......................................................................68

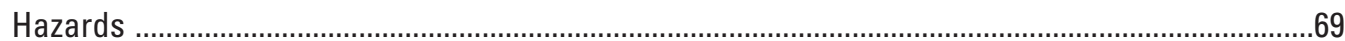

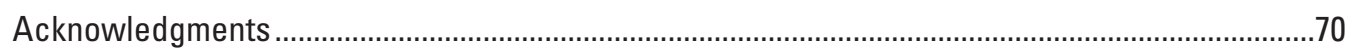

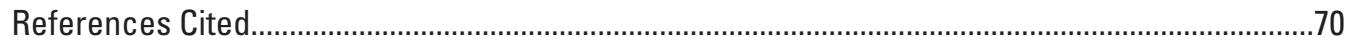

\section{Plates [in pocket]}

1. Map showing the geology of Augustine Island, Alaska.

2. Map showing measured sections on Augustine Island and Shuyak Island, Alaska.

\section{Figures}

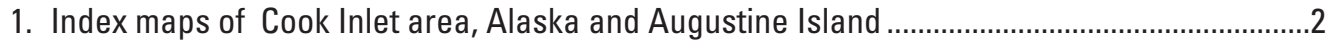

2. Photo looking south-southwest of Augustine Volcano ..............................................................

3. Oblique aerial photo looking northeast of Augustine Island and Augustine Volcano ................6

4. Plot of chemical composition analyses of volcanic rocks (whole-rock analyses) and tephra (glass-separate analyses) from Augustine Island.............................................................

5. Summary of mean annual wind directions 1949-62 ..........................................................12

6. Tephra stratigraphy overlying flowage deposits on Augustine Island just north of

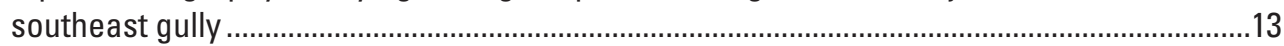

7. Isopach maps of coarse pumiceous tephra-layers on Augustine Island ................................. 14

8. Graph showing thickness of some sheets of tephra erupted from volcanoes in western United States plotted against distance downwind ..................................................................

9. Summary of eruptive history of Augustine Volcano based on data in this report.....................16

10. Sketch showing in profile development of arrested sea cliffs at Augustine Island...................16

11. Map showing offshore distribution of debris avalanches off Augustine Volcano based on seaward extent of conspicuously hummocky submarine topography.....................18

12. Oblique aerial photo looking north-northwest of Augustine Volcano.........................................19

13. Photo showing Naknek Formation (Jurassic) on south side of Augustine Island .....................20

14. Photo showing great landslide block capped by layered Augustine-volcanic debris, south coast Augustine Island.

15. Photo showing view north of glacial till containing striated exotic stones and associated glacial drift (g) overlain by dacitic fall pumice of Augustine Volcano......

16. Photo looking eastward showing bedded olivine-basalt hyaloclastite at or near base of discontinuously exposed volcanic materials of Augustine Volcano.

17. Photo showing basaltic hyaloclastite overlain by dacite pumice on south flank of Augustine Island

18. Photo showing pumice-fall deposit from Augustine interbedded with distal thin beds of Pleistocene glacial outwash, south-southwest flank of volcano

19. Oblique aerial photo looking toward east-southeast of Augustine Volcano summit area including landslide-truncated prehistoric summit-dome complex. 
20. Photos showing details within East Point debris-avalanche deposit..........................................26

21. Photo showing view of sea cliff along Augustine Island east shore ..........................................27

22. Photo showing Southeast Point and Northeast Point debris-avalanche deposit .....................27

23. Schematic sketch of coastal cliffs along east side of Augustine Island showing stratigraphic relations of four oldest debris-avalanche deposits.

24. Photo showing view west of hummocky surface of Northeast Point debris-avalanche deposit.

25. Oblique aerial photo looking west-southwestward of prominent huge-boulder "mound" area of hummocky Northeast Point debris-avalanche deposit, Augustine Island

26. Oblique aerial photo looking west-northwestward of Augustine's Northeast Point debris-avalanche deposit and apparently overridden sea cliff.

27. Photo showing nine-meter megaclast of summit-dome porphyritic andesite forming a single hummock of Long Beach debris-avalanche deposit on lower southwest flank of Augustine Island

28. Photo looking northwest of boulders on southeast pyroclastic fan of Augustine Island .........31

29. Vertical aerial photo of Augustine's north flank showing dome complex, North Slope lava flow and the debris-avalanche deposits

30. Oblique aerial photo looking south-southeast showing North Slope lava flow, arrested sea cliff cut in North Bench debris-avalanche deposit, Rocky Point debris-avalanche deposit, and 1883 debris-avalanche levee across and below the lava flow.

31. Photo looking west-northwest from high on cone of Augustine Volcano showing West Island, one of the largest of Augustine's debris-avalanche deposits.

32. Photo showing oblique aerial view southwestward of Augustine Volcano and its offshore West Island

33. Photo showing coastal sea cliff exposing interior of debris-avalanche hummock on West Island, just off Augustine Island.

34. Photo looking southeastward of southwest side of central core of high conical hummocks of West Island debris-avalanche deposit.

35. Stratigraphic section showing succession atop debris-avalanche hummock on southwest coast of West Island

36. Sketch map showing details of Grouse Point area, Augustine Island

37. Oblique aerial photos of oddly planed-off hummocks on southwest part of West Island, at Augustine Island.

38. Photo looking northeast of southwestmost part of Augustine's West Island showing oddly flattened hummocks.

39. Photo showing Bouldery diamict of debris-avalanche levee resting atop North Slope lava flow, north flank of Augustine Volcano.....

40. Photos and a sketch of Augustine Volcano showing large-scale effects to summit area by 1883 eruption...

41. Photographic portraits of George Davidson

42. Oblique aerial photo of Augustine Volcano from the north showing hummocky deposit about Burr Point deposited by landslide of 6 0ctober 1883.

43. Photos showing eastern cluster of hummocks of 1883 Burr Point debris avalanche, Augustine Island.. 
44. Schematic sketch of stratigraphic relations at seaside hummocks east of Burr Point ...........46

45. Oblique aerial photos of Augustine Volcano showing 1935, 1883 and 1935 domes...................47

46. Photo of Augustine Volcano from southwest showing large steaming dome and below it a light-colored fan of debris.....................................................................................

47. Photo looking south-southeast of summit-dome complex showing 1976 dome nested below summit.............................................................................................................

48. Photos looking westward of Augustine Volcano summit area ..................................................50

49. David A. Johnston's "isodroop" curve from an experiment of melting plastic like that at Burr Point hut in the 1976 eruption .......................................................................51

50. Photo looking southward in then-new 1986 dome and lava-flow tongue at its base ...............52

51. Photo looking north-northeast of Augustine's 1935 and 1986 domes, from 1964 dome ............53

52. Photo showing lithic-fall beds at summit domes of Augustine Volcano that bury the former rough-surfaced crescent of the 1976 dome...................................................................53

53. Photo looking southwest of moving 1986 pyroclastic flow that issued from collapsing lava dome flowing down lower Augustine's north flank near Burr Point................54

54. Photo looking east on lower north flank of Augustine Island showing imbricated

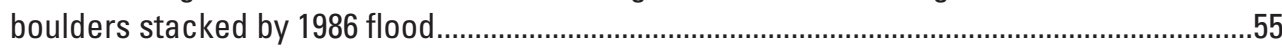

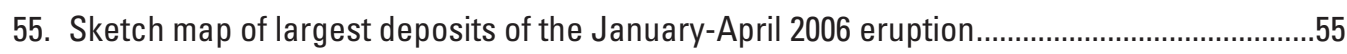

56. Plot of fall versus runout for volcanic debris avalanches from around the world ....................59

57. Profiles of large landslides................................................................................................

58. Schematic sketch illustrating how the stilling well in tide gauges causes a decrease in recorded wave height and a delay in recorded peak height from the actual wave

59. Tide-gauge marigram from St. Paul (Kodiak), Alaska on 6 October 1883 showing arrivals of wave train of air wave and of tsunami from Augustine ............................................62

60. Map showing tsunami travel times from north flank of Augustine Island .................................63

61. Timing of contemporary records of initial events in morning 6 0ctober 1883 eruption of Augustine Volcano .........................................................................................................64

62. Plot of variation in tidal ranges at Kodiak, Seldovia, and English Bay, Alaska ........................65

63. Photo showing 1883 tsumani and ashfall deposits near Nanwalek...........................................66

64. Photo of core from Beluga Lagoon near Homer with sand-gravel bed of 1883 Augustine tsunami.

\section{Tables}

1. Summary of previous geologic work bearing on description of rocks and deposits at Augustine Volcano...

2. Radiocarbon ages and stratigraphy of tephra layers at Augustine Volcano .............................9

3. Stratigraphy of coarse pumiceous "marker-bed" tephra layers and debris-avalanche deposits at Augustine Volcano.

4. Some historical tsunami caused by nonvolcanic landslides and by volcanic debris avalanches. 


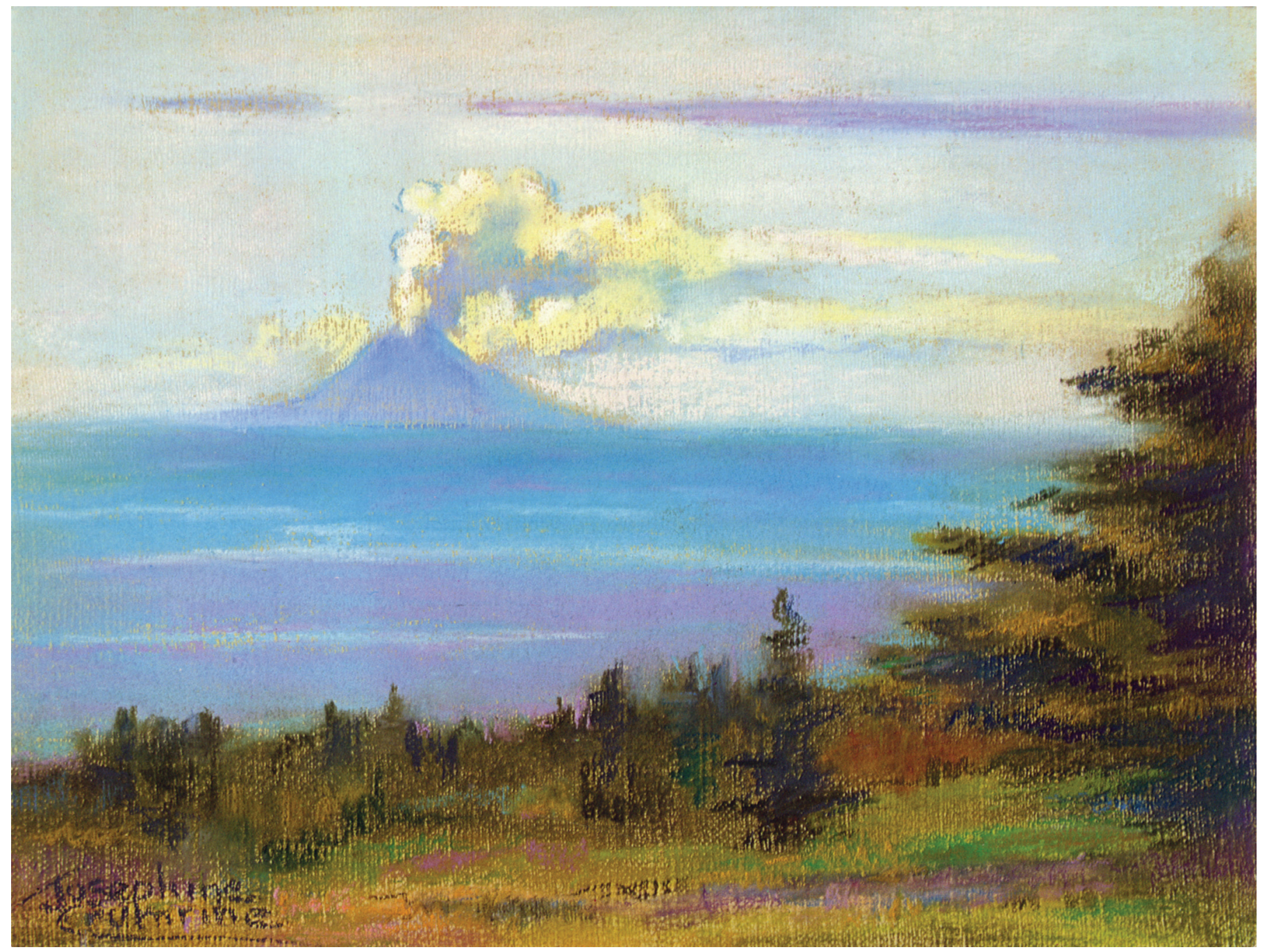

Image of an original pastel on canvas by artist Josephine Crumrine painted en plein air at Homer, Alaska, while viewing Augustine Volcano at about 13:30 on 9 June 1986. Small eruption clouds occurred late in the 1986 Augustine eruption when parts of the still-growing summit dome repeatedly collapsed into small pyroclastic flows (see fig. 53). Used by permission. 


\title{
Volcanic Processes and Geology of Augustine Volcano, Alaska
}

\author{
By Richard B. Waitt and James E. Begét
}

\section{Abstract}

Augustine Island (volcano) in lower Cook Inlet, Alaska, has erupted repeatedly in late-Holocene and historical times. Eruptions typically beget high-energy volcanic processes. Most notable are bouldery debris avalanches containing immense angular clasts shed from summit domes. Coarse deposits of these avalanches form much of Augustine's lower flanks. A new geologic map at 1:25,000 scale depicts these deposits, these processes. We correlate deposits by tephra layers calibrated by many radiocarbon dates.

Augustine Volcano began erupting on the flank of a small island of Jurassic clastic-sedimentary rock before the late Wisconsin glaciation (late Pleistocene). The oldest known effusions ranged from olivine basalt explosively propelled by steam, to highly explosive magmatic eruptions of dacite or rhyodacite shed as pumice flows. Late Wisconsin piedmont glaciers issuing from the mountainous western mainland surrounded the island while dacitic eruptive debris swept down the south volcano flank.

Evidence is scant for eruptions between the late Wisconsin and about 2,200 yr B.P. On a few south-flank inliers, thick stratigraphically low pumiceous pyroclastic-flow and fall deposits probably represent this period from which we have no radiocarbon dates on Augustine Island. Eruptions between about 5,350 and 2,200 yr B.P. we know with certainty by distal tephras. On Shuyak Island $100 \mathrm{~km}$ southeast of Augustine, two distal fall ashes of Augustinian chemical provenance (microprobe analysis of glass) date respectively between about 5,330 and 5,020 yr B.P. and between about 3,620 and 3,360 yr B.P. An Augustine ash along Kamishak Creek $70 \mathrm{~km}$ southwest of Augustine dates between about 3,850 and 3,660 yr B.P. A probably Augustinian ash lying within peat near Homer dates to about 2,275 yr B.P.

From before 2,200 yr B.P. to the present, Augustine eruptive products abundantly mantle the island. During this period, numerous coarse debris avalanches swept beyond Augustine's coast, most recently in A.D. 1883. The decapitated summit after the 1883 eruption, replaced by andesite domes of six eruptions since, shows a general process: collapse of steep summit domes, then the summit regrown by later dome eruptions. The island's stratigraphy is based on six or seven coarse-pumice tephra "marker beds." In upward succession they are layers G $(2,100$ yr B.P.), I (1,700 yr B.P.), H (1,400 yr B.P.), C (1,200-1,000 yr B.P.), M (750 yr B.P.), and B (390 yr B.P.).
A coarse, hummocky debris-avalanche deposit older than about 2,100 yr B.P. - or perhaps a stack of three of themlies along the east coast, the oldest exposed such bouldery diamicts on Augustine Island. Two large debris avalanches swept east and southeast into the sea between about 2,100 and $1,800 \mathrm{yr}$ B.P. A large debris avalanche shed east and eastnortheast into the sea between 1,700 and 14,00 yr B.P.

Between about 1,400 and 1,100 yr B.P. debris avalanches swept into the sea on the volcano's south, southwest, and north-northwest. Pumiceous pyroclastic fans spread to the southeast and southwest, lithic pyroclastic flows and lahars(?) to the south and southeast. Pyroclastic flows, pyroclastic surges, and lahars swept down the west and south flanks between about 1,000 and $750 \mathrm{yr}$ B.P.

A debris avalanche swept into the sea on the west, and a small one on the south-southeast, between about 750 and $400 \mathrm{yr}$ B.P. Large lithic pyroclastic flows shed to the southeast; smaller ones descended existing swales on the southwest and south.

Between about $400 \mathrm{yr}$ B.P. and historical time (late 1770s), three debris avalanches swept into the sea on the west-northwest, north-northwest, and north flanks. One of them (West Island) was large and fast: most of it rode to sea far beyond a former sea cliff, and its surface includes geomorphic evidence of having initiating a tsunami. Augustine's only conspicuous lava flow erupted on the north flank.

During this prehistoric period numerous domes grew at the volcano's summit, remnants of which form the east and south sides of the present summit-dome complex. Three domes grew below the summit area on the upper south and northwest flanks. In between large eruptions that deposited coarse pumiceous fall beds, many smaller eruptions emplaced beds of sand-sized ash on the volcano flanks.

During the past 750 years, beach and back-beach eolian dunes accreted at the southwest coast, forming a ribbed coastwise topography. Lesser dunes grew at the backs of beaches in coves on other flanks.

An eruption in 1883 shed a debris avalanche swiftly into the sea on the north-northeast, followed by pyroclastic flows and surges. Eruptions in 1935 and 1963-64 grew summit domes that spilled over the southwest and south flanks and shed coarse rubbly lithic pyroclastic flows down those flanks. Eruptions and 1976 and 1986 grew domes that draped down 
the north flank and shed voluminous pyroclastic flows to the northeast through north-northwest flanks, when smaller pyroclastic flows and (or) lahars swept down other flanks. A small dome-building eruption in January-March 2006 after this report was all but complete we treat only fleetingly.

The largest debris avalanches sweep into the sea at Augustine's coast at speeds inferred between 60 and $80 \mathrm{~m} / \mathrm{s}$. Augustine is capable of initiating damaging tsunami to lower Cook Inlet, but geologic evidence for them on the mainland is sporadic and sparse.

\section{Introduction}

A very remarkable mountain, rising with a uniform ascent from the shores to its lofty summit, which is nearly perpendicular to the centre of the island.... Towards the seaside it is very low, from whence it rises . . with a rather steep ascent, and forms a lofty, uniform, and conical mountain, presenting nearly the same appearance from every point of view, and clothed with snow and ice, through which neither tree nor shrub were seen to protrude.... - Peter Puget, Chatham, May 1st, 1794

(Vancouver's "Voyage of Discovery”) (Lamb, 1984)
Augustine Island lies in southwestern Cook Inlet, southcentral coastal Alaska, $280 \mathrm{~km}$ southwest of Anchorage (fig. 1A). The nearly circular island of about $90 \mathrm{~km}^{2}$ is $12 \mathrm{~km}$ wide east-west, $10 \mathrm{~km}$ north-south. A nearly symmetrical central summit-Augustine Volcano - peaks at altitude 1,254 m (figs.1B, 2, and 3). ${ }^{1}$ The volcano lies along an active segment of the eastern

1 "Discovered" during Capt. James Cook's 3rd Voyage of Discovery on 26 May 1778. In England this being St. Augustine's Day, the name became Mount St. Augustín (Beaglehole, 1967). (Outside Britain, St. Augustine's feast day is the 28th not 26th of May.) The saint commemorated is the British Augustine - the late 6th-c. and early 7th-c. Augustine of Cantebury-not the famous literary early 5 th-c. doctor of Christianity, Augustine of Hippo. Within a few days Cook distinguished Mount St. Augustine as also an island, not a peninsula, and charted it "St. Augustín Island."

The next British voyage, a commercial one by Portlock and Dixon (two of Cook's 1778 officers) called the mountain by Cook's name "Mount St. Augustine" in July and August 1786. Dixon's 24 December 1788 chart labels the peak "Mt. St. Augustine." Cook's name is also accepted in Vancouver's 1794 narrative ("Mount St. Augustin" and "the island of St. Augustin"). Meanwhile in late 18th and early 19th centuries the Russian explorers and traders had called it "Chernoburoy" (=black-brown mountain), a name abandoned once Alaska became United States territory in 1867.

Dall (1884) called it Augustin Island; Davidson (1884) called it Mount St. Augustine; Becker (1898) called it Mount St. Augustine and St. Augustine Volcano; Coats (1950, p. 44) simplified it to Augustine Volcano, but Forbes and Kienle (1971) and Jürgen Kienle's many papers in the 1970s and 1980s

Figure 1. Index maps. $A$, Cook Inlet area, Alaska; volcanoes shown by triangles, towns by dots; Augustine Volcano constitutes most of Augustine Island. $B$, Augustine Island; surveyed benchmarks shown by solid circles; four of them-Grouse, Burr, Mound, Kamishak-define now-common place names.

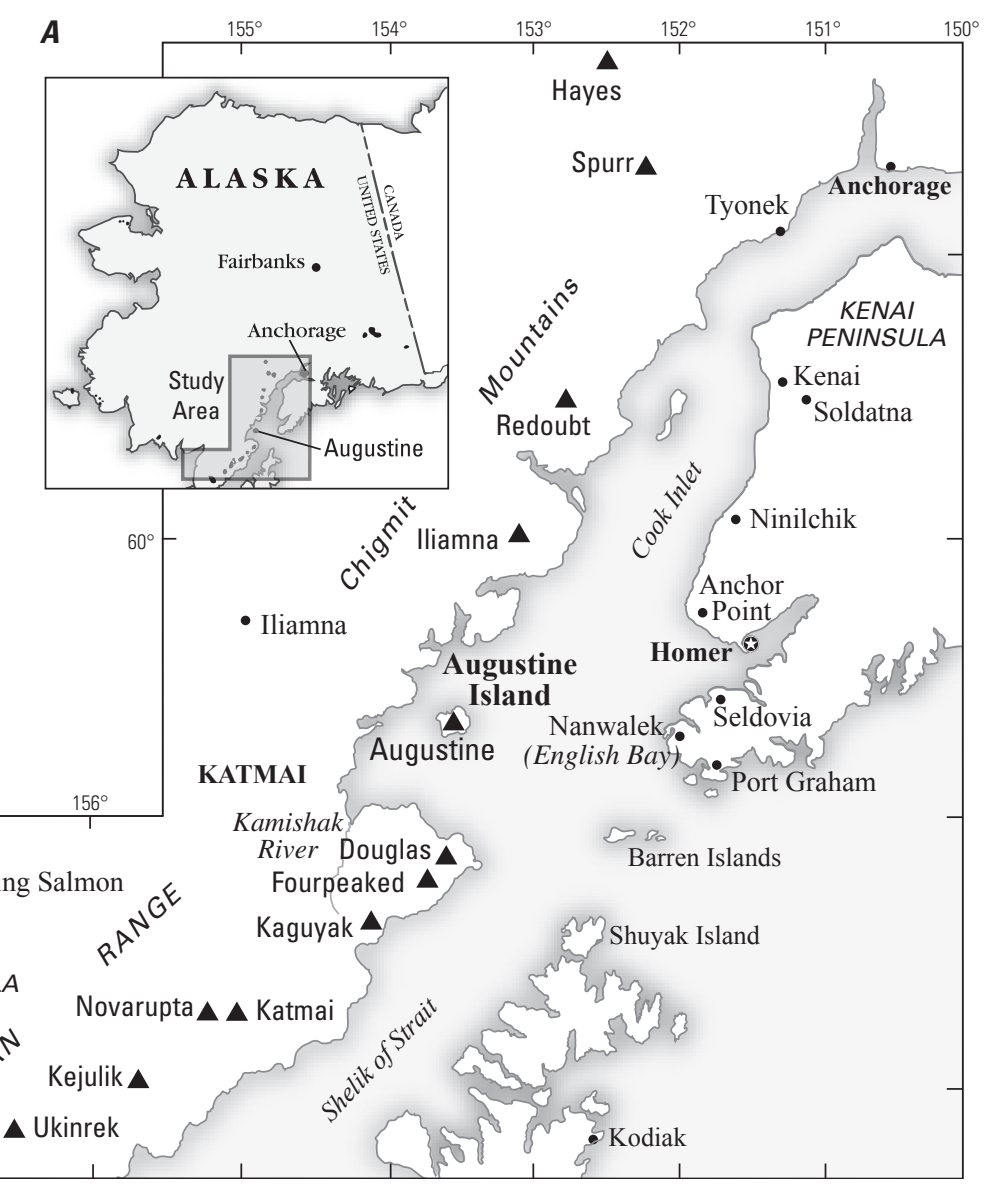


Aleutian arc and 90-140 km above a seismic Benioff zone (Kienle and Forbes, 1976, fig. 6; Kienle and Swanson, 1983a, fig. 8). Augustine is the region's most explosive and frequently erupting volcano. It has erupted countless times since the end of the last ice age (since about 15,000 radiocarbon years ago [Hamilton and Thorson, 1983]) including six historical eruptions: 1812, 1883, 1935, 1963-64, 1976, and 1986 - and now a small 7th eruption in 2006.

In the 1940s-1950s there had been a small pumicemining operation on the lower west flanks and a barge-loading ramp on West Lagoon. The ramp and bulldozer tracks, parts of which still exist, are plotted on plate 1 from airphotos and extracted from Detterman's (1973) map.

From 1990 aerial photographs, the U.S. Geological Survey (USGS) National Mapping Division scribed a new topographic map of Augustine Island at 1:25,000 scale with a $10-\mathrm{m}$ contour interval. On this new base we plot a new

clung to the earlier version: "Mount St. Augustine." To this day it's sometimes written and spoken as "Mount St. Augustine" - even if not on USGS maps, which print only Augustine Island and Augustine Volcano. Today the mountain - the whole edifice - is usually called Augustine Volcano or just plain "Augustine." "Mount Augustine," though still sometimes used, has not been formalized by the U.S. Board of Geographic Names (see Orth, 1967). geologic map (plate 1). We mapped rocks and deposits of Augustine Island during eight brief field sessions between 1988 and 1997, plotting field data on vertical 9-by-9-inch aerial photographs taken in August 1990. We distinguish some look-alike deposits of the 1976 and 1986 eruptions having similar distributions by comparing the 1986 and 1990 aerial photographs with others of August 1976. Some deposits of 1963-64 eruption are distinguished from those of 1935 by aerial photographs of July 1957 . With an analog Kern PG-2 stereoplotter outfitted with an automatic plotting table, Waitt in 1995-96 compiled the field-mapped geology from the aerial photographs to the topographic map. A provisional version of this topographic and geologic map is published uncolored (Waitt and Beget, 1996).

In 1998 the topographic and revised geologic sheets were scanned into GIS (Arc/Info) format by Jacqueline McIntire and Steve Schilling, proofed and corrected by Waitt and McIntire. The digital map can be readily altered in the future-for instance in areas affected by the 2006 eruption and any future ones-without having to redo the entire map.

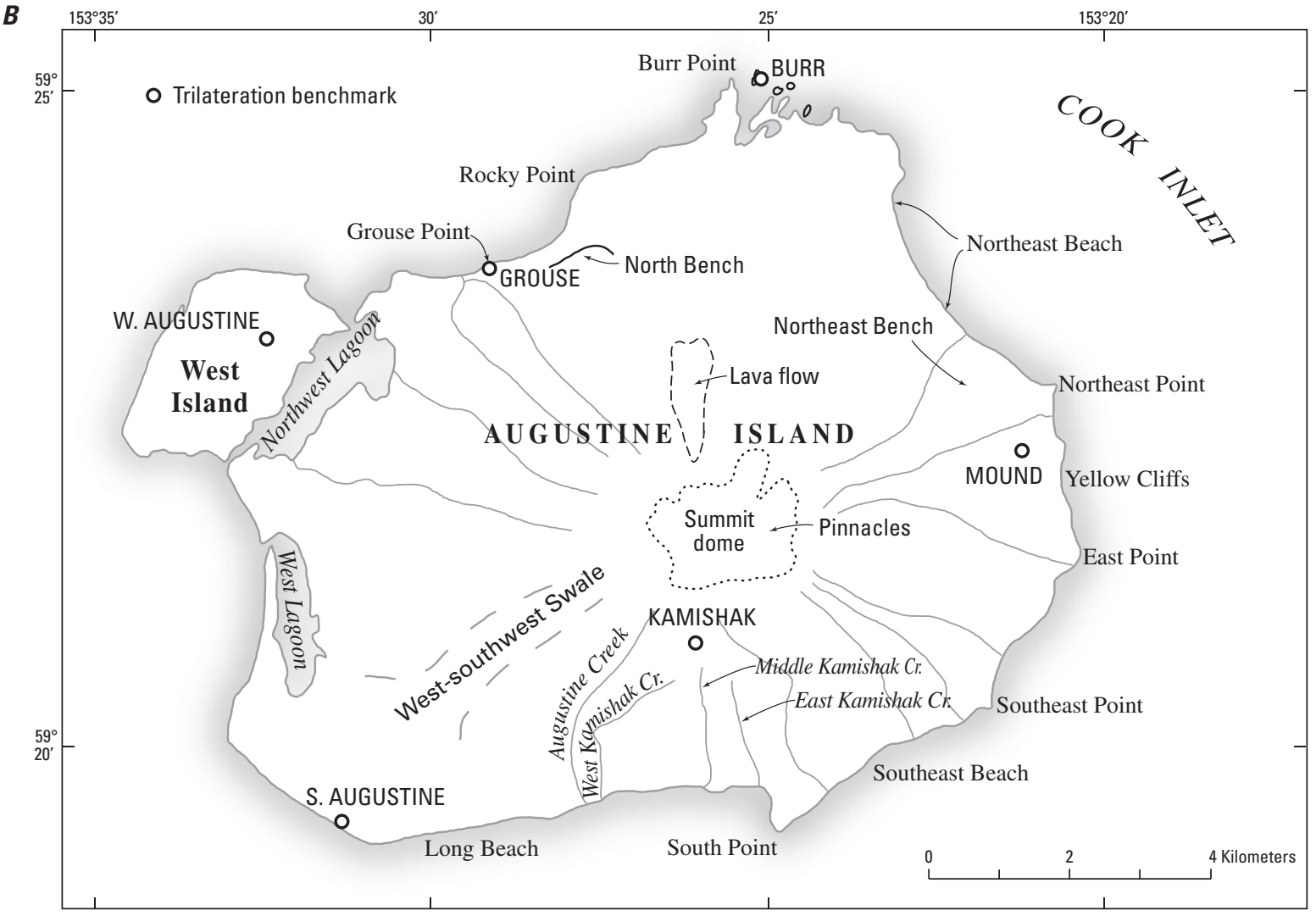

NOTE: All places names associated with Augustine are informal with the exception of Burr Point, Augustine Creek, Augustine Island, and Augustine Volcano.

Figure 1.-Continued 


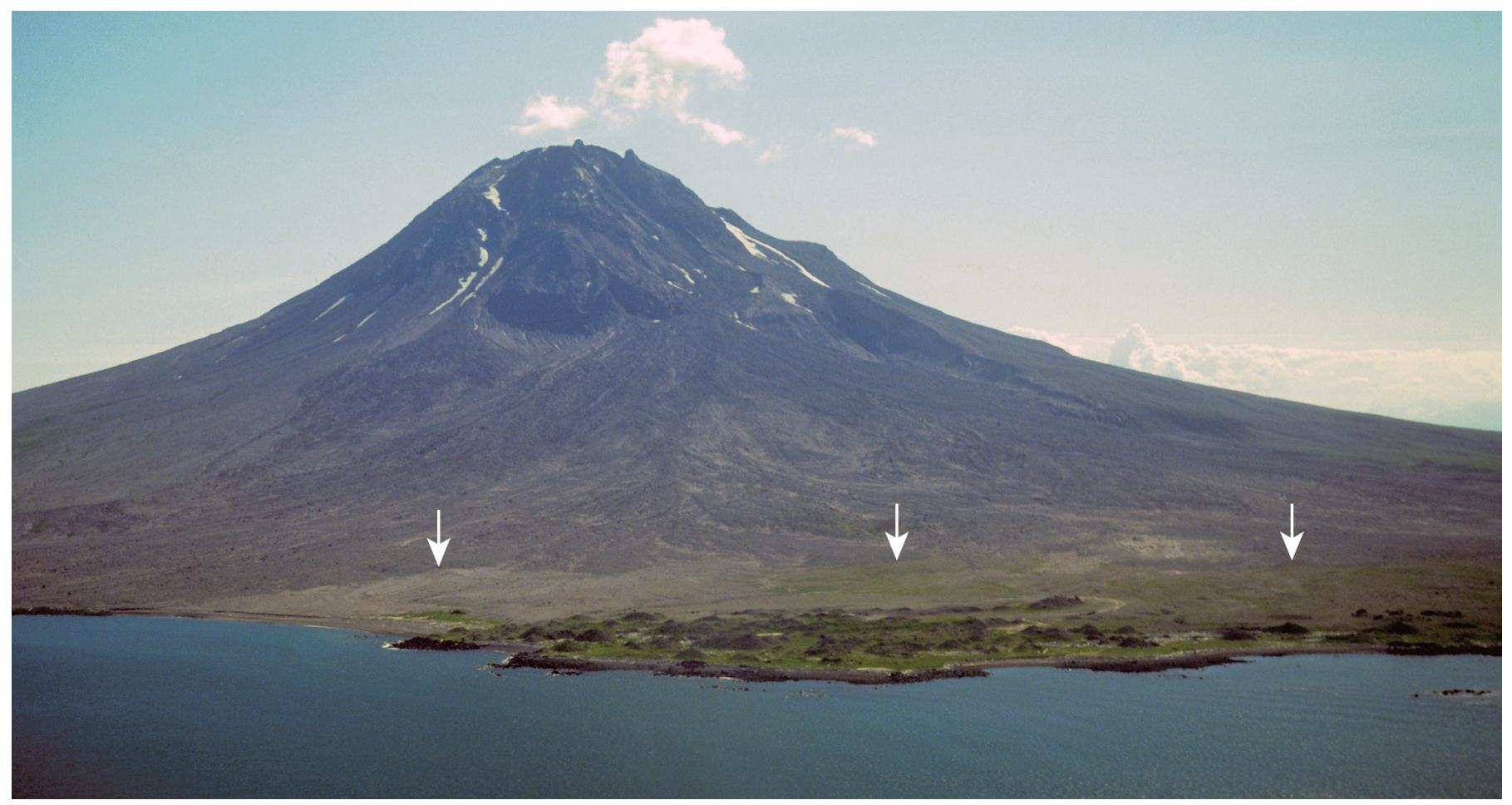

Figure 2. View south-southwest of Augustine Volcano, Alaska. Hummocky coastal debris in foreground is deposit of debris avalanche that removed summit of volcano at start of 1883 eruption, overrode a coastal cliff (arrows), and flowed into the sea. Five subsequent dome-building eruptions $(1883,1935,1963-64,1976,1986)$ have restored summit to its pre-1883 height and steepness. (USGS photograph by Richard Waitt, July 1990.)

\section{Landslide}

Augustine's summit consists of several overlapping domes and marginal breccias emplaced during many prehistoric and historical eruptions. Most fragmental debris in coastal exposures are coarse diamicts comprising angular blocks of dome-rock andesite typically of cobble to boulder size but carrying clasts as large as 4 to $8 \mathrm{~m}$, rarely as large as $30 \mathrm{~m}$ - all set in a sandy matrix full of finer very angular fragments. The surface of such deposits is hummocky, a field of steep conical mounds and intervening depressions with many meters of local relief.

During a brief 1913 visit, Robert Griggs inferred landslide (debris avalanche) ${ }^{2}$ as the origin of Augustine's hummocky coastal topography about Burr Point (fig. 2), which he later thought analogous with the hummocky and blocky deposit of the 1912 Mageik landslide at nearby Katmai (Griggs, 1920, p. 341). Several other reports noted hum-

\footnotetext{
${ }^{2}$ Large landslides off volcanoes are commonly called "debris avalanches," like that which started the cataclysmic Mount St. Helens eruption on 18 May 1980 (Voight and others, 1981). Similar processes and their deposits in nonvolcanic terrain are usually called "landslides." At Augustine, we distinguish "slide," which describes the beginning of the process on the upper slopes of a volcano when the detached block is still intact, from "avalanche," which describes the process once the block has broken up and its fragments are complexly sliding and tumbling down the lower slopes of the volcano. The final deposit is thus called a "debris-avalanche deposit."
}

mocky, coarse deposits on the flanks of several Pacific volcanoes: Bandai-san and Yatsugatake in Japan, Galunggung and Raung in Indonesia, and Ruapehu, Egmont, and White Island in New Zealand. Such deposits had been inferred to originate suddenly by landslide or "lahar" and were summarized and discussed in textbooks (Cotton, 1944, p. 247-253; Macdonald, 1972, p. 180). Catastrophic nonvolcanic landslides in mountain valleys - at Elm, Switzerland, in 1881; at Frank, Alberta, in 1903; at Gros Ventre valley, Wyoming, in 1925had also formed coarse blocky deposits with similarly hummocky topography. A gigantic $\left(20 \mathrm{~km}^{3}\right)$ prehistoric endmember at Saidmarreh valley, Iran, became known and discussed (Harrison and Falcon, 1937, 1938; Oberlander, 1965, p. 61-62, 155-156). These phenomena figured in syntheses and in geomorphology textbooks (Sharpe, 1938, plates 1 and 8; Thornbury, 1954, p. 90-93). But unaware of Griggs's (1920) obscure paragraph and unattuned to geomorphic literature, students of Augustine in the 1960s-1970s did not include large landslide among the volcano's seminal processes (Detterman, 1973; Johnston, 1978; Kienle and Swanson, 1980).

The hummocky deposits on Augustine's lower flanks mimic topographically and lithologically those of the great landslide or debris avalanche that initiated the spectacular 18 May 1980 eruption of Mount St. Helens in Washington (Voight, 1981; Voight and others, 1981, 1983; Glicken, 1991, 1996, 1998). The deposit of that landslide revealed to all the origin of coarse diamicts with hummocky topography at 
Table 1. Summary of previous geologic work bearing on description of rocks and deposits at Augustine Volcano.

[Note: Table excludes recent reports, such as those on geophysical monitoring and petrology, especially after 2003]

Reference Topic

\begin{tabular}{|c|c|}
\hline Dall, 1884 & Brief summary of observed effects of 6 October 1883 Augustine eruption \\
\hline Davidson, 1884 & Summary of observed effects of 6 October 1883 Augustine eruption \\
\hline $\begin{array}{l}\text { G.E., Davidson, (unpub. letter } 6 \\
\text { Nov. 1884) }\end{array}$ & $\begin{array}{l}\text { Relates direct observation in June } 1884 \text { by a Capt. Cullie that N. flank Augustine slid as cataclysmic land- } \\
\text { slide into sea on } 6 \text { Oct. } 1883\end{array}$ \\
\hline Becker, 1898 & Direct observations of flanks and crater in 1895 , after 1883 eruption \\
\hline Dall, 1918 & Includes brief reminiscence of 1895 Augustine visit with Becker \\
\hline Detterman and Reed, 1964 & Geologic map at 1:250,000 including Augustine Island (generalized) \\
\hline Detterman, 1968 & Summary of observed effects of 1963-64 Augustine eruption \\
\hline Forbes and Kienle, 1971 & Popular summary of historical observations from Cook's voyage to 1964 eruption \\
\hline Detterman, 1973 & Geologic map at 1:63,360 of Augustine Island \\
\hline $\begin{array}{l}\text { D. Johnston, J. Kienle, J. Whitney, } \\
\sim 1978\end{array}$ & $\begin{array}{l}\text { "Hazards of Augustine Volcano, Alaska" (90 p. } 32 \text { figs.) — a detailed report, unpublished, but a major } \\
\text { resource for Kienle and Swanson, } 1980 \text { [1985] }\end{array}$ \\
\hline Johnston, 1979 & Evidence that Augustine volcanism began during the late Pleistocene \\
\hline Johnston and Detterman, 1979 & Summary of historical eruptions; deletion of spurious "1902 eruption" \\
\hline $\begin{array}{l}\text { Kienle and Swanson, } 1980 \\
\quad \text { [reprinted 1985] }\end{array}$ & History of Augustine Volcano; volcano hazards (mostly pyroclastic flow, lahar, and dome growth) \\
\hline
\end{tabular}

Kienle and Swanson, 1983a Plate-tectonic setting and petrology, including Augustine

Kienle and Swanson, 1983b Revised (from Kienle and Swanson, 1980) hazard assessment of Augustine; adds concept that Mount-St.Helens-like debris avalanches repeatedly reached the sea

Siebert, 1984 Documentation of Mount-St.-Helens-type debris avalanches off many volcanoes, including Augustine

Kienle, Davies, Miller, Yount, 1986 Summary of chronology and observed effects of 1986 Augustine eruption

Daley, 1986

Reeder and Lahr, 1987

Yount, Miller, and Gamble, 1987

Siebert, Glicken, Ui, 1987

Kienle, Kowalik, and Murty, 1987

Swanson and Kienle, 1988

Siebert, Glicken, and Kienle, 1989

Kamata, Johnston, and Waitt, 1991

Begét and Kienle, 1992

Siebert, Begét, and Glicken, 1995

Waitt and Begét, 1996

Waythomas and Waitt, 1998

Power and others, 2006

Begét and others, 2008
Petrology, petrography, geochemistry of Augustine domes and lava flows

Seismic evidence for behavior and timing of Augustine 1976 eruption

Summary processes and effects of 1986 eruption

Debris avalanches and consequent lateral blasts and tsunami at many volcanoes, including Augustine

Numerical simulation of 1883 Augustine tsunami

Comparison of 1986 Augustine eruption of pyroclasitc flows and dome growth with hazards report of Kienle and Swanson (1980); occurrence of a debris avalanche, though unlikely, a concern during 1986 eruption

Concept of debris avalanche forming flanks of Augustine Volcano; details on prehistoric West Island and 1883 Burr Point debris avalanches

1976 eruption chronology, effects, deposits, and stratigraphy of north flank

Tephra- and ${ }^{14} \mathrm{C}$-dated 12 Augustine debris avalanches in last $2,000 \mathrm{yr}$; early deposits $>40,000$ yrs

Details of debris-avalanche deposits on north flank

Provisional version of present report; map uncolored; revisions to Begét and Kienle (1992) and to Siebert and others (1995)

Provisional assessment of hazards from Augustine Volcano

Summary of 2006 eruption

Evidence of Augustine tsunami on mainland coasts 


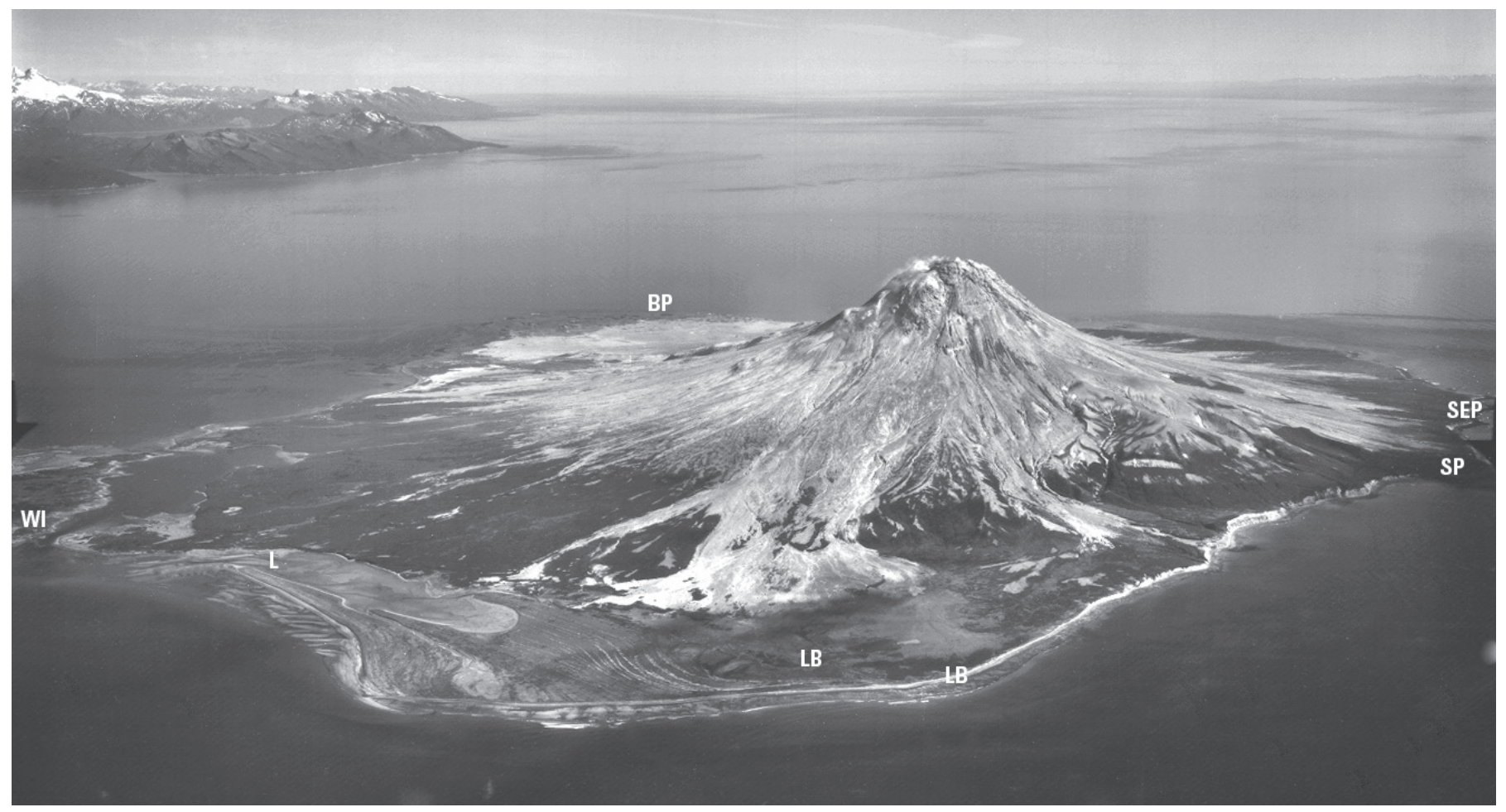

Figure 3. View northeast of Augustine Island and Augustine Volcano. Much of vegetated (dark-toned) area of lower flanks is debrisavalanche deposits: BP, Burr Point; WI, West Island; L, West Lagoon; SP, South Point; LB, Long Beach; SEP, Southeast Point. Light-toned areas are deposits of pyroclastic flows of 1963-64, 1976, and 1986 eruptions. (USGS photograph by Austin Post, 25 August 1987.)

the bases of other stratovolcanoes. And so since 1980 many hummocky, coarsely fragmental deposits on Augustine's lower flanks have been reinterpreted as deposits of numerous great landslides and debris avalanches (Kienle and Swanson, 1983b; Siebert and others, 1989; Begét and Kienle, 1992; Waitt and Begét, 1996).

Table 1 summarizes themes of geologic reports about Augustine Island volcano that precede this report and map.

\section{Lava-Dome Effusion Rates}

Estimating cumulative volumes of historical domes and of Augustine's prehistoric debris-avalanche deposits, Begét and Kienle (1992) calculated a long-term lava-dome effusion rate of 1-3 million $\mathrm{m}^{3} / \mathrm{yr}$. Such rates are 10 to 100 times greater than typical effusion rates for calc-alkaline volcanoes in subduction zones (Crisp, 1984). The present report elaborates summaries such as Begét and Kienle (1992), but our current list and analysis of radiocarbon dates do not much alter the earlier generality. During the late Holocene, Augustine Volcano has sustained one of the highest rates of magma effusion from a subduction zone. This is probably why Augustine's summit area is unusually prone to fail by landslide.

\section{Rock Type, Grain Size, Grain Shape}

In hand specimen and thin section, the dome and lavaflow rocks of Augustine Volcano are plagioclase-porphyritic andesite (rarely dacite) ranging from dark gray to light gray to reddish (oxidized). Deposits of debris avalanches, debris flows, and pyroclastic flows consist of or contain boulders and smaller fragments of gray to reddish porphyritic andesite. To the eye the lithic fragmental deposits are all more or less alike, all more or less identical to summit-dome rocks. Some of the pyroclastic flows and all the coarse fall layers are rich in white to cream to pale-gray pumice. On the south volcano flank are rare inliers of fragmental olivine basalt.

In hand specimen and thin section the "lithic" clasts of andesite contain 20 to 50 percent phenocrysts, mostly plagioclase but including hypersthene, augite, iron-titanium oxides, and traces of olivine, apatite, and opaque minerals. Johnston (1978) describes microscopic details of 1976 eruption products. Daley (1986, appendix II) describes petrographic details of various domes, lava flows, and rubble flows.

Chemically analyzed Augustine rocks scatter across the $\mathrm{SiO}_{2}$ field of andesite of LeBas and Streckeisen (1991, fig. 5) (fig. 4). A few analyzed whole-rock samples range down into the basaltic-andesite field or up to the dacite field. The glass fraction of pumice fragments ranges from dacite to rhyolite. For each of six coarse pumice layers of the past 2,000 years 
as well as for some older layers, the most silicic of the glass analyses are well into the rhyolite range (above 72 percent $\mathrm{SiO}_{2}$ ). Most of the glass-separate data from various tephrapumice layers $\left(\mathrm{SiO}_{2}\right.$ above 65 percent) are unpublished. Begét in 1989 analyzed 20 tephra samples with a microprobe at Washington State University, and James R. Riehle and Charles E. Meyer analyzed 68 samples with the microprobe at the USGS in Menlo Park in 1995 (for example, Riehle and others, 1998).

Petrologic studies show that neither mineralogically nor chemically have Augustine rocks varied much through thousands of years including successive historical eruptions (Kienle and Swanson, 1980, p. 69-72; Daley, 1986). Each eruption seems to emit a similar suite of porphyritic andesite, some ranging up to dacite. By far the most intensely studied suite of deposits is of the 1976 eruption: Johnston (1978) makes the case for intrusion of basalt into a dacite magma chamber, where the two were partly mixed before erupting. Clasts of variegated "mixed-magma" pumice lie among the pumicous deposits of several eruptions.

Many deposits at Augustine Volcano are to some degree pyroclastic in origin, but also they are sediments. As in field studies of other volcanoes (for example, Waitt, 1981; Waitt and others, 1994), at Augustine one needs a grain-size designation for each phi (grain-size) interval between silt and cobble size to apply commonly to various pyroclastic, landslide, laharic, waterlaid, beach, and eolian deposits and to some deposits of ambiguous origin. Pyroclastic size terms like ash, lapilli, blocks (Schmid, 1981) are far too-little subdivided for these purposes. For instance, "coarse ash" comprises fully five size intervals that are routinely distinguished by hand-lens in the field ( -1 through +4 phi, very coarse sand through very fine sand). Standard sedimentologic (Wentworth, 1922) size terms are usefully divided. The universally used "Wentworth" terms for nonpyroclastic sediments are unambiguous and avoid our inventing an ad hoc and strange modification of pyroclastic size terms-say "fine coarse ash" for a pyroclastic-fall deposit of median grain size 2 to 3 phi ( 0.5 to $0.125 \mathrm{~mm})$.

Grain sizes are determined in the field by comparing a sample to Wentworth size standards, and named as by Folk $(1954 ; 1974,1980)$. Thus a designation such as "pebbly sand" denotes grain size solely, raw description with no implication whatever to genesis or emplacement process. Though provincial pyroclastic grainsize terms like "ash" and "lapilli" deserve to be abandoned, for old-times' sake we in places substitute a pyroclastic noun for the sedimentologic one where it seems appropriate and is not confusing. Thus to avoid the term "gravel" in defining a pumiceous fall deposit, we say "medium-pebble pumice" instead of "medium-pebble

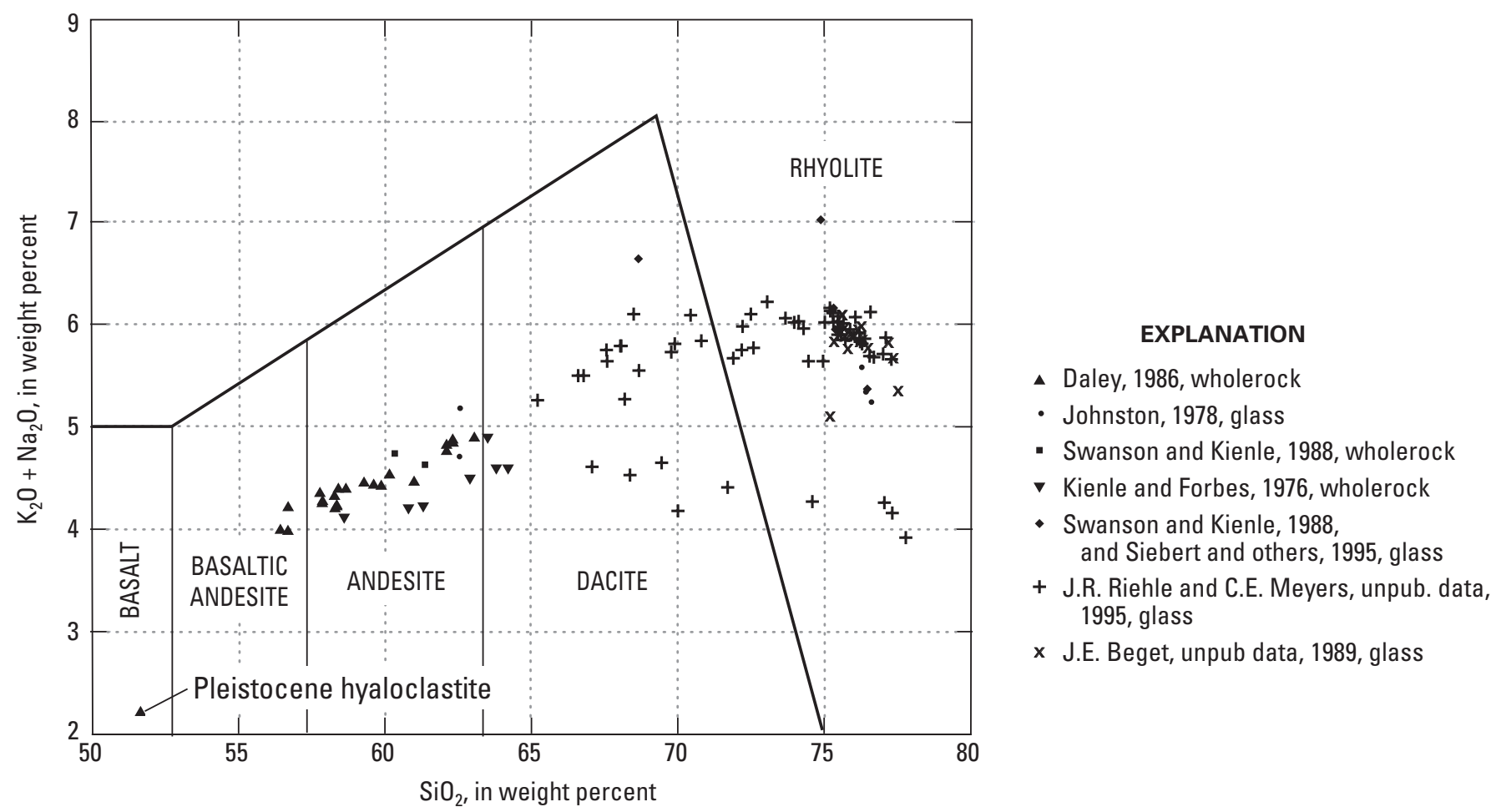

Figure 4. Plot of chemical composition analyses of volcanic rocks (whole-rock analyses) and tephra (glass-separate analyses) from Augustine Island, Alaska. The glass analyses are from the six coarse coastal pumice-tephra layers, from older tephras on nunatak-like inliers, and from historical eruptions in 1963, 1976, and 1986. Glass analyses done by microprobe, each point representing the mean of values counted for 10-18 shards. Fields named according to LeBas and Streckeisen (1991, fig. 5). 
gravel"; to avoid calling as simply descriptive "silt" what is clearly a fall ash, we say "silt ash."

Clast roundness, designated in terms like "very angular" and "subrounded" we estimate in the field from the visual standards of Powers (1953).

\section{Chronology}

\section{Radiocarbon Ages}

We obtained a few dozen radiocarbon ages from organic materials interbedded with tephra deposits on Augustine Island or with Augustine tephras at a few distal sites (table 2). In a layered sequence, a dated organic sample from just above a tephra gives a minimum-limiting age of that tephra; one from just below gives its maximum-limiting age. Most radiocarbon ages directly limit the age of tephra layers. Once age-bracketed by radiocarbon dates, a distinguishable tephra layer becomes a useful date by proxy. Table 3 depicts a generalized composite stratigraphy of Augustine's debris-avalanche deposits relative to the main tephra deposits.

The radiocarbon timescale is unsteady because ${ }^{14} \mathrm{C}$ activity in atmospheric $\mathrm{CO}_{2}$ has varied through time. High-precision calibrating, as by dating a single tree ring of known age, accord radiocarbon time closely with calendar time (Stuiver, 1982; Stuiver and Pearson, 1993). Such analyses with improvements over the years allows routine high-precision calibration of radiocarbon dates by using computer programs "CALIB" (Stuiver and Reimer, 1993; Stuiver and others, 1998) and "OxCal" (Bronk Ramsey 1998, 2000, 2001). The 53 Augustine radiocarbon dates are calibrated (col. 3 of table 2) by OxCal (v. 4, 2006), which can be run online at http://c14.arch.ox.ac.uk/. Similar results had been obtained from CALIB (v. 4.2, 2000) currently available (v. 5, 2005) at http://calib.qub.ac.uk/calib (Stuiver, Reimer, and Reimer, 2005).

The stratigraphy and geologic history in this report of Augustine Volcano is timed by the raw radiocarbon scale (uncalibrated). An expression like "about 1,700 years ago" implies radiocarbon $\left({ }^{14} \mathrm{C}\right)$ time (table 2, col. 1). But the calibrated ages for each date allow one to tell more precisely how long between one event and another. Raw radiocarbon ages between about 300 and 2,500 yr B.P. are generally "older" than in calibrated (calendar) time. Raw ${ }^{14} \mathrm{C}$ ages older than about $2,500 \mathrm{yr}$ B.P. are generally "younger" than their calibrated times. Thus a raw radiocarbon age of about $6,500 \mathrm{yr}$ B.P. is roughly 7,400 yr B.P. in calibrated (calendar) time.

\section{Tephra and Tephrochronology}

Tephra blankets parts of Augustine's flanks and veneers mainland areas far downwind. Wind data for a 14-year period (fig. 5) show that in lower Cook Inlet average annual wind is eastward about 80 percent of the time, westward about 20 percent. Only about 10 percent of the time is wind toward the 90-degree arc between northwest and southwest. The prevailing winds govern directions toward which tephra tends to drift from Augustine. Indeed during Augustine's 1986 explosive phase of eruption, ash blew to the northeast, east, southeast, and south (Yount and others, 1987, fig. 8).

Tephra sequences 1 - to 3.5 -m thick are fairly continuous along the east, southeast, and south coasts of Augustine Island, which are the generally downwind azimuths where tephra should tend to accumulate. But also these lower flanks are where many flowage deposits are older than on other flanks, and thus older tephras are preserved here more than elsewhere. Upper Holocene stratigraphy established in these most complete sections shows six coarse pumiceous layers stratigraphically superposed, separated by peat, fine (sand or silt) tephra layers and in places eolian sand. In upward stratigraphic order (fig. 6; tables 2 and 3) the coarse tephra layers we designate as tephras G (2,100 yr B.P.), I (1,700 yr B.P.), H (1,500-1,400 yr B.P.), C (1,200-1,000 yr B.P.), M (750 yr B.P.), and B (390 yr B.P.). Between tephras $\mathrm{C}$ and $\mathrm{M}$ a seventh tephra $\mathrm{O}$-rare and in most places missing, its origin and significance obscure - we eventually dropped as a reliable marker bed but it shows in certain measured sections (plate 2). These coarse tephra layers also contain 10 to 40 volume percent lithic andesite fragments smaller than pumice fragments. Isopach maps, drawn from thickness measured mostly at coastal exposures, show the azimuths to which five of the coarse layers drifted (fig. 7).

The lowest five coarse-pumice beds at the coast-tephras G, I, H, C, and O-drifted east and southeast. Tephra G and ambiguous tephra $\mathrm{O}$ are known only from a few sites each on the east and southeast, neither with enough data points to warrant a map. Drawn from data at many stratigraphic exposures, isopach maps clearly show tephras I, H, and C drifted eastsoutheast and southeast. Of the two youngest coarse tephras, $\mathrm{M}$ drifted south and B strongly northeast (fig. 7). All these azimuths - northeast, east, southeast, south - are among the common directions of modern winds (fig. 5).

Between the coarse pumiceous layers are numerous layers of sand and silt ash, volumetrically much of any one fall section but not useful for correlating between sites. Within a few scattered inlier sections of older debris lie several additional coarse tephra layers that are not readily correlated from place to place. Some are surely older than coastal tephra G.

In 1989 Begét, and in 1995 James R. Riehle and Charles E. Meyer (written commun., 1995), analyzed by microprobe for eight major elements in glass from many samples of Augustine proximal pumiceous tephra. These data support many of the correlations within $1 \mathrm{~km}$ of the coast based on field stratigraphy, and they suggest correlations with upper parts of some of the inlier sections farther inland. But they also show that several superimposed tephras are chemically heterogeneous and that some of their compositional ranges overlap. Glass separates of tephras $\mathrm{C}$ and $\mathrm{M}$ are chemically nearly identical-as close as replicate microprobe analyses of either tephra $\mathrm{C}$ or tephra $\mathrm{M}$ alone. Correlation of tephras between separated localities is thus mainly by field stratigraphy, in some places strengthened or augmented by the microprobe data. 
Table 2. Radiocarbon ages and stratigraphy of tephra layers at Augustine Volcano.

\begin{tabular}{|c|c|c|c|c|c|c|}
\hline $\begin{array}{l}\text { Ages (tephra) } \\
\left({ }^{14} \mathrm{C} \text { yr B.P.) }{ }^{1}\right.\end{array}$ & Lab. No. & $\begin{array}{c}\text { Calibrated } \\
\text { Ages }^{1} \\
\text { (Calendar yr } \\
\text { B.P.) }\end{array}$ & Material & Overlain by & Underlain by & Reference $^{2}$ \\
\hline $\begin{array}{l}50 \pm 50^{3} \\
\quad(\text { modern })\end{array}$ & B-117198 & $269-13$ & Wood $(\log )$ & $\begin{array}{l}\text { Lies within Augustine-tsunami? gravelly sand } \\
\text { (distal, at Red River delta) }\end{array}$ & $\begin{array}{l}\text { Lies within Augustine-tsunami? gravelly } \\
\text { sand (distal site) }\end{array}$ & This study, A99 \\
\hline $\begin{array}{l}80 \pm 80^{3} \\
\quad(\text { modern })\end{array}$ & B-117199 & $283--4$ & Wood $(\log )$ & $\begin{array}{l}\text { Lies within Augustine-tsunami? gravelly sand } \\
\text { (distal, at Red River delta) }\end{array}$ & $\begin{array}{l}\text { Lies within Augustine-tsunami? gravelly } \\
\text { sand (distal site) }\end{array}$ & This study, A99 \\
\hline $\begin{array}{l}101.7 \pm 0.7 \% \\
\quad(\text { modern })\end{array}$ & B-55672 & $254-32$ & Peat & Katmai-1912 ash and two older ashes & Grouse Point debris-avalanche deposit & This study \\
\hline \pm 185 (modern) & I-14992 & $\pm 285--3$ & Peat & Pyroclastic ash unknown age & 1883 debris-avalanche hummock & BK92 \\
\hline \pm 285 (modern) & I-14923 & $\pm 422-301$ & Soil & Pyroclastic ash unknown age & Peat of previous date & BK92 \\
\hline $140 \pm 60$ & B-24773 & $285--1$ & Willow branch & Fan deposit & Fan deposit & BK92 \\
\hline $170 \pm 70$ & B-24779 & $418--4$ & Soil & Silt below modern soil & $\begin{array}{l}\text { Hummock of Rocky Point debris-ava- } \\
\text { lanche deposit }\end{array}$ & BK92 \\
\hline $195 \pm 115$ & $?$ & $416--4$ & Soil & Ash (pre-1883?) $30 \mathrm{~cm}$ below Katmai 1912 ash & Tephra B, $10 \mathrm{~cm}$ downsection & SK88 \\
\hline $205 \pm 90$ & I-14924 & $455--4$ & Organic layer & Sand ash below Katmai 1912 ash & $\begin{array}{l}\text { Sand over West Island debris-avalanche } \\
\text { deposit }\end{array}$ & BK92 \\
\hline $280 \pm 100$ & B-24781 & $511--3$ & Organic layer & $40 \mathrm{~cm}$ ash below Katmai 1912 ash & Tephra B lapilli pumice & BK92 \\
\hline $330 \pm 145$ & $?$ & $623--3$ & Soil & Soil of 195 yr B.P. age & Tephra B & SK88 \\
\hline $367 \pm 55$ & $?$ & $505-310$ & $\begin{array}{l}\text { Uncharred } \\
\text { alder bark }\end{array}$ & $\begin{array}{l}\text { "Blast" deposit atop West Island debris-avalanche } \\
\text { deposit }\end{array}$ & West Island debris-avalanche deposit & SGK89 \\
\hline $380 \pm 20$ & QL-4808 & $504-328$ & Bulk peat & Lahar deposit and ash below Katmai 1912 ash & Tephra B & This study \\
\hline \multicolumn{7}{|c|}{ Tephra B } \\
\hline $400 \pm 50$ & B-55673 & $522-316$ & $\begin{array}{l}\text { Dense organic } \\
\text { layer }\end{array}$ & Tephra B(?) & Eolian sand & This study \\
\hline $410 \pm 50$ & B-24777 & $530-316$ & Soil layer & Pumice layer B(?) & Pumice layer (M?) & BK92 \\
\hline $450 \pm 80$ & B-28536 & $635-309$ & $\begin{array}{l}\text { Soil between } \\
\text { pumice layers }\end{array}$ & Pumice layer (B?) $19 \mathrm{~cm}$ higher & $\begin{array}{l}\text { Pumice layer (M?) directly below; farther } \\
\text { down Tephra C }\end{array}$ & BK92 \\
\hline $470 \pm 140$ & $?$ & $694--2$ & Soil & Tephra B directly & Tephra M directly & SK88 \\
\hline $490 \pm 70$ & B-24776 & $654-325$ & Soil & Tephra B $15 \mathrm{~cm}$ up & Tephra M? directly below & BK92 \\
\hline $710 \pm 50$ & B-55667 & $732-558$ & Organic layer & Pumice layer (B?) & Pumice bed (M?) & This study \\
\hline $730 \pm 60$ & B-28537 & $779-557$ & Soil & $41 \mathrm{~cm}$ of ash and soil capped by lithic ash (1883?) & Tephra B? or M? & BK92 \\
\hline \multicolumn{7}{|c|}{ Tephra M } \\
\hline $760 \pm 60$ & B-55662 & $891-561$ & Peat & Tephra M directly & Tephra C, $1.5 \mathrm{~m}$ downsection & This study \\
\hline $770 \pm 50$ & $?$ & $790-653$ & Peat & Tephra M directly & Tephra C, $1 \mathrm{~m}$ downsection & BK92 \\
\hline $800 \pm 60$ & B-55664 & $905-657$ & $\begin{array}{l}\text { Top } 8 \mathrm{~cm} \text { of } \\
\text { organic layer }\end{array}$ & Tephra M directly & Lithic pyroclastic-flow deposit & This study \\
\hline $800 \pm 120$ & ? (beget) & $936-548$ & Soil & Tephra M directly & Tephra C, $10 \mathrm{~cm}$ downsection & SK88 \\
\hline
\end{tabular}




\begin{tabular}{|c|c|c|c|c|c|c|}
\hline $\begin{array}{l}\text { Ages (tephra) } \\
\left({ }^{14} \mathrm{C} \text { yr B.P.) }{ }^{1}\right.\end{array}$ & Lab. No. & $\begin{array}{l}\text { Calibrated } \\
\text { Ages }^{1} \\
\text { (Calendar yr } \\
\text { B.P.) }\end{array}$ & Material & Overlain by & Underlain by & Reference $^{2}$ \\
\hline $860 \pm 80$ & B-24780 & $925-675$ & $\begin{array}{l}\text { Willow wood } \\
\text { uncharred }\end{array}$ & Rockfall $\backslash$ pumiceous pyroclastic flow $\backslash$ Tephra M & Pumiceous pyroclastic flow $\backslash$ rockfall & BK92 \\
\hline $1,000 \pm 100$ & B-24780 & $1,169-725$ & Soil & Silt beneath tephra M & Alluvium atop tephra $\mathrm{C}$ & BK92 \\
\hline $1,110 \pm 70$ & B--58976 & $1,063-745$ & charcoal and soil & Debris flow & Tephra C? & This study \\
\hline $1,200 \pm 140$ & $?$ & $1,373-798$ & Peat & Lithic pyroclastic-flow deposit & Tephra C (top) directly & SK88 \\
\hline \multicolumn{7}{|c|}{ Tephra C } \\
\hline $1,020 \pm 50$ & B-55666 & $1,055-796$ & Soil & Lahar deposit beneath Tephra C & Lahar & This study \\
\hline $1,130 \pm 50$ & B-28535 & $1,173-938$ & Burned wood & Pyroclastic-flow deposit beneath Tephra C & $\begin{array}{l}\text { Pyroclastic flow overlying South Point } \\
\text { debris-avalanche deposit }\end{array}$ & BK92 \\
\hline $1,195 \pm 120$ & $?$ & $1,340-835$ & Peat & Tephra C & Tephra C & SK88 \\
\hline $1,280 \pm 80$ & $?$ & $1,336-1,005$ & Buried branch & Pyroclastic-flow deposit and diamict beneath Tephra C & Debris-avalanche deposit & This study \\
\hline $1,290 \pm 80$ & B-28539 & $1,345-1,009$ & Buried branch & Pyroclastic-flow deposit and diamict beneath Tephra C & Debris-avalanche deposit & BK92 \\
\hline $1,400 \pm 50$ & B-28534 & $1,402-1,188$ & Burned log & Pyroclastic-flow deposit & Pyroclastic-flow deposit (near base) & BK92 \\
\hline $1,420 \pm 60$ & B-28538 & $1,508-1,185$ & Soil & $18 \mathrm{~cm}$ of pumice (Tephra C?) & Silt and soil overlying tephra (H?) & BK92 \\
\hline \multicolumn{7}{|c|}{ (Tephra H) } \\
\hline $1,190 \pm 80$ & B-57901 & $1,279-962$ & Peaty soil & Ash beneath Tephra I(?) (Date is anomalously “young”) & Northeast Point debris-avalanche deposit & This study \\
\hline $1,470 \pm 160$ & $?$ & $1,733-1,013$ & & Unknown & Unknown & BK92 \\
\hline $1,500 \pm 155$ & $?$ & $1,774-1,072$ & & Unknown & Unknown & BK92 \\
\hline $1,580 \pm 20^{6}$ & QL-4811 & $1,525-1,411$ & Peat & Peat & Tephra I (distal) & This study \\
\hline $1,610 \pm 70^{8}$ & ETH 3826 & $1,692-1,354$ & Soil & Tephra H & Northeast Point debris-avalanche deposit & BK92 \\
\hline \multicolumn{7}{|c|}{ Tephra I } \\
\hline $1,725 \pm 25^{6}$ & QL-4812 & $1,703-1,562$ & Peat & Tephra I (distal) & Peat & This study \\
\hline $1,830 \pm 80$ & B-24775 & $1,930-1,560$ & Soil & Silt beneath Tephra I & Silt over debris-avalanche deposit & BK92 \\
\hline \multicolumn{7}{|c|}{ Tephra G4 } \\
\hline $2,160 \pm 60$ & B-55674 & $2,324-2,002$ & Peat & Unidentified tephra (Tephra G?) & Pumiceous pyroclastic-flow deposit & This study \\
\hline $2,275 \pm 25$ & QL-4810 & $2,348-2,163$ & Peat & (As below, peat sampled just above $\&$ below ash) & Distal Augustine tephra (near Homer) & This study \\
\hline \multicolumn{7}{|c|}{ Distal tephra ${ }^{5}$} \\
\hline $2,275 \pm 25$ & QL-4810 & $2,348-2,163$ & & Distal Augustine tephra (near Homer) & $\begin{array}{l}\text { (As above, peat sampled just above and } \\
\text { below ash) }\end{array}$ & This study \\
\hline $3,360 \pm 25^{6}$ & QL-4813 & $3,688-3,486$ & Peat & Peat & Distal Augustine tephra & This study \\
\hline \multicolumn{7}{|c|}{ Distal tephra ${ }^{6}$} \\
\hline $3,620 \pm 25^{6}$ & QL-4814 & $4,061-3,849$ & Peat & Distal Augustine tephra (Shuyak Is.) & Peat & This study \\
\hline $3,660 \pm 100^{7}$ & $\mathrm{I}-16120$ & $4,289-3,700$ & Peat & & Distal Augustine tephra (Kamishak Cr.) & RWMC98 \\
\hline
\end{tabular}


Table 2. Radiocarbon ages and stratigraphy of tephra layers at Augustine Volcano-Continued.

\begin{tabular}{|c|c|c|c|c|c|c|}
\hline $\begin{array}{c}\text { Ages (tephra) } \\
\left({ }^{14} \mathrm{C} \text { yr B.P.) }\right.\end{array}$ & Lab. No. & $\begin{array}{c}\text { Calibrated } \\
\text { Ages }^{1} \\
\text { (Calendar yr } \\
\text { B.P.) } \\
\end{array}$ & Material & Overlain by & Underlain by & Reference $^{2}$ \\
\hline \multicolumn{7}{|c|}{ Distal tephra ${ }^{7}$} \\
\hline $3,850 \pm 100^{7}$ & $1-16121$ & $4,225-3,676$ & Peat & Distal Augustine tephra (Kamishak Cr.) & & RWMC98 \\
\hline $5,020 \pm 30^{6}$ & QL-4815 & $5,892-5,659$ & Peat & Peat & Distal Augustine tephra (on Shuyak Island) & This study \\
\hline \multicolumn{7}{|c|}{ Distal tephra ${ }^{6}$} \\
\hline $5,330 \pm 30^{6}$ & QL-4816 & $6,206-5,997$ & Peat & Distal Augustine tephra (Shuyak Is.) & Distal Augustine tephra (Shuyak Is.) & This study \\
\hline \multicolumn{7}{|c|}{ Distal tephra ${ }^{6}$} \\
\hline $6,460 \pm 30^{6}$ & QL-4817 & $7,430-7,316$ & Peat & Distal Augustine tephra (Shuyak Is.) & Peat & This study \\
\hline $6,210 \pm 70$ & B-55676 & $7,270-6,938$ & Marine shells & Allochthonous bay-mud clast & Allochthonous bay-mud clast & This study \\
\hline $7,170 \pm 60$ & B-55675 & $8,161-7,868$ & Marine shells & Allochthonous bay-mud clast & Allochthonous bay-mud clast & This study \\
\hline$\geq 39,890^{8}$ & ETH 7166 & & Charcoal & Waterlaid pumice beneath glacial outwash & Waterlaid pumice & BK92 \\
\hline$\geq 40,440^{8}$ & ETH 7167 & & Charcoal & Waterlaid pumice beneath glacial outwash & Waterlaid pumice & BK92 \\
\hline
\end{tabular}

${ }^{1}$ Raw radiocarbon ages and calibrated (calendar) ages are both in years before A.D. 1950 (= yr B.P.). Samples analyzed by University of Washington Quaternary Isotope Lab (QL) were counted by the direct method and have very low lab-counting standard deviations. Samples analyzed by commercial labs such as Beta Analytic (B) and Isotopes (I) were counted by liquid-scintillation method. Calibrated ages by Oxford University "OxCal." Ranges in calendar years B.P. (before 1950). Calculated to $2 \sigma(95.4 \%)$ confidence level. For some very young samples, negative values B.P. imply time younger that the A.D. 1950 datum; -4 thus =A.D. 1954. Radiocarbon ages older than 20,265 yr B.P are beyond range for calibration. (Bronk Ramsey, 1998, 2000, 2001). Ages earlier calibrated by University of Washington radiocarbon-age calibration program "CALIB REV ver. 4.2" (2000) to generally similar results.

${ }^{2}$ A99, Anders (1999); BK92, Begét and Kienle (1992); SGK89, Siebert and others (1989); SK88, Swanson and Kienle (1988); RWMC98, Riehle and others (1998).

${ }^{3}$ These dates from Red River delta 85 km NE of Augustine in sandy gravel seemingly of 1883 Augustine tsunami (Anders, 1999; Anders and Begét, 1999).

${ }^{4}$ Stratigraphic relation of tephra $\mathrm{G}$ to the date listed just below it is uncertain.

${ }^{5}$ One peat sample, taken immediately above and below the ash at Homer, to closely date this Augustine medium-sand ash.

${ }^{6}$ These seven radiocarbon dates and the four bracketed tephra samples are from section RBW 93Ko.09 on Shuyak Island 110 km SSE of Augustine (plate 2). Tephra identified microprobe analyses of glass fraction by J.R. Riehle and C.E. Meyer, partly discussed by Riehle and others (1998, fig. 8, site 6).

${ }^{7}$ These two radiocarbon dates bracketing a tephra sample are from J.R. Riehle's section along Kamishak Creek on mainland about 70 km SW of Augustine. Tephra identified microprobe analyses of glass fraction by J.R. Riehle and C.E. Meyer, partly discussed by Riehle and others (1998, fig. 8, site 4).

${ }^{8}$ Accelerator Mass Spectrometry (AMS) date. 
Table 3. Stratigraphy of coarse pumiceous "marker-bed" tephra layers and debris-avalanche deposits at Augustine Volcano.

\begin{tabular}{|c|c|c|}
\hline Debris-Avalanche Deposit & $\begin{array}{l}\text { Tephra } \\
\text { Layer }\end{array}$ & $\begin{array}{l}\text { Approx. Age } \\
\left({ }^{14} \mathrm{C} \text { yr B.P.) }\right.\end{array}$ \\
\hline \multicolumn{3}{|l|}{ Burr Point (A.D. 1883) } \\
\hline \multicolumn{3}{|l|}{ Rocky Point } \\
\hline \multicolumn{3}{|l|}{ West Island (incl. Grouse Pt.) } \\
\hline & B & 390 \\
\hline \multicolumn{3}{|l|}{ Southeast Beach } \\
\hline & M & 750 \\
\hline \multicolumn{3}{|l|}{ Lagoon } \\
\hline & $\mathrm{C}$ & $1,000-1,200$ \\
\hline \multicolumn{3}{|l|}{ Long Beach } \\
\hline \multicolumn{3}{|l|}{ South Point } \\
\hline \multicolumn{3}{|l|}{ North Bench (perhaps older?) } \\
\hline & $\mathrm{H}$ & $1,400-1,500$ \\
\hline \multicolumn{3}{|l|}{ Northeast Point } \\
\hline & I & 1,700 \\
\hline \multicolumn{3}{|l|}{ Southeast Point } \\
\hline \multicolumn{3}{|l|}{ Yellow Cliffs } \\
\hline & G & 2,100 \\
\hline $\begin{array}{l}\text { East Point (perhaps comprises } \\
3 \text { separate avalanches }\end{array}$ & & \\
\hline
\end{tabular}

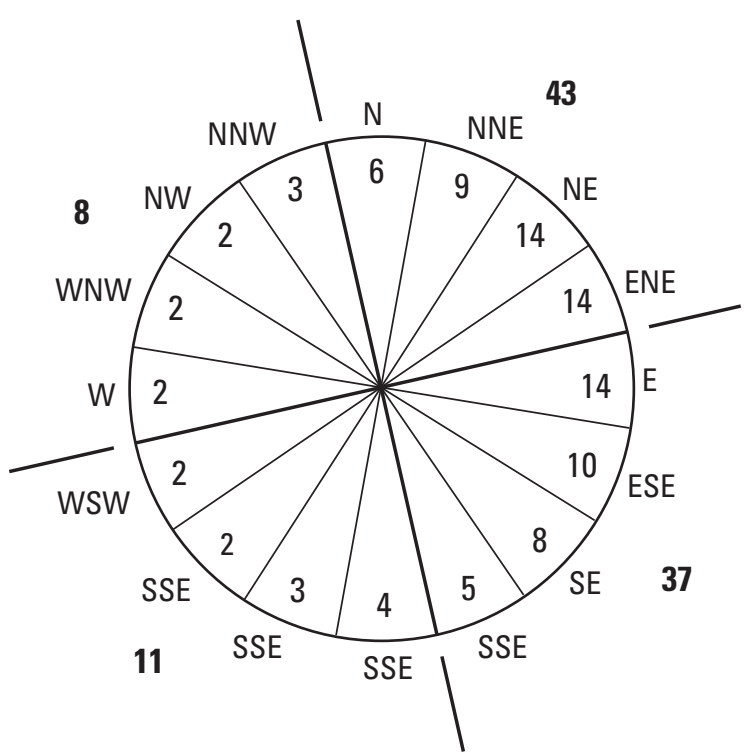

Figure 5. Summary of mean annual wind directions 1949-62 (in percent of mean-annual) from 200 millibar level (about $13 \mathrm{~km}$ altitude) from recording station at Kodiak $180 \mathrm{~km}$ south-southeast of Augustine Island, Alaska (fig. 1). Wind directions for King Salmon $195 \mathrm{~km}$ west-southwest from Augustine and for Anchorage $240 \mathrm{~km}$ northeast are similar. Data from National Weather Service (NOAA) compiled by J. Madore and Tina Neal, USGS.
Limitations to correlating with tephra-index beds are several. Proper identification of the lowest tephra in a sequence is critical to deciphering the age of an underlying deposit. Parts of the tephra sequence are readily distinguishable in the field. Tephra $\mathrm{C}$ in places comprises three coarse horizons and commonly is a couplet of coarser beds separated by finer material. Several decimeters of thin beds of fine sand to silt (ash) separate tephra layers I and H (fig. 6). On the south and west, tephra $\mathrm{M}$ seems everywhere much thicker than tephra B. In sections along the south and east coasts that contain several superposed tephra layers, field characters are usually enough to identify many tephra layers with certainty. But where only one or two tephra layers appear in section, identity can be ambiguous. A tephra may be "missing" at exposed or unstable sites like the crests of levees and hummocks, in areas above the level of vegetation, and on slopes steeper than $15^{\circ}$. Stratigraphic discontinuities caused by erosion soon after emplacement, for instance, are overcome only by exploring numerous sites on any one deposit, including in swales and vegetated areas where a deposited tephra is likely to remain uneroded.

The thickness and particle size of a tephra deposit generally decrease exponentially away from the vent (fig. 8). Numerous Augustine eruptions in the last few millennia have deposited thick and (or) coarse layers of pumiceous tephra on the volcano flanks (tables 2, 3; fig. 6), most recently about 390 years ago. The largest fragments in the coarse tephra layers on Augustine's flanks are many centimeters in diameter. The thickest such deposits are toward the northeast, east, southeast, and south (fig. 7). But between the coarse pumice beds are many finer tephra layers of only sand-size material recording numerous lesser eruptions, including the six historical ones 1812-1986 (figs. 6, 9).

Figure 8 shows the downwind decrease in thicknesses of two coarse Augustine tephras and of several tephras from eruptions from three volcanoes in the Washington and Oregon Cascade Range that typically erupt tephra. The seven curves depict downwind thicknesses for fall for eruptions whose erupted volumes range between about $35 \mathrm{~km}^{3}$ and $0.01 \mathrm{~km}^{3}$. The two major Augustine proximal tephras that are also identified in distal locations are tephra B (about $390 \mathrm{yr}$ B.P.) and tephra I (about 1,700 yr B.P.). Tephra I is about $3 \mathrm{~cm}$ thick at a distance of $110 \mathrm{~km}$, and $\mathrm{B}$ is about $7 \mathrm{~mm}$ thick at a distance of $200 \mathrm{~km}$ (fig. 8). Ash from even a large Augustine eruption would be thinner than $5 \mathrm{~cm}$ on habited areas of Cook Inlet. ${ }^{3}$

During the 1976 pumiceous tephra fall, angular rock fragments as large as $10 \mathrm{~cm}$ punctured a corrugated-steel roof of a hut on Augustine's north-northeast coast $6 \mathrm{~km}$ from the vent (Kienle and Swanson, 1983b, p. 30; Kamata and others, 1991, fig. 4). The moderate eruptions of ash in 1976

\footnotetext{
${ }^{3}$ Davidson (1884) reports second-hand that 4 to 5 inches $(10-13 \mathrm{~cm})$ of ash fell at Kodiak (distance to Augustine $175 \mathrm{~km}$ ) during the 1883 eruption. But stratigraphic sections on Shuyak Island (similar SSE azimuth, at distance 110 $\mathrm{km}$ ) show no large fall just beneath the 1912 Katmai ash (plate 2, sections RBW 93Ko.06 and .09). Casual observers during the 1980 eruptions of Mount St. Helens overestimated ashfall thickness (precompacted) by 2 to 5 times.
} 


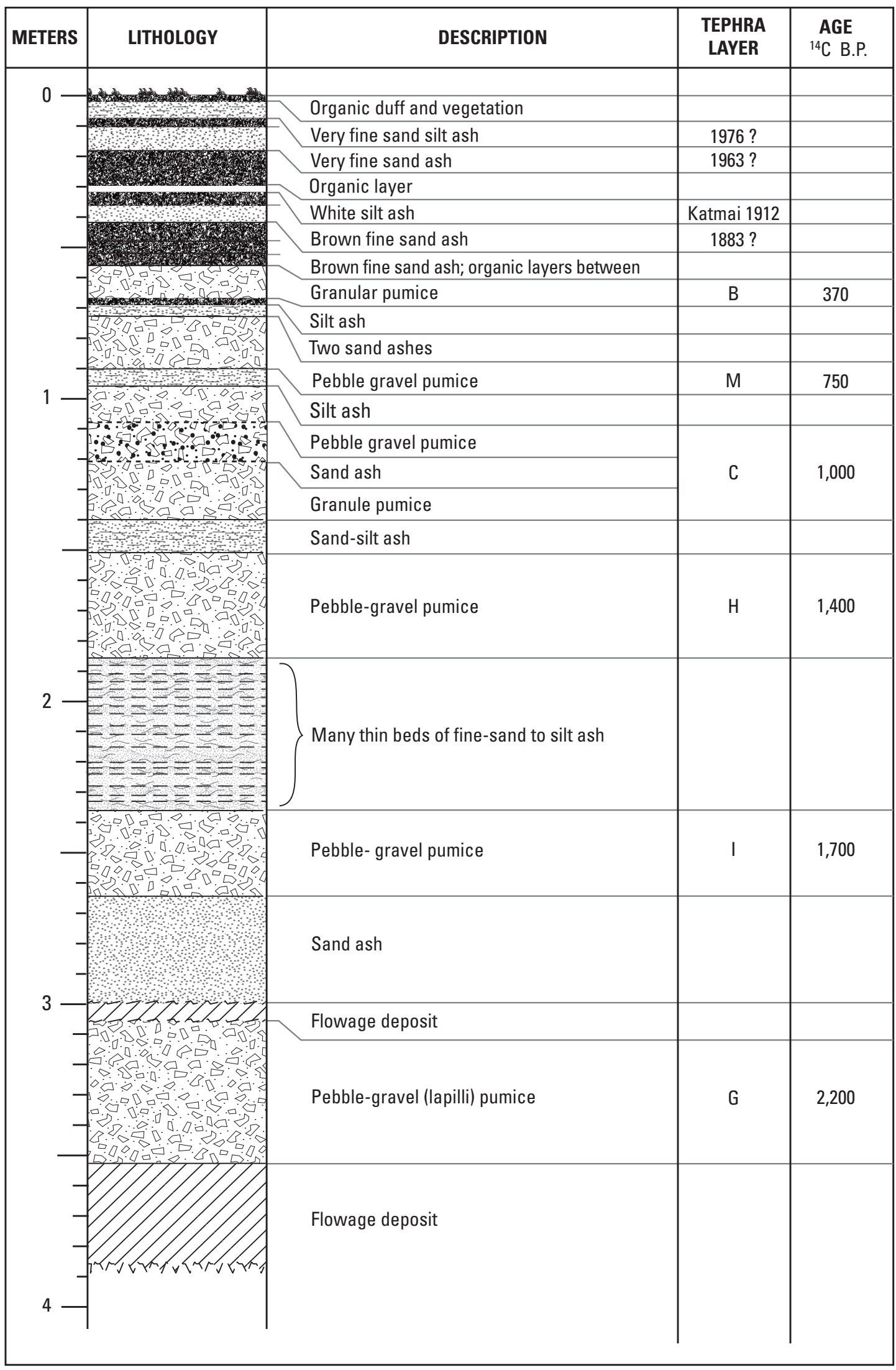

Figure 6. Tephra stratigraphy overlying flowage deposits on Augustine Island just north of Southeast Gully about $0.9 \mathrm{~km}$ coastwise north-northeast from Southeast Point. The flowage deposits are each several meters thick. On plate 2, section RBW 91A.74 (CAG 910804-1) is similar. 

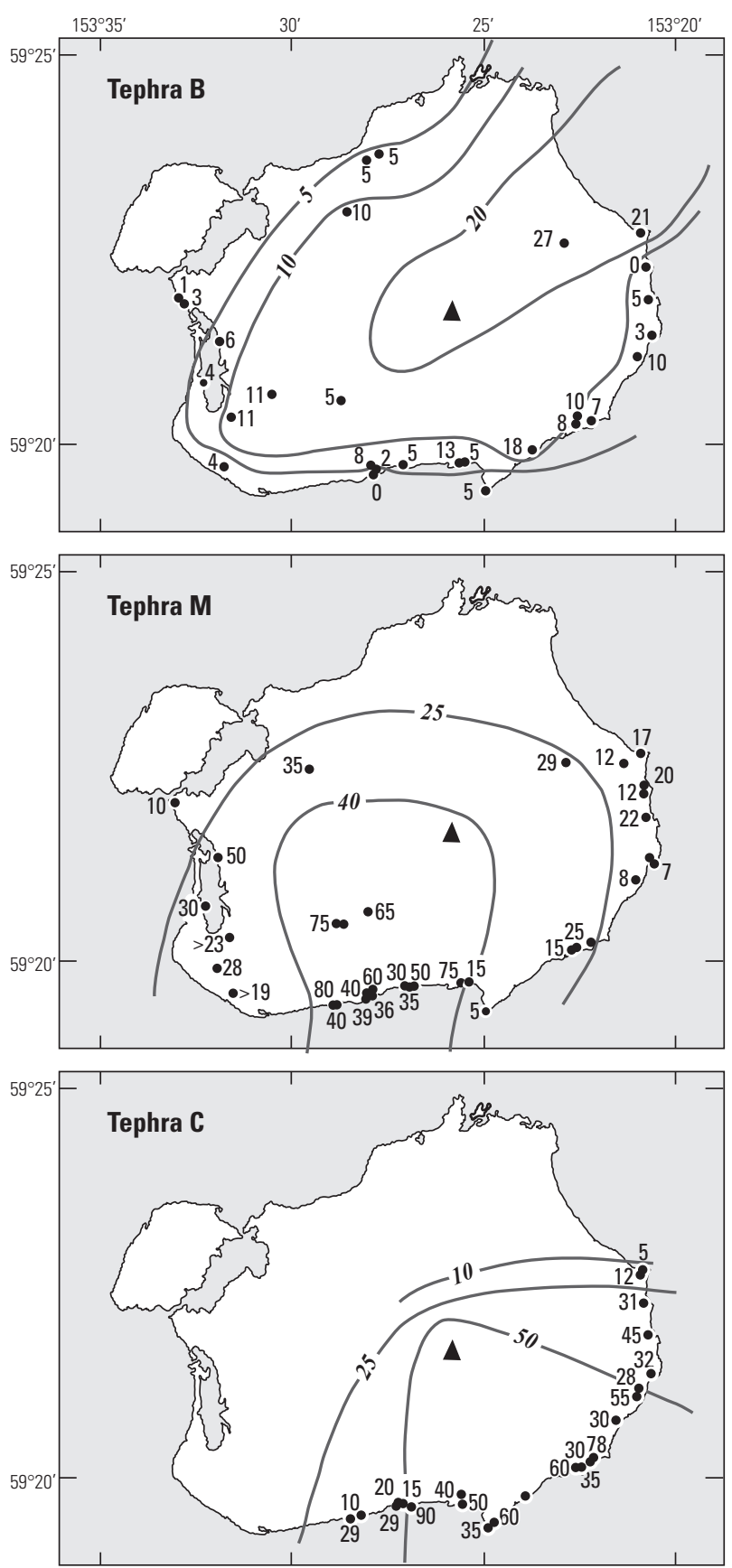

and 1986 were hazardous to air traffic and airports (Kienle and Shaw, 1979).

Tephra layers are much too thin and discontinuous to distinguish as separate map units. A tephra at the surface is thus mapped with the underlying flowage deposit.

\section{Geomorphology}

Many map units are distinguished from neighboring deposits partly by geomorphic relations. Sharp levees define the margins of some debris-avalanche deposits. A deposit fanning gently seaward must be much younger than a neighbor of
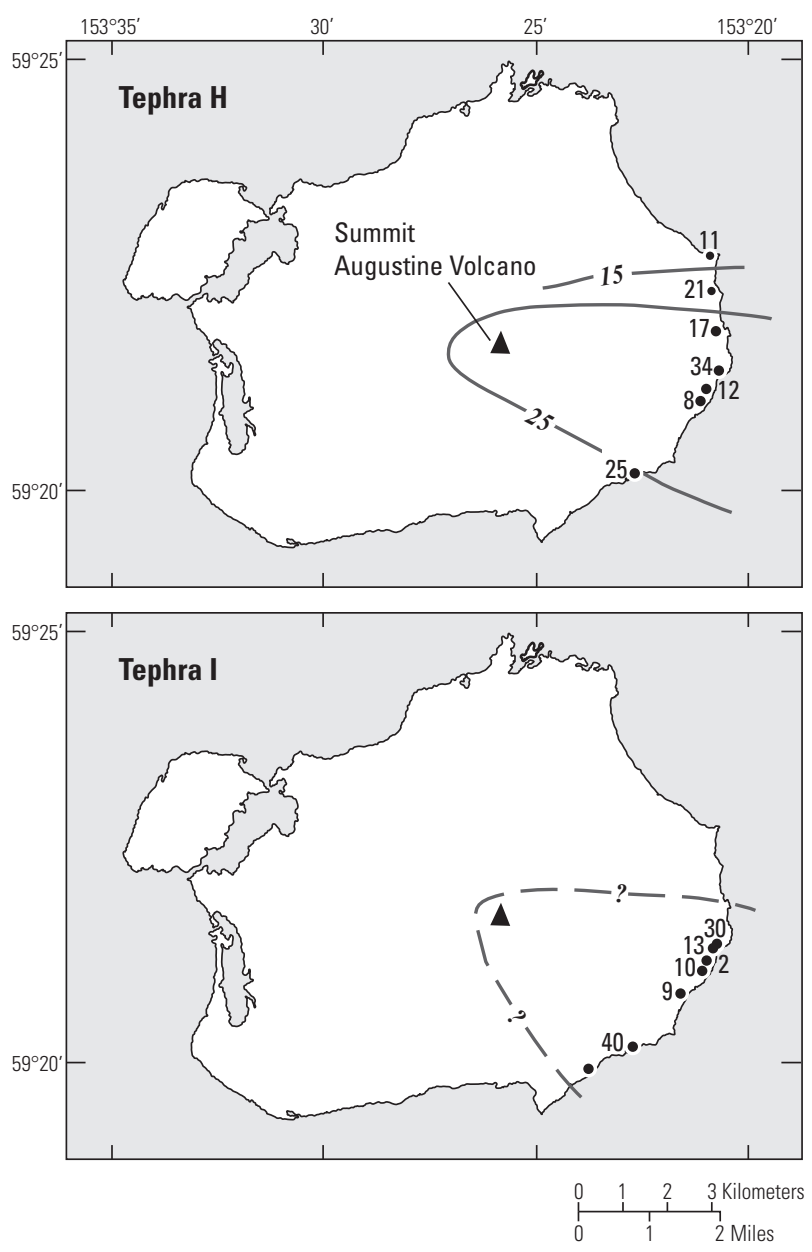

Figure 7. Isopach maps of coarse pumiceous tephra-layers $\mathrm{B}, \mathrm{M}, \mathrm{C}, \mathrm{H}$, and I on Augustine Island, Alaska; values in centimeters. The older tephras, especially $\mathrm{H}$ and I, are confined to the east and southeast where the older deposits lie. Any former exposures to other azimuths have been buried beneath ubiquitous younger deposits.

like material cut back to a straight and high sea cliff. A unit far more vegetated than its lithologically similar neighbor at the same altitude must be much older.

Sea waves over time erode back any unconsolidated debris shed to the coast. Augustine's coastal cliffs rise as high as $40 \mathrm{~m}$, cut far back into ancient deposits. A sea cliff (fig. 10A) ceases to develop when a flowage from a new eruption overrides and spreads beyond the cliff, shifting the coast seaward (fig. 10A,B). Or a sea cliff can be surrounded by a flowage down an adjacent gully that then spreads along the coast, isolating the cliff from the sea (fig. 10C). Many such sea cliffs lying back from Augustine's present coasts tell of 
gradual wave erosion suddently arrested when new eruption deposits arrive (plate 1).

Details of topography help to identify emplacement mechanisms. Debris-avalanche deposits are distinguished from other types of flowage deposits by their composition of coarse angular diamict freighted with huge angular dome-andesite boulders and by their topography of high conical hummocks and intervening closed depressions. Hummocky topography also shows in bathymetric contours offshore of most of Augustine's debris-avalanche deposits (fig. 11), pointed out by previous authors (Kienle and Swanson, 1983b; Begét and Kienle, 1992; Siebert and others, 1995). Below wave base and isolated from pyroclastic and other flows that have smoothed onshore topography, the characteristic hummocky form of the offshore deposits is preserved. This bathymetry is evidence that several of these debris avalanches extend as far as $1-4 \mathrm{~km}$ and to depths of 25-45 $\mathrm{m}$ beyond present coasts. Where two or more debris-avalanche deposits lie atop one another, as along the east and southeast coastal cliffs, the offshore deposit may correlate with one or both or several avalanches.

Lithic pyroclastic-flow deposits comprise gravelly sand or sandy gravel of angular clasts. One or several pairs of levees lead down to intricately multilobate termini. These flowage deposits are not characteristically hummocky, yet between levees and adjacent channels there can be several meters of local relief. This geomorphic character helps distinguish them from the hummocky debris-avalanche deposits.

\section{Distinguishing Lithic Pyroclastic Flows from Lahars in Proximal Areas}

Bouldery lithic pyroclastic flows (hot dry flows) and debris-flow lahars (cool wet flows) may leave similar deposits that are lithologically and geomorphically difficult to distinguish from each other. In a hot pyroclastic flow, any contained wood is baked or turned to charcoal, but in a cooler debris flow wood remains fresh though perhaps abraded. Yet on weakly vegetated and shallow-gullied Augustine Volcano, deposits are all but devoid of wood fragments.

Actively extruding dacite domes on Mount St. Helens, as observed by R.B. Waitt in April 1982, repeatedly slough hot-rock avalanches. While cascading and flowing to lower slopes this thermally stressed rock continuously and profusely breaks into very angular gravel fragments that exude roiling clouds of sand-sized fragments. A lithic pyroclastic flow from such a dome failure is monolithologic, the clasts very angular, commonly unabraded; on cooling a few may be radially prismatically jointed, indicating a hot-rock source. The matrix of a pyroclastic-flow deposit tends to be loose.

More adept at eroding its bed, a moving debris flow or lahar incorporates a mixture of clast types, some of them becoming abraded. The water in a debris flow concentrates finer particles, which adhere to each other, drying to a tough matrix. A debris flow that has traveled many kilometers may be thus distinguished from a far-traveled lithic pyroclastic flow. But on Augustine's fairly steep slopes and only 2 to $4 \mathrm{~km}$

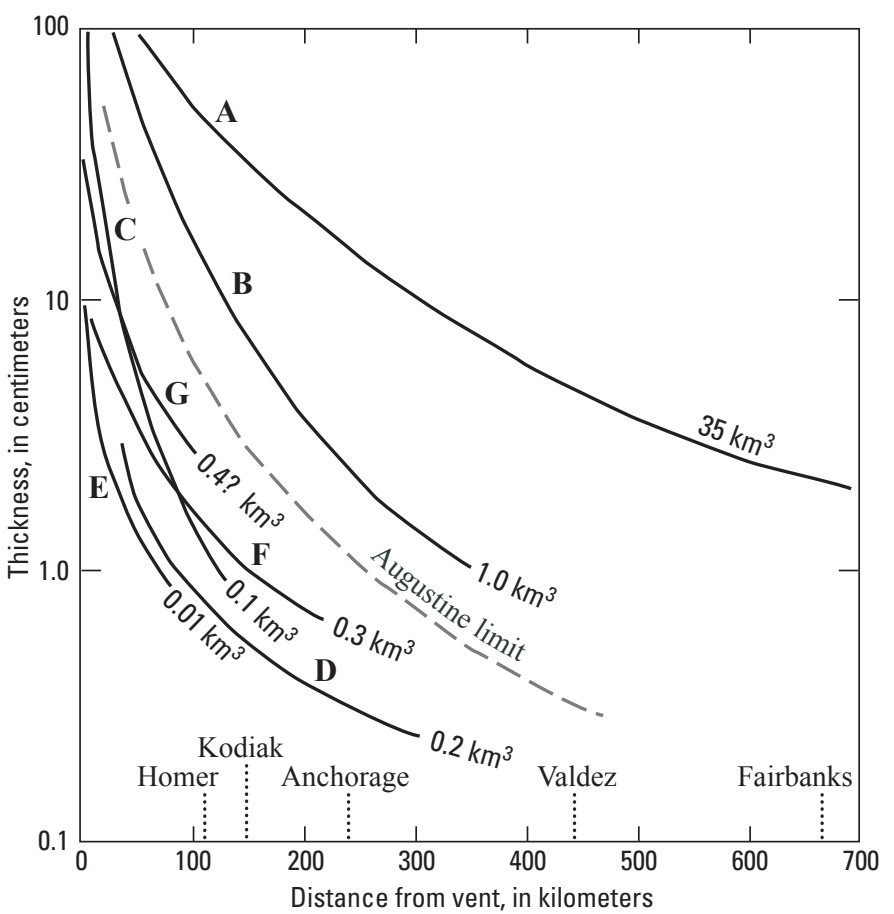

Figure 8. Thickness of some sheets of tephra erupted from volcanoes in western United States plotted against distance downwind. A, Mount Mazama (Crater Lake) $\left(35 \mathrm{~km}^{3}\right)$; B, Mount St. Helens layer $Y n\left(1 \mathrm{~km}^{3}\right)$ C, Mount St. Helens layer T $\left(0.1 \mathrm{~km}^{3}\right)$; D, Mount St. Helens 18 May $1980\left(0.2 \mathrm{~km}^{3}\right)$; E, Glacier Peak layer $D\left(0.01 \mathrm{~km}^{3}\right) ; F$, Augustine layer $B\left(0.3 \mathrm{~km}^{3}\right) ; \mathrm{G}$, Augustine tephra I $\left(0.4\right.$ ? $\left.\mathrm{km}^{3}\right)$. Data from Williams and Goles, 1968; Crandell and Mullineaux, 1978; Sarna-Wojcicki and others, 1981; Begét and others, 1994 (for Augustine tephra B); and R.B. Waitt (for Augustine tephra I). Dashed line depicts inferred maximum tephra accumulation downwind from Augustine Volcano. Alaskan cities at bottom are plotted at distance from Augustine's summit vent.

from summit source, such textural distinctions can be subtle. Because Augustine lacks glaciers and by late summer harbors only a few snowfields, its eruptions generate lahars by swift melting only in winter-spring. Even the winter eruptions of 1976 and 1986 caused only small lahars down gullies, while pyroclastic flows (pumiceous and lithic) were far broader and more voluminous. Pierson and others (in press) discuss in some detail these and other criteria by which such look-alike flowage deposits of unlike origins may be distinguished.

\section{On Map “Units"}

The various Augustine deposits, lava domes, and old rocks described in this report are physical realities. The large ones, as exposed at the surface, are depicted on the geologic map (plate 1) as "units." Unlike the materials themselves, map "units" stem considerably from a cartographer's imagination. 


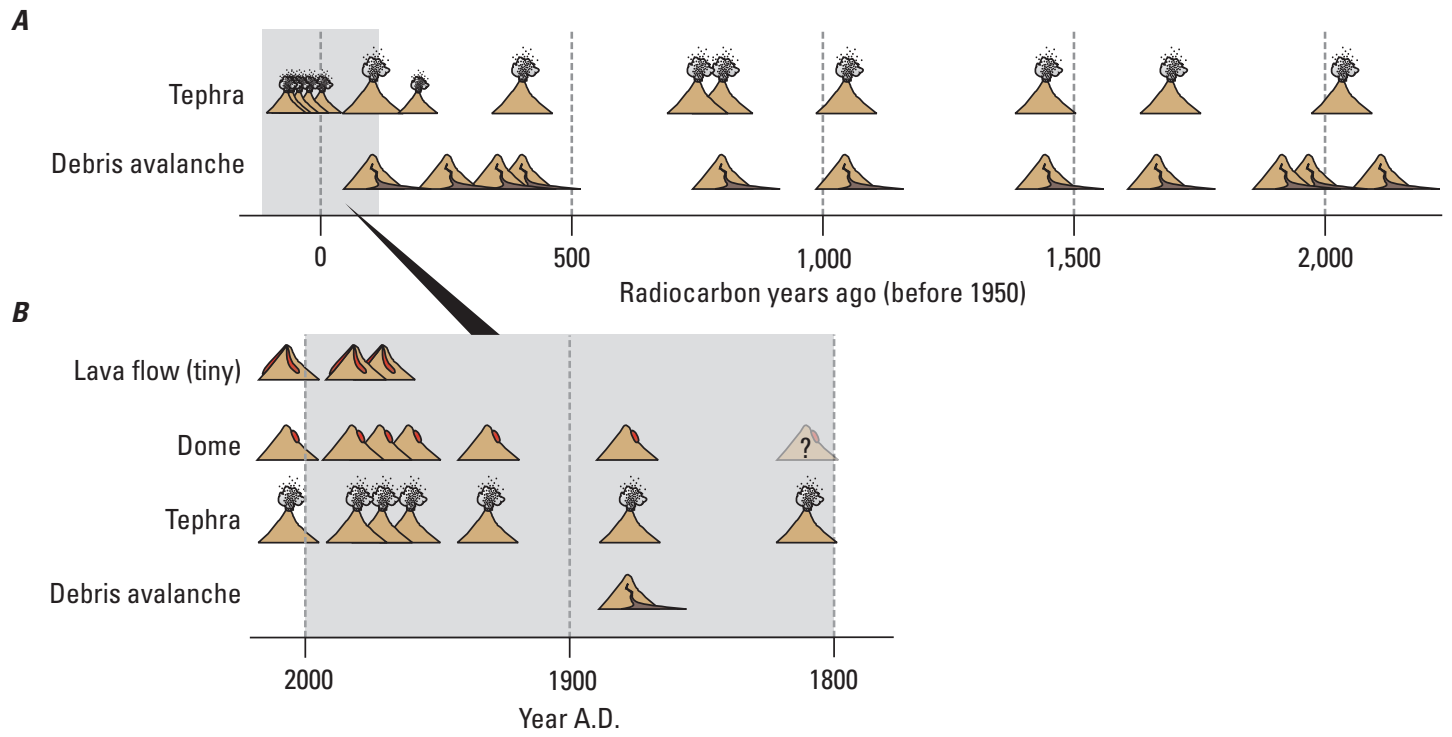

Figure 9. Summary of eruptive history of Augustine Volcano based on data in this report. $A$, past $\sim 2,200$ radiocarbon years; as calculated on conventional radiocarbon timescale, "ago" means before 1950. Thus the symbols representing eruptions between 1963 and 2006 plot in the future (on radiocarbon timescale). $B$, historical eruptions (last two centuries). $A$ depicts mostly large eruptions, $B$ mostly smaller ones.

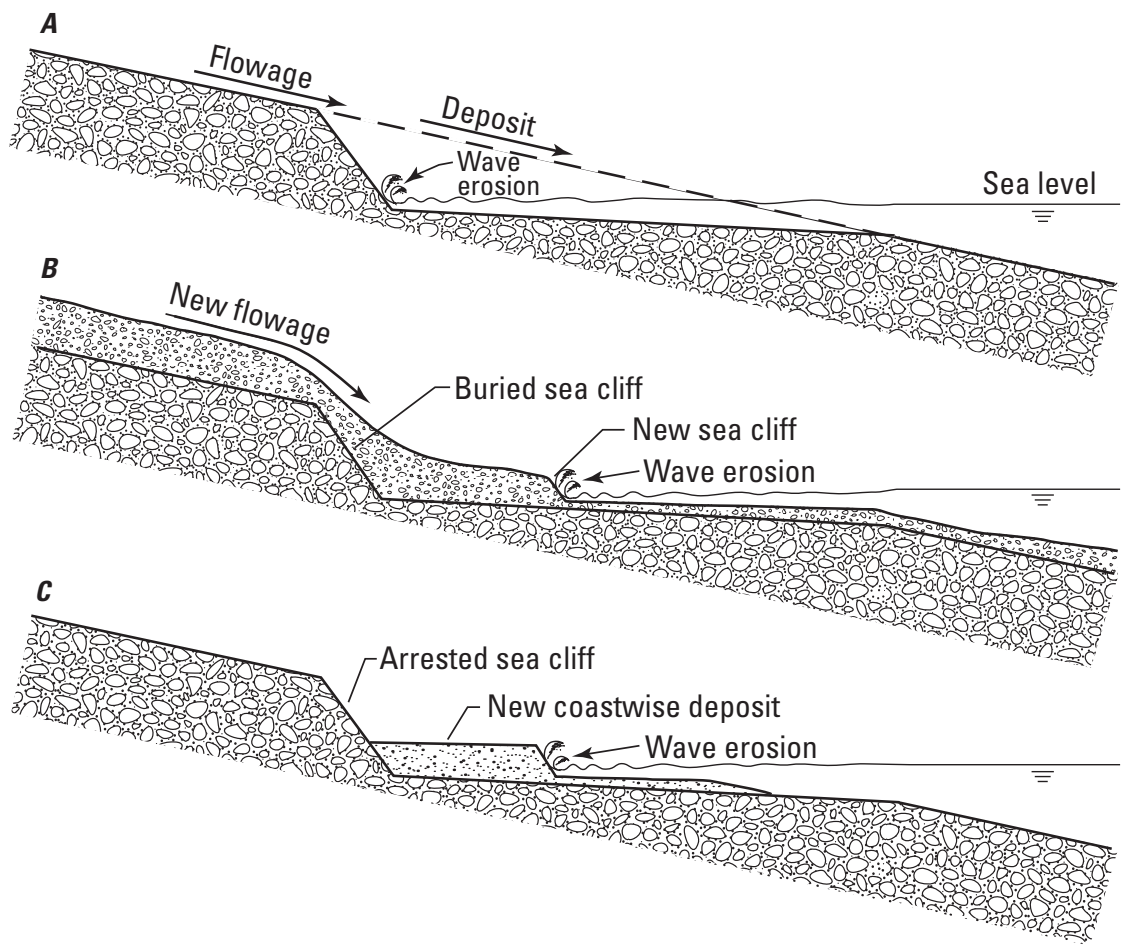

Figure 10. Sketch showing in profile development of arrested sea cliffs at Augustine Island. $A$, High sea cliff cut into flowage (such as debris-avalanche) deposit. Wave erosion of this cliff can be arrested by either B or C. B, Initial sea cliff is overridden by new flowage deposit, which isolates initial cliff by moving coast seaward; into this deposit a new sea cliff is cut. $C$, Initial sea cliff is isolated from sea by a coastwise flow delivered through an adjacent side gully; into this deposit a new sea cliff is cut. 
A heading may be "Lagoon debris-avalanche deposit (unit CMal)." The deposit is natural reality, but the "unit" is invented to portray on a map and to organize discussion. A deposit may extend beneath younger deposits well beyond its expression as a map unit, or it may be subdivided into smaller "units." For instance, profuse, large boulders just offshore of Augustine Island are clearly relics of the onshore debris avalanches. But there may be no objective way to link them to a particular avalanche, nor by cartographic convention does a map unit show if it's below water. So these offshore elements are designated as a separate map unit (unit ob) though they are but a continuation of an onshore deposit. Future investigators may define and portray units differently, as our map differs from earlier maps. But it is the same materials that constitute Augustine Island.

\section{Synopsis of Geologic History}

Augustine Volcano began erupting before the late Wisconsin glaciation (late Pleistocene) on the flank of a small island of upper Jurassic to upper Cretaceous sedimentary rock in lower Cook Inlet, Alaska. The oldest known effusions ranged from explosive eruptions of olivine basalt interacting with water to dacitic or rhyodacitic pumiceous pyroclastic flows. Late Wisconsin piedmont glaciers issuing from the mountainous western mainland surrounded the island at a time when dacitic eruptive debris swept down the south volcano flank.

Augustine erupted between the late Wisconsin and about 2,200 ${ }^{14} \mathrm{C}$ yr B.P., ${ }^{4}$ but the evidence on Augustine Island is scant. On a few south-flank inliers, pumiceous pyroclasticflow and several pumiceous-fall deposits below a peat dated to about 2,160 yr B.P. (table 2) reveal at least several early to middle Holocene silicic eruptions of Augustine. Between about 6,460 and 2,275 yr B.P., several Augustine silicic tephras reached sites $25 \mathrm{~km}$ northwest, $70 \mathrm{~km}$ southwest, $110 \mathrm{~km}$ southeast, and (or) $110 \mathrm{~km}$ northeast of Augustine Island (table 2) (see below).

From somewhat before 2,200 yr B.P. to the present, numerous debris avalanches have swept to Augustine's coast and beyond, most recently in A.D. 1883 (fig. 9). The decapitated summit after the 1883 landslide and replacement by andesite domes of six eruptions since then suggest common processes: collapse of the steep summit dome flowing as an avalanche to the sea, then regrowth of the summit by later dome eruptions - this pattern repeated again and again.

The volcano shed several large debris avalanches before 1,400 yr B.P. Beneath tephra G (probably older than $2,100 \mathrm{yr}$ B.P.) along the east coast lies a coarse, hummocky debris-avalanche deposit — or a stack of 2 or 3 of them - the oldest exposed such deposit(s) on Augustine Island. Between

\footnotetext{
${ }^{4}$ Such dates throughout report and on explanation to the map are in raw (uncalibrated) radiocarbon time. See discussion under heading "Radiocarbon Ages" and in table 2 .
}

about 2,100 and 1,800 yr B.P. (between tephras $\mathrm{G}$ and I) two large debris avalanches swept east and southeast into the sea. Between 1,700 and 1,400 yr B.P. (between tephras I and H) a large debris avalanche shed east and east-northeast into the sea.

Since 1,400 yr B.P. Augustine Volcano has repeatedly shed debris avalanches and other flows. Between about 1,400 and 1,100 yr B.P. (between tephras $\mathrm{H}$ and $\mathrm{C}$ ) one debris avalanche swept into the sea on the south, another on the southwest, and a third on the north-northwest. Pumiceous pyroclastic fans spread to the southeast and southwest, lithic pyroclastic flows and perhaps lahars to the south and southeast. Between about 1,000 and $750 \mathrm{yr}$ B.P. (between tephras $\mathrm{C}$ and $\mathrm{M}$ ) a debris avalanche swept to the sea on the west, and pyroclastic flows, pyroclastic surges, and lahars swept down the west and south flanks. Between about 750 and 400 yr B.P. (between tephras $\mathrm{M}$ and B) a small debris avalanche swept into the sea on the south-southeast. Lithic pyroclastic flows shed to the southeast; smaller ones descended existing swales on the southwest and south. Between about $400 \mathrm{yr}$ B.P. (after tephra B) and the 1770s, three debris avalanches swept into the sea on the west-northwest, north-northwest, and north flanks. One of them (West Island) was large and fast, most of it having ridden to sea far beyond a sea cliff cut back into older deposits. Augustine's only conspicuous lava flow erupted on the north flank.

During this prehistoric period numerous domes must have grown at the summit, renewing material repeatedly shed off as catastrophic debris avalanches. Remnants of these older domes form the east and south sides of the present summit-dome complex. Below the summit area at least three domes grew on the upper flanks, one on the south (Kamishak), and soon after $390 \mathrm{yr}$ B.P. two on the northwest. Another undated and nearly buried dome or lava flow lies on the middle south flank. Intermittently throughout the late Holocene period many smaller eruptions emplaced beds of sand-sized ash on the volcano flanks, in between larger eruptions that deposited the conspicuous coarsely pumiceous fall beds. During at least the past 750 years, beach and backbeach eolian dunes accreted at the southwest coast, forming faintly ribbed coastal topography there. Lesser dunes grew at the backs of beaches in several coves on the northwest, north, and northeast flanks.

In historical times an eruption in 1883 shed a debris avalanche into the sea on the north-northeast, followed by pyroclastic flows and surge. Eruptions in 1935 and 1963-64 grew summit domes that spilled respectively over the southwest and south rim and shed coarse rubbly lithic pyroclastic flows down those flanks. Eruptions in 1976 and 1986 grew domes that draped down the north flank and shed voluminous pyroclastic flows to the northeast, north, and northwest flanks. During these last two eruptions but especially in 1976, smaller pyroclastic flows and (or) lahars swept down valleys on other flanks. In early 2006 came a new eruption that emplaced a dome and stubby lava-flow extensions on the upper north-northeast flank. Only one large lithic fragmental flow reached the lower north flank. 


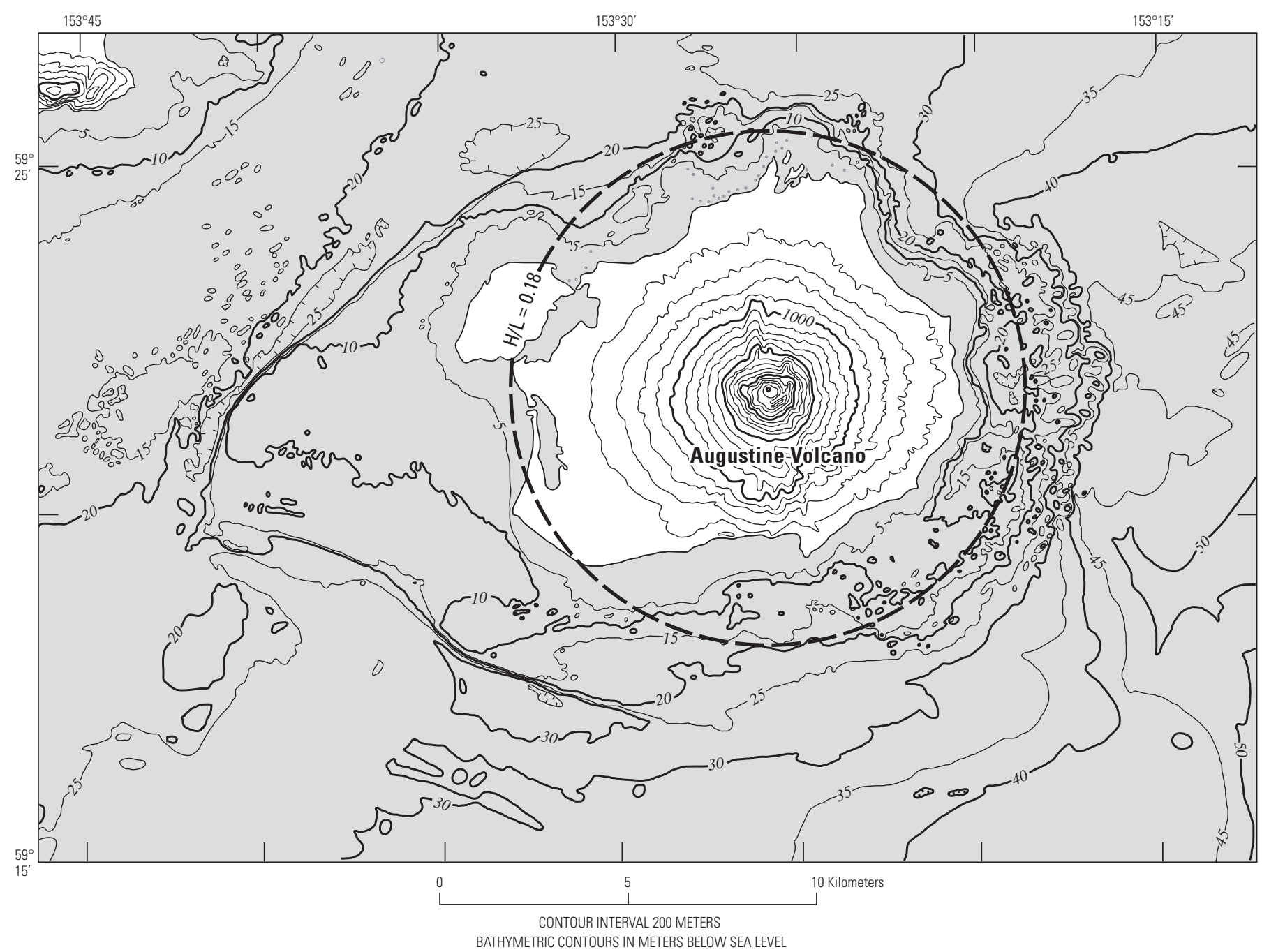

Figure 11. Offshore distribution of debris avalanches off Augustine Island based on seaward extent of conspicuously hummocky submarine topography. The 200-ft contours on Augustine Island and the 5-m contours of bathymetry are traced from U.S. Geological Survey 1:250,000 lliamna quadrangle. The hummocky topography extends to depth of $45 \mathrm{~m}$ and as far as $3.8 \mathrm{~km}$ off east coast; it extends to depth $25 \mathrm{~m}$ as far as $2.8 \mathrm{~km}$ off north coast. Significance of circle-H/L ratio $=0.18$-explained in section on "Mobility and Speed of Volcanic Debris Avalanches."

\section{Pre-Augustine Mesozoic Rocks}

Sedimentary bedrock constituted Augustine Island before the volcano existed (fig. 12). This rock reaches from below sea level at the south coast to as high as altitude $400 \mathrm{~m}$, the lower $300 \mathrm{~m}$ mapped by Buffler (1976). Constituent invertebrate fossils (especially pelecypods) identify most of these rocks with the Upper Jurassic Naknek Formation (Detterman and Jones, 1974). The typically gently dipping Naknek in its type area crops out thickly and broadly on the Alaskan Peninsula along tectonic strike 50-180 km south-southwest of Augustine (Keller and Reiser, 1961, plate 29), and on the nearest points of the Peninsula, 15-20 km southwest, west, northwest, and north of Augustine (Detterman and Reed, 1964; Detterman and Hartsock, 1966; Magoon and others, 1976, mapsheet 2).
On Augustine Island the Naknek Formation comprises a lower member of thin-bedded dark-gray siltstone to very fine sandstone (unit Jnsh, plate 1) (fig. 13A) and an upper member of cliff-forming thick-bedded, medium to fine sandstone in places showing trough-type fluvial crossbeds 10 to $20 \mathrm{~cm}$ tall (unit Jns) (fig. 13B). Though deposited in a marine environment, the sandstone contains flattened fossil logs and pods of lignite. These suggest a nearshore environment of deposition, perhaps a protected bay. The bedrock block dips southeast, south, and south-southeast variably at 5 to $36^{\circ}$, mostly 8 to $20^{\circ}$. The south dips are despite the subsequent overgrowth of the volcanic edifice that must have isostatically depressed the bedrock northward, flattening these dips. The cliff-forming upper sandstone is exposed almost continuously for more than $2 \mathrm{~km}$ along strike below altitude $280 \mathrm{~m}$. 
Below Kamishak dome at the head of West Kamishak Creek (fig. $1 B$ ) lies a patch of highly oxidized and soft-weathered greenish sandstone and sandy pebble conglomerate at altitudes 350 to $400 \mathrm{~m}$, poorly exposed in a gully head and poking up sparsely and discontinuously through overlying coarse andesitic rubble for $350 \mathrm{~m}$ to the southwest. The gully exposure (unit Kk) is one of three outcrops in which Detterman and Jones (1974) identify fossils including Inoceramus pelecypod (clam) of late Campanian to early Maestrichtian (upper Cretaceous) age (Jones and Clark, 1973). They correlate these rocks with the fossiliferous Kaguyak Formation in the uplands of Cape Douglas on the Alaskan Peninsula $65 \mathrm{~km}$ south-southwest of Augustine (Jones and Detterman, 1966) and the coastal type section along Kaguyak Bay $90 \mathrm{~km}$ south-southwest of Augustine (Keller and Reiser, 1961, p. 275-277 and plate 29; Jones, 1963).

The western two outcrops bearing upper Cretaceous fossils examined in 1972 and 1974 (Detterman and Jones, 1974; Buffler, 1976) along Augustine Creek at altitudes 150 to $250 \mathrm{~m}$ seem no longer to exist, evidently buried by thick pyroclasticflow and laharic deposits of the 1976 Augustine eruption now mapped in that area.

The conspicuously smooth slopes broadly between sea level and about $550 \mathrm{~m}$ and between azimuths south-southeast and south-southwest, including an inlier to the west along Augustine Creek are fundamentally of this bedrock but thickly mantled by Augustine pumicous flow and fall deposits. The Mesozoic rock must have existed as an island before Augustine Volcano began to erupt. Slopes of 20 to $30^{\circ}$ projected north from today's outcrops suggest that the buried north part of this island lies beneath the Augustine central vent (see cross section on plate 1).

Along the south coast of Augustine Island, angular boulders of fossiliferous sandstone are common within the Long Beach debris-avalanche deposit (map unit $\mathrm{HCal}$ ) and among the beach boulders eroded from it by waves. These sandstone boulders extend as far as $2 \mathrm{~km}$ west of the westmost gully that today can convey such blocks from existing outcrops to the coast. This distribution indicates that the Jurassic-Cretaceous bedrock lies buried beneath Augustine debris at least $0.4 \mathrm{~km}$ northwest of the present limit of outcrop.

Springs emerge at the contact of the Naknek sandstone with the underlying shale, water that by sapping contributes to retreat and maintenance of the prominent upper cliff. A wet layered sequence sloping toward a steeply incised cliff is conducive to landsliding. Such a landslide seems the cause of a highly fractured block of the sandstone member lying at the south coast (unit PI).

\section{Pleistocene to Late Holocene Materials}

\section{Pleistocene Deposits}

Pleistocene materials crop out sporadically on Augustine's south flank - a landslide block, glacial deposits, and volcanic materials.

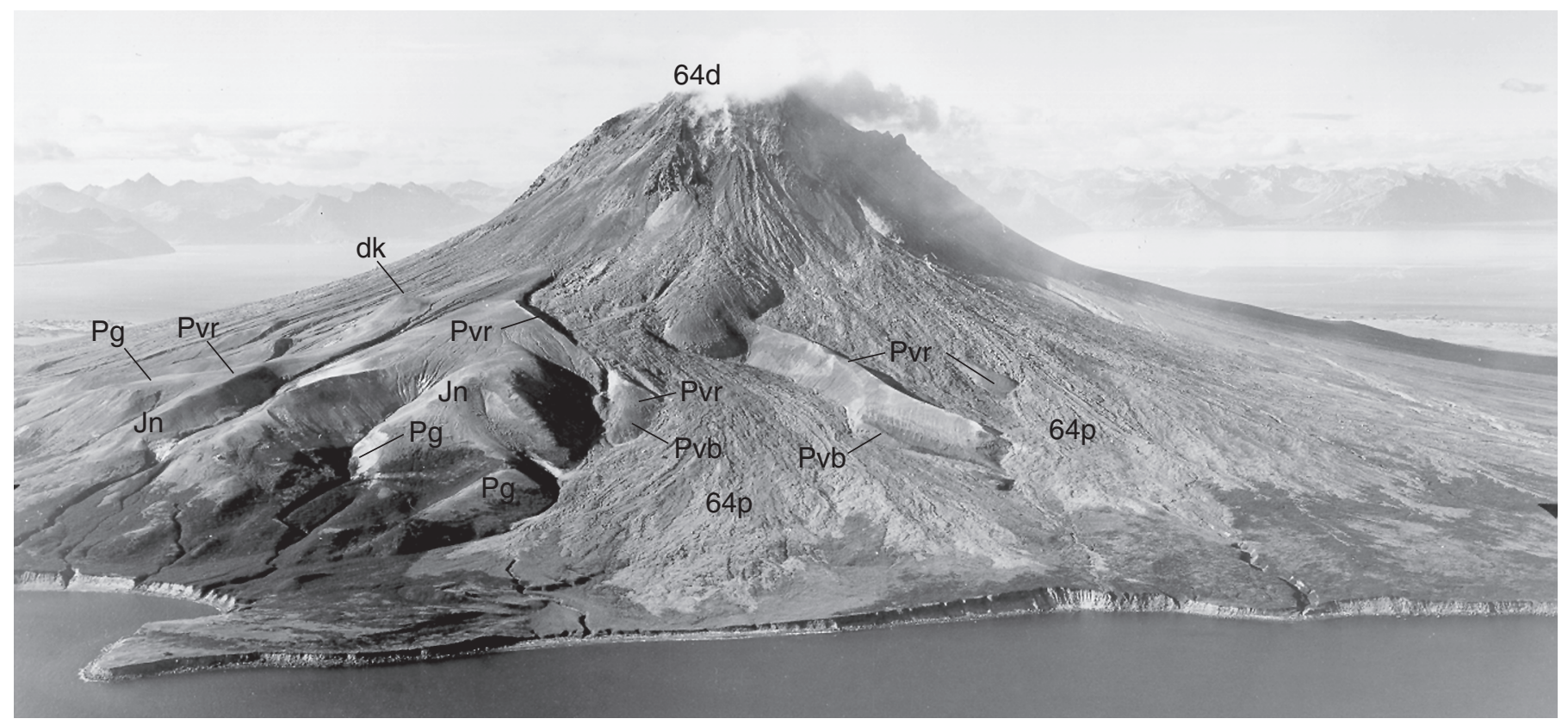

Figure 12. Oblique aerial view north-northwest of Augustine Volcano. Most geomorphically smooth topography of south flank is block of Jurassic Naknek Formation (Jn) that is being gradually buried by the growing Augustine cone and is capped by many meters of Augustine fall deposit. Also shown are locations of Kamishak dome (dk) and Pleistocene deposits: basaltic hyaloclastite (Pvb), rhyolitic fall and flow deposits (Pvr), and glacial deposit (Pg). Photo taken just after end of growth of 1964 dome (64d), from which are extensive coarse deposits of 1963-64 pyroclastic flows (64p). Map-unit symbols (parentheses) from plate 1. (USGS photograph by Austin Post, 3 September 1966.) 

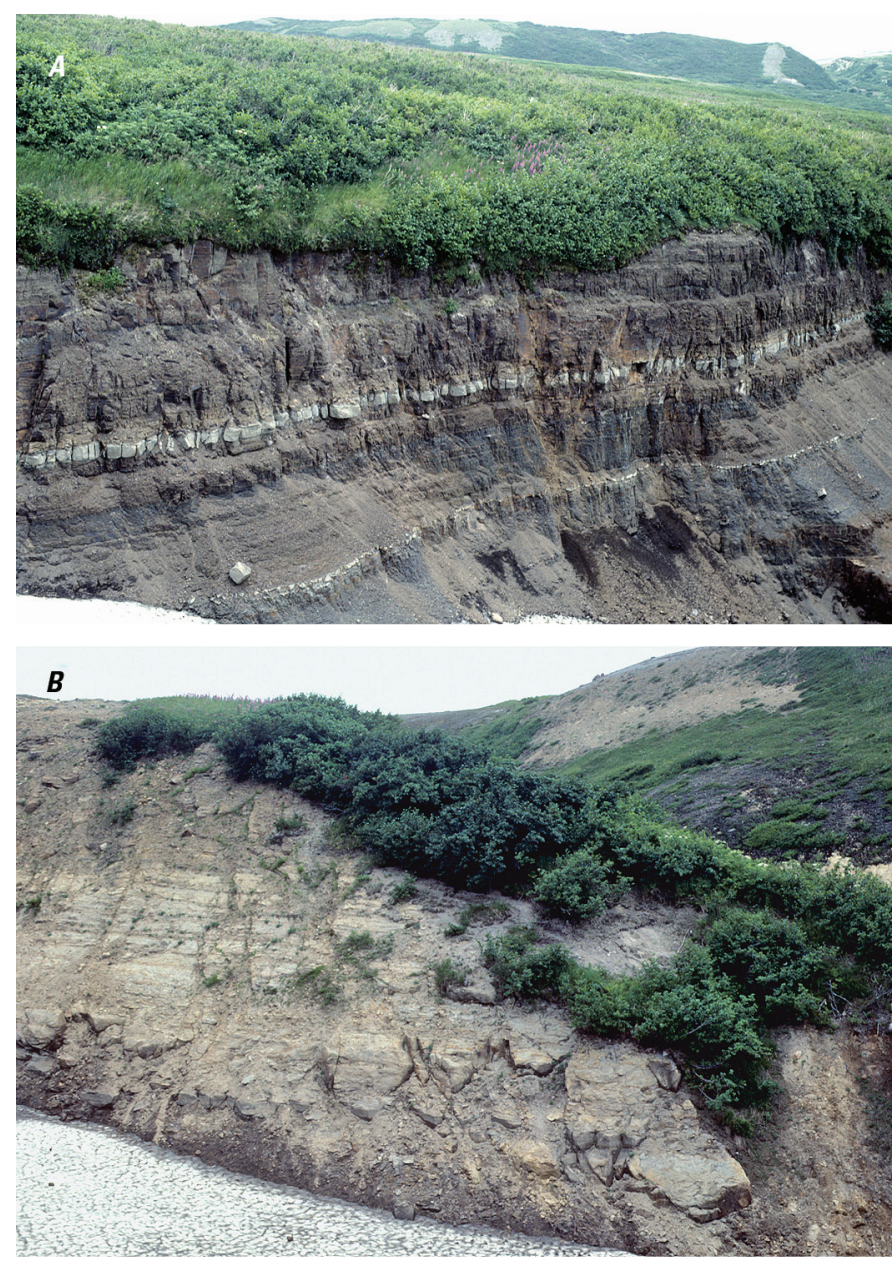

Figure 13. View of Naknek Formation (Jurassic) on south side of Augustine Island. $A$, shale facies (map unit Jnsh). $B$, sandstone facies (map unit Jns). (USGS photographs by Richard Waitt.)

\section{Landslide Block}

A block along the south coast east of the mouth of West Kamishak Creek is $500 \mathrm{~m}$ long and $60 \mathrm{~m}$ high of nearly intact sandstone of the upper member of the Naknek Formation, which crops out $200 \mathrm{~m}$ higher. By its size this rock at first appears in situ (fig. 14), and Detterman (1973) so mapped it. But unlike unambiguously in-situ rock, the coastal block (unit $\mathrm{PI}$, plate 1) is riddled with small faults and joints, some of them open fissures. Bedding is highly variable, dips as steep as $43^{\circ}$, and even some anomalous north dips as steep as $35^{\circ}$. These properties suggest many subblocks that have jostled and rotated with respect to each other. The block is cut back into a 50-m-high sea cliff, and wave-beveled sandstone is exposed at low tide as much as $100 \mathrm{~m}$ seaward of the cliff. Despite its enormous size and the near continuity of rock, the exposure seems clearly to be a block landslide, as Buffler (1976) tentatively suggested. Probably the sandstone block slid gradually, on a wet sole of the underlying shale.

\section{Glacial Deposits}

Scattered surface exotic stones or diamicts containing exotic stones, some of them glacially striated, crop out at several places on the south flank (unit Pg, plate 1). These stones range from angular to rounded and from pebbles to boulders as large as $1.6 \mathrm{~m}$ (fig. 15). Among the diverse rock types are granite, granodiorite, diorite, quartz diorite, gabbro, diabase, porphyritic dike rocks, granite-gneiss, hornfels, greenstone, amphibolite, vein quartz, banded limestone and chert, and argillite. All these rocks are exotic to Augustine Island. They seem derived from the nearby glaciated, mountainous terrain (Detterman and Reed, 1964; Detterman and Hartsock, 1966) along the west side of lower Cook Inlet. The coarse and striated stones appear to be ice-deposited till, not deposits within a glacial lake as Johnston (1979) inferred. Most of the glacial deposits contain locally derived rounded pumice; some of them also contain clasts of nearby Naknek Formation sandstone.

All the exotic stones are unweathered and hard, probably of the last (late Wisconsin) glaciation. Radiocarbon dates show that the late Wisconsin glaciation in Cook Inlet region occurred between about 30,000 and $12,000{ }^{14} \mathrm{C}$ yr B.P. (Karlstrom, 1964; Hamilton and Thorson, 1983, p. 46-47). The scattered debris on Augustine Island that contain exotic stones lie between altitudes 120 and $290 \mathrm{~m}$ but apparently no higher. This altitude may register the height to which coalesced late Wisconsin piedmont glaciers descending from western mountains had filled lower Cook Inlet (during lowered global sealevels) and banked against Augustine Volcano, perhaps about 15,000 years ago (Hamilton and Thorson, 1983, fig. 2.4). On a spur $1 \mathrm{~km}$ north of South Point, Johnston (1979) reported exotic stones as high as $320 \mathrm{~m}$. But the range of unarguably glacial exotic stones in that area is 230 to $275 \mathrm{~m}$, like that on a spur $1.6 \mathrm{~km}$ farther west ( 250 to $290 \mathrm{~m}$ ). The exotics Johnston reported higher are much smaller and far more rounded, apparently weathered from congomerate beds within the Jurassic Naknek Formation.

As Johnston (1979) reported, glacial debris on spots seems to overlie the Mesozoic bedrock, no Augustinian volcanic debris in between. He inferred that Augustine began erupting just after the late Wisconsin. But pumice within some glacial deposits and the some "old" dates (see below) suggest that Augustine had erupted earlier or that some of the glacial deposits are older than late Wisconsin.

A section at 10 to $30 \mathrm{~m}$ altitude overlying the southcoastal landslide block (unit PI) includes exotic-bearing outwash of chiefly volcanic debris (unit Po) and an interbedded primary pumiceous fall deposit from Augustine Volcano. The pumiceous-gravel outwash dips as steeply as $38^{\circ}$ north and northeast, onshore dips implying glacier ice banked against Augustine Island. Adjacent or underlying glacier ice that had supported the deposits melted and caused the beds to settle and rotate to dips steeper than repose angle.

At altitude about $290 \mathrm{~m}$ along Augustine Creek (westmost of the Pleistocene sections), one of the lowest beds of a 


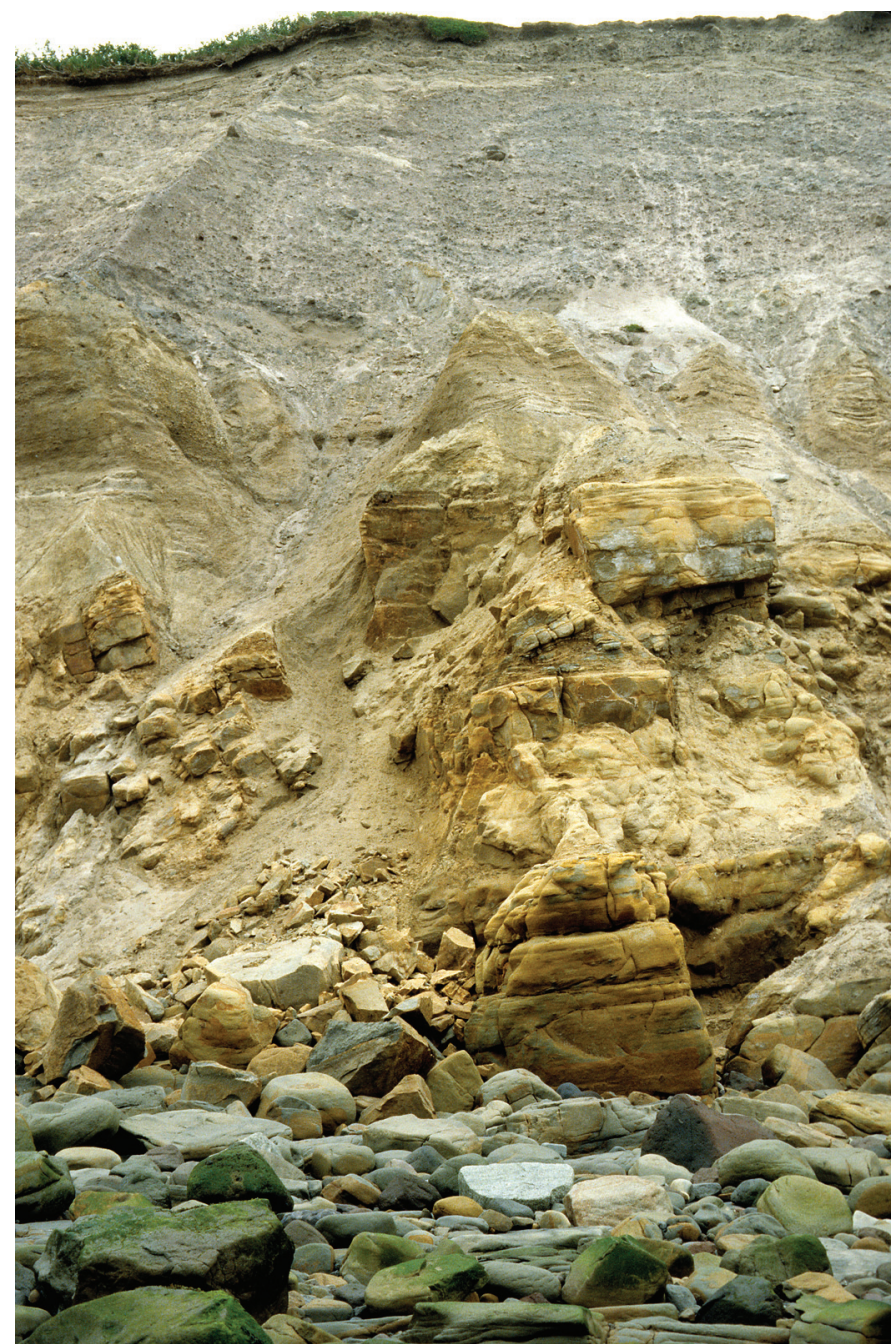

Figure 14. Great landslide block capped by layered Augustine volcanic debris, south coast Augustine Island. (USGS photograph by Richard Waitt.)

section of alternating tephra and pumiceous pyroclastic-flow deposit is waterlaid pumice whose wood and charcoal fragments by two radiocarbon AMS dates precede 39,000 yr B.P. (table 2). This bed is overlain by several thin beds apparently of glacial outwash (containing exotic stones) intercalated with beds of waterlaid(?) pumice sand and gravel, beds overlain in turn by angular pumice gravel (Augustine fall) (fig. 15). Thus some Pleistocene glacial and volcanic materials may predate the late Wisconsin glaciation of Cook Inlet.

Numerous varieties of exotic pebbles, essentially the list above, lie among beach gravel on most shores - northwest, north, east, southeast, and southwest — azimuths no longer with glacial deposits exposed upslope. Constituting no more than 0.2 percent of beach stones, they must have arrived at the coast in debris-avalanche or pyroclastic-flow deposits. The nearly universal distribution of exotic pebbles in modern beach gravel around the island suggests glacial deposits mantled all flanks of Augustine Volcano but postglacial eruptions have since buried all but a few south-flank remnants.

\section{Basaltic and Rhyolitic Deposits}

Several small inliers on Augustine Volcano's south flank (fig. 12) expose dark, basaltic fragmental material bedded in layers 1 to $30 \mathrm{~cm}$ thick (unit Pvb, plate 1) (fig. 16). These beds alternate between medium sand and granule gravel, most of them poorly sorted. Some beds contain much mud-sized material, are yellowish (palagonitic) and tightly cemented. Fragments of porphyritic olivine basalt as large as $20 \mathrm{~cm}$ are scattered through the sections. Most fragments are very angular, but a few are subangular to subround, distinctly abraded. These beds also contain sparse rounded pebbles of sandstone and angular chips of shale, both derived from the Naknek Formation. The basaltic vent is buried but probably lies nearby; the sandstone clasts suggest that the Naknek Formation must at depth extend east of its exposed limits.

A few beds have low-angle cross beds; some laminae contain mud balls (accretionary lapilli) 3 to $8 \mathrm{~mm}$ in diameter, and some beds contain angular bombs as large as $20 \mathrm{~cm}$ whose impact sagged the underlying beds as much as $25 \mathrm{~cm}$. These characteristics, the blocky shape of apparently juvenile clasts, and retention of fine sand and silt in many beds are evidence that external (meteoric) water-vapor was the main propellant in the explosions, and are evidence that at least some of the beds were wet when emplaced. Such deposits are called "hyaloclastite."

Basaltic-hyaloclastite beds at altitude $270 \mathrm{~m}$ on the south flank are underlain by several beds 0.5 to $1 \mathrm{~m}$ thick of nonsorted andesitic sandy pebble-cobble diamict rich in clasts of Naknek sandstone, probably thin pyroclastic flows. The basalt

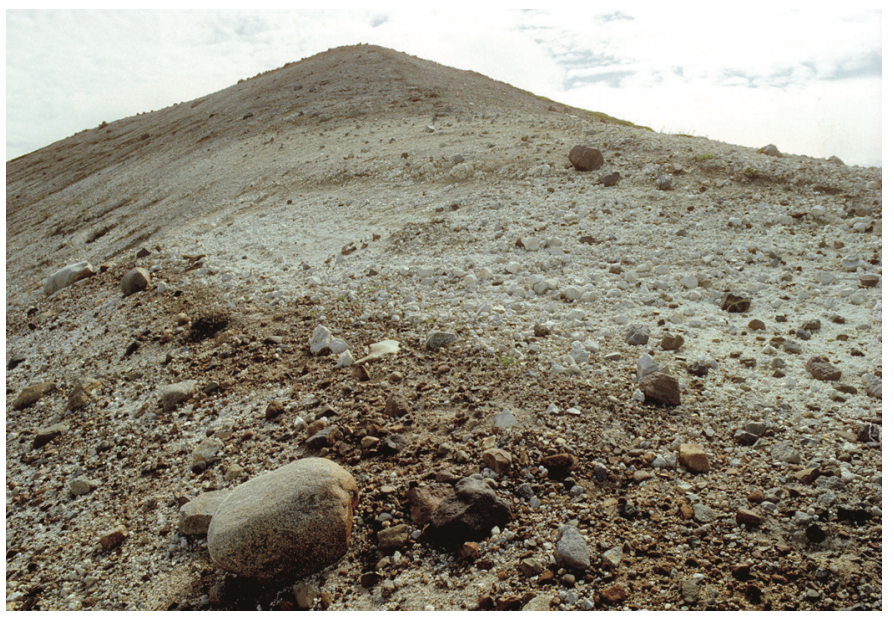

Figure 15. View north of glacial till containing striated exotic stones and associated glacial drift overlain by dacitic fall pumice of Augustine Volcano. Figure 18 photograph shows pit opened just beyond boulder in left-center. (USGS photograph by Richard Waitt.) 


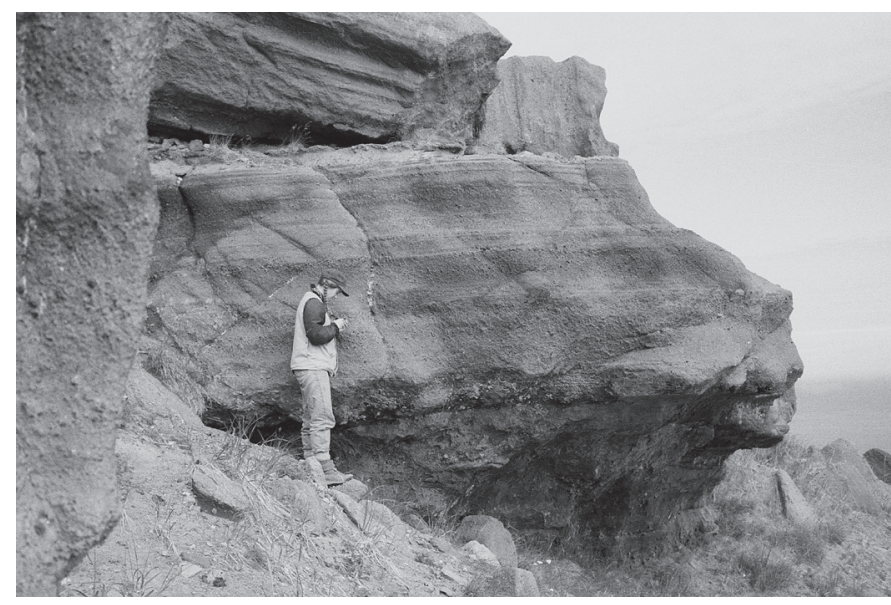

Figure 16. View eastward showing bedded olivine-basalt hyaloclastite at or near base of discontinuously exposed volcanic materials of Augustine Volcano, probably of very late Pleistocene age. (USGS photograph by Richard Waitt.)

eruptions are a brief, extraordinary episode in a volcano erupting andesite before and long afterward. The uppermost $20 \mathrm{~cm}$ of the basaltic hyaloclastite is interlayered with the base of dacitic-rhyolite fall pumice (unit Pvr).

At altitude $310 \mathrm{~m}$ on the south flank, $10 \mathrm{~m}$ of white pumiceous beds (unit Pvr, plate 1) range from openwork, angular pumice pebbles (fall bed) to pebbly sand with subangular pumice clasts (pyroclastic-flow deposit). The lowest pumiceous beds of very coarse sand are interlaminated with the upper $20 \mathrm{~cm}$ of the Pleistocene basaltic-hyaloclastite beds (fig. 17). Thus rhyolitic white pumice erupted from the summit vent more or less simultaneously with olivine basalt from a separate south-flank vent.

In the lowest parts of the westmost inlier sections (azimuth south-southwest, altitude $280 \mathrm{~m}$ ), pumiceous beds overlie and are interbedded with the top of glacial and glaciofluvial deposits that bear exotic stones and from whose base come the radiocarbon dates exceeding 39,000 yr B.P. (fig. 18). Overlying the glacial horizon is $17 \mathrm{~m}$ of sandy flow deposits punctuated by four major pumice-fall beds (unit PHfp; see just below).

\section{Pleistocene and Holocene Pumiceous Fall and Pyroclastic-Flow Deposits}

Exposed on the steeply eroded sides of four south-side nunatak-like inliers at altitudes 250 to $700 \mathrm{~m}$ are sections 8 to $17 \mathrm{~m}$ high comprising several beds of pumiceous and lithic pyroclastic-flow deposits interbedded with many beds of loose, sorted pumiceous fall deposit (unit PHfp, plate 1).

The upper pumiceous fall beds of all these sections probably correlate with tephras $\mathrm{C}$ and $\mathrm{M}$, and perhaps with other tephra beds of the coastal sections. But ambiguous field character and chemical data make such correlation tenuous. At altitude $370 \mathrm{~m}$ on the south-southeast azimuth, an east-facing 17-m section contains seven pumiceous-fall beds, at least five intervening lithic-fall beds, two pumiceous pyroclastic-flow beds, and several sand-ash beds. At $9 \mathrm{~m}$ above base, a peat layer dates by radiocarbon to about 2,160 yr B.P. (table 2). Above it lie five coarse pumiceous tephra layers, which must correlate with the late Holocene coastal tephras. A less complete east-facing section of interlayered thick pumiceous fall and pyroclasticflow beds lies at altitude 460 to $550 \mathrm{~m}$ on the south azimuth.

Augustine erupted at least several times between the late Wisconsin and about $2,200{ }^{14} \mathrm{C}$ yr B.P., but the evidence on Augustine Island is scant. On a few south-flank inliers, pumiceous pyroclastic-flow and several pumiceousfall deposits underlying peat dated to about 2,160 yr B.P. (table 2) represent this broad period. On Shuyak Island

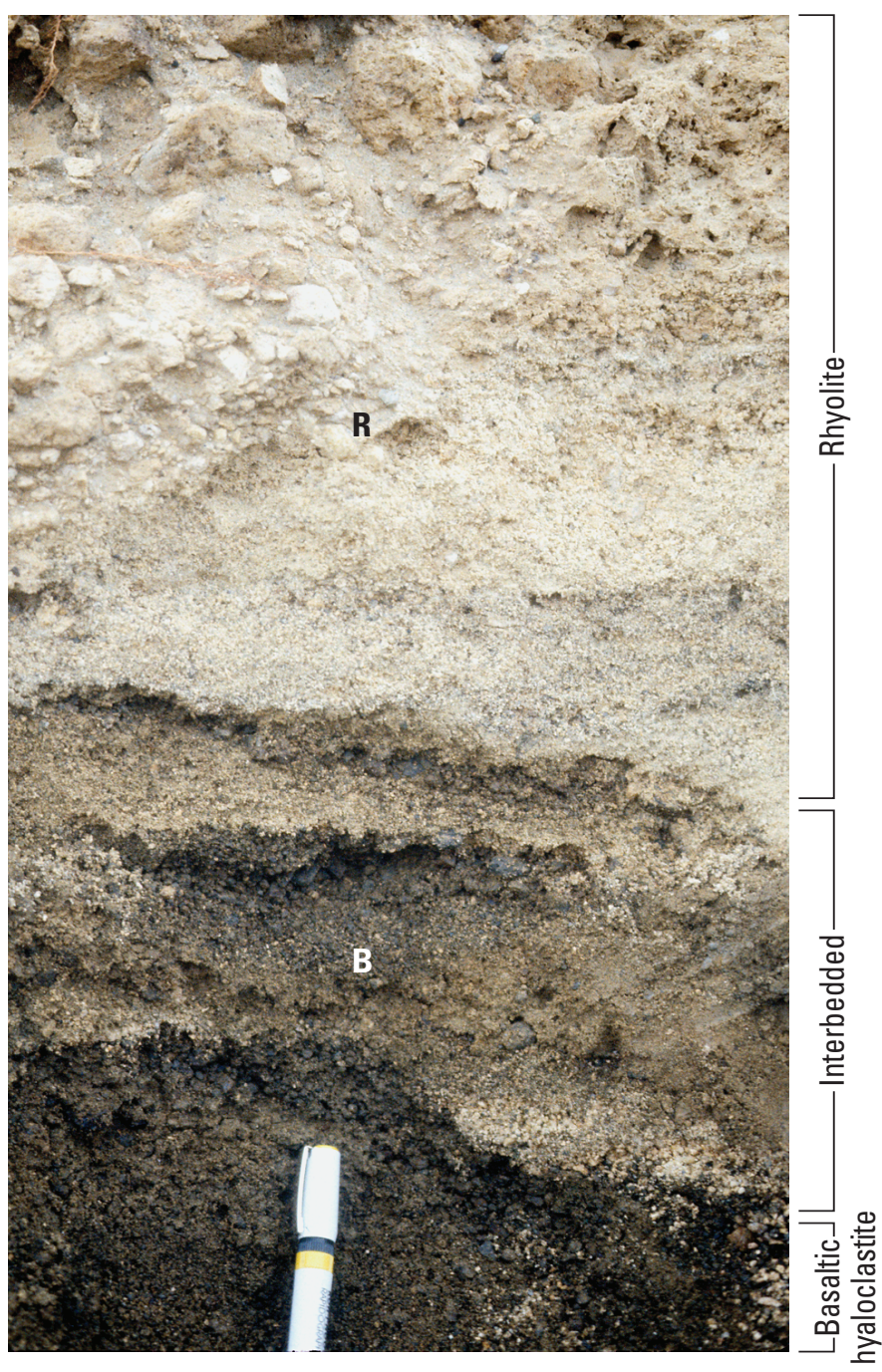

Figure 17. Basaltic hyaloclastite (B) overlain by rhyolitic pumice (R), on south flank of Augustine Island. Top of hyaloclastite is interlayered with thin beds of base of rhyolite. (USGS photograph by Richard Waitt.) 


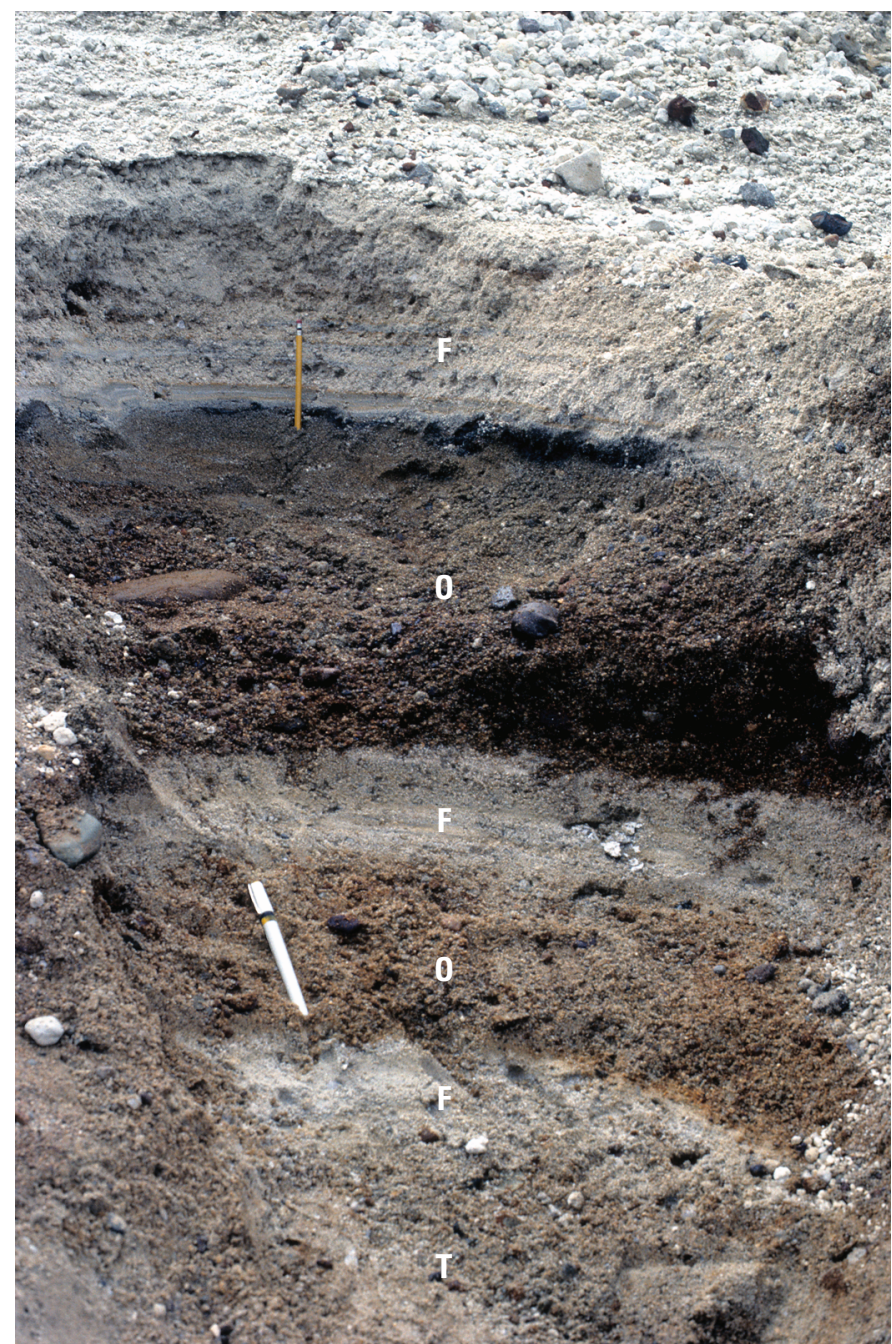

Figure 18. Pumice-fall deposit from Augustine interbedded with distal thin beds of Pleistocene glacial outwash, south-southwest flank of volcano at altitude $155 \mathrm{~m}$. View shows top, layered part of thick bed of coarse till (and outwash?). 0, glacial outwash; T, glacial till; F, Augustine pumiceous fall deposit. For context see figure 15. (USGS photograph by Richard Waitt.)

$110 \mathrm{~km}$ southeast of Augustine (fig. 1A), two fall tephras of Augustine chemical provenance (probe analysis of glass by J.R. Riehle and C.E. Meyer) date between about 6,460 and 5,020 yr B.P.; a higher Augustine tephra there dates between 3,620 and 3,360 yr B.P. (table 2; plate 2, section RBW 93Ko.09) (tephras identified in Riehle and others, 1998). Along Kamishak Creek 70 km southwest of Augustine (fig. $1 A$ ), a fall tephra of Augustine provenance dates between about 3,850 and 3,660 yr B.P. (table 2) (Riehle and others, 1998, fig. 8). A probably Augustinian ash dated to about 2,275 yr B.P. lies near Homer $110 \mathrm{~km}$ northeast of Augustine. Several Augustine tephras probably also of early to middle Holocene age lie on Fortification Bluff 22 km west-northwest of Augustine (J.R. Riehle, written commun., 1996; Riehle and others, 1998). Undoubtedly early and middle Holocene eruptions laid deposits on Augustine Island, but except for the south-flank kipukas-where details of age remain undeciphered - such deposits lie buried beneath voluminous younger eruptive deposits.

\section{Lava Domes of Uncertain Late Holocene Age}

\section{Kamishak Dome (Dome K)}

Kamishak dome, a massive light-gray porphyritic andesite (unit dk, plate 1) forms a conspicuous bump on Augustine Volcano's south flank (figs. 3, 12) at altitude $513 \mathrm{~m}$. It is thickly blanketed by fall and ballistic debris, the only exposure being its steep south (downslope) face. Because even the upper part of the dome seems to be overlain by far less than the 10 to $20 \mathrm{~m}$ of fragmental deposits that lie downslope, it seems to be late Holocene in age.

The cross section (on plate 1) shows its imagined feeder vent at depth $515 \mathrm{~m}$ (sea level) a pipe separate from central pipe. But Kamishak domerock is essentially identical to the cluster of summit domes, its feeder must at depth must flare from the central pipe, implied on the cross section by Kamishak's north plunge with depth.

\section{Domes $\mathrm{F}$ and $\mathrm{P}$}

Two domes of porphyritic gray andesite form bumps at altitudes 1,025 (dome F, unit df, plate 1$)^{5}$ and $910 \mathrm{~m}$ (dome P, unit dp) on the upper northwest flank, some 400 to $800 \mathrm{~m}$ northwest of the central summit-dome complex (fig. 19). The large West Island debris avalanche (table 3) must have left a large crater scar including this area, so the domes must be younger than about 390 yr B.P. (table 2) but precede historical eruptions.

\section{Prehistoric Summit Domes}

Probably several overlapping domes make up the east and south sides of the summit cone. Three are distinguished by variations in overall color separated by shallow moats. Map units $d s_{1}$ through $d s_{3}$ (plate 1$)$ suggest relative ages $\left(\mathrm{ds}_{3}\right.$ youngest as geomorphically it seems to cover the others), but this is rather speculative. Part of the east side is deeply eroded into the "pinnacles," which on a 1909 photograph (Kienle and Swanson, 1980, fig. 10; Swanson and Kienle, 1988, fig. 5) is old rock remaining after a summit collapse during the 1883 eruption. This old dome rock is overlapped by the several historical domes: the south side by the 1964 dome and the west side by 1883 (buried), 1935, and 1964 domes.

\footnotetext{
${ }^{5}$ These domes had been informally called domes "I" and "H" after seismic stations (AUI and AUH) installed on them long ago. But "tephra I" and "tephra H" in the coastal Holocene stratigraphy, also in long and published use and continued here, are in source and time unrelated to the two domes. To avoid confusion the continued dual use of I and $\mathrm{H}$ would cause, the domes are here renamed to dome $\mathrm{F}$ (upper one) and dome $\mathrm{P}$ (lower).
} 


\section{Lava Flows}

Massive porphyritic andesite crops out far below the level of summit and subsummit domes at five sites on the volcano's south and north flanks (unit Id, plate 1). Largely buried by younger fragmental debris, these inliers crop out only in small patches that have diminished even in recent decades. They are far enough downslope to be lava flows and in form they seem not to be large mounds, though the porphyritic andesite is lithologically like that of the domes.

\section{Prehistoric Deposits of Late Holocene Age}

In writing, "describe" means to tell of a thing; in geometry it means to draw an outline of a thing. Here you get both: text and map. Most of Augustine's exposed apron of coarse debris is younger than 2,500 years. Radiocarbon-dated overlying and intercalated pumiceous fall deposits limit the timing and correlation of many coarse deposits (table 2).

Most of the volume of flank deposits is bouldery diamicts of angular clasts, and each diamict is an unsorted, unstratified mixture of angular clasts of all sizes from sand to enormous boulders. Almost all clasts are of sparsely vesicular porphyritic andesite similar to rock of the present dome complex. Many of the coastal diamicts contain rare clasts derived from the middle-lower slopes - from Mesozoic rocks that underlie the south mountain flank, and from Pleistocene glacial deposits.

The dominant eruption style seems to be growth of summit domes followed by collapse as a debris avalanche. Table 3 suggests a significant debris avalanche every 180-200 years average. Similar arithmetic suggests eruptions of coarse pumiceous tephra are spaces about $3 \frac{1}{2}$ centuries average, and eruptions yielding significant ashflows every $3 \frac{1}{4}$ centuries or less.

The "Description of Map Units" on plate 1 explains labeling. Unit IHa, for instance, overlies tephra I and underlies tephra $\mathrm{H}$.

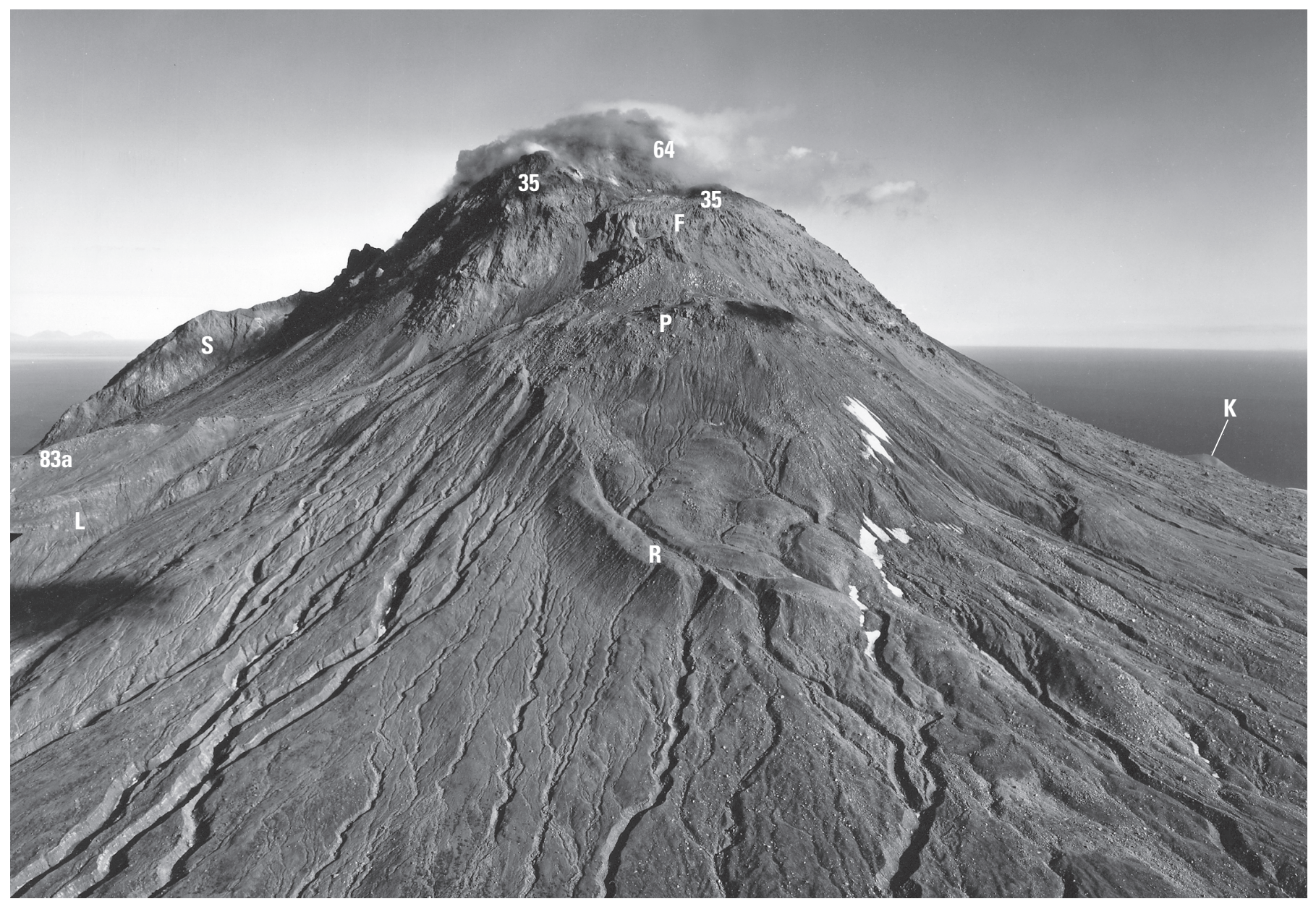

Figure 19. Oblique aerial view toward east-southeast of Augustine summit area including landslide-truncated prehistoric summit-dome complex (S). Off summit area on west-northwest are prehistoric lava domes $F$ and $P$, and below dome $P$ a rubble flow (R). On south flank lies Kamishak dome (K). North flank lava flow (L) overlain by 1883 debris-avalanche levee (83a). Visible in summit area are parts of 1935 lava dome (35) and the newly emplaced 1964 lava dome (64). (USGS photograph by Austin Post, 3 September 1966.) 


\section{Deposits Older Than Tephra G (about 2,500-2,100 ${ }^{14} \mathrm{C}$ yr B.P.)}

\section{East Point ${ }^{6}$ Debris-Avalanche Deposit(s)}

A continuous high sea cliff between Southeast Point and Northeast Point ${ }^{7}$ (fig. $1 B$ ) exposes bouldery diamicts (unit Ga, plate 1) that by color and relation to tephra layers we separate into four units, all apparently deposits of debris avalanche, the youngest overlain by the $\mathrm{H}$ tephra. All are clearly fragmental but contain angular boulders as large as $8 \mathrm{~m}$ and rare shattered megablocks much larger.

A diamict forming the lowest part of this coastal sea cliff for $3 \mathrm{~km}$ along the east coast and named for East Point is at least $13 \mathrm{~m}$ thick, its base not exposed. It contains angular andesite fragments as large as $5 \mathrm{~m}$; on the beach below the sea cliff are wave-winnowed lag boulders as large as $7 \mathrm{~m}$. Large clasts in the sea cliff are set in a gravelly sand matrix of shattered andesite (fig. 20A), generally gray but in places oxidized reddish. Most of the boulder-sized andesite clasts are gray, some are reddish, and a few are highly altered to yellow or white. A few delicate, prismatically jointed clasts must have been hot juvenile dome-rock clasts that cooled after emplacement (fig. 20B).

The lower two-fifths of the bluff near East Point is too covered to assess internal stratigraphy reliably. Within the $17-\mathrm{m}$ section of debris avalanche is one definite break $4 \mathrm{~m}$ above the base of exposure (base of deposit not exposed) and a possible break at $12^{1 / 4} \mathrm{~m}$ above base (see plate 2, section RBW 91A.102). Thus this thick bouldery diamict may actually comprise the deposits of two or more debris avalanches. Some of the substantial field of mostly submerged large boulders (unit ob, plate 1) offshore of the east coast is probably part of these older avalanches.

East Point diamict is capped by the sparsely exposed $\mathrm{G}$ tephra, and that overlain by oxidized Yellow Cliffs bouldery diamict (part of unit Glays).

\section{Deposits Between Tephras G and I (about 2,100-1,800 ${ }^{14} \mathrm{C}$ yr B.P.)}

\section{Yellow Cliffs Debris-Avalanche Deposit}

Overlying the sparsely exposed $\mathrm{G}$ tephra that caps the East Point debris-avalanche deposit is a highly altered and oxidized massive diamict containing angular andesite boulders commonly 1 to $2 \mathrm{~m}$ in diameter, some as large as $3.5 \mathrm{~m}$ (lower part of unit Glays, plate 1). This distinctively yellowish unit

\footnotetext{
${ }^{6}$ Begét and Kienle (1992, table 1, bottom) inadvertently transposed the names East Point and Yellow Cliffs debris avalanches. East Point deposit indeed lies below tephra G, Yellow Cliffs deposit above tephra G.

${ }^{7}$ Local place names in this section-East Point, Yellow Cliffs, Southeast Point, and Northeast Point - are all informal. See figure $1 B$ for the distinction of formal and informal place names. This paper prints informal names, like the formal ones, with capitals for clarity in reading.
}

5 to $9 \mathrm{~m}$ thick forms the middle to upper part of the sea cliff for at least $2.5 \mathrm{~km}$ along the east coast (fig. 21). The matrix and large clasts alike are strongly altered to soft zeolite (?) and clay. But the unit also contains sporadic pods meters in diameter of gray to reddish coarse diamict of scarcely altered andesite. Midway between East Point and Northeast Point its surface shows sharp local relief of 3 to $4 \mathrm{~m}$ where directly buried by the Northeast Point debris-avalanche deposit. At and south of Southeast Point, the Yellow Cliffs diamict is overlain by the gray Southeast Point debris-avalanche deposit, which is capped by tephra I.

The hummocky surface topography and the massive and coarse texture clearly identify the Yellow Cliffs diamict as a debris-avalanche deposit. The enclosed pods of unoxidized diamict and the fact that the unit is both overlain and underlain by unoxidized to weakly oxidized similar diamicts show that the strong alteration had occurred in the source area, before the avalanche. Apparently most of the avalanche is of summit dome rock that had become strongly altered by hydrothermal fluids before the avalanche occurred.

\section{Southeast Point Debris-Avalanche Deposit}

Overlying the Yellow Cliffs diamict and beneath tephra I along the coastal cliff $350 \mathrm{~m}$ west of Southeast Point lies a diamict at least $8 \mathrm{~m}$ thick with in-situ boulders as large as $3.5 \mathrm{~m}$ (fig. 22) (upper part of unit Glays, plate 1), winnowed boulders on the beach below reach $7.5 \mathrm{~m}$. The angular clasts and most of the matrix are gray to reddish and scarcely altered, contrasting with the underlying Yellow Cliffs diamict. The Southeast Point debris-avalanche deposit extends at least 2.5 $\mathrm{km}$ northeast along the coastal cliffs to Northeast Point, where it is also overlain by the I tephra. The I tephra is overlain in turn by the Northeast Point debris-avalanche deposit (unit $\mathrm{IHa}$ ). Surface slope atop the sea cliff, if projected seaward, indicates that the Southeast Point debris-avalanche deposit has been wave eroded back at least 0.5 to $1.0 \mathrm{~km}$. Figure 23 schematically shows relations among four debris-avalanche deposits - two of this map unit, one of the underlying unit, one of the overlying unit.

The south part of the offshore belt of mostly submerged large boulders (unit ob, plate 1) is of this eroded-back avalanche.

\section{Deposits Between Tephas I and $\mathbf{H}$ (about $1,700-1,400{ }^{14} \mathrm{C}$ yr B.P.)}

\section{Northeast Point Debris-Avalanche Deposit}

Beneath the $\mathrm{H}$ tephra and 1.5 to $3 \mathrm{~m}$ of underlying sand ash, a coarse and massive diamict extends along the coast for more than $4 \mathrm{~km}$ from north of Northeast Point to south of East Point (unit IHa, plate 1). The deposit contains very angular boulders of gray andesite typically as large as 5-7 m in intermediate diameter but the largest $12 \mathrm{~m}$, some of them 

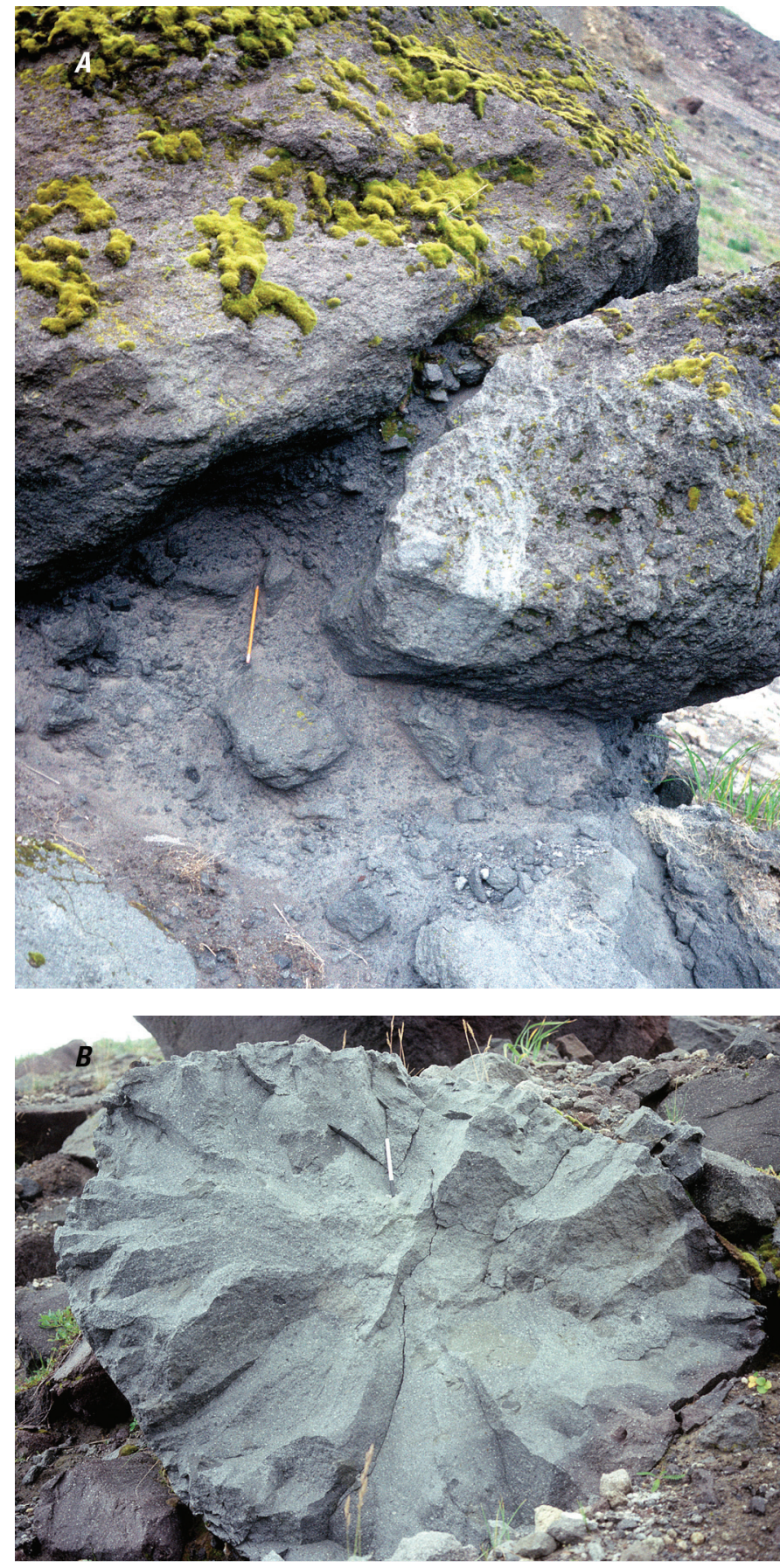

Figure 20. Details within East Point debris-avalanche deposit. $A$, Close view of shattered-andesite matrix of debris avalanche. $B$, Radially, prismatically jointed porphyritic andesite block. Radial joints signify that block was hot when emplaced, evidence of eruption in progress or of eruption triggered by the developing landslide. (USGS photographs by Richard Waitt.) are internally shattered, set in a gravelly sand diamictic matrix with smaller clasts of identical composition and angularity. At East Point the deposit is at least $20 \mathrm{~m}$ thick (base not exposed); it tapers $1 \mathrm{~km}$ south of East Point to $10 \mathrm{~m}$ thick and in another $0.5 \mathrm{~km}$ to $7 \mathrm{~m}$ thick, where it overlies a thin pyroclastic-flow deposit. Within a few hundred meters farther south it pinches out altogether. Its south part overlies three (or more) older debris-avalanche deposits (fig. 23). Coarse, rubbly diamict with boulders as large as $4 \mathrm{~m}$ crops out upslope in the walls of incised gullies, traceable apparently up to the base of the summit dome complex at altitude $700 \mathrm{~m}$.

Within a kilometer of the coast the surface is broadly hummocky, having a relief generally of $3 \mathrm{~m}$ but much higher over distances of $50 \mathrm{~m}$ (figs. 24, 25). A straight levee 3-8 m high delineates the north side of the main body of deposit. But similarly hummocky, bouldery deposit also lies north of (outside) this levee. This too may be part of the Northeast Point debris avalanche, emplaced just before the leveeforming phase. Mantling tephra and peat, $3 \mathrm{~m}$ and more thick, have considerably smoothed this topography. But beneath this mantle in coastal exposure its sharp local relief is at least $6 \mathrm{~m}$ over distances of $20 \mathrm{~m}$. A few boulders larger than $2.5 \mathrm{~m}$ in the top of the deposit protrude through the tephra-peat blanket. The upslope margin of the debris-avalanche deposit is widely buried by 1976 (and prehistoric?) pyroclastic-flow deposits at least $80 \mathrm{~cm}$ thick.

About $0.8 \mathrm{~km}$ south of Northeast Point the upper part of this diamict is strikingly monolithologic. Every fragment is very angular, most of them pebble size and coarser. Here the deposit appears to be a single dome block at least $30 \mathrm{~m}$ long; it is more disaggregated than so-called "jig-saw" blocks in the 1980 Mount St. Helens avalanche deposit described by Glicken (1996), yet it did not dilate and disaggregate enough to form or admit "matrix." This more-or-less-intact block, far too large to have been moved by pyroclastic flow or lahar, could only have piggybacked atop a moving avalanche.

At Northeast Point the deposit crosses a straight eastfacing coastwise scarp $650 \mathrm{~m}$ long and $30 \mathrm{~m}$ high that lies about $450 \mathrm{~m}$ back from the sea (fig. 26, plate 1). This scarp apparently is a sea cliff cut back into the Yellow Cliffs (and older?) debris-avalanche deposits. Seemingly identical hummocky coarse debris lies both behind and in front of the scarp, and the overlying tephra section (lowest pumiceous tephra is H) is the same both sides of the scarp. The Northeast Point debris avalanche must have overridden and buried the scarp, though not so thickly to obliterate (fig. 10B). The material atop the buried sea cliff is delicately hummocky (fig. 26), apparently stranded. This material could not itself be older and overridden by the seaward debris forming Northeast Point, for that would have smoothed and fluted the scarp-like the scarp behind West Island debris-avalanche deposit (see below).

Nearly continuous boulders, some as large as $5 \mathrm{~m}$, extend at least $600 \mathrm{~m}$ offshore of Northeast Point (unit ob, plate 1). Storm waved have eroded the original subaerial deposit back at least that far, to its present sea cliff. 
Figure 21. View of sea cliff along Augustine Island east shore showing Yellow Cliffs debris-avalanche deposit (Y) overlain by Northeast Point debris-avalanche deposit (N). Colluvium covers East Point debris-avalanche deposit (E). (USGS photograph by Richard Waitt.)

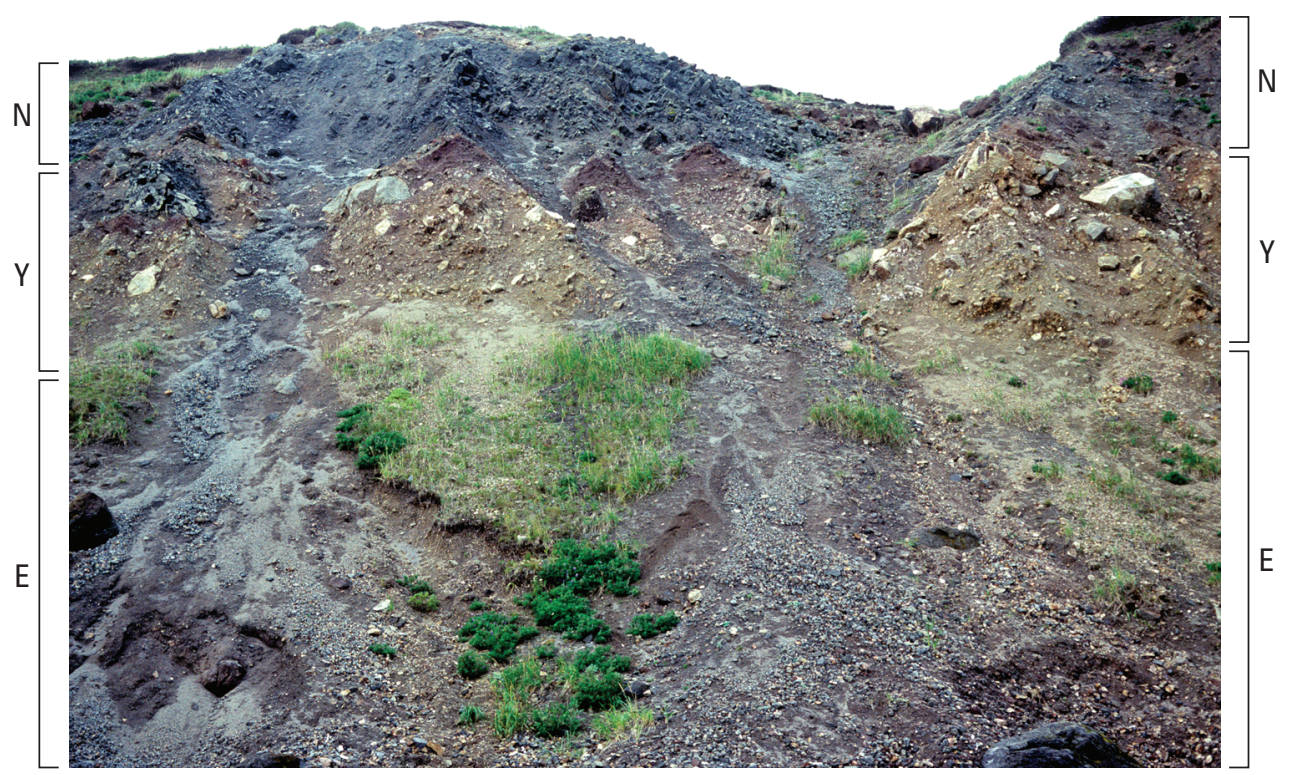

Figure 22. Southeast Point debrisavalanche deposit (S) overlain by tephra I (at man), in turn overlain by Northeast Point debris-avalanche deposit (N). East coast of Augustine Island. (USGS photograph by Richard Waitt.)
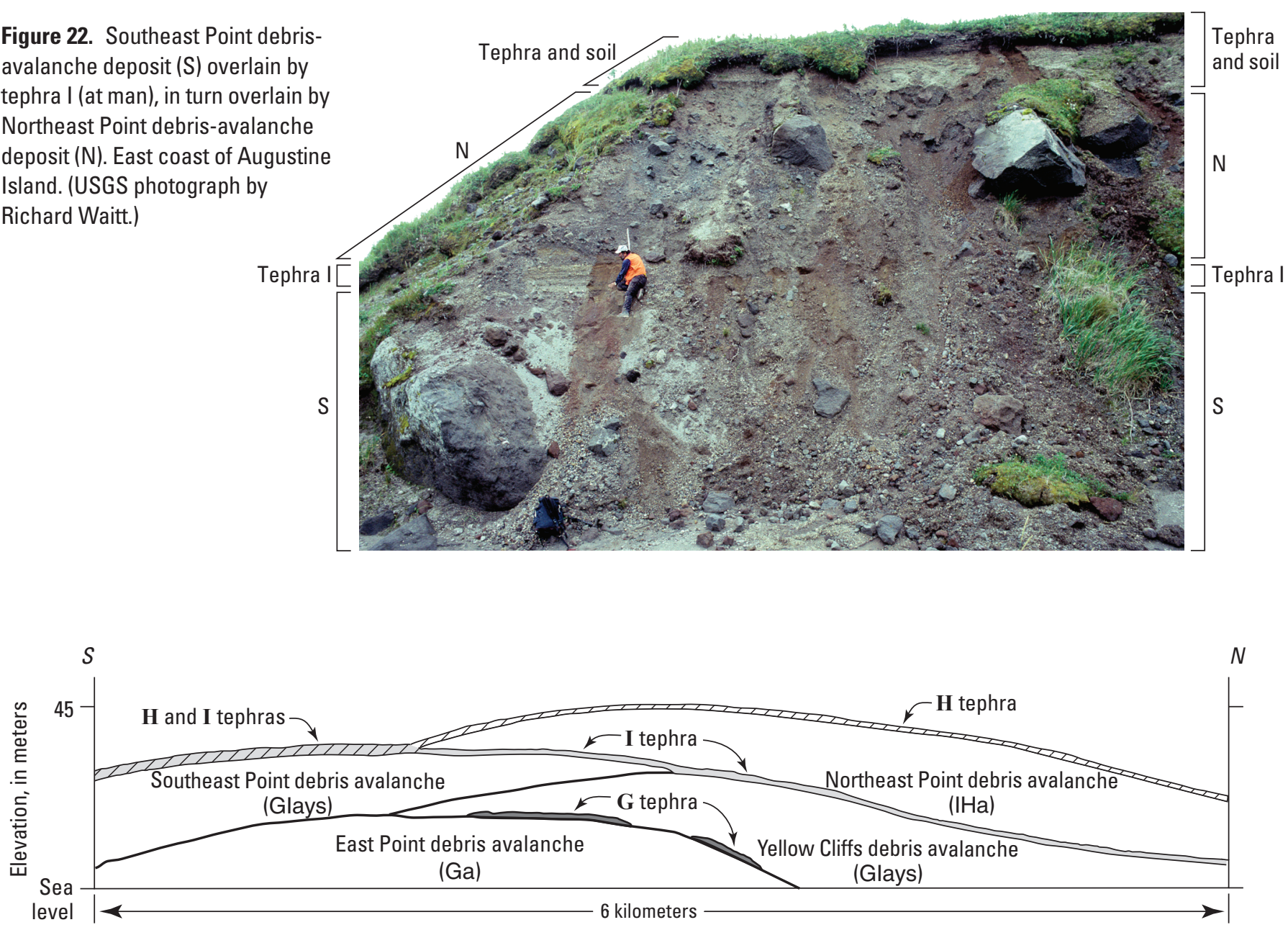

Figure 23. Schematic sketch of coastal cliffs along east side of Augustine Island showing stratigraphic relations of four oldest debrisavalanche deposits (d.a.) and the three oldest of the coarse pumiceous-tephra marker beds (G, I, H). Map-unit labels (of plate 1) in parentheses. 
Figure 24. View west of hummocky surface of Northeast Point debrisavalanche deposit. Hummock in right middle distance is about $18 \mathrm{~m}$ high. Its top holds the benchmark "mound." In distance, cone of Augustine Volcano, its top in clouds. (USGS photograph by Richard Waitt.)

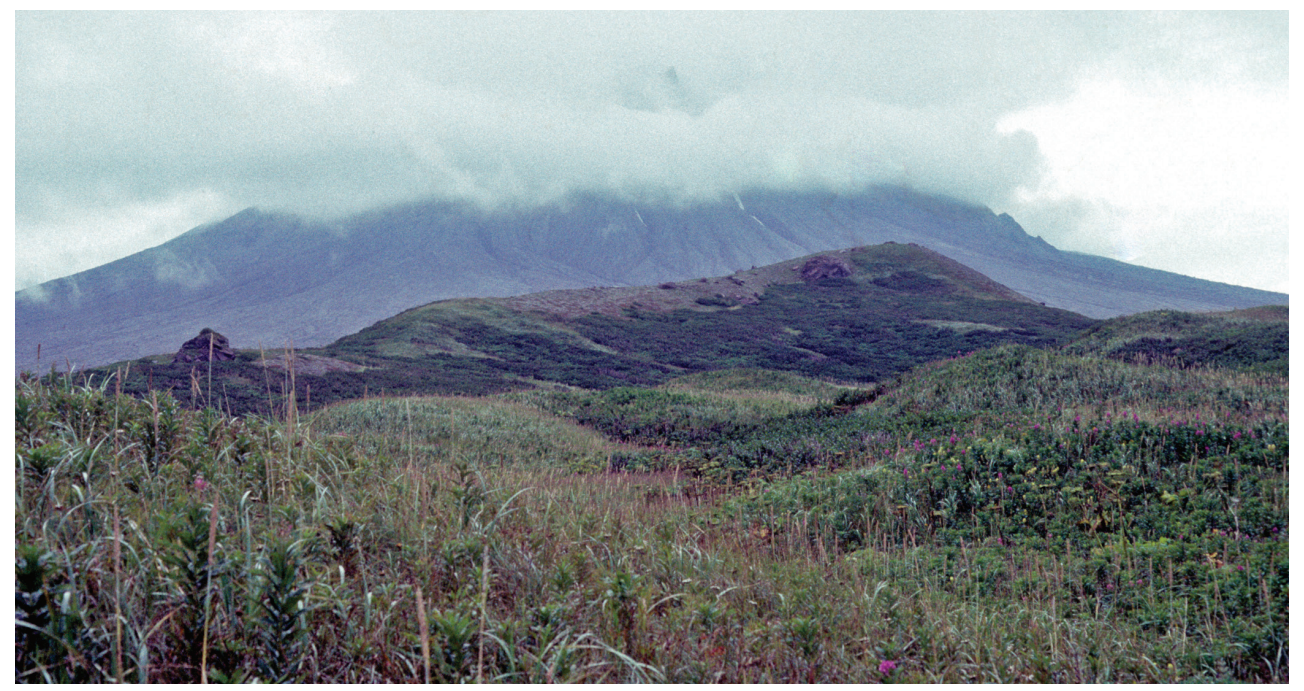

\section{Northeast Bench Debris-Avalanche or Lahar Deposit}

A bouldery gravel diamict (unit IHI, plate 1) containing angular porphyritic andesite stones as large as $4 \mathrm{~m}$ lies outside (north of) the levee that delineates the north side of main body of Northeast Point debris-avalanche deposit (unit IHa). The seaward part of this seemingly continuous unit north of the levee is relatively nonhummocky and called here Northeast Bench. By this morphology the unit underlying the bench would seem to be a lahar deposit (unit IHI). But more than $200 \mathrm{~m}$ back from the sea cliff the area outside the levee is nearly as hummocky as that inside (south of) the levee; thus we map that area with unit IHa. Both map units $\mathrm{IHI}$ and $\mathrm{IHa}$ are overlain by a tephra sequence having tephra $\mathrm{H}$ near its base.

Sandy gravel lacking large blocks underlies tephra $\mathrm{H}$ (tephra I absent) at several places on southeast and south coast. Besides the debris avalanche, this eruption thus seems to have generated voluminous south-side lahars, since cut back to sea cliffs.

\section{Diamict atop Landslide Block}

A massive diamict as thick as 20 meters containing angular clasts as large as 4 meters (unit IHla, plate 1) overlies the west end of the big south-coastal landslide block (unit PI) and overlying Pleistocene glacial till and outwash interfingered with eruptive products (units $\mathrm{Pg}$ and $\mathrm{Po}$ ). The diamict's massive, unstratfied matrix rich in smaller angular clasts and the coarse size of the largest ones suggest its origin by debris avalanche. But in the central and east part of the 800-meter-long exposure, the matrix is in places slightly bedded and the enclosed stones smaller, more like lahar. This whole deposit underlies tephra $\mathrm{C}$ and in places tephra $\mathrm{H}$ (see plate 2, section RBW 91A.20). By its tephra-bracketed age, this flow could be a small west tongue

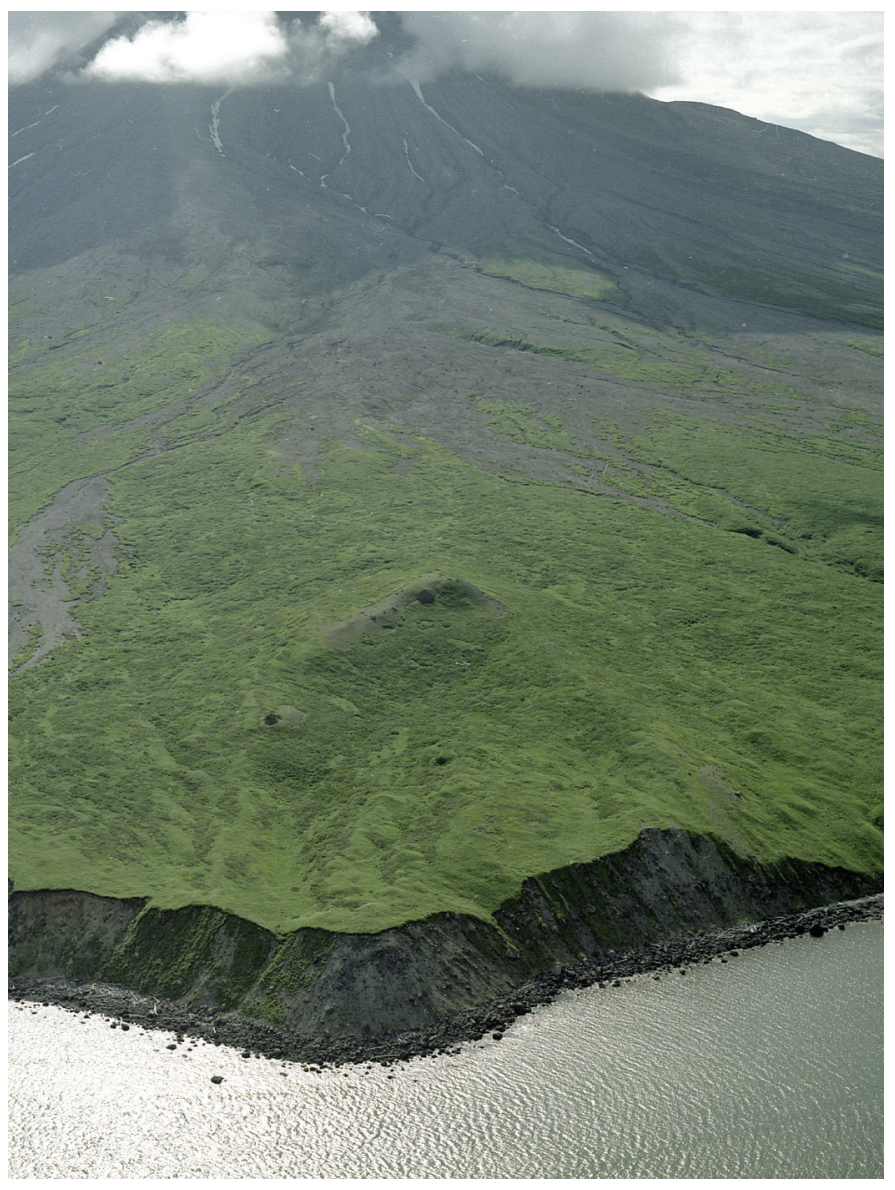

Figure 25. Oblique aerial view, Augustine Island. This point is $0.8 \mathrm{~km}$ south of bold Northeast Point; sea cliff is $35 \mathrm{~m}$ high. Hill in lower center is "mound" shown from ground in figure 24. (USGS photograph by Richard Waitt.) 
of the huge Northeast Point debris avalanche that mostly flowed east of the south-flank's high of Jurassic sandstone.

\section{Deposits Between Tephras H and C (about 1,450-1,100 ${ }^{14} \mathrm{C}$ yr B.P.)}

Several bodies of coarse bouldery diamict lie along the lower slopes and in coastal exposures at azimuths southwest, south, and southeast from Augustine's summit. They are all capped by tephra $\mathrm{C}$ but seemingly not by tephra $\mathrm{H}$. Two are hummocky, evidently debris-avalanche deposits. Another, also very coarse, is nonhummocky and microlobate and evidently not a great avalanche (southeast fan). These separated deposits all may be close in age, but by the bracketing tephra layers they are dated only within a range spanning about four centuries.

\section{South Point Debris-Avalanche Deposit}

South Point, jutting $600 \mathrm{~m}$ seaward from the south coast, consists of a diamict of angular clasts of porphyritic andesite as much as $9 \mathrm{~m}$ in intermediate diameter (unit HCas, plate 1). Its hummocky surface has local relief of $10 \mathrm{~m}$. Clearly a debris-avalanche deposit, it has no evident levees upslope, where it has been deeply buried by younger eruption deposits, especially in 1963-64.

Like the geomorphic relation at Northeast Point, the surface of South Point debris avalanche seems to be a depostional feature rather than an erosional one. A conspicuous seaward step across the surface lies $200 \mathrm{~m}$ back from South Point. The hummocky surface topography in front of this step seems identical to that behind. Geomorphically the step resembles an overridden, partly buried a sea cliff at at Northeast Point. But unlike Northeast Point, it doesn't align with a demonstrably old sea cliff, nor is there older deposit exposed either east or west of South Point. The step may be primary topography of emplacement. The 1980 debris avalanche at Mount St. Helens has two large steps along its length.

South Point debris-avalanche deposit is at least $30 \mathrm{~m}$ thick, the height of the modern sea cliff. That South Point is much broader and projects farther seaward than Northeast Point geomorphically suggests its relative youth, consistent with the tephra $\mathrm{H}$ lacking in the overlying stratigraphy.

The tephra-and-peat sequence that overlies the debrisavalanche deposit ranges from nil to $8 \mathrm{~m}$ thick, typically 1 to $2 \mathrm{~m}$ thick, having the $\mathrm{C}$ tephra near its base. This is the youngest of the large debris avalanches forming Augustine's south and east coast. Yet it too is eroded back into a high cliff, and thus is geomorphically older than any of the weakly cliffed and uncliffed debris-avalanche deposits on the northwest and north coasts.

\section{Long Beach Debris-Avalanche Deposit}

A hummocky diamict is sparsely exposed in the distal southwest quarter of Augustine Island (unit HCal, plate 1). It

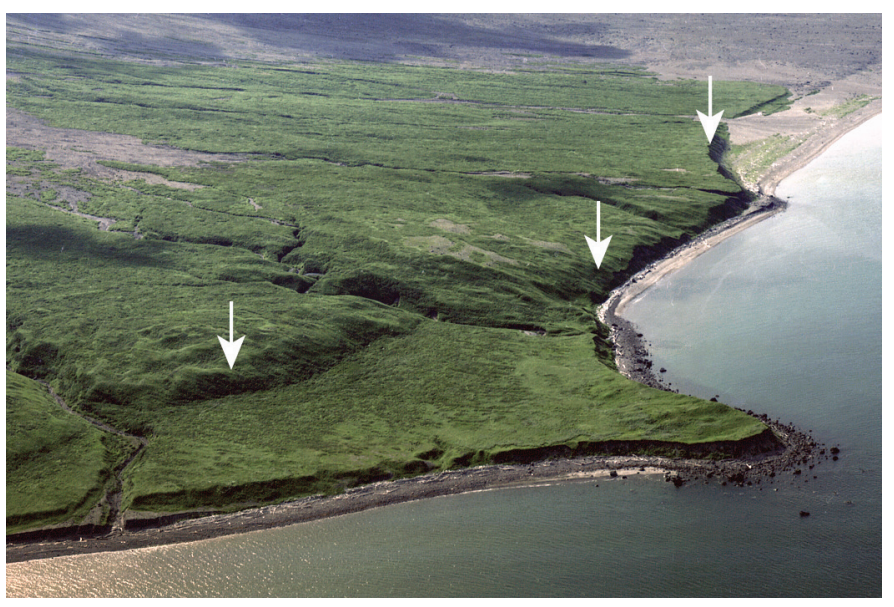

Figure 26. Oblique aerial view west-northwestward of Augustine's Northeast Point debris-avalanche deposit and apparently overridden sea cliff (arrows). Hummocky diamict mantles both sides of scarp. (USGS photograph by Richard Waitt.)

protrudes as irregular rocky mounds through 1976 and older pumiceous lahar deposit and as a belt of hummocks just beyond the limit of 1976 deposits. The hummocks are as much as $9 \mathrm{~m}$ high and $20 \mathrm{~m}$ in diameter. One of the largest consists mostly of one 9-m andesite boulder (fig. 27). Numerous large boulders protruding through swampy terrain near the southwest coast probably are of this deposit. A lithic diamict exposed along Long Beach also includes hummocks exposing boulders as large as $6 \mathrm{~m}$, capped by tephras $\mathrm{C}$ and $\mathrm{M}$. Large boulders lie in matrix of smaller angular material of identical composition, most lithic clasts being porphyritic andesite. But a few clasts are sandstone: this avalanche must have flowed down across now-buried Jurassic sandstone west of current outcrops.

In the southwest quarter 0.6 to $1.0 \mathrm{~km}$ back from the south coast, a swamp nearly at sea level is devoid of large hummocks but interrupted by large boulders. This low area suggests that the debris avalanche had enough momentum that most of it swept to sea. This low, swampy area is not unlike a low area behind hummocks of the 1883 debris avalanche now largely filled by younger flows (see below). Both of these are analogous to Northwest Lagoon behind West Island (see below). Younger pyroclastic and laharic deposits, including from 1935, 1964, and 1976 eruptions, have largely filled the former southwest low.

At low tide and on aerial photographs, large-boulder lag can be seen as far as $0.5 \mathrm{~km}$ off the south-southwest shore (unit ob, plate 1); maps show convoluted bathymetric contours extending to a depth of $10 \mathrm{~m}$ as far as $2 \mathrm{~km}$ offshore, some $8.5 \mathrm{~km}$ from the summit. Similar submarine hummocky topography extends generally 2 to $4 \mathrm{~km}$ outboard of demonstrable debris-avalanche deposits on other azimuths and must record the seaward extent of debris avalanches (fig 11). The muchburied Long Beach debris-avalanche deposit thus seems to extend a similar distance from the summit cone as the younger and well-preserved West Island debris-avalanche deposit. 
Figure 27. Nine-meter megaclast of summit-dome porphyritic andesite forming a single hummock of Long Beach debris-avalanche deposit on lower southwest flank of Augustine Island. (USGS photograph by Richard Waitt.)

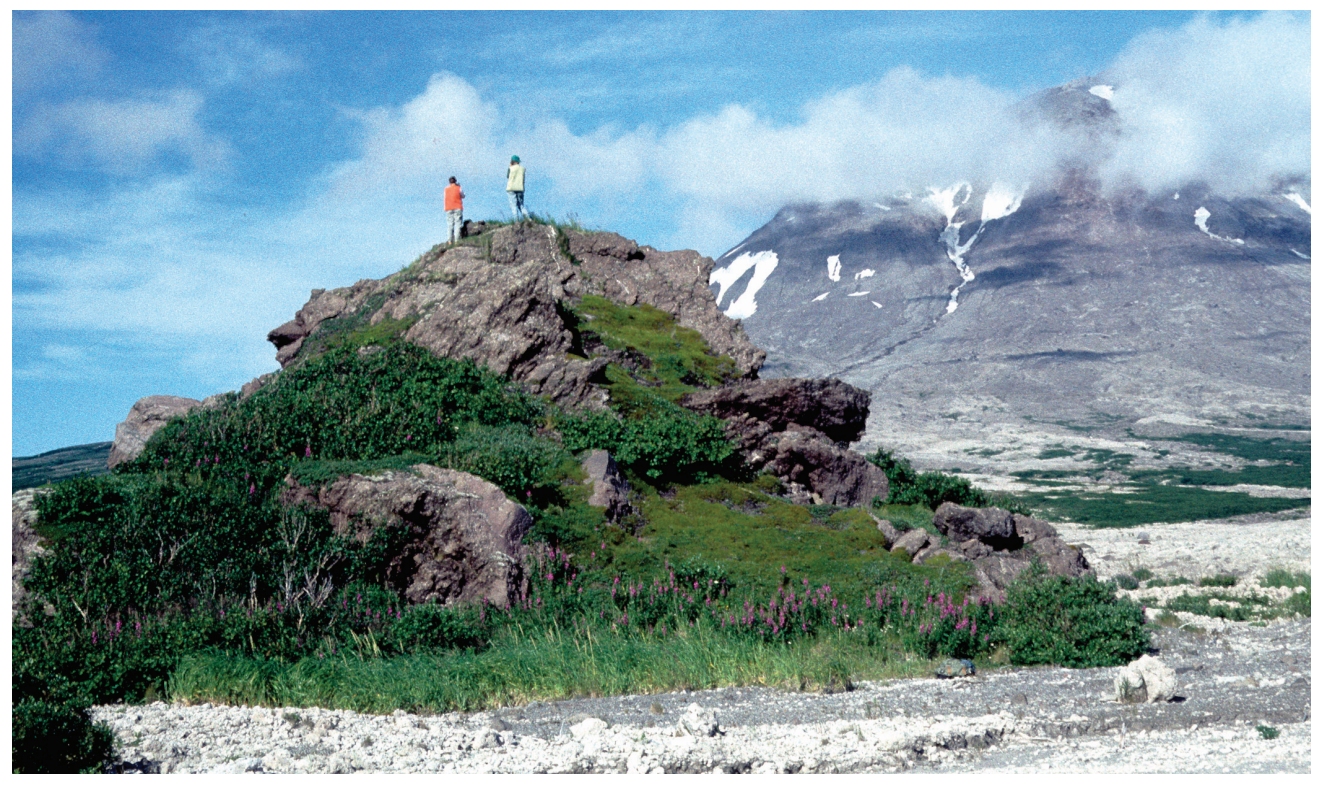

Long Beach debris-avalanche deposit (unit $\mathrm{HCal}$ ) is perhaps only slightly older than the overlying pumiceous deposit (southwest pyroclastic fan, unit HCpwp), for along the eastern part of Long Beach the pumiceous deposit directly overlies the diamict, whose top lacks evidence of weathering or soil.

Long Beach debris avalanche, like South Point debris avalanche, is overlain by tephra $\mathrm{C}$ but evidently not tephra $\mathrm{H}$. These two avalanches could be arms of one large avalanche or may instead be two separate avalanches during the four centuries between the fall of the two marker tephras. Only further refinements of stratigraphy and dating will tell.

\section{Southwest Pyroclastic Fan}

\section{Lithic Pyroclastic-Flow Deposit}

A steep fan of angular-boulder gravel of flow-banded andesite on Augustine's southwest flank heads at altitude $390 \mathrm{~m}$ and extends downslope $2.5 \mathrm{~km}$ to altitude $25 \mathrm{~m}$ (unit $\mathrm{HCpwl}$, plate 1). The boulders are commonly as large as $4 \mathrm{~m}$ in intermediate diameter, rarely to 6 and even $9 \mathrm{~m}$. (Perhaps these largest are of underling Long Beach avalanche and merely surrounded by this gravel fan.) Matrix-bearing debris, or in places 1- to 3-m boulders piled atop one another upslope of huge boulders. Therefore small-bouldery flow continued after the huge clasts had grounded. Many close-spaced levees and numerous intricately lobate margins embellish the surface of the deposit.

The huge boulders suggest an origin by debris avalanche like other deposits lower on all flanks of the volcano. But the steeper surface of this deposit, its intricately leveed surface on aerial photographs, and its lack of conical high-relief hummocks all show it to be a pyroclastic-flow deposit, though lithic. This unit is similar to similarly aged unit HClp on the southeast flank, which contains a few prismatically jointed blocks showing that deposit was shed from a hot-dome source. This deposit (and unit $\mathrm{HClp}$ ) also has many characteristics of laharic debris flow, though their sheer areal extents and volumes argue against lahar (see discussion under heading "Geomorphology").

This fan is capped very sparsely by tephra $\mathrm{C}$ and semicontinuously by tephra $\mathrm{M}$ as thick as $75 \mathrm{~cm}$. The fact that tephra $\mathrm{C}$ is so thin and spotty atop this deposit but is as thick as $29 \mathrm{~cm}$ at the nearby coast suggests this lithic fan was emplaced late during the accumulation of tephra $\mathrm{C}$.

The toe of this lithic deposit is partly buried by much gentler sloping pumiceous pyroclastic-flow deposit (unit HCpwp), which flowed down a deep swale just east and spread clockwise along the coast. Along the steep coastal exposures, lithic gravel - probably distal unit HCpwl (in vertical projection outcrop is too narrow to map on plate 1) - widely underlies the pumiceous pyroclastic-flow deposit.

To the east a lithic gravel diamict prominently capped by tephra $\mathrm{C}$ lies at the coast about the mouths of East Kamishak and Augustine Creeks. This deposit is not hummocky but contains large boulders, its emplacement mode debatable. Possibly it is a thin west tongue of South Point debris avalanche. This flow, mapped with unit $\mathrm{HCpwl}$, had momentum to ride $25 \mathrm{~m}$ up over a coastal landslide block. This relation suggests that flow velocity just before runup was at least $20 \mathrm{~m} / \mathrm{s}$. Such speed suggests debris avalanche more than pyroclastic flow.

\section{Pumiceous Pyroclastic-Flow Deposit}

In coastal cliffs of the southwest volcano flank a massive sandy pumiceous pyroclastic-flow deposit (unit HCpwp, plate 1) as thick as $16 \mathrm{~m}$ overlies the Long Beach debris-avalanche deposit and an associated lahar deposit (units $\mathrm{HCal}$ and $\mathrm{HCl}$ ), and it directly underlies tephra $\mathrm{C}$. The pumiceous pyroclastic deposit is about 80 percent sand matrix; among the coarser clasts three-quarters are pumice and one quarter lithics as large as $5 \mathrm{~cm}$ 
(rarely $30 \mathrm{~cm}$ ). The deposit is graded by density: pumice clasts are concentrated in the upper $3 \mathrm{~m}$ of deposit, lithic clasts in the lower $10 \mathrm{~m}$, though lithics lie sparsely throughout the deposit. The upper $3 \mathrm{~m}$ of the deposit is pale red, oxidized by high temperature. One site reveals two massive deposits - a lower one $13 \mathrm{~m}$ thick with openwork gas-escape pipes and an upper one $4 \mathrm{~m}$ thick - separated by $20 \mathrm{~cm}$ of apparently fluvial deposit lacking a paleosol. These two flows probably followed Augustine Creek and spilled through a western swale.

This sand-ash (unit HCpwp) is the largest and thickest pumiceous pyroclastic-flow deposit known on Augustine Island. Thinner pumiceous and lithic pyroclastic-flow deposits locally underlie it. This pumiceous deposit apparently partly buries the toe of the upslope lithic-pyroclastic deposit (unit $\mathrm{HCpwl}$ ).

\section{Southeast Pyroclastic Fan}

On Augustine Island's south-southeast coast a set of pumiceous pyroclastic-flow deposits (unit $\mathrm{HCpe}$, plate 1) is exposed only in section in lower parts of the sea cliff. Farther east at Southeast Point a lithic pyroclastic-flow deposit (unit $\mathrm{HClc}$ ) consists of cobble gravel to sandy cobble gravel that is vaguely stratified and lacking in large boulders, suggesting a pyroclastic-flow or perhaps laharic deposit. Correlated with this is similar lithic debris capped by tephra $\mathrm{C}$ at and east of the mouth of Middle Kamishak Creek $3 \mathrm{~km}$ farther west.

Upslope from Southeast Point, a proximal facies (unit $\mathrm{HClp}$ ) contains numerous angular lithic (dense) porphyriticandesite boulders 4 to $6 \mathrm{~m}$ across, a few as large as $9 \mathrm{~m}$ (fig. 28). Some smaller dense blocks are prismatically jointed, showing that the flow originated from hot dome rock. Several close-paired levees trend downslope, and from them extend small, multilobate convex-downslope ridges. The deposit is unhummocky, its local relief only $2.5 \mathrm{~m}$ and less. This is the morphology of lithic pyroclastic flow, not of debris avalanche. The short distance (2.2-3.2 km) and steep slope $\left(24^{\circ}\right)$ between the summit and the deposit accounts for the unusually large blocks (for a pyroclastic-flow deposit). The deposit is almost continuously vegetated, much of it by alder. Distal tatters of 1976 pumiceous pyroclastic flows overlap the head of deposit.

This coarse lithic deposit resembles lithic unit $\mathrm{HCpwl}$ on the southwest flank. Emplaced at about the same time, the two probably originated similarly. Both the coastal and the proximal facies are overlain by tephra $\mathrm{C}$, the coastal facies underlain by tephra $\mathrm{H}$.

\section{North Bench Debris-Avalanche Deposit}

North Bench diamict, at least as thick as $15 \mathrm{~m}$, comprises angular fragments as large as $5 \mathrm{~m}$ and bears a mildly hummocky topography with sparse local relief of $6 \mathrm{~m}$. The diamict is surely a debris-avalanche deposit (unit IMan, plate 1) but its surface relief vastly subdued by pyroclastic-flow deposit, and possibly by overwash by tsunami, that have filled lows between hummocks.
The deposit is truncated by a gently convex-seaward sea cliff as high as $23 \mathrm{~m}$, the highest topographic feature along Augustine's northwest coast (figs. 29, 30). This cliff is now isolated 340 to $460 \mathrm{~m}$ from the sea by younger deposits that descended intervening gullies, built seaward-sloping fans, and spread along the coast-burying the former lower third of the sea cliff (fig. 10C; plate 1). And so geomorphically North Bench diamict is much older than neighboring debrisavalanche deposits (described below) that nearly surround the arrested sea cliff that had cut back into North Bench.

If we compare North Bench to debris-avalanche deposits on the east and south coasts, the gently arcuate sea cliff of moderate height well back from the present coast shows the North Bench deposit to be geomorphically as old as the interval between tephras H and C (like South Point avalanche), between tephras I and H (like Northeast Point avalanche), or even older (like Southeast Point avalanche).

Unfortunately for stratigraphy, this northwest flank is statistically upwind, the least likely direction to accumulate tephra ejected from Augustine's summit (fig. 5), and there's no evidence that tephra $\mathrm{M}$ or any of the older tephras reached this far northwest (fig. 7). Most of the area being underlain by

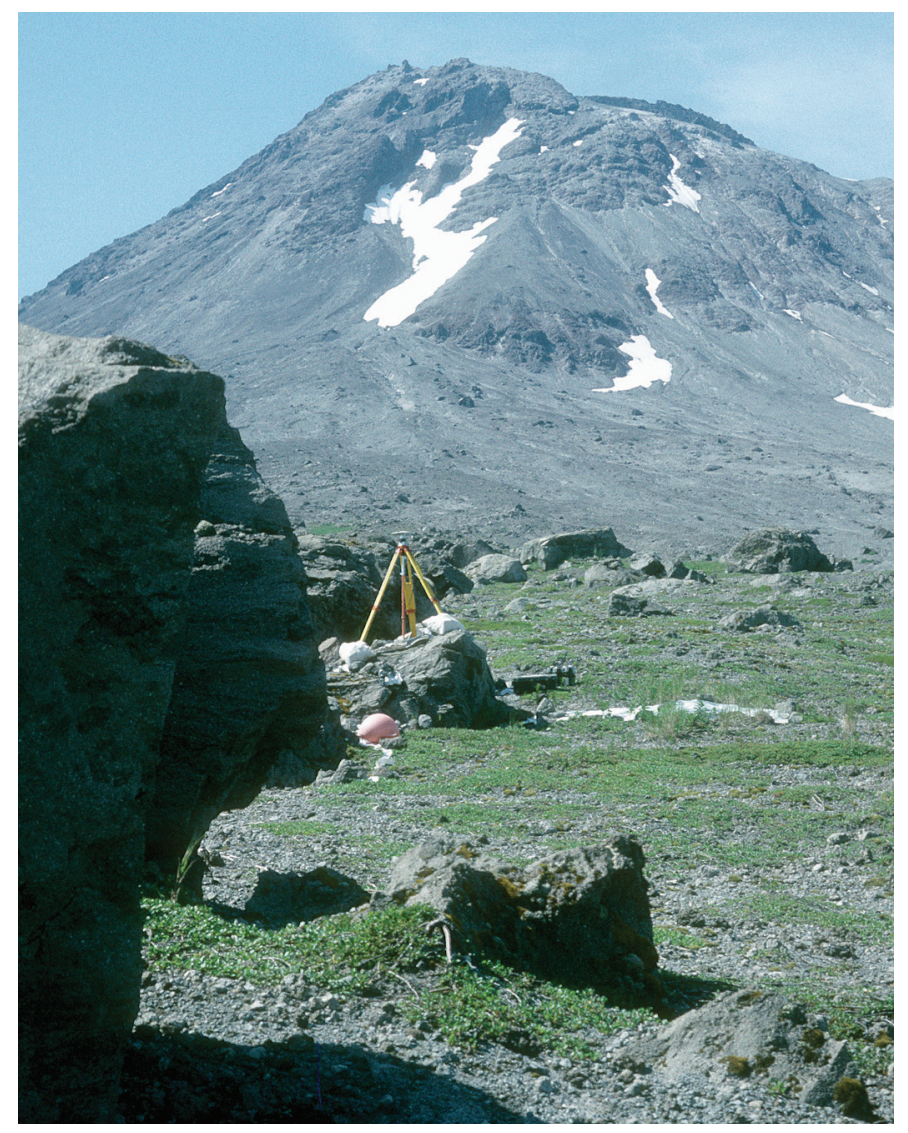

Figure 28. View northwest of boulders on southeast pyroclastic fan of Augustine Island, apparently a lithic pyroclastic-flow deposit formed from partial collapse of prehistoric hot dome (modern dome forms skyline). (USGS photograph by Richard Waitt.) 
young deposits, any old tephra that may have fallen here is buried. Only tephra B demonstrably fell this far north. In gullies upslope and back from the sea cliff, North Bench debrisavalanche deposit is discontinuously overlain by as much as $1.5 \mathrm{~m}$ of deposits including a pyroclastic-flow deposit (not distinguished on plate 1), pumiceous tephra B, three younger sand ashes, and the Katmai 1912 silt ash. This stratigraphy includes tephras older than atop the nearby West Island debrisavalanche deposits (including Grouse Point).

Yet atop North Bench near the prominent arrested sea cliff, overlying strata are oddly thin and young, only 1 or 2 sand-ashes beneath the Katmai 1912 white-silt ash. The strata here seem incomplete. This could be related to why stratigraphy of the seaward part of Lagoon avalanche deposit (described below) is incomplete: later overwash by tsunami as big West Island avalanche crashed into the sea.

\section{Deposits Between Tephras C and M (about $1,000-750{ }^{14} \mathrm{C}$ yr B.P.)}

\section{Lagoon Debris-Avalanche Deposit}

Lagoon debris-avalanche deposit (unit CMal, plate 1) is hummocky with local relief of $10 \mathrm{~m}$ and contains angular andesite boulders at least as large as $3 \mathrm{~m}$. In the highest two coastal exposures and in high places inland, it is overlain by about $60 \mathrm{~cm}$ of peat and tephra, at whose base is discontinuous pumice lapilli locally as thick as $20 \mathrm{~cm}$. A pumice deposit this thick is far more characteristic of tephra $\mathrm{M}$ than tephra B. Indeed on the highest coastal hummock, a thin discontinuous pumice (tephra B) distinctly overlies the thick pumice (tephra M). Trace-element chemistry also suggests the thick layer is tephra M (Begét, unpub. data).

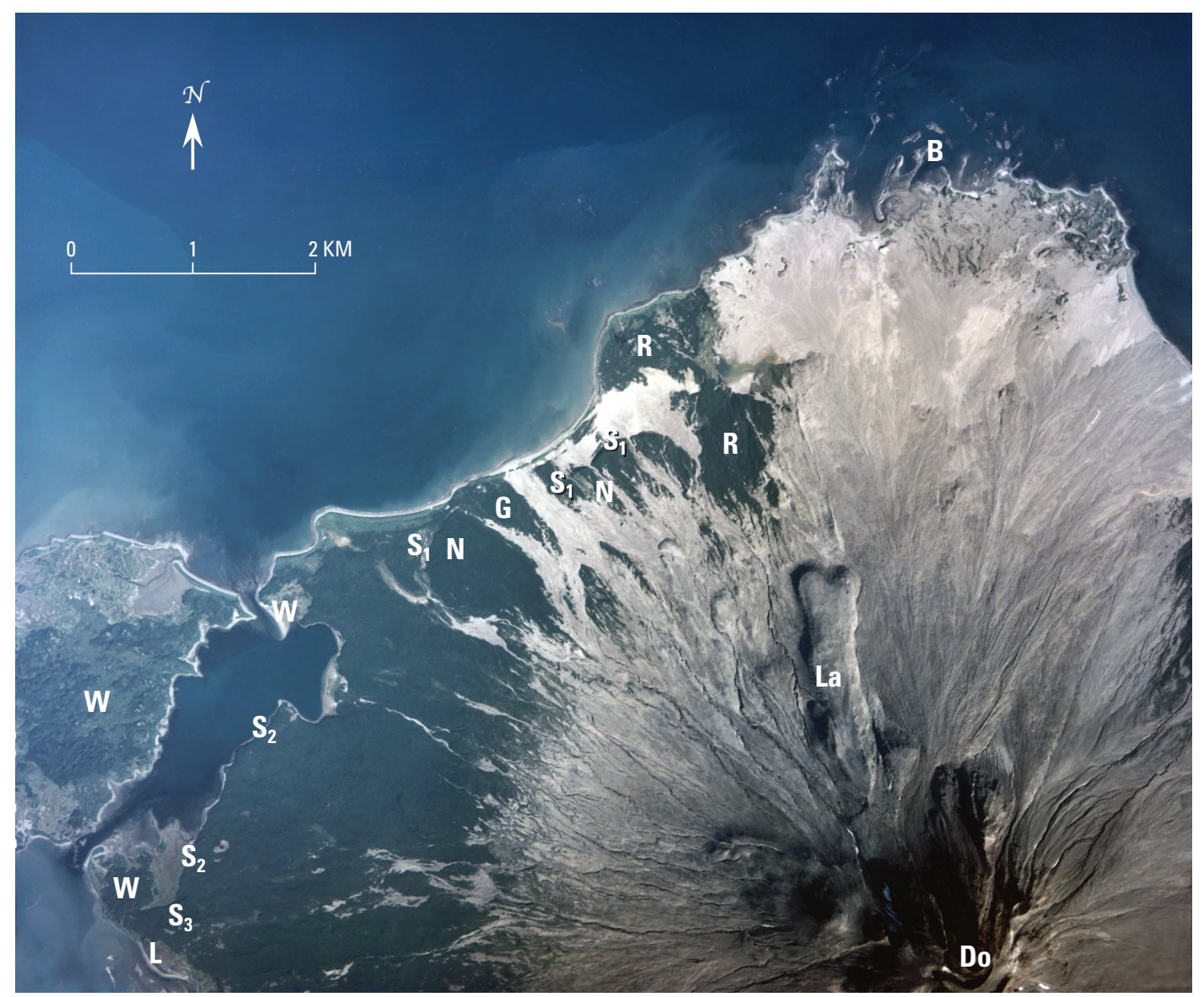

Figure 29. Vertical aerial photo of Augustine's north flank showing dome complex (Do), North Slope lava flow (La) and the debris-avalanche deposits named North Bench (N), Lagoon (L), West Island (W), Rocky Point (R), Burr Point (B), and the Grouse Point arm (G) of West Island avalanche. The arrested sea cliff cut into North Bench deposit $\left(S_{1}\right)$ may continue southwest as the scarp that bounds Northwest Lagoon $\left(S_{2}\right)$, which is then crossed by the strange scarp $\left(S_{3}\right)$ bounding Lagoon debris-avalanche deposit. (USGS photograph by Richard Waitt.) 


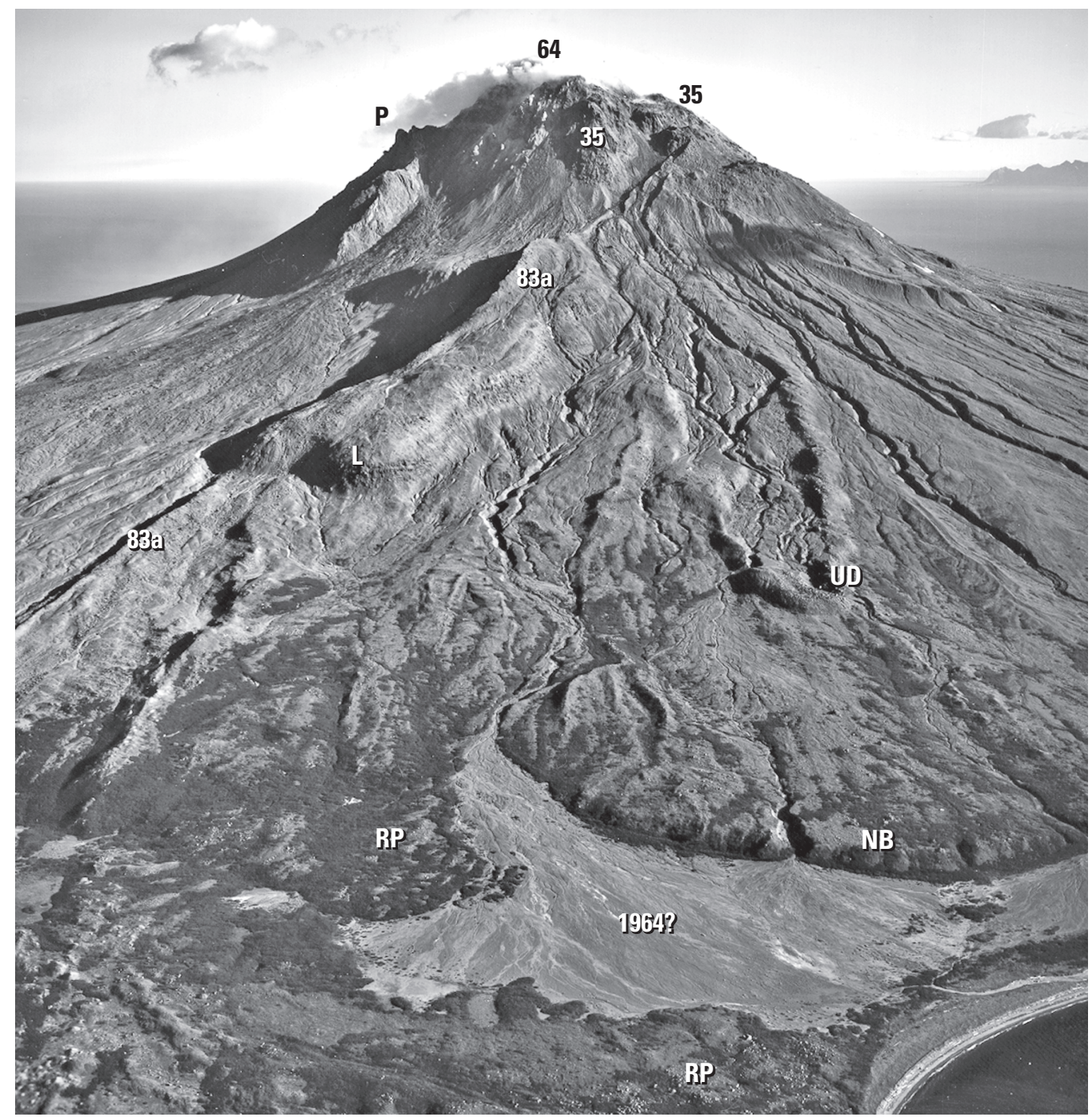

Figure 30. Oblique aerial photo toward south-southeast showing North Slope lava flow (L), arrested sea cliff cut in North Bench debris-avalanche deposit (NB), Rocky Point debris-avalanche deposit (RP), and 1883 debris-avalanche levee (83a) across and below the lava flow. Most recent domes are 1935 (35) and 1964 (64, in clouds). Pinnacles (P) is part of prehistoric summit-dome complex beheaded by 1883 landslide. Conspicuous debris-flow levees on midslope (UD) are likely historical but cannot be dated. Light-colored, fresh-looking pyroclastic flows and lahars(?) (1964?) are probably of 1964 eruption. They have since been buried by similar deposits of 1976 and 1986 eruptions. (USGS photograph by Austin Post, 3 September 1966.)

Lagoon deposit has a conspicuous left-lateral levee partly buried by a lithic pyroclastic-flow deposit (unit MBplo) to the south, which downslope at the coast is capped by tephra B and underlain by tephra M. Like Northeast Point debris-avalanche deposit, part of the hummocky Lagoon debris-avalanche deposit lies outside (south of) this levee, which suggests that the avalanche arrived in at least two closely spaced pulses.

Lagoon debris-avalanche deposit apparently buried and rode beyond a northeast-trending sea cliff cut into older deposits, perhaps a southwest continuation of the sea cliff bounding North Bench $4 \mathrm{~km}$ to the northeast. Lagoon debris-avalanche deposit projects $700 \mathrm{~m}$ seaward of this old cliff but is itself only moderately cut back and thus geomorphically is fairly young.

Yet the north side of Lagoon debris-avalanche deposit is truncated by a strange, sharp and continuous scarp (scarp $\mathrm{S}_{3}$ on fig. 29) bounded by a patch of the younger West Island debrisavalanche deposit (see below). The orientation and straightness of this scarp and the fact that landward it starts above the older wave-cut scarp, are all wrong for it to have been cut back into Lagoon debris-avalanche deposit by sea waves. Its form suggests that the huge, fast-moving West Island debris-avalanche 
remobilized and incorporated the north edge of Lagoon debris, the scarp a result of this shearing off.

Almost all of the 400-m-long coastal cliff cut into Lagoon deposit is devoid of the M and B tephras. Only the top of the highest two hummocks, above altitude $8 \mathrm{~m}$, contain the tephras. Something seems to have washed over these coastal hummocks and removed the once-present tephras (see below).

\section{Pumiceous Pyroclastic-Flow Deposit}

In a coastal gully $300 \mathrm{~m}$ west of Augustine Creek, a sandy pumiceous pyroclastic-flow deposit (unit CMp, plate 1) 0-3 $\mathrm{m}$ thick underlies tephra $\mathrm{M}($ ?) and overlies the thick, oxidized pumiceous pyroclastic-flow deposit of Southwest pyroclastic fan (unit HCpwp). This younger unit, scarcely eroded, pinches out about $0.5 \mathrm{~km}$ west of the creek: its overbank spillage was thus limited to the vicinity of the present creek.

The top of a pumiceous, faintly bedded fine sand to silt deposit (ash-cloud surge?) crops out sparsely-it is mostly covered - just beneath the M tephra along West Lagoon (unit CMp). This is perhaps a pyroclastic flow that descended a westward gully the same time as the southward flow down Augustine Creek.

\section{Lithic Pyroclastic-Flow (or Lahar?) Deposit}

A lithic small-bouldery diamict-perhaps a pyroclastic flow of lahar (unit CMI, plate 1) - as thick as $2.5 \mathrm{~m}$ poured down a broad paleoswale west of Southeast Point and lies atop the coastal bluff there. Similar flows poured across the Jurassic bedrock block and channeled down Middle and East Kamishak Creeks to overtop part of South Point debris-avalanche deposit. At the mouth of Middle Kamishak Creek the deposit is eroded back into a sea cliff that descends east from 50 to $30 \mathrm{~m}$ high with the slope of the fan surface. These easily eroded south-coast deposits must have been extensive before they were cut back into sea cliff remnants. They must be a source that longshore drift distributed into the older of the extensive beach deposits accreted to southwest corner of Augustine Island (unit bedo).

\section{Deposits Between Tephras M and B (about $750-400{ }^{14} \mathrm{C}$ yr B.P.)}

\section{Pyroclastic-Flow and Lahar Deposits}

Atop a sea cliff now isolated from the sea along the inner margin of West Lagoon is a 4-m bed of massive cobbly sand, apparently lithic pyroclastic-flow (or lahar?) deposit (unit MBplo, plate 1). It is capped by tephra $\mathrm{B}($ ?) and at one site underlain by tephra $\mathrm{M}($ ?). This deposit formerly extended at least $300 \mathrm{~m}$ seaward, its legacy a lag of numerous boulders in West Lagoon as large as $2.5 \mathrm{~m}$. Waves must have eroded the deposit back during the M-B period, and then a north-growing sand spit enclosed the lagoon and isolated the sea cliff from ocean waves.
Upslope at altitudes 40 to $90 \mathrm{~m}$ the deposit (unit MBpli) is marked by intricately lobate termini, where it is bouldery with angular clasts as large as $1.7 \mathrm{~m}$, some reddish, some gray, in a granular-sand matrix. High (proximal) parts of this deposit are marked by numerous sharp levees containing boulders as large as $3.3 \mathrm{~m}$, some of them with smaller boulders piled behind (upslope). The bouldery levees superficially resemble the occasional tall ones along the margins of some debris-avalanche deposits, but here they are much lower and are many. The levees associate with scores of separate small, delicate flow lobes, clearly a lithic pyroclastic-flow deposit. The deposit adjacent to the levees lacks a hummocky topography even though it's scarcely infilled by tephra and soil. The granular-sand matrix has developed a brown nonclayey soil and is capped by Katmai 1912 ash. This coarse inboard facies is overlapped from upslope by coarse debris shed during the later growth of dome $\mathrm{P}$.

\section{Southeast Beach Debris-Avalanche Deposit}

A bouldery diamict exposed in upper part of bluff along Southeast Beach (unit MBas, plate 1) is studded with angular blocks as large as $2.5 \mathrm{~m}$; lag boulders on the beach are as large as $6 \mathrm{~m}$, and in the surf zone are as large as $7 \mathrm{~m}$. The diamict is overlain by tephra B and underlain by tephras $\mathrm{M}$ and $\mathrm{C}$. These tephras overlie unit HCpe that forms most of bluff. Adjacent lahar or pyroclastic-flow deposits (units MBIp and MBp) are smoother and contain angular lithic andesite clasts no larger than $2 \mathrm{~m}$.

\section{Deposits Younger than Tephra B (younger than about $400{ }^{14} \mathrm{C}$ yr B.P.)}

\section{West Island Debris-Avalanche Deposit}

\section{Main Deposit}

A diamict of brecciated andesite forms West Island, separated from the northwest coast of Augustine Island by Northwest Lagoon, $1 / 2 \mathrm{~km}$ wide (figs. 29, 31, 32). (Most local

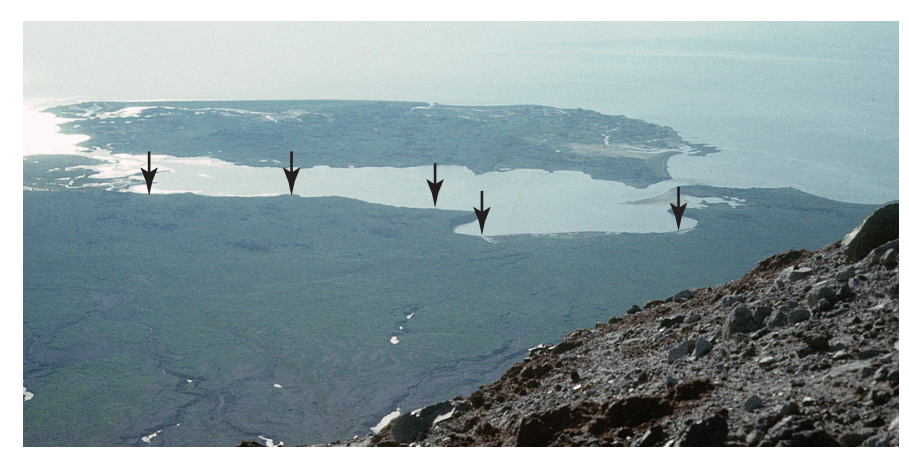

Figure 31. View west-northwest from high on cone of Augustine Volcano showing West Island, one of the largest of Augustine's debris-avalanche deposits. Arrows point to an old sea cliff the avalanche overrode. (USGS photograph by Richard Waitt.) 


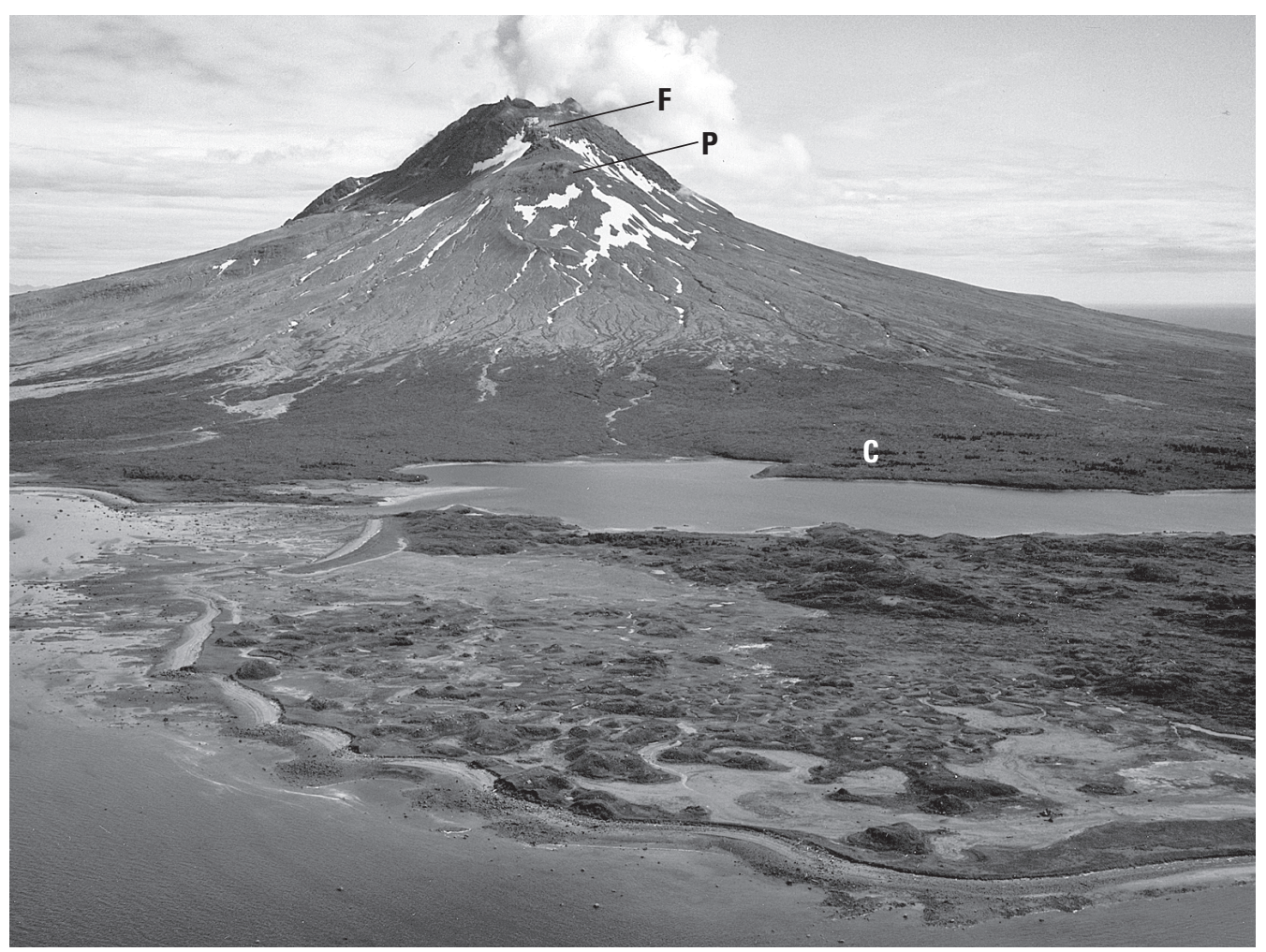

Figure 32. Oblique aerial view southwestward of Augustine Volcano and its offshore West Island. The back of Northwest Lagoon is an overridden former coastal sea cliff (C). Most of West Island debris avalanche had enough momentum to ride well beyond former shore. Two domes ( $F$ and $\mathrm{P}$ ) below summit-dome complex probably fill a former crater scar that must have been evacuated by the great West Island landslide (avalanche). (USGS photograph by Richard Waitt.)

names in this section are informal. See figure 2 and note 7.) The deposit is a mixture of angular to very angular reddish to gray porphyritic andesite boulders commonly as large as $2-3 \mathrm{~m}$, rarely to $5 \mathrm{~m}$, set in a nonsorted brown matrix of finer diamict of mixed andesite rock types (fig. 33). This matrix surrounds rare irregular convoluted pods of loose, gray, monolithologic andesite, apparently highly disaggregated single blocks.

The West Island deposit comprises a central core of unmodified conical hummocks as high as $30 \mathrm{~m}$ with slopes as steep as $40^{\circ}$ (fig. 34 ), surrounded on seaward sides by a wide zone of lower hummocks (all unit Bawo, plate 1). A patch of this hummocky deposit also lies south of the lagoon, lodged against the older Lagoon debris-avalanche deposit (unit CMal), whose north side seems sheared by the West Island avalanche and incorporated into its deposit there (see above). A second hummocky patch lies east of the lagoon, southeast of West Island. Indeed the hummocky topography of the mainland parts of unit Bawo is indistinguishable from that on West Island. Much of the area is thickly furred by alder and scrub spruce, far more than any historical deposit.

On the seaward (north) side of West Island a discontinuous sea cliff cut into sporadic hummocks (fig. 33) is fairly straight. A continuous field of boulders ranging up to $5 \mathrm{~m}$ in diameter extends at least as far as $1 \frac{1 / 3}{3} \mathrm{~km}$ offshore (unit ob,

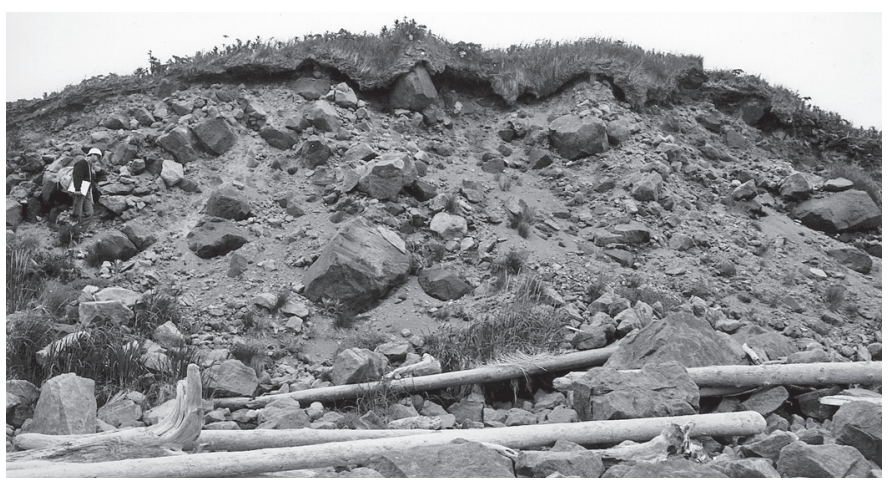

Figure 33. Coastal sea cliff exposing interior of debris-avalanche hummock on West Island, just off Augustine Island, Alaska. For scale note person on the left. (USGS photograph by Richard Waitt.)

plate 1), much of it visible at lowest spring tides and discernible on aerial photographs. Hummocky topography extends $2^{1 / 2} \mathrm{~km}$ offshore (fig. 11) $-5 \mathrm{~km}$ beyond the sea cliff.

The hummocks and intervening lows are overlain by 0 to $30 \mathrm{~cm}$ of humic soil and peat interrupted by five sand ashes of which three underlie the Katmai 1912 ash (fig. 35). Coarse tephra B is absent from West Island, and thus the hummocky 


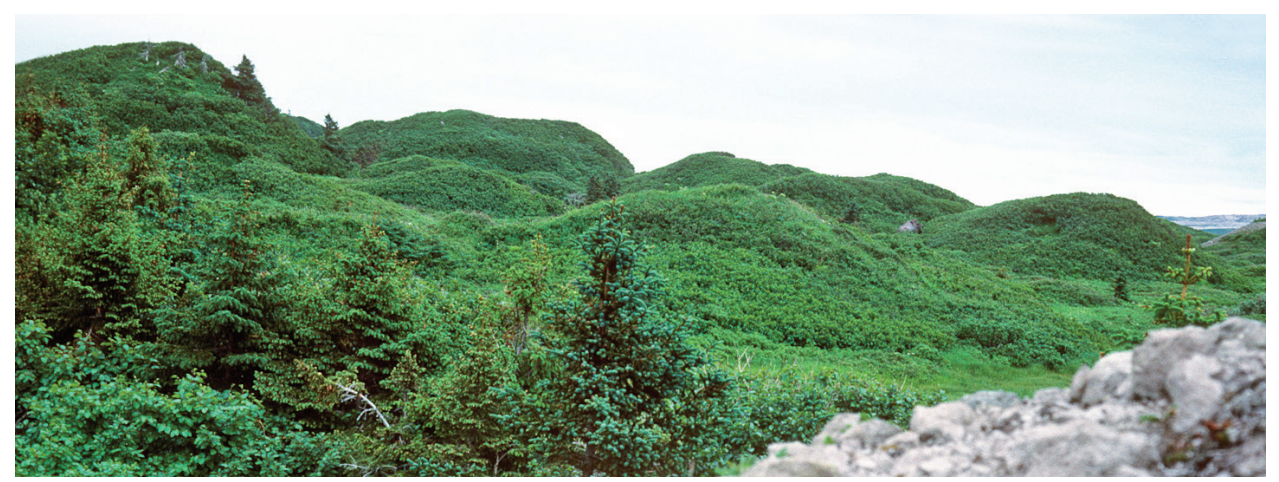

Figure 34. View southeastward of southwest side of central core of high conical hummocks of West Island debris-avalanche deposit. Compare with Burr Point hummocks (fig. 43B). (USGS photograph by Richard Waitt.)

diamict is younger than about $390 \mathrm{yr}$ B.P. (table 2). A radiocarbon age from alder bark at about 370 yr B.P. (table 2) probably closely dates the avalanche (Siebert and others, 1995, p. 383).

A broad part of the lower northwest volcano flank upslope of Northwest Lagoon is veneered by the coarse West Island debris-avalanche deposit (unit Bawi), a nonsorted angular coarse rubble containing angular boulders as large as 4 meters. This inland facies is distinguished by a separate map symbol (plate 1) only because it veneers older topography rather than being a thick new deposit. The area of the inland facies is mostly covered by dense scrub spruce. In a gully $1.2 \mathrm{~km}$ back from the lagoon at altitude $85 \mathrm{~m}$, the deposit is underlain by $35 \mathrm{~cm}$ of tephra M (or B?). Lower in same gully a meager soil developed on the diamict is capped only by $1883(?)$ pyroclasticflow deposit and by several layers of sand-sized fall ash.

This inland rubble overlies similar but ambiguously exposed bouldery rubble of an older deposit (a west arm of North Bench avalanche? or east part of Lagoon avalanche?). Into this older diamict a sea cliff had been cut 8 to $18 \mathrm{~m}$ high. It demarked the northwest coast of Augustine Island just before the West Island avalanche and now forms the southeast coast of Northwest lagoon. The overriding West Island avalanche fluted the surface of this deposit, especially the sea cliff. This erosional fluting normal to the coastwise cliff, and the veneer of unit Bawi, smooths the cliff face to a slope $30^{\circ}$ and less. And the cliff's top is broadly upwardly convex in place of the usual sharp angle. Most of West Island avalanche swept more than half a kilometer beyond this old cliff, a gap behind now occupied by Northwest Lagoon.

At several sites the tough diamict is immediately overlain by a much looser poorly sorted gravelly sand typically 10 to $30 \mathrm{~cm}$ thick containing angular clasts of juvenile-looking andesite (fig. 35). Siebert and others (1989) interpret this material deposit as the residue of a Mount-St.-Helens-type lithic pyroclastic-surge (some call it "blast") $)^{8}$ deposit (for example, Waitt, 1981) — which the Augustine deposit indeed resembles. It is widely but sporadically distributed — on both sides of Northwest Lagoon but only rarely on hummocks on the west and north of

\footnotetext{
${ }^{8}$ Term "blast" is much misunderstood at Mount St. Helens and could be here. "Blast" is in sense of a fierce blast of wind, not an explosion. Thus in the Oxford English Dictionary (1971 edition) definition 1, not definition 8 (explosion).
}

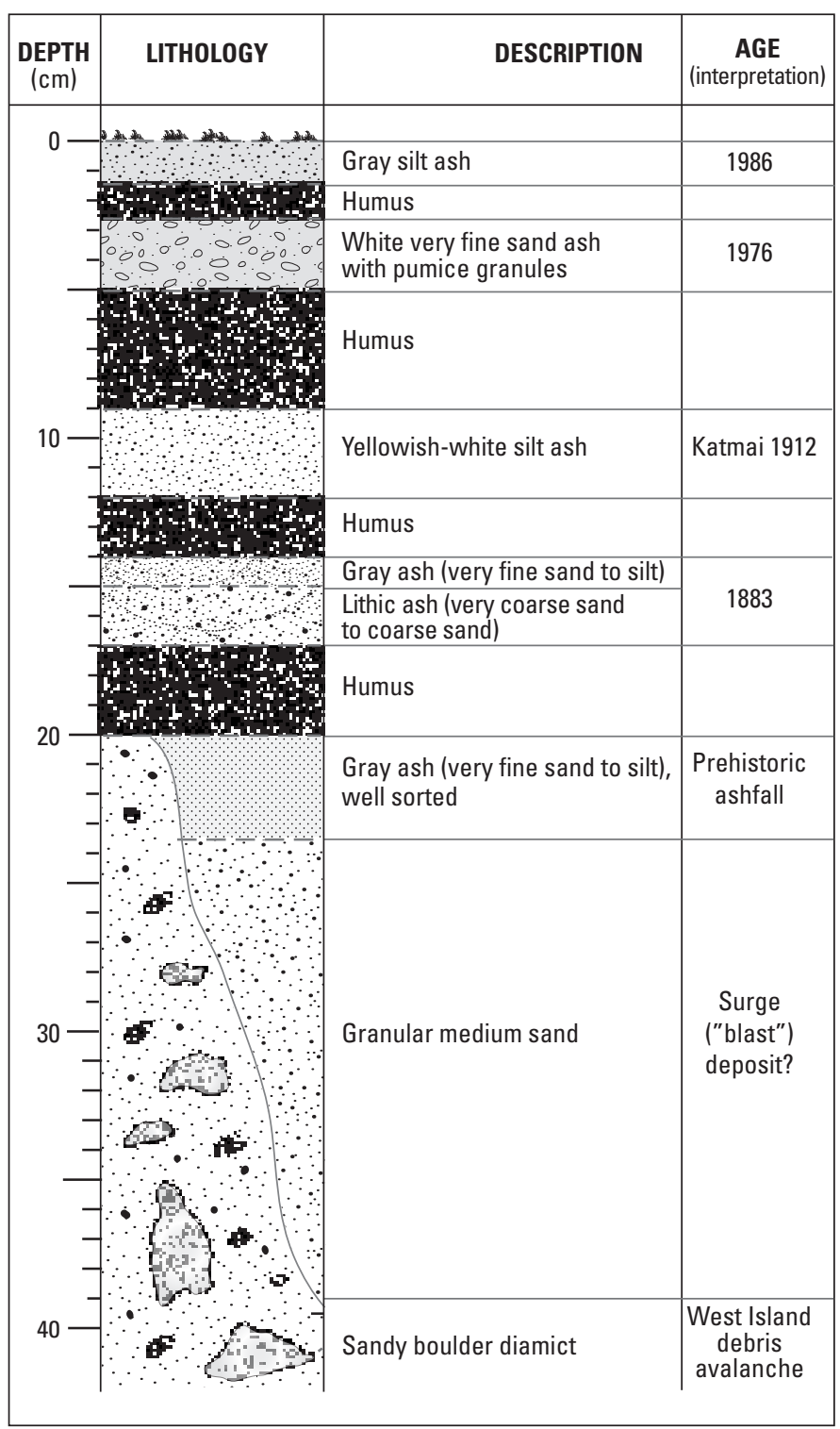

Figure 35. Stratigraphic section (at field station RBW 88A.110) showing succession atop debris-avalanche hummock on southwest coast of West Island, an area of strangely flat-topped hummocks, evidently eroded by tsunami. 
West Island. This deposit suggests that the large West Island landslide(s) unleashed a series of summit explosions - as did the Mount St. Helens landslides on 18 May 1980 - that swept over the new avalanche as a pyroclastic surge.

\section{Grouse Point Tongue}

A diamict about Grouse Point (unit Bag, plate 1) needs discussion because of earlier interpretations. The deposit is hummocky with local relief as high as $7 \mathrm{~m}$ and is composed of gray to reddish porphyritic andesite whose angular boulders are at least as large as $2.5 \mathrm{~m}$. One hummock 9 by $15 \mathrm{~m}$ in plan seems to consist largely of a single highly shattered andesite block. On the beach just seaward, wave-winnowed boulders reach $7 \mathrm{~m}$. Clearly this is a debris-avalanche deposit. Overlying deposits in upward stratigraphic succession are pyroclastic-flow or waterlaid sand, two or three ash layers, and the distinctive white Katmai 1912 ash —not unlike stratigraphy overlying the outboard main phase (unit Bawo) of West Island.

At lowest tides a field of boulders extends nearly a kilometer seaward of the present beach, and bathymetric contours suggest it extends another $0.5 \mathrm{~km}$ offshore. This is the area of Peter Puget's boulder-obstructed landing in 1794 (see below). The deposit has been eroded back into a nearly continuous, sharply curving sea cliff 4 to $7 \mathrm{~m}$ high. This geomorphic character is similar to that of the coarse and hummocky West Island deposit but much less eroded back. Thus it is much younger than the South Point and other debris-avalanche deposits on the south and east coasts.

Grouse Point deposit crosses part of the sea cliff cut into North Bench debris-avalanche deposit (figs. 29, 36). By this and its far more hummocky surface texture, Grouse Point deposit is geomorphically distinct from North Bench deposit. Also contrasting the arrested high sea cliff bounding North Bench, Grouse Point is low and juts into the sea. Grouse Point deposit thus considerably postdates the North Bench deposit.

Tephra B does not overlie the Grouse Point deposit, but it is exposed in several gullies upslope from North Bench diamict (unit IMan) (fig. 29). Earlier reports (Begét and Kienle, 1992; Siebert and others, 1995) lumped the west part of North Bench deposit and the Grouse Point deposit together. Because of the tephra in the upslope gullies, they inferred (incorrectly) that Grouse Point deposit predates tephra B.

The Grouse Point rubble flowed to the coast down a swale east of a broadly whalebacked west part of North Bench deposit (figs. 29, 36); a similar flow descended a gully west of the whaleback. This western deposit is continuous with the West Island debris-avalanche deposit (plate 1). These deposits about Grouse Point seem to be a thin east edge of West Island debris avalanche. Descending the cone, this east edge struck the upslope end of the North Bench whaleback, bifurcated, and flowed down the swales on both sides.

\section{Beveled West Island Hummocks}

Hummocks on the southwest side of West Island are oddly flat topped, apparently beveled down as much as $10 \mathrm{~m}$ and more (fig. 37) and are steeply incised by a network of steep-sided channels etched along adjacent lows. Some of the hummocks are capped by a coarse winnowed lag of openwork boulders as large as $4 \mathrm{~m}$ (fig. 38). Separating some some of these boulders are gaping voids as deep as $1.5 \mathrm{~m}$. These modified hummocks are evidence of a great rush of water over them-probably as West Island debris avalanche plowed at high momentum into the sea. And so here is field evidence of of a great sea wave (tsunami) being initiated by the speeding avalanche. An 1883 tsunami originating from Burr Point could not have caused the modification, for the low-level hummocky north part of West Island closer to and facing Burr Point is not also modified. And at least one of the modified hummocks is overlain by three layers of sand ash beneath the 1912 Katmai ash as on northern West Island and on Grouse Point (fig. 35). Therefore the wave modification occurred about the time of emplacement of West Island, not much later.

The two coauthors favor different origins of the hydraulic planing. Waitt thinks its cause was the initially stationary sea

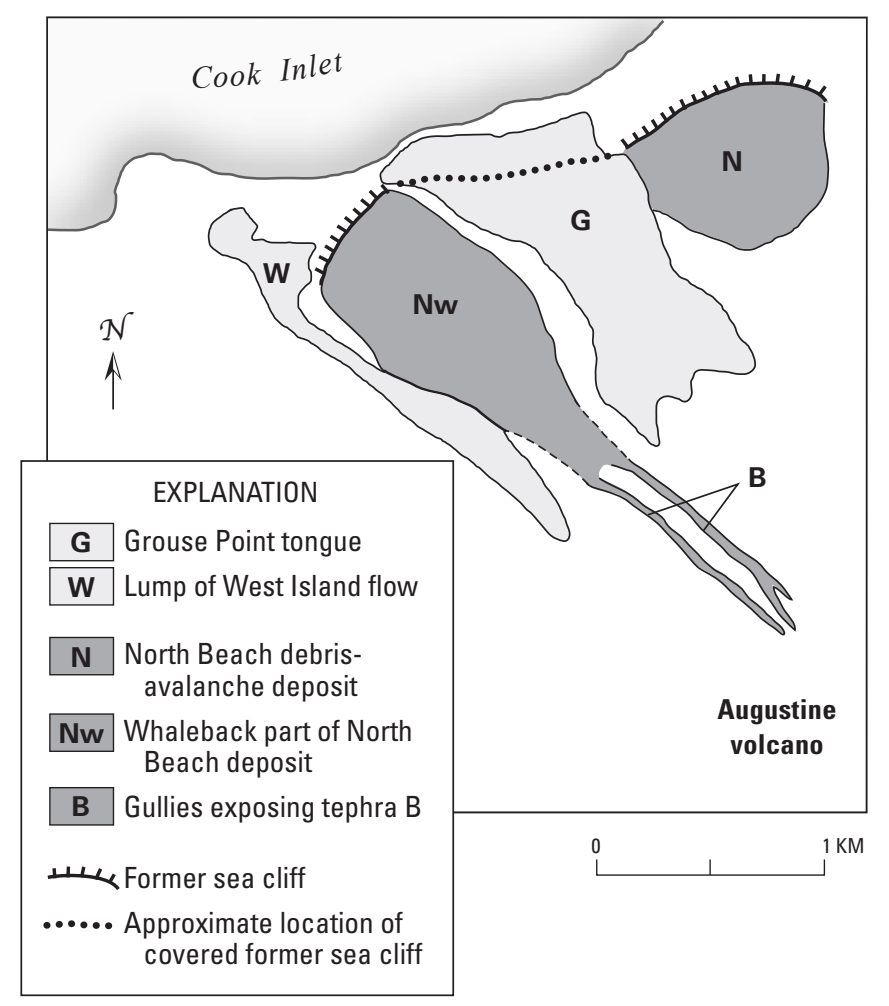

Figure 36. Sketch map showing details of Grouse Point area, Augustine Island. N, North Bench debris-avalanche deposit cut back into sea cliff, since arrested; Nw, western whaleback part of North Bench deposit that divided later West Island flow: G, Grouse Point tongue down east swale; and W, lump of West Island flow down west swale (both of them apparently sweeping beyond sea cliff cut into headlands). $B$, gullies just upslope from whaleback exposing tephra B, thus minimum-limiting age for the North Bench diamict but not for the Grouse Point tongue. White area, Augustine deposits mostly younger than the units specially depicted (see plate 1). 

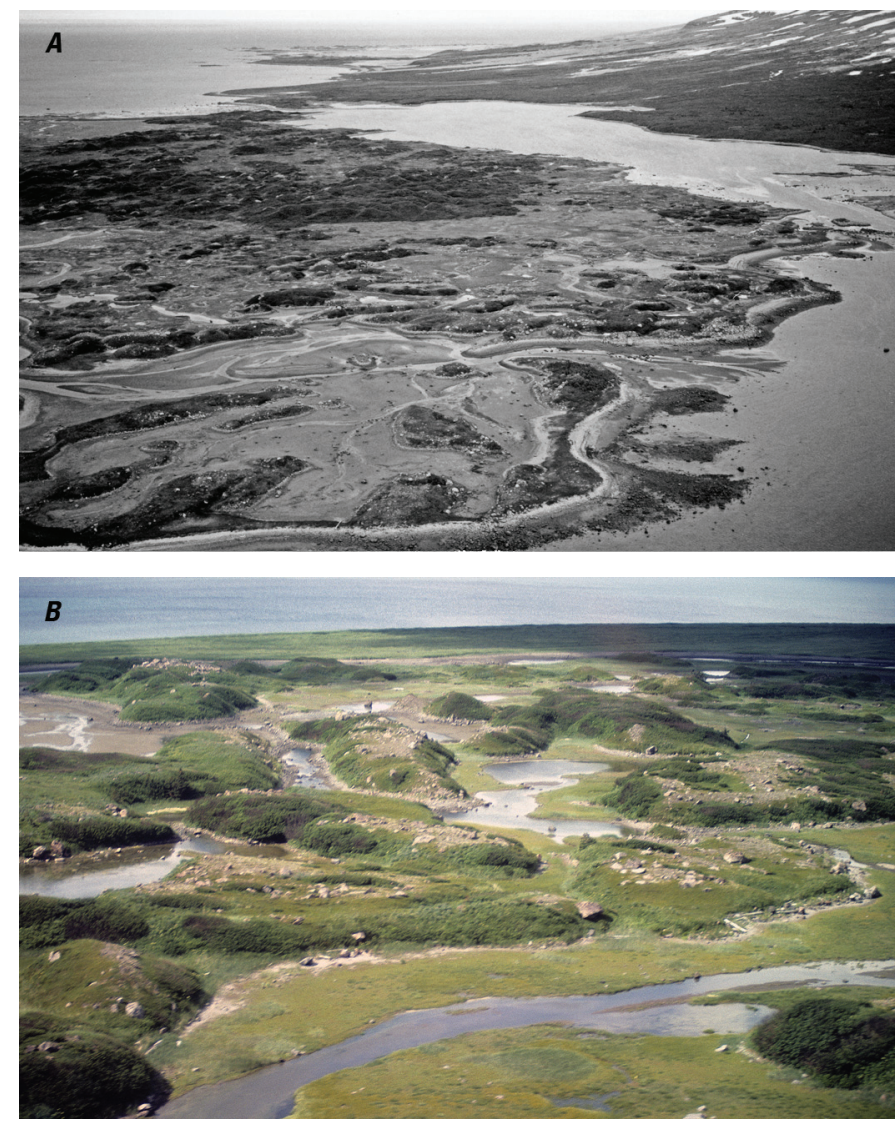

Figure 37. Oblique aerial photos of oddly planed-off hummocks on southwest part of West Island, at Augustine Island, Alaska. The modified hummocks and scabland-like channels between them are inferred to be erosional beveling by tsunami across this part of the West Island debris-avalanche deposit. $A$, Distant view east. $B$, Near view north. (USGS photographs by Richard Waitt.)

riding back over the top of the swift-flowing debris avalanche as it plowed into the sea. This act suddenly displaced water, generating the initial tsunami wave, most of the displacement having been by the huge undersea portion of the deposit (unit ob offshore of West Island, plate 1). Begét thinks that two debris avalanches may compose West Island, the second avalanche represented by the central core of high steep hummocks. Thus a less-extensive second catastrophic displacement of seawater washed over and planed off hummocks of the first. Both hypotheses imply violent displacement of seawater - and initiation of a tsunami.

A few of the beveled hummocks 4 to $5 \mathrm{~m}$ above high-tide level retain a capping of poorly sorted pebbly sand 5 to $25 \mathrm{~cm}$ thick, apparently a distal phase of a lithic pyroclastic-surge ("blast") facies 9 (see above). This deposit implies that any

\footnotetext{
${ }^{9}$ By its stratigraphic position directly atop the apparently wave-beveled eroded hummocks, we contemplated this as a tsunami deposit. But all its gravel clasts are angular andesite, and two samples submitted for diatom analysis revealed not one marine diatom (Eileen Hemphill-Haley, written commun., 1995). We discarded the tsunami-deposit idea.
}

catastrophic washing of the underlying surface by sea wave was brief - the surface soon again became subaerial to receive the surge deposit. A weak brown soil in the pebbly sand is $8 \mathrm{~cm}$ thick, atop which lie two or three sand ashes beneath the distinctive white-silt Katmai 1912 ash.

\section{Modified Hummocks of Lagoon Avalanche (and North Bench Avalanche?)}

Tephras M and B clearly overlie Lagoon avalanche back from the coast and also the highest two hummocks (above $8 \mathrm{~m}$ ) at the coast. But just south of West Island avalanche, most of the nearly continuous 420-m-long coast exposure of Lagoon avalanche that lies below altitude $8 \mathrm{~m}$ is devoid of the $\mathrm{M}$ and $\mathrm{B}$ tephras. This absence over so large an area is striking. Parts of these low coastal parts of Lagoon debrisavalanche deposit are also strangely capped by many large boulders, as if a coarse lag from an episode of erosion. These low parts of Lagoon avalanche thus resemble in some ways the beveled hummocks on the southwest coast of West Island but are far less modified. They too seem to have been swept over by some great wash of water at about the time the nearby southwestern West Island hummocks were modified. From this evidence at Lagoon avalanche - independent of relations on West Island - we infer that as the West Island debris avalanche plowed into the sea, it raised a great wave of water. Briefly it swept energetically up onto the older Lagoon deposit to at least 8 meters above tide.

This same wave may have washed over North Bench to the east, and thus explain the seemingly truncated overlying stratigraphy for a deposit old geomorphically by its straight sea cliff evidently eroded far back.

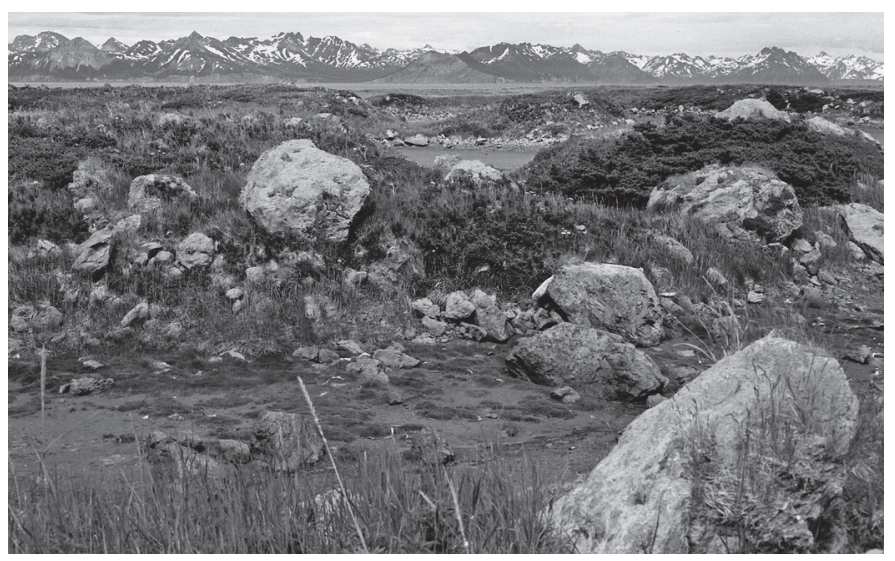

Figure 38. View northeast of southwestmost part of Augustine's West Island showing oddly flattened hummocks cut by scablandlike channels and surficial matrix-free lag of large boulders. View is from one flattened hummock across to others. On horizon are Chigmit Mountains of the Alaska (or Aleutian) Range exposing mostly Mesozoic sedimentary, volcanic, and plutonic rocks. (USGS photograph by Richard Waitt.) 


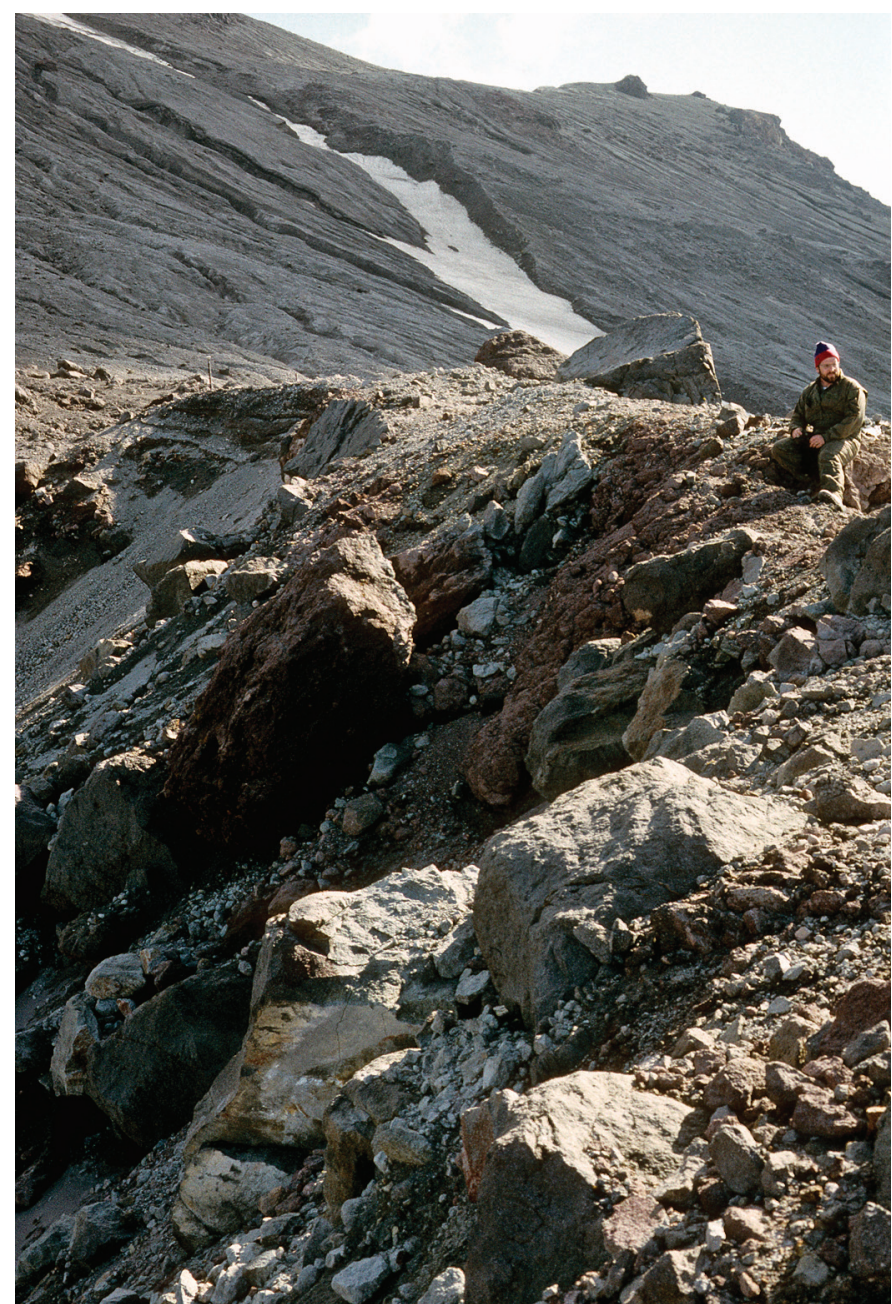

Figure 39. Photo showing Bouldery diamict of debris-avalanche levee, a deposit of mixed andesite rock types, resting atop North Slope lava flow, north flank of Augustine Volcano. (USGS photograph by Richard Waitt.)

\section{Rocky Point Debris-Avalanche Deposit}

East of Grouse Point and west of Burr Point, a coarse diamict (unit Bar, plate 1) forms a broad point of land, Rocky Point (figs. 29, 30). The deposit contains angular andesite boulders at least as large as $5 \mathrm{~m}$. Its sharply hummocky topography has relief of 5-15 $\mathrm{m}$ and slopes as steep as $35^{\circ}$. At low tide this debris also forms bouldery islands and shoals (unit ob) as far as $1.5 \mathrm{~km}$ offshore that waves have winnowed and beveled. The Rocky Point deposit is about 80 percent covered by scrub alder but lacks the spruce covering parts of West Island and Lagoon debris-avalanche deposits and thus seems younger than West Island. Upslope from the main deposit about Rocky Point are vegetated debris levees as high as $15 \mathrm{~m}$ that apparently define the two sides of this debris avalanche.

Capping the coarse diamict in upward succession is weakly oxidized soil $20 \mathrm{~cm}$ thick, an organic layer, a graysilt ash (1883 eruption?), and the white-silt ash from the
1912 Katmai eruption. The sharp morphology of the hummocks and the irregular, curving sea cliff line are similar to that at West Island. But a single sand-ash layer beneath the Katmai ash makes this deposit considerably younger than the West Island debris-avalanche yet the soil and peat atop the avalanche show it to be distinctly older than the Burr Point avalanche (see below).

Hummocks on the east side of the Rocky Point diamict are coated by ash-cloud deposits of 1976 and 1986 eruptions. Airphotos of July 1957 show parts of the deposit also scorched and mantled by ash clouds that swept beyond 1883 pyroclastic flows. Because these east-side alder thickets having been burned off repeatedly, the hummocks appear as if unvegetated youth like the adjacent Burr Point hummocks. This blurred vegetative distinction between the Rocky Point and Burr Point deposits in the 1980s and early 1990s had been somewhat repaired by 2002 - by when the alder thicket on the eastmost Rocky Point deposit had partly regrown.

The coarse boulders and shoals jut 600 to $1,500 \mathrm{~m}$ seaward from both the Rocky Point and Burr Point deposits. We draw the boundary between the Rocky Point and Burr Point avalanches at a sharp reentrant in this offshore bouldery debris, where instead lies only sand. Within this reentrant the offshore debris is much finer, lacks boulders, and even at lowest spring tide is exposed no more than $200 \mathrm{~m}$ offshore (unit os, plate 1).

Before the October 1883 landslide that formed the present-day rocky, island-studded Burr Point, there had been a small harbor on the north flank used by seafaring natives in their kayaklike "baidarkas." Capt. Cullie of the Alaska Commercial Company called it the "rocky" boat harbor. Dall (1918) wrote: "Formerly there was a boat harbor where the Aleut otter-hunters left their kayaks while they watched for their prey from the cliffs, but . . years [before our 1895] visit ... part of the wall of the crater filled the harbor with fragments of lava and masses of ashes." The pre-1883 coastal cliffs on the north-northeast and north were fairly straight but bowed inland in the form of a bay (plate 1) suggesting erodedback soft deposits such as pyroclastic flows. The "rocky" area with seaward arms protecting a harbor probably was the east edge of the Rocky Point debris-avalanche deposit, perhaps in the vicinity of the recent shallow pond (plate 1). This pond that existed at least since the 1976 eruption was in late January 2006 filled by the one large flow during that eruption (see below).

\section{Unassigned Debris-Avalanche Deposits}

Several small-volume (less than $0.1 \mathrm{~km}^{3}$ ) lobes of coarse diamict (unit Bau, plate 1) containing boulders commonly as large as $6 \mathrm{~m}$, rarely to $15 \mathrm{~m}$, lie on the north flank between altitudes 100 and $800 \mathrm{~m}$ and between the azimuths of Rocky Point and West Island debris-avalanche deposits. They have the pristine geomorphic form and lithologic character of debris-avalanche deposits but were small and did not reach the coast (fig. 30). They lack distinctive overlying stratigraphy but 
are geomorphically unmodified, clearly younger than deposits like North Bench and Lagoon debris-avalanche deposits. They may be small, late arms of the Rocky Point and West Island deposits, or they may be younger.

\section{North Slope Lava Flow}

A lava flow forming a prominent broad spur on the middle north flank of Augustine Island (figs. 29, 30) consists of massive porphyritic andesite (unit BIn, plate 1). The apex of the landform at altitude $650 \mathrm{~m}$ apparently marks the flank vent $600 \mathrm{~m}$ below the present summit — indeed below the base of the entire summit-dome complex. The lava flow terminates $450 \mathrm{~m}$ lower at a distance of $1.75 \mathrm{~km}$. The lava flow is usually considered the last part of the 1883 eruption (Kienle and Forbes, 1976; Siebert and others, 1987, 1989, 1995; Swanson and Kienle, 1988). Kienle and Swanson (1980) had called it prehistoric but gave no evidence.

Overlying the upper east side of the lava flow is a sharpcrested ridge at least $640 \mathrm{~m}$ long and as thick as $15 \mathrm{~m}$ consisting of diamict including many angular fragments as large as $6 \mathrm{~m}$ of dome-rock porphyritic andesite (fig. 39). In any one small area of this deposit the andesite boulders are diversely black, reddish, and gray, and they are of varying degrees of vesicularity. This clearly mixed deposit is a debris-avalanche levee, which can be traced downslope to altitude $450 \mathrm{~m}$ and discontinuously below that. It aligns with a sharp levee well defined below altitude $200 \mathrm{~m}$, the west edge of the Burr Point debris-avalanche deposit (see below). Thus the 1883 debrisavalanche deposit overlies the lava flow and clearly postdates it.

The Burr Point debris avalanche occurred at or near the beginning of the 1883 eruption, and so the lava flow is of a pre-1883 eruption. The lava flow apparently is overlain by just one coarse diamict and so must postdate the Rocky Point debris avalanche, which would have swept over the lava flow had it then existed. The lava flow seems to show on Augustine Volcano's north flank in Doroshin's 1870 sketch (fig. 40A) though Siebert and others $(1989,1995)$ claim it doesn't show. Its azimuth aligned with Rocky Point and its stratigraphic level beneath the Burr Point diamict together suggest that the lava flow occurred late during an eruption that began with the Rocky Point debris avalanche.

\section{Beach and Eolian Deposits}

An area of about $1.5 \mathrm{~km}^{2}$ lying 3 to $7 \mathrm{~m}$ above sea level on the southwest corner of Augustine Island comprises dozens of subparallel ridges, a succession of accreted beach and overlying eolian deposits (fig. 3, plate 1). The shape of spits - even the innermost (oldest) curl landward - tell that longshore currents have for more than a millennium been clockwise around the south and west of Augustine Island. From geomorphic position alone the landward ridges are much older than seaward ones, and to reflect this we divide the whole sequence into older, intermediate and younger phases (units bedo, bedi, bedy, plate 1) separated only by indefinite (wash) contacts. Small wave-cut cliffs into this deposit along the south coast and along West Lagoon and several pits dug into it show that the ridges are mostly of well-sorted medium sand, apparently eolian.

Pits dug into the landward half of these ridges (unit bedo and part of unit bedi) show tephra $\mathrm{M}$ to be $30 \mathrm{~cm}$ and more thick (plate 2, section RBW 92A.26). These landward ridges thus predate $750 \mathrm{yr}$ B.P.; they are mantled by 25 to $70 \mathrm{~cm}$ and more of younger eolian sand containing reworked tephra $\mathrm{M}$. The cut in West Lagoon (exposing unit bedi) shows that overlying tephra M is 3 m of eolian sand capped by Katmai 1912 ash. The landmost ridges (unit bedo) may well contain tephra $\mathrm{C}$ beneath tephra $\mathrm{M}$, but when examined even in late summer the deposit has been frozen - unexcavatable - below $70 \mathrm{~cm}$.

On the southwestern beach-ridge deposit, the sand ridges seaward of a small north-draining estuary seem devoid of tephra $\mathrm{M}$ and thus accreted since about $750 \mathrm{yr}$ B.P (unit bedy). All but several of the most seaward of these eolian ridges enclose one or more sand ashes beneath the Katmai 1912 ash and thus are prehistoric in age.

The seaward two ridges (west part of unit bedy) have less than $40 \mathrm{~cm}$ of eolian sand overlying beach deposit of coarse sand to pebble gravel. Probably all the ridges originated as pebbly-sand beach strand. With time they become more and more mantled by eolian sand.

This sandy platform probably reflects a sudden delivery of voluminus sand-sized material to the south coast. By far the largest such additions from the volcano were "Southwest pyroclastic fan" and "Southeast pyroclastic fan" (units HCpwp and HCpe) - both emplaced between 1,400 and 1,000 years ago (in uncalibrated radiocarbon time). The pumiceous pyroclastic-flow deposit exposed as thick as 16 meters along the beach cliff west of Augustine Creek (unit HCpwp) is fairly loose and easily attacked by coastal surf, and it must have at first extended more than a hundred meters into the sea. It was an abundant and easy source of sand. Similar pyroclastic-flow deposits at Southeast fan (unit HCpe) would have been a ready source too, but smaller. Another loose pumiceous flow swept into the sea at Augustine Creek (unit CMp) later, between about 1,000 and 750 years ago. All together, these loose flows gave the south coast-especially south-southwest - a large source of sand far more erodible than the coarse and rocky South Point and Long Beach debris-avalanche deposits (units $\mathrm{HCas}$ and $\mathrm{HCal}$ ). No new large and loose deposit accumulated on the south coast after the $\mathrm{M}$ tephra fell (about $750 \mathrm{yr}$ B.P.) And so the abundant older deposits still being eroded back by storm waves must be the main sand source for the whole beach platform on the southwest of the island.

\section{Historical Deposits}

By "historical" we mean the period since journalkeeping European explorers seeking a Northwest Passage and 

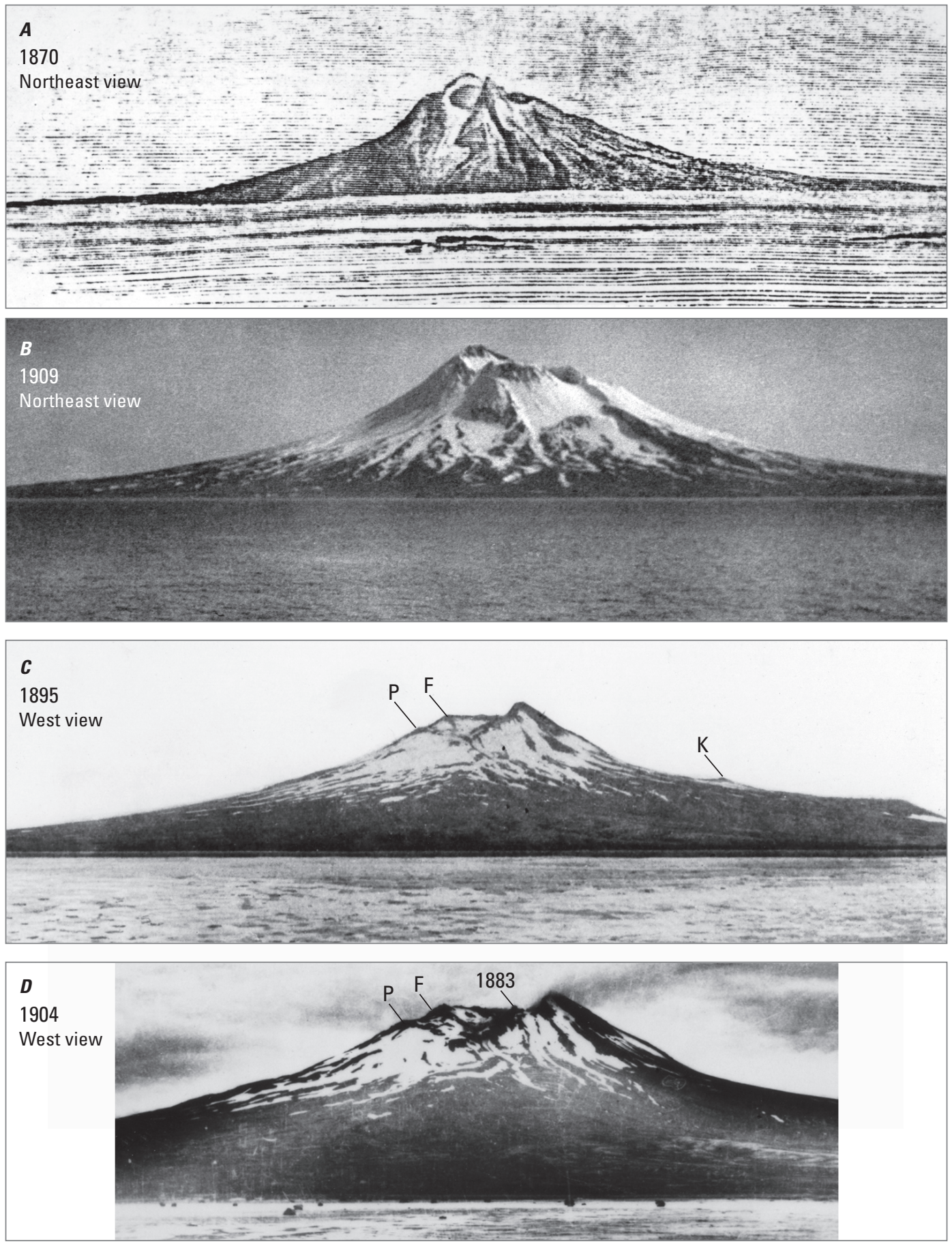

Figure 40. Augustine Volcano, Alaska, showing large-scale effects to summit area by 1883 eruption. $A$, Sketch by Doroshin (1870) showing spine, view from northeast. Bump on right horizon seems to be North Slope lava flow (unit BIn, plate 1). Compared to later photographs, the northeast shoreline of Augustine shown here is less extended: Burr Point deposit does not yet exist. $B$, Photograph taken 1909 from the northeast by John Thwaites. Since 1870 the former spine and part of upper north flank disappeared, replaced by a large lava dome. View like Doroshin's from northeast (BIn, North Slope lava flow). Compared to Doroshin's sketch, the Burr Point deposit now exists. C, Photograph taken July 1895 by C.W. Purington from a few miles west of Augustine shows crater scar left by 1883 landslide (debris avalanche) (see Becker, 1898, p. 28-30 and plate X). Subsequent 1883 dome is small, wholly within crater and below crater rim. F, dome F; P, dome P; K, dome K (Kamishak). D, Photograph taken from west in 1904 by T.W. Stanton from just inside West Lagoon. Domes: P, F, 1883. Spine of 1883 dome barely visible. 
competing for land and fur and trading rights began visiting Alaska in 1741 - the beginning of written records. First came Vitus Bering's 1741-42 voyage, then other Russian explorers such as Grigori Shelikhov entered Cook Inlet by 1785. The first such English-language report of Augustine Island was by Capt. James Cook on 26 May 1778, who penned: "This Mountain is of a conical figure and of a very considerable height" (Beaglehole, 1967). An English voyage under Capt. Nathaniel Porlock and Capt. George Dixon (both had sailed with Cook in 1778) explored Cook Inlet between 19 July and 13 August 1786 and found "smoke" issuing mildly from Iliamna (Beresford, 1968 [1789]). French ships came later in 1786, Spanish in 1792. George Vancouver (also with Cook in 1778) explored between 14 April and 12 May 1794 (Lamb, 1984) and found "whitish smoke" (steam) issuing from Iliamna. In Vancouver's lesser ship, Peter Puget sailed around Augustine's south and west on 1 May ("a lofty, uniform, conical mountain ... the same from every point of view") and next day in the launch threaded past hundreds of huge offshore rocks to the north-northwest coast. There were many other coastal-Alaska explorations besides these though few of them pertinent to Cook Inlet (see, for example, Cook and Norris, 1998, chap. 3). These various reports are very brief, each covering a few days to a couple weeks during which Augustine neither erupted nor otherwise evinced recent activity. Iliamna is the only lofty peak any of the early explorers call "volcano."

In the 1790s to 1860 s, traders such as Aleksandr Baranov tended a few small and intermittent fur-trapping and trading posts in Cook inlet. In 1849 Mikhail Teben'kov initiated a map of Cook Inlet and coastal provinces eastward. Russians probed the coasts and Cook Inlet for gold and coal in the 1850s and 1860s. After Russia sold Alaska to the United States in 1867, George Davidson (fig. 41A) began coastal mapping for the U.S. Coast and Geodetic Survey (USCGS). Since then explorations and settlement grew gradually more continuous. In all these early historical reports, the only reported Augustine eruption was 1812 .

\section{Eruption}

An obscure report by Russian geologist and mining engineer Petr Doroshin (1870) says that Chernobory (Augustine Volcano) "burned" in 1812, and native villagers from across the water couldn't reach the island because flows had entered the sea and could rend the skin of the baidarkas (sealskin-clad kayaks). This sparse and cryptic information suggests pyroclastic flows carrying boulder-sized pumice swept down the north and northeast flanks and into the sea. Such flows could voluminously reach down the short and steep run to water before debris avalanche added land to that coast in 1883 (plate 1).

Yet we identify on Augustine Island no mappable deposit definitely of 1812. At the likely focus of pyroclastic flows, north and northeast, five later eruptions also focused debrisvoluminously so in 1883,1976 , and 1986 . The 1883 debris avalanche deeply buried that lower volcano flank in coarse
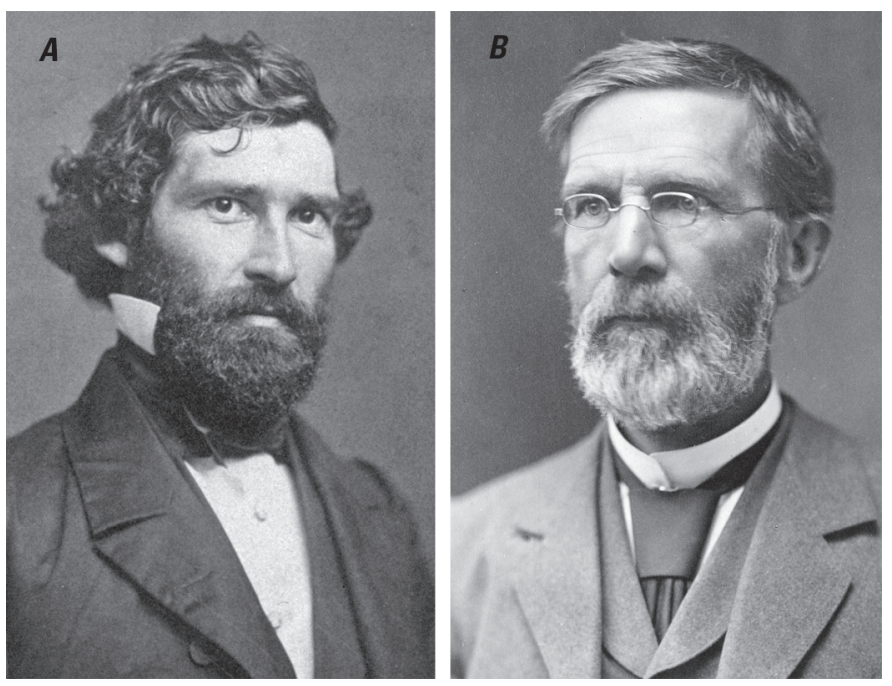

Figure 41. Photographic portraits of George Davidson. $A$, in 1850s (Bancroft Library, University of California, used by permission). $B$, about 1884 by photographer named "Miley," from B.A. Colonna Album, National Oceanographic and Aeronautics Administration (NOAA).

rubble and established a new coast more than $2 \mathrm{~km}$ beyond the old one. There's no seeing what lies below these deposits. But in our interpretation of some measured sections (plate 2) we speculate that a thin ash below the ash layer we identify with 1883 to be 1812 ash.

\section{Eruption}

1883 is the first Augustine eruption documented to some extent by contemporaneous written accounts: an unpublished logbook of the Alaska Commercial Company post situated atop the spit at English Bay, published summaries by Dall (1884), Davidson (1884), and Becker (1898), an unpublished letter and an unpublished mission report both of 1884, and field notes by J.E. Spurr in 1898 .

On the 6th of October 1883, Augustine Volcano - or Chernoburoy (variously spelt) as the Russians knew it — generated a tsunami and an ash plume experienced from English Bay $85 \mathrm{~km}$ away on the east mainland. The record book of the Alaska Commercial Company (1883) at Alexandrovsk (English Bay) records various routine data for 6 October 1883. Then this entry:

At this Morning at 8. $\underline{15}$ o'clock 4 Tidal Waves flowed with a westerly current, one following the other at a rate of 30 miles $p$. hour into the shore, the sea rising 20 feet above the usual Level. At the same time the air became black and foggy, and it began to thunder. With this at the same time it began to rain a finely Powdered Brimstone Ashes, which lasted for about 10 Minutes, and which covered all the parts of Land and everything to a depth of over 1/4 of a inch, clearing up at 9 o'clock A.M. Cause of occurrence: Eruption of the 
active Volcano at the Island of Chonoborough. Rain of Ashes commencing again at 11. o'clock A.M. and lasting all day.

And for 7 October:

Volcano ejecting fire and heavy black Clouds of Smoke all day long.

The geographer William Dall (1884) rushed into print summary information derived from George Davidson (USCGS) (fig. 41B) and from a Capt. Sands and a Capt. Cullie (Alaska Commercial Company) observed from English Bay and then the sea:

Smoke first arose from the peak in August. On the morning of Oct. 6 the inhabitants heard a heavy report, and saw smoke and flames issuing from the summit of the island. The sky became obscured, and a few hours later there was a shower of pumice-dust. About half-past eight o' clock the same day an earthquake wave, estimated at thirty feet height, rolled in upon the shore, deluging the houses on the lowland, and washing the boats and canoes from the beach. It was followed by others of less height. The ash fell to a depth of several inches, and darkness required lamps to be lighted. At night flames were seen issuing from the summit. After the first disturbances were over, it was found that the northern slope of the summit had fallen to the level of the. . . shore, and the mountain appeared as if split in two. ... The cleft . . crosses the island from east to west.

George Davidson, who for the USCGS mapped much of the Washington-Oregon-California coast in 1850-53 (fig. 41A) and the Alaska coast in 1867-69, was experienced with coastal ship captains and eyewitness reporting. Having been partly scooped of his own story by Dall, Davidson (1884) gives a more detailed account of Augustine's effects partly derived from "settlers and fishing-parties" at English Bay: About eight o'clock on the morning of Oct. 6, 1883, the weather being beautifully clear, the wind light from the south-westward, and the tide at dead low water, the settlers and fishing-parties at English Harbor heard a heavy report to windward (Augustin bearing south-west by west three-fourths west by compass). So clear was the atmosphere that the opposite of north-western coast of the inlet was in clear view at a distance of more than 60 miles.

When the heavy explosion was heard, vast and dense volumes of smoke were seen rolling out of the summit of St. Augustin, and moving to the north-eastward; and at the same time (according to a hunting-party in Kamishak Bay), a column of white vapor arose from the sea near the island, slowly ascending, and blending with the clouds. The sea was also greatly agitated and boiling, making it impossible for boats to land upon or to leave the island.

From English Harbor . . it was noticed that columns of smoke, as they gradually rose, spread over the visible heavens, and obscured the sky, doubtless under the influence of a higher current (probably north or northeast). Fine pumice-dust soon began to fall, but gently, some of it very fine, some very soft, without grit.

At about twenty-five minutes past eight A.M., or twenty-five minutes after the great eruption, a great 'earthquake wave, 'estimated as from twenty-five to thirty feet high, came upon Port Graham [English Bay] like a wall of water. It carried off all the fishing-boats from the point, and deluged the houses. This was followed, at intervals of about five minutes, by two other large waves, estimated at eighteen and fifteen feet; and during the day several large and irregular waves came into the harbor. The first wave took all the boats into the harbor, the receding wave swept them back again to the inlet, and they were finally stranded. Fortunately it was low water, or all of the people at the settlement must inevitably have been lost. The tides rise and fall about fourteen feet.

These earthquake waves were felt at Kadiak [Kodiak], where they are doubtless on the register of the coast-survey tide-gauge at that place.

An indirect but independent record of the sea waves striking the Kenai Peninsula mainland exists in a report of the Russian Orthodox priest heading the Kenai mission, Heiromonk Nikita, who after a visit of his southern parishes wrote on 28 May 1884:

Influenza Kenai, Ninilchik, Seldovia, Alexandrovsky [English Bay], nearly all children up to 2 years of age were swept away. At the same time this region suffered from innundation caused by the eruption of Chernabura volcano, which is about 60 miles across the straight from Alexandrovsky. The innundation so frightened natives of Alexandrovsky that they moved their huts to higher ground in one night. ${ }^{10}$

This report is consistent with Davidson's and Dall's that the largest sea wave was high enough to "deluge the houses" at English Bay.

The volcano evidently continued in eruption at least intermittently for weeks or months. Some time after 10 November 1883 (when in schooner Kodiak Captains Cullie and Sands approached Augustine Island), Davidson (1884) includes in his account:

The condition of the Island of Augustin or Chenaboura, according to the latest accounts, is this: At night, from a distance of fifty or sixty miles, flames can be seen issuing from the summit of the volcano; and in the day-time vast volumes of smoke roll from it.

\footnotetext{
${ }^{10}$ Russian Orthodox church records, Diocese of Alaska, Library of Congress (microfilm copy of Reel 1, Box 400, University of Alaska Anchorage Archives)
} 
Another entry in the Kenai Mission record by Heiromonk Nikita on 27 May 1885 reads:

Earthquakes still quite frequent here [at Kenai?] and

Chernabura is still smoking.

Davidson's (1884) account includes several obvious errors of observation or interpretation, including a Capt. Cullie description rendered into a fanciful figure (Davidson, 1884, $\mathrm{p}$. 188). A chagrined Davidson later tried to rectify this in a letter (unpublished) dated 5 November 1884 addressed to Prof. J.E. Hilgard, Superintendent of the USCGS. One of Davidson's late-1883 sources, Capt. Cullie of the Alaska Commercial Company at English Bay, had sailed past Augustine Island in June 1884. As reported in Davidson's November letter, Capt. Cullie saw from the north that:

.. from the summit a great slide of the mountain over half a mile broad had taken place towards the rocky boat harbor on the northnorthwestward. ${ }^{11}$ It appeared as if there had been a great sinking of the rocks under the summit leaving a face of wall overlooking the slide. Down this had poured the lava [sic] and erupted material to the base of the mountain and had pushed into the boat harbor and filled it up. In the upper part of lava [sic] outflow was issuing great volumes of white smoke. . .

A later record about Augustine's preeruption “boat harbor" exists in the field notes of USGS geologist J.A. Spurr (USGS archives):

Oct. 17 (1898)

Trader says here at Katmai that eighteen years ago [sic] three families from Kodiak went with families and baidarkas to St. Augustine Island to spend the winter. Built barabaras on the shore of a bay. The

\footnotetext{
${ }^{11}$ True azimuth to Burr Point is north to north-northeast. Capt. Cullie probably reports (correctly) magnetic azimuth, $22^{\circ}$ west of true azimuth.
}

mountain began to shake continually and finally they took their families off, while they stayed on themselves. Finally the mountain began to shake so violently that they put all their effects in their bairdarkas and started on a stormy day. Scarcely were they at the mouth of the bay when an explosion occurred, ashes, boulders, and pumice began pouring down and the barabaras were buried and the bay filled up with debris. At the same time there were many tidal waves, so the natives nearly perished with fright, yet finally escaped. ${ }^{12}$

Becker's (1898) published account mostly reiterates information in Davidson (1884) and Dall (1884) about events of 6-7 October 1883 but includes a few details from a climb in 1895 by Becker and his assistant Purington nearly to the summit and to the new dome (Becker, 1898, p. 29):

... steam escaped from countless crevices, most of them on the inner cone [that is, a new dome] . . . . masses were from time to time detached, rolling down to the bottom of the deep moat which separates the outer crater from the inner cone... . The inner cone [is] nearly as high as the outer rim.

\section{Burr Point Debris-Avalanche Deposit}

The landscape at the north-northeast shore of Augustine Island changed dramatically and suddenly on 6 October 1883. The deposit about Burr Point is fragmental diamict capped by pyroclastic flows (unit 83a, plate 1) — not exactly "lava" of Capt. Cullie's description. The intricately lumpy topography about Burr Point and the almost random distribution of

\footnotetext{
${ }^{12}$ Native-Alaskan barabaras are temporary plank huts. Baidarkas are woodframed sealskin-clad kayaks for hunting. Historical photographs of them can be seen in Cook and Norris (1998, chap. 2).
}

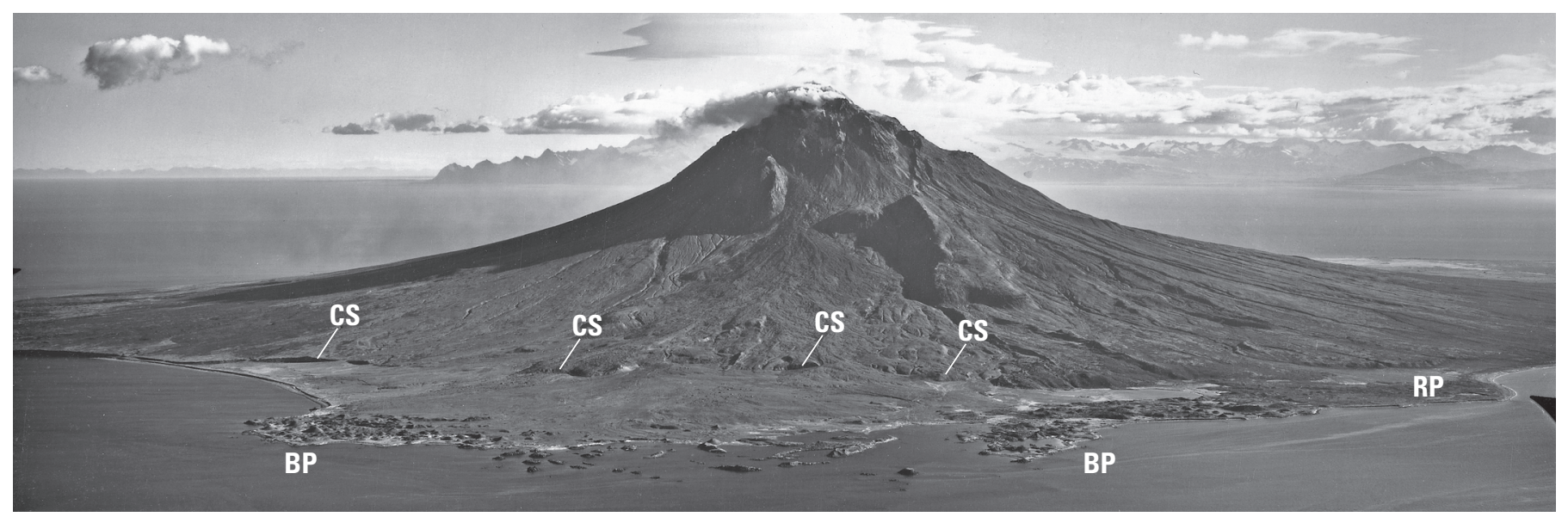

Figure 42. View of Augustine Volcano from the north showing hummocky deposit about Burr Point (BP) deposited by landslide (debris avalanche) of 6 October 1883. Cliffed shoreline (CS) that the 1883 avalanche overrode as it entered the sea. Debris-avalanche deposit is in turn overlain by light-colored pyroclastic-flow debris of 1883 (and 1935?). Smaller late-prehistoric Rocky Point avalanche (RP) lies just west. Summit point is the then-new 1964 dome. (USGS photograph by Austin Post, 3 September 1966.) 

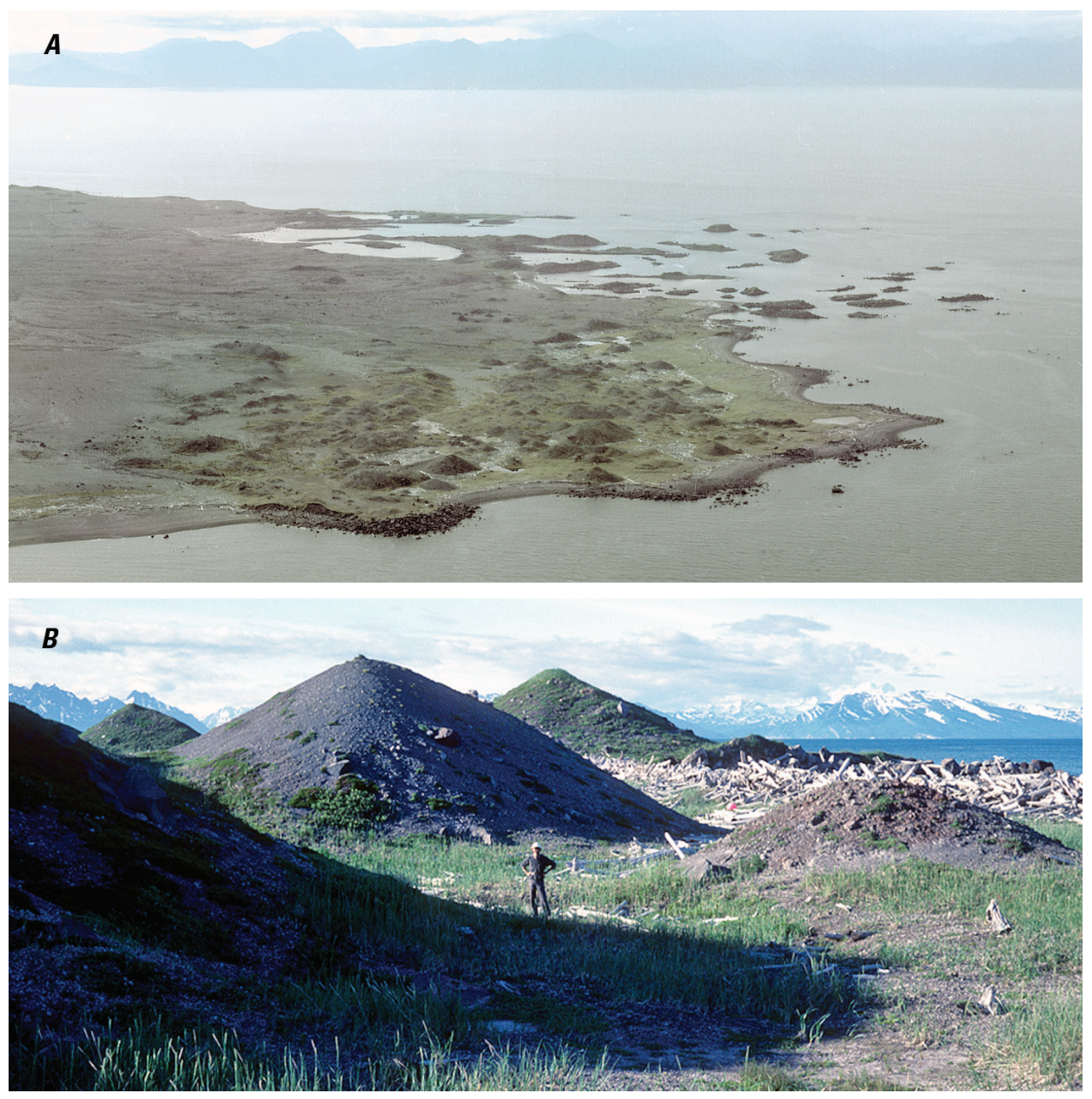

Figure 43. A, Close aerial photograph toward west-northwest showing eastern cluster of hummocks of 1883 Burr Point debris avalanche, Augustine Island. Northeast Beach on left. $B$, View northward along eastmost hummocks, Mount lliamna volcano in distance on skyline; compare with West Island hummocks (fig. 34). (USGS photograph by Richard Waitt.)

hummocks with relief as much as $30 \mathrm{~m}$ and steep (20-35 $)$ sides (figs. 2, 29, 42, 43A, 43B) - the freshest such deposit on Augustine Island - resemble the deposit of the great debris avalanche off Mount St. Helens on 18 May 1980. In the central coastal part, hummocks align in seaward-convex arms embracing the sea. This part of the moving flow thus evidently organized into discrete lobes just before movement ceased. Most of this hummocky debris lies seaward of a preeruption sea cliff: most of the avalanche swept into the sea.

Brecciated andesite fragments compose the Burr Point hummocks. Individual blocks are commonly as large as $5 \mathrm{~m}$; a few intact blocks are as large as $10 \mathrm{~m}$; one coastal slab is $25 \mathrm{~m}$ long and $9 \mathrm{~m}$ thick. Many of these large blocks are intact though much fractured, what Glicken (1996) calls "jig-saw" texture. The matrix between large blocks is pulverized andesite, an unsorted cobbly and pebbly sand diamict entirely of very angular clasts identical to the large blocks.

Several varieties of porphyritic andesite compose the blocks, in many places randomly thrown together-the gray with the reddish, the irregularly broken with the columnarly jointed. A few blocks as large as $4 \mathrm{~m}$ are of sintered vent spatter. A few hummocks incorporate fragile clasts of fall pumice, beds that must have mantled part of the north flank just before the 1883 eruption. Though carried to the coast within the avalanche, these loose materials were scarcely disrupted. Thus the flow was nonturbulent enough to raft some fragile blocks without disintegrating and assimilating them. Several hummocks 8 to $15 \mathrm{~m}$ high near the coast and 1 to $1.5 \mathrm{~km}$ back from it contain shattered, soft, yellow to brown andesite that apparently had been hydrothermally altered within the former cone.

A continuous, high sea cliff had been cut back into old fragmental debris on the north-northeast of Augustine Island (figs. 2 and 42, and plate 1). The cliff was probably cut into 1812 deposits, but in the seven decades after that eruption the sea may well have cut back to a pre-1812 sea cliff carved in underlying older deposits. This cliff was overridden and smoothed by the 1883 debris avalanche. 
For at least a couple months after the eruption there may have been a lagoon between the old sea cliff and the new hummocky deposit seaward, and this the origin of Davidson's (1884) and Dall's (1884) secondhand account (quoted above) from Capt. Cullie that the mountain "appeared as if split in two," the new island being separated from the main island by an east-west waterway, ${ }^{13}$ an area filled to above sea level by pyroclastic-flow deposits later in the eruption (see below).

The pre-1883 sea cliff remains unmistakable on aerial photographs of 1957. It becomes less conspicuous and less continuous on post-1976 and especially post-1986 aerial photographs as the scarp got more and more buried by the thick pyroclastic-flow deposits of these recent eruptions. The 1976 and 1986 pyroclastic deposits (see below) all but fill the former low area that had existed behind the Burr Point debrisavalanche hummocks since the 1883 eruption - a low analogous to Northwest Lagoon behind the West Island hummocky avalanche. The present coast of Burr Point is $1 \frac{1}{4}$ to $2 \frac{1}{8} \mathrm{~km}$ beyond the 1883 sea cliff (plate 1). Offshore islands extend to $2 \frac{2}{3} \mathrm{~km}$ beyond the sea cliff and submarine hummocky topography (fig. 11) extends $4 \mathrm{~km}$ beyond.

A conspicuous straight, sharp-crested lateral levee 3 to $10 \mathrm{~m}$ high containing blocks of porphyritic-andesite dome rock as large as $6 \mathrm{~m}$ marks the west margin of the debrisavalanche path. The most upslope part of the levee overlies the North Slope lava flow at altitudes 700 to $450 \mathrm{~m}$ (figs. 30, 39). At altitude $80 \mathrm{~m}$ a slightly older levee sticks beyond the outside edge of the main levee. This relation suggests the 1883 debris avalanche had two pulses: a lesser one just before the main one. Below altitude $200 \mathrm{~m}$, the east side of the levee is partly buried and in low reaches overtopped by pumiceous pyroclastic flows of the 1976 and 1986 eruptions.

In contrast to the West Island debris-avalanche deposit, the Burr Point deposit is nearly devoid of vegetation, has numerous

\footnotetext{
${ }^{13}$ Directions in the historical accounts are magnetic rather than true. (At one point Davidson [1884] specifies "compass" direction.) To obtain azimuth with respect to true meridian, rotate the compass directions and azimuths about $22^{\circ}$ clockwise.
}

offshore islands not yet consumed by the sea, and is only locally and discontinuously carved back into sea cliffs. Burr Point is thus geomorphically much younger than West Island. The hummocky topography about Burr Point is only slightly sharper than that at adjacent Rocky Point, but overlying soil on the Rocky Point deposit shows it to be older than the Burr Point diamict. Both deposits have offshore remnants, but those at Rocky Point are wave beveled to rocky shoals rather than remaining as island hummocks - further evidence of Rocky Point's relative antiquity. Many of the central and western hummocks of the Burr Point deposit were partly or wholly overtopped by pumiceous pyroclastic flows of 1883, 1976, and 1986. Deposits of these flows partly bury the southern (upslope) hummocks.

Some of the Burr Point hummocks are overlain by an organic soil, which contains the distinctive $1-3 \mathrm{~cm}$ white-silt ash of the 1912 Katmai eruption. In distal (seaward) places this Katmai ash is underlain by a thin organic horizon that overlies a gray silt ash, apparently of the 1883 eruption. In proximal low areas between hummocks this gray ash is in places overlain by 30 to $200 \mathrm{~cm}$ and more of massive sand, apparently pyroclastic-flow deposit (Kamata and others, 1991, figs. 4, 5). This fall ash and the overlying pyroclasticflow deposit, both of them overlying and among Burr Point hummocks, are evidence that the debris avalanche came early and perhaps inaugurated the 1883 Augustine eruption - as the Mount St. Helens landslide (debris avalanche) inaugurated that 18 May 1980 eruption.

When measured in 1988-92 on large coastal boulders of the 1883 debris avalanche, the largest thalli of a black-dotted pale-yellow-green lichen (Rhizocarpon geographicum?) were $15-17 \mathrm{~mm}$ in intermediate diameter. Fast-growing rugose yellow lichen meanwhile had radiated out 8 to $21 \mathrm{~cm}$ in diameter.

\section{Bay-Mud Clasts}

Atop the coarse diamict but beneath the gray ashfall deposit, the north sides and tops of several coastal avalanche hummocks are draped by exotic rounded pebbles of argillite, granite, diorite, gabbro, amphibolite, hornfels, vein quartz,

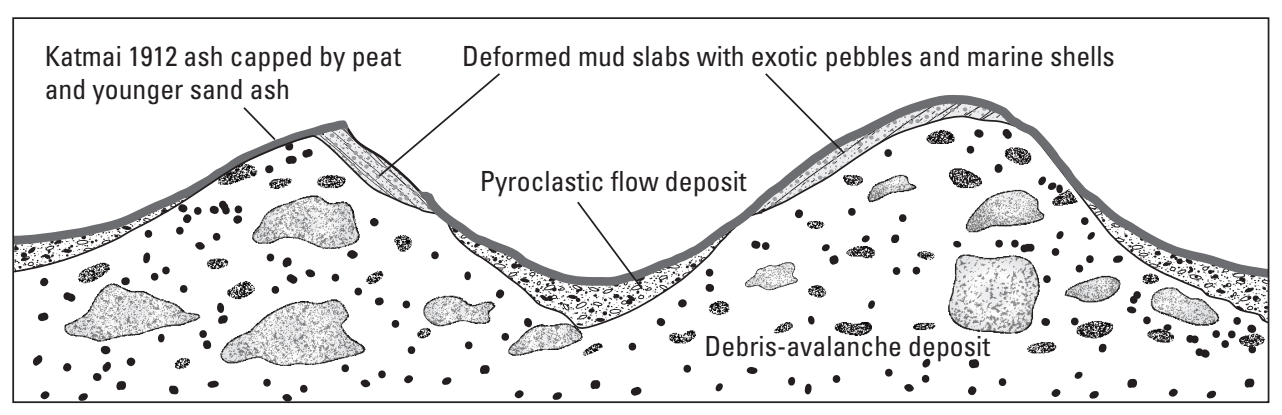

Figure 44. Schematic sketch of stratigraphic relations at seaside hummocks east of Burr Point. Bouldery debris-avalanche deposit is overlain by pyroclastic-flow deposit (light stipple in lows) and by Katmai 1912 ash and younger sand ashes interlayered with peat (heavy line). Deformed slabs (bedding lines and light stipple) of compact, fissile mud containing marine shells and rounded small pebbles of diverse exotic lithology are draped over some hummocks. Marine shells (see explanation in text) from these slabs are radiocarbon dated at 6,210 and 7,170 yr B.P. (table 2). 
and others. These stones affiliate with discontinuous slabs of deformed mud $1 / 2$ to $2 \mathrm{~m}$ thick and as long as $15 \mathrm{~m}$ that locally overlie these seaward slopes of coastal hummocks (fig. 44). One pebbly-mud clast lies atop a hummock $320 \mathrm{~m}$ back from the coast. Most of the mud clasts are rich in broken shells of several marine species. Radiocarbon analyses of shells from two different coastal hummocks yield ages of 6,210 and $7,170 \mathrm{yr}$ B.P. (table 2). The mud clasts lie as much as 10 to $13 \mathrm{~m}$ above storm high water registered by the upper limit of stranded driftwood and fishing floats.

The mud clasts are slabs of bay mud scraped up by the debris avalanche as it plowed into offshore sediments. Picture a carpenter's plane shaving off a layer of wood, leaving more wood below. Repeated planings bite into deeper and deeper wood. The shaved-off strip laid over the foreface of the blade is analogous to the bay-mud slabs laid over the foreface of coastal hummocks. Leading parts of the debris avalanche, deposited below sea level and forming the farthest-offshore islands, must have scraped off the surfacemost mud, allowing trailing parts of the avalanche to bite into middle and early Holocene mud. Modern rocky snow avalanches illustrate that an avalanche moving down across snowpack can in this manner scrape off the upper layers of snow and lay it atop the moving debris but leave most of the snowpack beneath the avalanche (Waitt and others, 1994, fig. 14). The shelly mud slabs atop hummocks are evidence that the Burr Point avalanche entered the sea fast and energetically. The inland hummock capped by shelly mud shows that before October 1883 the bay and its Holocene mud reached more than $1 / 3 \mathrm{~km}$ inland of the present shore.

\section{Evidence of High Water}

Davidson (1884) tells of a Native party at Augustine when the eruption started: "the sea was greatly agitated and boiling, making it impossible for boats to land on or leave the island." In his 1898 fieldnotes Spurr says of a Native party at Augustine when the bay on the north-northeast suddenly filled with debris "there were many tidal waves." These minimal second- and third-hand accounts show that Augustine's sudden debris generated sea waves, but it's hard to know their height.

The shelly megaclasts overlying several Burr Point hummocks imply that sea waves reached at least that high -10 to 13 meters above normal spring-high tide. (Or up to $12 \mathrm{~m}$ if we subtract from this a 1-m rise of the island above sea level during the 1964 earthquake [Plafker, 1969])

Besides the deformed shelly clasts of mud atop central hummocks about Burr Point are discontinuous sand bodies containing marine shells on some outer Burr Point hummocks as much as $3 \mathrm{~m}$ above spring-high tide (Keskinen and Begét, 2006). ${ }^{14}$ On some outer hummocks isolated driftwood, some of it mostly buried by 1883 pyroclastic-flow deposit, is stranded 3-5 $\mathrm{m}$ above highest modern tides. And some hummocks seems oddly planed off by water well above high tide. Though only recently and incompletely explored, these

\footnotetext{
14 These results are from occasional brief fieldwork in 2002, 2004, 2006, and still in progress.
}

deposits and effects near Burr Point give new evidence of the tsunami impelled by the 1883 landslide as it slammed into the sea (see below).

\section{Pyroclastic-Flow and Surge Deposits}

Overlying and partly filling a moat landward of the Burr Point debris-avalanche deposit are a few centimeters of laminated silt ash, overlain by nonsorted and massive pebbly sand 0 to $2 \mathrm{~m}$ and more thick, in turn grading up to a reddish-brown granular medium sand 5 to $10 \mathrm{~cm}$ thick (unit 83p, plate 1).

Near Burr Point the pebbly-sand phase is cut by vertical pipes 2 to $30 \mathrm{~cm}$ in diameter of intensely oxidized openwork lithic pebble gravel with clasts as large as $8 \mathrm{~cm}$. The oxidation is orange to brown to yellow coatings on clasts, which suggests these structures were hot fumaroles though rootless. The source of gas (steam) would have been underlying water or wet sediment of a shallow bay that the 1883 avalanche and
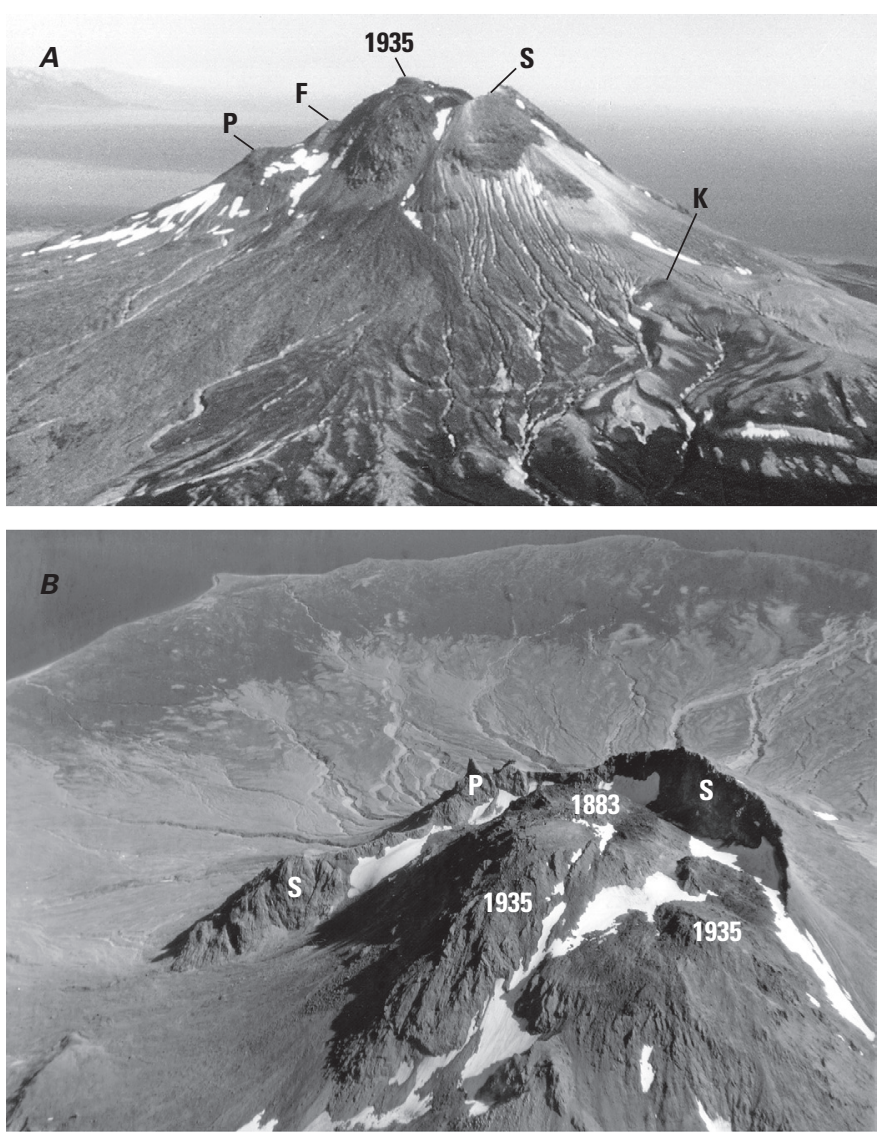

Figure 45. Oblique aerial photos of Augustine Volcano. $A$, toward northeast, showing 1935 dome draped over west rim of 1883 crater; P, F, S, K identify domes P, F, summit, and Kamishak. USGS photograph by Bruce L. Reed, August 1959. B, toward east-southeast, showing 1883 and 1935 domes. Arcuate scarp behind 1883 dome is scar left by 1883 landslide, which beheaded composite summit dome (S) including pinnacles area (P). (USGS photograph by Austin Post, 24 August 1960.) 


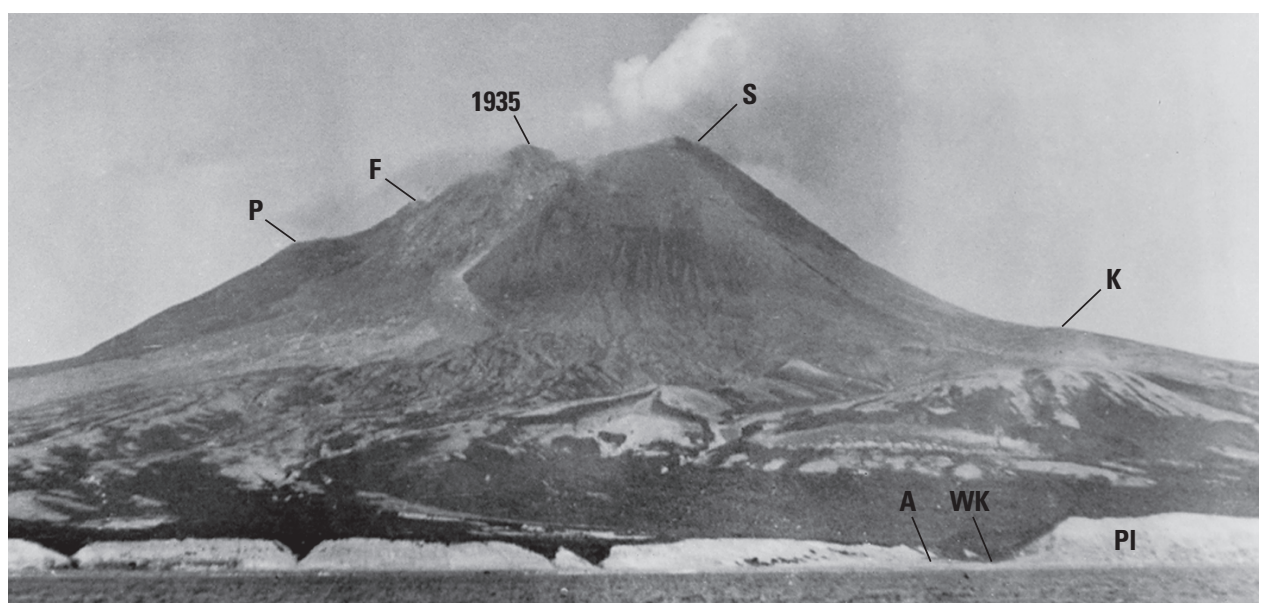

Figure 46. View of Augustine Volcano from southwest showing large steaming dome and below it a light-colored fan of debris shed down into "west-southwest swale." $\mathrm{P}, \mathrm{F}$, and $\mathrm{S}$ identify domes P, F, and compound summit done; 1935, growing 1935 dome. At midflank, K, Kamishak dome. On coast, A, Augustine Creek; WK, West Kamishak Creek, PI, Pleistocene(?) landslide block. (Photograph by Kenai Peninsula resident Steve Zawistowski, 9 July 1935.)

pyroclastic flows had filled. The fumaroles were vigorous enough to eject upward the original sand-granule matrix. This massive-sand deposit, which overlies the rocky debrisavalanche deposit with no intervening soil, is of a pyroclastic flow or surge. The lack of a soil shows that it occurred soon after the debris avalanche.

The pyroclastic deposit in places ponded at least a few meters deep against the upslope sides of hummocks and even large boulders. The deposit thins to nil over the debrisavalanche hummocks. Thus it smooths the original relief of the debris-avalanche deposit by irregularly filling lows. The sand deposit is thickest in the western and southern part of the hummock field and thins to a few centimeters at the eastmost coastal hummocks.

Our excavations by small hand shovel are no deeper than $2 \mathrm{~m}$. In deepest areas inland from Burr Point this material could be $6 \mathrm{~m}$ or more thick. Judging from the scanty hints in contemporaneous accounts such as Davidson's (1884 [quoted above]), eruptive incandescence and ashclouds on Augustine's northeast flank lasted many weeks and perhaps months. These may have included voluminous pyroclastic flows that eventually filled a lagoon seaward of the preeruption sea cliff landward of the debris-avalanche deposit - a lagoon like that still behind West Island. Before it was filled, this lagoon could have been Capt. Cullie's east-west waterway behind a new island (see above).

Rare lithic bouldery deposits on Augustine's other flanks, as on the south shore at the mouth of Augustine Creek, are immediately overlain by — thus shortly predate - the Katmai 1912 ash. Perhaps some of these too are 1883 pyroclastic-flow deposit.

\section{Lava Dome}

A sizable, broad lava dome grew in the newly evacuated crater near the summit, shown on several photographs of
Augustine Volcano taken between 1895 and 1960 (figs. 40B,C, and $D$ and 45). Becker (1898) called it the "inner cone" of the crater. He reported that in 1895 it still emitted steam profusely while rocks copiously rolled from its surface. The large gap in the pre-1883 rim showing on photos from the west was later filled by the 1935 dome. The 1883 dome was incorporated into and built over by a succession of later domes-1935, 1964, and especially 1976 and 1986 and now 2006. None of the primary 1883 dome remains.

\section{Discussion}

In the wake of Augustine's 6 October 1883 eruption, Dall (1884) and Davidson (1884 and unpub. 1884 letter) reported second-hand information on dramatic changes to the volcano, including a collapse of the summit area northward (quoted above). Three decades later (in 1913) Robert F. Griggs briefly stopped by the north side of Augustine Island and inferred that the Burr Point deposit was a great recent landslide. After visiting Katmai 2 years later, he noted how similar was the hummocky deposit about Burr Point to that of the 1912 Mageik landslide at Katmai (Griggs, 1920, p. 341). The slide that formed Burr Point was doubtless the cause of the series of extraordinary waves (tsunami) that, according to the log of Alaska Commercial Company (1883) and according to Davidson (1884) and Dall (1884), swept at least $6 \mathrm{~m}$ high into English Bay harbor on Kenai Peninsula on the morning of 6 October 1883.

In Davidson's November 1884 letter, Capt. Cullie's "white smoke" evidently issues from the top of pyroclastic flows, not lava, and it reminds of the first images of Katmai after the 1912 eruption that inspired the name "Valley of Ten Thousand Smokes" (Griggs, 1922). The vertical openwork pipes we note in the shallow subsurface of the 1883 
pyroclastic-flow deposit are consistent with Capt. Cullie's description 8 months after the Augustine eruption.

\section{Eruption}

\section{Lava Dome}

Remnant of a 1935 dome of gray porphyritic andesite forms a prominent point on the north-northwest of the summit dome complex (unit 35d, plate 1; fig. 16) and a broad dome lobe that descends the west-southwest summit cone. The 1935 dome is identified by several sources: (1) contemporaneous shipboard photographs taken by Kenai Peninsula resident Steve Zawistowski in July 1935 showing the steaming westsouthwest lobe (fig. 46); (2) USGS oblique aerial photographs taken in 1944 by John Reed, in 1959 by Bruce L. Reed, and in 1960 by Austin Post - all before large changes to the summit area during the 1963-64 and 1976 eruptions; and (3) Detterman $(1968,1973)$, who in 1967 in the field distinguished the then-new 1963-64 dome from remnants of older domes. The 1944, 1959, and 1960 photographs actually show two domes: one (1883) inside the 1883 crater, the other (1935) on and outside the west rim (fig. 45).

\section{Flank Deposits}

High on the southwest flank downslope of the 1935 dome heads a fan of rubble whose angular andesite dome-rock boulders are as large as $6 \mathrm{~m}$ (unit 35b, plate 1). This material is similar to coarse lithic pyroclastic-flow deposits on the south flank of the 1963-64 eruption. Because the southwest fan lies directly downslope from the 1935 dome, we interpret it to have been emplaced then.

Zawistowski's July 1935 photographs from a boat off the southwest coast show light-colored fresh deposits in westsouthwest swale, clearly recently shed downslope from a steaming, active dome (fig. 46). Some of the pyroclastic-flow deposits in this broad swale that we map with the 1964 eruption may include indistinguishable similar coarse debris from 1935.

\section{3-64 Eruption}

The timing and behavior of an eruption between October 1963 and August 1964 is described by Detterman (1968), who mapped on Augustine Island in 1967 when those effects were fresh and unambiguous. The dome and south-flank deposits remain well exposed.

\section{Lava Dome}

The 1964 eruption built a porphyritic-andesite dome (unit $64 d$, plate 1) that crowns an old summit-dome complex that had been decapitated to form the 1883 debris avalanche (figs. $12,19)$. The $1963-64$ dome flowed only 100 to $150 \mathrm{~m}$ down the south slope.

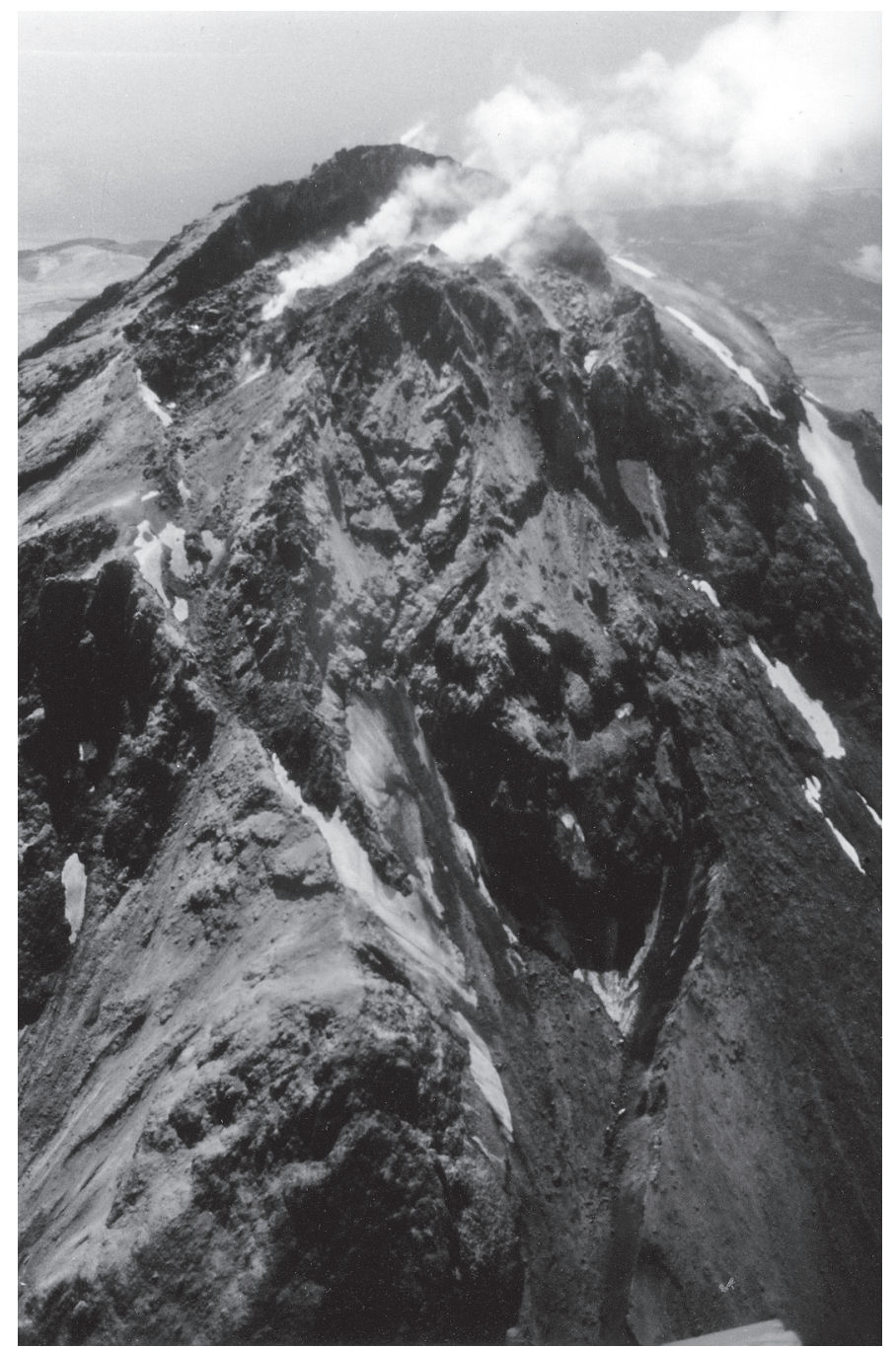

Figure 47. View south-southeast of summit-dome complex showing 1976 dome nested below summit. (Photograph by Jürgen Kienle, 27 July 1984.)

\section{Pyroclastic-Flow and Lahar Deposits}

The south-southeast flank bears several broad swaths of coarse rubble, the largest $2 \mathrm{~km}$ long and as wide as $1 \mathrm{~km}$. The rubble is nonsorted and angular, generally boulder gravel. Clasts are as large as $7 \mathrm{~m}$ but generally smaller than $3 \mathrm{~m}$, comprising largely dome-rock debris but also 2 to 15 percent pumice. The debris displays an intricate series of downslopetrending paired levees as high as $4 \mathrm{~m}$, evidence of emplacement by several pyroclastic flows. All these coarse-rubble patches (unit 64p, plate 1) lie within the area of fresh 1964 deposits mapped by Detterman (1968, fig. 1; 1973).

The 1964 rubble is now heavily but discontinuously coated by moss; by 1990 there were well-established groundcreeping blueberry with stems as thick as $0.7 \mathrm{~cm}$ and a few starts of alder. The deposit is readily distinguishable from adjacent 1976 deposits by the coarseness of the 1964 deposit 
and its greater vegetation. East of the eastmost inlier exposing Pleistocene deposits, remnants of the coarse lithic 1964 flows are surrounded and veneered by finer and far more pumiceous 1976 flows. Because the 1976 flows feather out downslope into discontinuous patches, the map boundary (plate 1) between 1964 and 1976 deposits is in places arbitrary.

\section{Ballistics}

Large angular blocks of gray, slightly vesicular, porphyritic andesite lie scattered about upland surfaces of the middle and lower south and southeast volcano flanks, an area of 1964 ballistic fall denoted by Detterman (1968, fig. 1). At a distance of $2.2 \mathrm{~km}$ south of the 1964 dome summit, these blocks are $30 \mathrm{~cm}$ in diameter.

Computed using variable but low drag coefficients developed by Waitt and others (1995) for the 1992 eruptions of Mount Spurr volcano, since revised into online program "Eject!" by Mastin (2001), minimum ejection velocities for the southside Augustine ballistic blocks are between 150 and $170 \mathrm{~m} / \mathrm{s}$. Such velocities are well within the range generated by shallow but powerful Vulcanian-type explosions from historical eruptions of several other volcanoes.

\section{Eruption}

Augustine's 1976 eruption is better chronicled than earlier ones - in summary by Kienle and Forbes (1976), in detail by Johnston (1978, p. 16-28), and the sequence of airborne plumes by Kienle and Shaw (1979). Augustine erupted explosively from 22 to 25 January and from 6 to 8 February. During the explosive phase, pumiceous pyroclastic flows descended several flanks, though most voluminously the north. In middle to late February and especially in middle April, the volcano built a large summit dome (figs. 47, 48A), which truncated and incorporated the 1883 dome and part of the 1935 dome. During episodes of dome growth, the steep north edge of the dome repeatedly sloughed, descending the north flank as lithic pyroclastic flows. The 1976 dome was in turn incorporated by the 1986 dome and buried by very coarse 1986 proximal fall.

Johnston (1978, p. 29-35) documented stratigraphy of the main north-flank pyroclastic deposits, but before publishing it he perished in the Mount St. Helens 1980 eruption. More complete stratigraphy in 1988-89 (Kamata and Waitt, 1989; Kamata and others, 1991) incorporates the earlier studies as well as material culled from Johnston's unpublished field notes and manuscript fragments. The north-flank stratigraphy is known in far more detail than can be portrayed by the geologic map (plate 1).

\section{Pyroclastic-Flow, Surge, and Lahar Deposits}

During field mapping in 1988-93, degree of vegetation readily distinguished pyroclastic-flow deposits of the 1976 eruption low on the volcano flanks from adjacent ones of 1986. The 1986 flows were scarcely vegetated, only a few grass sprigs and
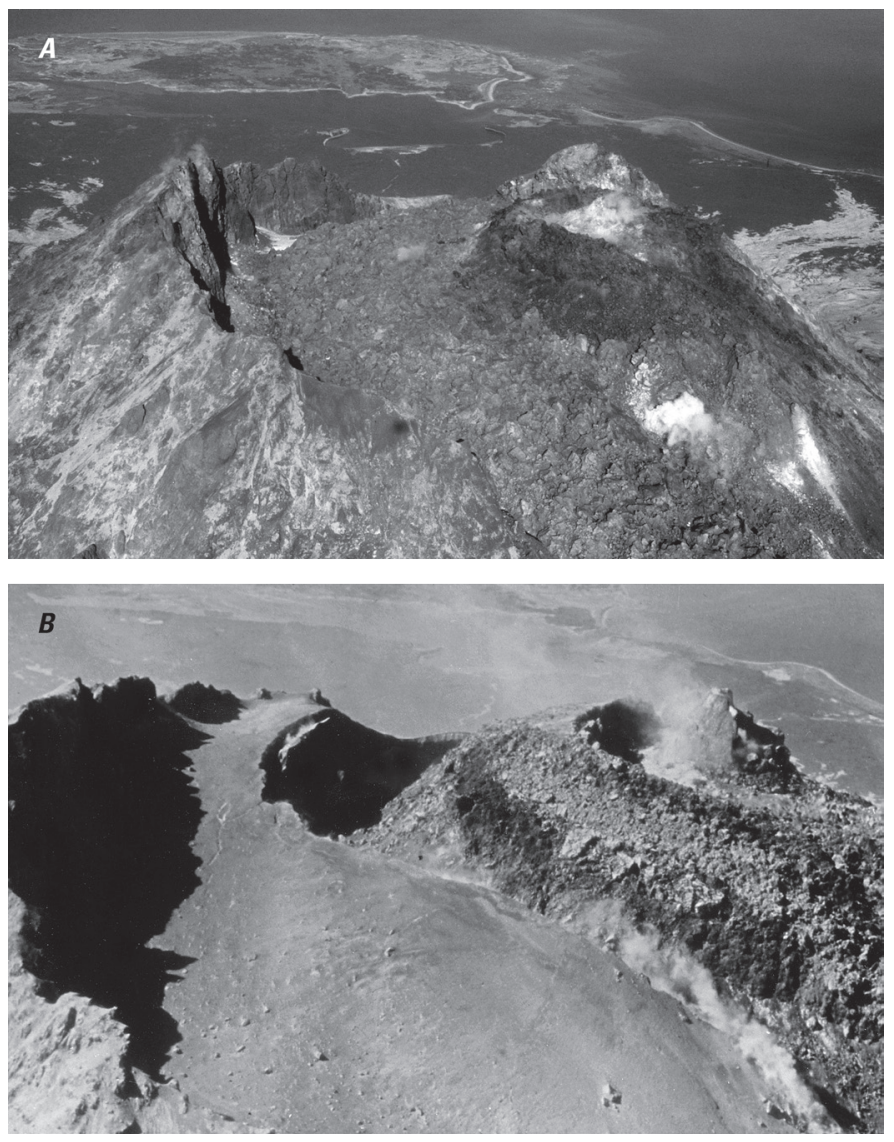

Figure 48. Views westward of Augustine Volcano summit area. $A$, showing 1976 dome with scarp and moat separating it from 1964 and prehistoric dome complex to south. (Photograph by Jürgen Kienle, 27 August 1985.) B, Similar view of new 1986 dome and smooth-topped fill after 1986 eruption. (Photograph by Betsy Yount, 24 August 1987.)

only the smallest blueberry starts. The similar 1976 flows were covered as much as 15 percent by grass and contained groundhugging blueberry plants with stems as thick as $0.5 \mathrm{~cm}$. Aerial photographs at 1:24,000 scale taken in August 1976 show the distribution of pyroclastic flows just after the 1976 eruption. Comparing these airphotos to those taken in 1986 and 1990 further aided our distinguishing 1976 from 1986 flows.

North-flank 1976 pyroclastic flows project beyond the north and northeast margins of the covering 1986 pyroclastic flows. They comprise two lithologic varieties: pumiceous flows that on the northeast were mobile enough to approach and reach the sea (unit 76p, plate 1); and overlapping lithic flows later shed from the growing dome that spread not quite as far (unit 76l). Both varieties contain banded (brown to white) pumice, especially conspicuous in the pumiceous flows. The pumiceous flows have intricately lobate marginal scarps 1.5 to $3 \mathrm{~m}$ high. On the north-northeast are two sets of overlapping pumiceous flows. They contain pumice blocks as large as $1 \mathrm{~m}$ but typically 10 to $50 \mathrm{~cm}$, and they also include many breadcrusted bombs, some of them well banded. These pumiceous flows were emplaced in 
the early, most explosive phases of the eruption - in late January and early February 1976 (Johnston, 1978; Kienle and Forbes, 1976; Kamata and others, 1991). Airphotos of 1976 show that on the north-northwest flank between Burr Point and west of Grouse Point, 1976 pyroclastic flows are distributed similarly to those that in 1986 spread down these same shallow vales.

Of a once-continuous lithic fan from the 1976 dome, only a toe on the north-northeast is unburied by 1986 flows. Details of the lithic flows are thus lost. In the main patch of 1976 flows on the lower north-northeast flank (plate 1), the toes of lithic pyroclastic-flow deposits (unit 76l) overlap more-extensive pumiceous ones (unit 76p). These lithic flows contain blocks rarely as large as $6 \mathrm{~m}$, commonly as large as $1 \mathrm{~m}$, and contain almost no pumice. Most or all of them must have been emplaced during growth of the dome beginning in late February but mostly in April 1976, when the rapidly growing hot dome repeatedly sloughed flows down the north flank (Kienle and Forbes, 1976; Johnston, 1978).

Near Burr Point a very fine sand to silt ash apparently of a 1976 pyroclastic surge (Kamata and others, 1991) extends as much as $1 \frac{1}{2} \mathrm{~km}$ beyond the limits of 1976 pyroclastic flows. It is stratigraphically separated from underlying 1883 pyroclastic-flow deposit by as much as $18 \mathrm{~cm}$ of peat that locally contains the Katmai 1912 ash. According to David Johnston's field notes taken at Burr Point in August 1976, Hans-U. Schmincke found that window glass of the corrugated-steel research hut had been broken outward. Thus this surge, which apparently occurred at 02:17 local time on 24 January (Kamata and others, 1991, fig. 10), first lofted over a protecting ridge just southwest to create a negative pressure outside the hut in its lee, popping the windows outward. Then an arm of the surge skirting the ridge on the south (Kamata and others, 1991, fig. 2) ripped off part of the south wall of the hut and scorched and burned mattresses inside. An outhouse overturned northward had its bottom burned; the undersides of upturned alder roots too were scorched. ${ }^{15}$ Plastic just inside the research hut's broken-out east window partly melted, but plastic farther back in the hut had not. This led Johnston to surmise the heat had been unidirectional (through the window) and brief - seconds rather than minutes. In a lab oven he melted a plastic papertowel holder to approximately the condition of "droop" of the towel holder that had hung just below the window in the Burr Point hut (fig. 49). Temperature would have been around $700^{\circ} \mathrm{C}$ for 5 seconds, or $500^{\circ} \mathrm{C}$ for 15 seconds. Heating at 600 to $500^{\circ} \mathrm{C}$ for 5 seconds fails to yield the required "droop" in the plastic. In 1988 the deposit of this surge still lay a few centimeters thick in protected, unswept corners inside the hut. It is largely eroded from the surrounding rocky landscape but in low areas extends as a discontinuous lamina to the curving coast of the bay and thus to an unknown distance offshore.

In a few northside swales the pumiceous pyroclastic flows emplaced during the early part of the 1976 eruption mixed with the winter snowpack enough to transform

\footnotetext{
${ }^{15}$ Some information here culled from David A. Johnston's 1976-79 field notes and manuscript fragments apparently of 1978-79.
}

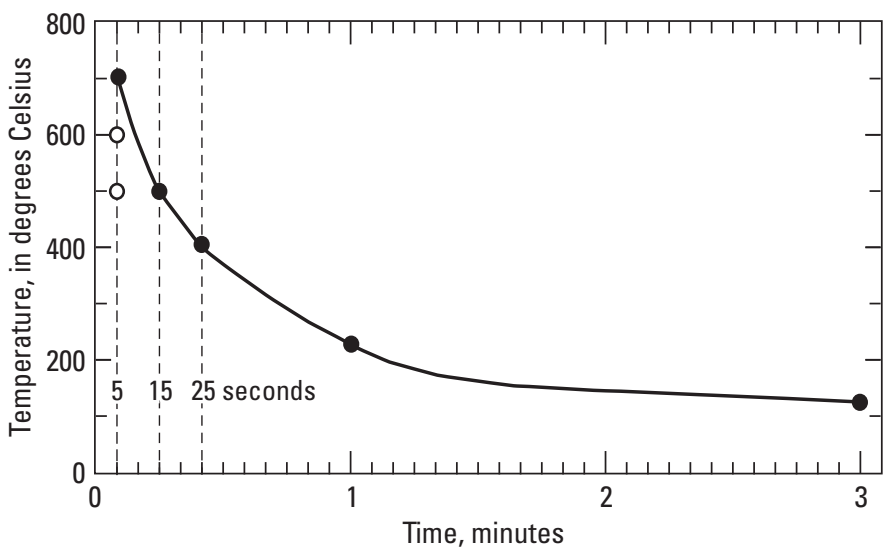

Figure 49. David A. Johnston's "isodroop" curve illustrating time and temperature conditions in a laboratory furnace to reproduce the degree of drooping of a plastic paper-towel holder just inside a window of the Burr Point research hut that had partly melted in a hot blast on 24 January 1976. Open circles depict conditions of tests in which degree of melting was less than observed. Data imply that temperature was very high if the duration of heat wave was short. (Redrawn from illustration for talk [Johnston, 1977] and in unpublished manuscript by Johnston of vintage 1978-79.)

downslope into hybrid flows or lahars (included in unit 76p). Similarly on the east flank above altitude $120 \mathrm{~m}$ in the gully that enters the coast at East Point, the pumiceous 1976 deposits look like those of normal pyroclastic flows with pumice-rich broadly lobate termini 1 to $2 \mathrm{~m}$ high, feathering out on vegetated adjacent highs. But where the gully is narrow and sinuous in its last $900 \mathrm{~m}$, the flow(s) had momentum to flow nearly straight, running $3 \mathrm{~m}$ up on sharp bends. The deposit in this lower reach contains uncharred wood and apparently no charcoal, evidence that it was cool. The apparently hot flows are nearly identical lithologically to the apparently cool ones, and the transition one to the other is gradational. The two cannot be distinguished systematically, so they are mapped as one unit.

The 1976 pumiceous pyroclastic flows descended swales and gullies on other flanks, overriding older fragmental debris nearly to the coast. These deposits are similar to the more extensive ones on the north flank and are similarly rich in banded (brown to white) pumice but generally contain lithic blocks only as large as about $2 \mathrm{~m}$. On the southeast flank, alder sticks imbedded in the tops of flows are only browned, not blackened to charcoal-evidence that while descending the cone, the flows cooled by incorporating snow. Some of the distal reaches of south-flank 1976 pumiceous pyroclastic-flow deposits, as in Augustine Creek, blend downgully into more compact, apparently waterlaid deposit. Near the mouth of a gully $0.8 \mathrm{~km}$ northeast of Southeast Point, such a 1976 lahar rode up $8 \mathrm{~m}$ high on an outside bend. By routine superelevation methodology (Chow, 1959; Waitt, 1989), this runup suggests a flow velocity of at least $12 \mathrm{~m} / \mathrm{s}$. Experiments in a large flume suggest actual velocity in this circumstance could 


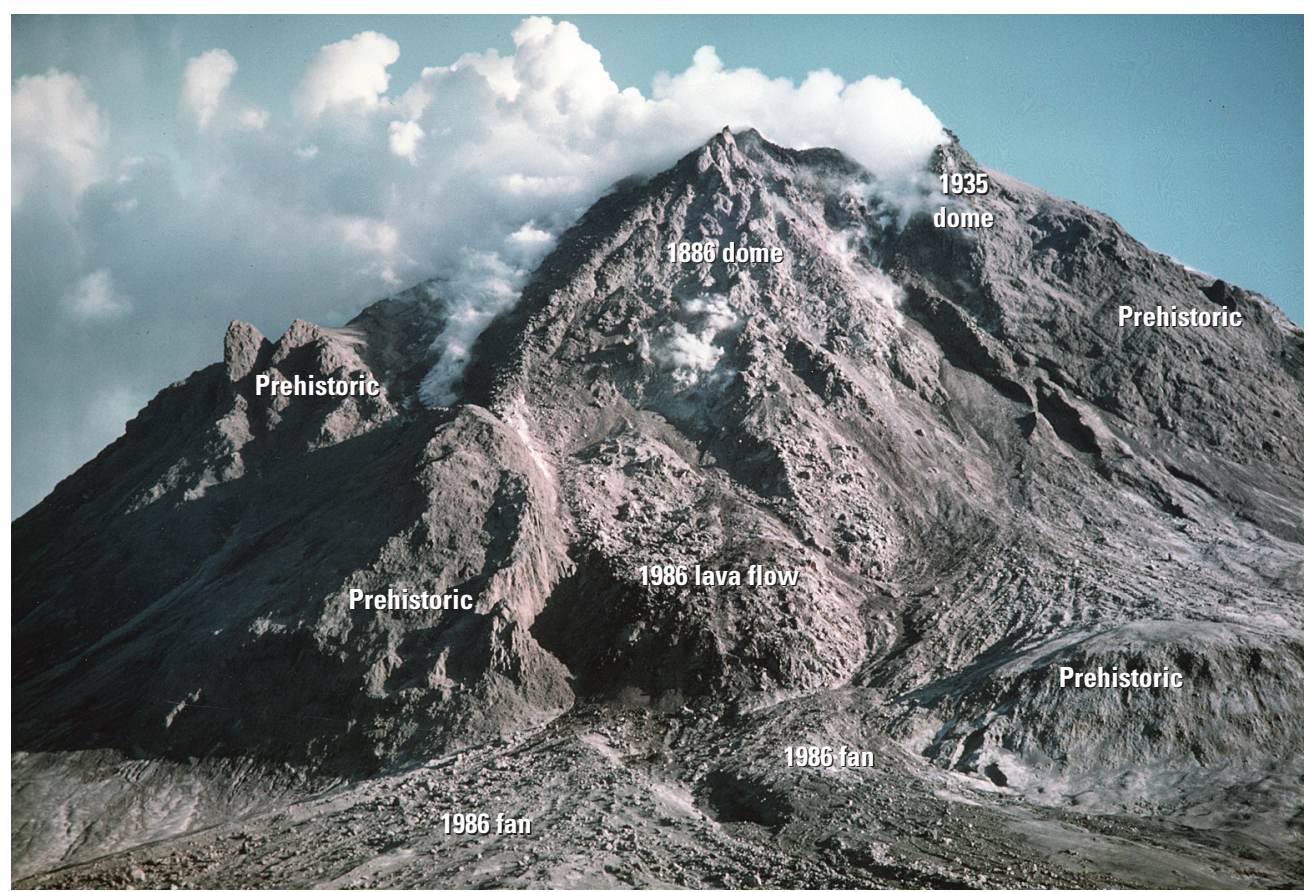

Figure 50. View southward in then-new 1986 dome and lava-flow tongue at its base. (Photograph by Jürgen Kienle, 14 July 1986.)

be slightly higher than by the superelevation equation around a bend (Iverson and others, 1994).

\section{Eruption}

Augustine Volcano erupted between 27 March and 31 August 1986. It sent scores of pyroclastic flows down its north and northeast flanks while also erupting a new dome in the summit area (Yount and others, 1987; Swanson and Kienle, 1988). The pyroclastic flows ranged from highly pumiceous to entirely lithic (disintegrated hot dome rock). As Johnston (1978) had inferred of the 1976 eruption, Roman and others (2006) argue on petrologic evidence that mafic magma injected from below induced the 1986 eruption.

\section{Lava Dome and Agglutinate}

The 1986 dome andesite (unit 86d, plate 1) forms the prominent part of summit area viewed from the north (figs. 2, $50,51) \cdot{ }^{16}$ As the dome grew it incorporated the large dome that had been emplaced there in 1976, which had incorporated part of the 1935 dome and all of the 1883 dome. The 1986 dome thus embodies four successive domes emplaced across a century. As the dome grew in 1986, it shed numerous lithic

\footnotetext{
${ }^{16}$ This discussion written between 1992 and 2003. In January-March 2006 a new eruption blew out part of the 1986 dome and emplaced a new dome, filling the former moat south of 1986 dome and otherwise changing summitarea topography.
}

pyroclastic flows down the north and northeast flanks. Map unit $86 \mathrm{~d}$ includes a lava tongue that flowed from the north base of the dome late in the 1986 eruption. The composite summit dome is larger than was the summit just before the 1883 eruption shown by Doroshin's (1870) sketch (fig. 40A).

A crescent-shaped bench south of 1986 dome is underlain by spatter and blocky, very angular cobble and boulder fragments of dome rock laid in numerous beds 1 to $3 \mathrm{~m}$ thick (figs. $48 B$ and 52). They apparently are agglutinate and proximal-fall beds (unit $86 \mathrm{~g}$ ). By its morphology the feature could be (and has been) mistaken for a truncated remnant of 1976 dome debris, but Jürgen Kienle's successive photographs of the area show that neither this smooth-surfaced bench nor the fragmental deposits composing it existed before 1986. They can only have accumulated during that eruption.

\section{Pyroclastic-Flow and Lahar Deposits}

The largest pyroclastic flows of 1986 lost at least $1 \mathrm{~km}$ in altitude (from summit) while extending $4 \mathrm{~km}$ to the sea along the northeast and north margins of the 1883 debris-avalanche deposit. At least three flows reached the sea on the northeast in late March (Swanson and Kienle, 1988). These deposits are 1-3 m thick, lobate, rich in pumice, and contain breadcrust bombs. Upslope, they are overlapped by a late-April to lateAugust sequence of less extensive lithic (dome rock) pyroclastic flows.

These voluminous flows, like the similar underlying ones of 1976, further infilled a broad low that had existed between 


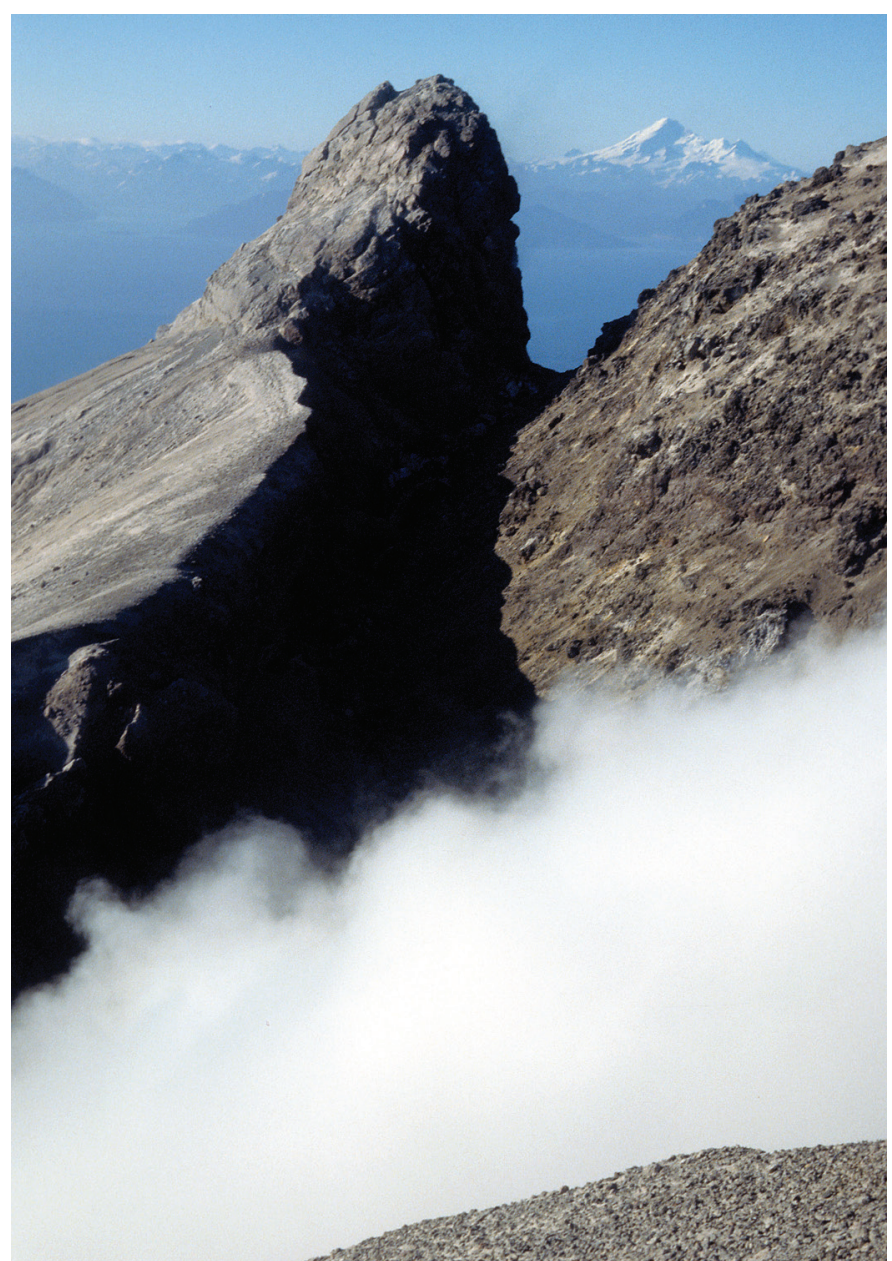

Figure 51. View north-northeast of Augustine's 1935 (left) and 1986 domes, from 1964 dome (foreground). lliamna volcano in distance. (USGS photograph by R.B. Waitt, 9 July 1989.)

an old sea cliff and the mass of 1883 debris-avalanche hummocks.

\section{Pumiceous Flows}

Some 1986 pumiceous pyroclasic flows (unit 86p, plate 1) on the north flank reached the sea, but others stopped well short of the coast with steep margins 1 to $3 \mathrm{~m}$ high and unchanneled surfaces. These discrete flow fronts show that the pumiceous pyroclastic flows numbered at least several. Pumice clasts, including some to $1 \mathrm{~m}$ and smaller breadcrust clasts, concentrate around flow margins and at the surface. At depth they are sparse. Burned small logs also mark the termini of a few lobes on the north. The flow matrix is brownish granular medium sand, poorly sorted. Even the pumiceous flows contain in distal reaches lithic clasts as large as $1.5 \mathrm{~m}$; where swept from adjacent 1883 debris-avalanche hummocks the clasts are as large as $3 \mathrm{~m}$. A few such clasts from these hummocks are hydrothermally altered andesite. Along the back of Northeast Beach (fig. $2 B$ ) where storm waves have cut into the 1986 pyroclastic-flow deposit, the deposit is punctured by vertical fines-free gas-escape pipes. Atop these deposits incorporated tree trunks and branches $15 \mathrm{~cm}$ through are heavily charred, many of them entirely (contrast with twigs atop "hybrid flows" below). Between Rocky Point and west of Grouse Point, several 1986 pumiceous pyroclastic flows and lahars reached the sea or nearly did, overlapping and veneering similarly distributed 1976 pumiceous deposits.

\section{Lithic Pyroclastic Flows}

While the dome was growing during the latter part of the 1986 eruption, parts it repeatedly collapsed to form smallvolume pyroclastic flows of porphyritic andesite (dome rock), including blocks as large as 3 to $4 \mathrm{~m}$, some of them compositionally banded as Johnston (1978) described of the similar 1976 deposits. Lateral levees of some individual flows are 1 to $3 \mathrm{~m}$ high and traceable hundreds of meters upslope. Some lithic flows contain as much as 20 percent surface pumice. A few of these flows were filmed in progress by Maurice Krafft

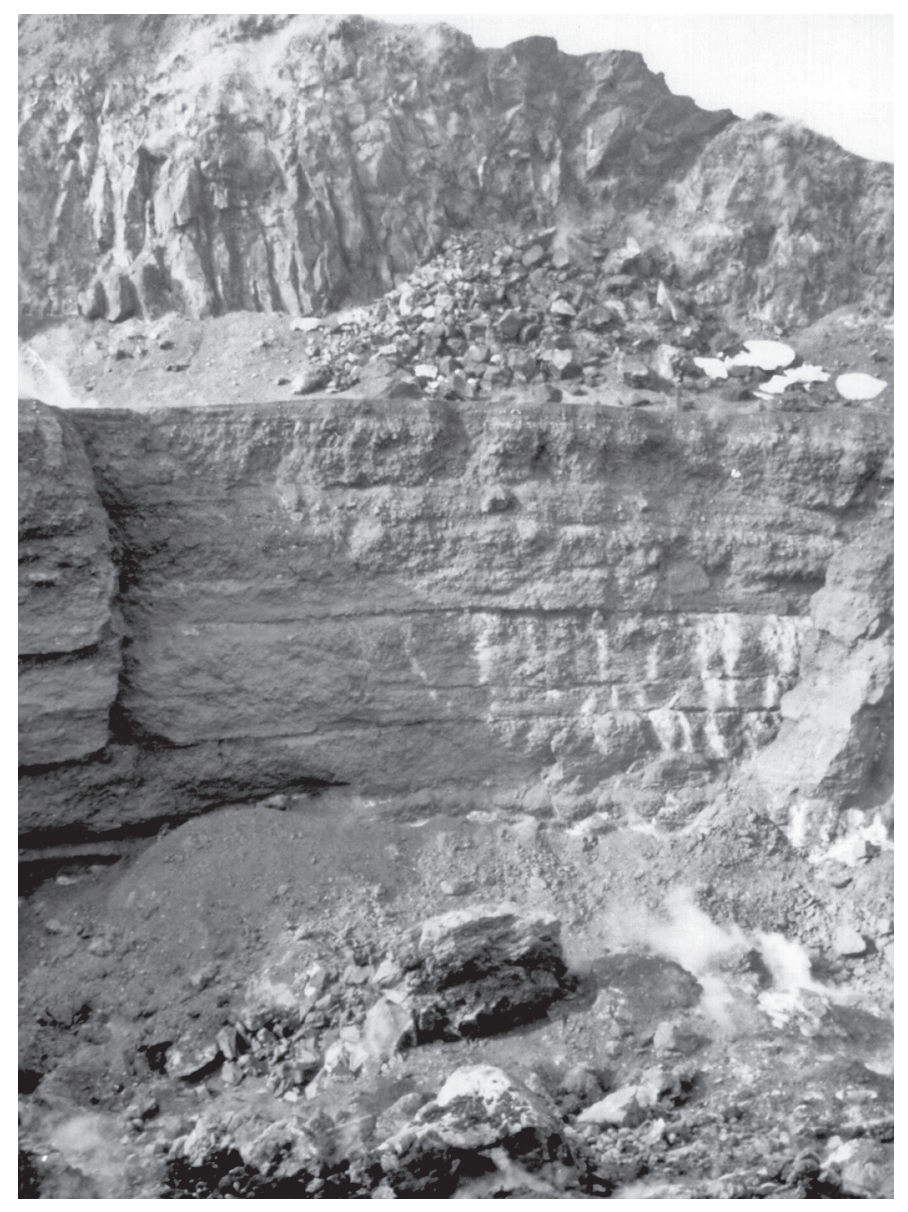

Figure 52. Lithic-fall beds at summit domes of Augustine Volcano that bury the former rough-surfaced crescent of the 1976 dome. View south from 1986 dome showing bedded debris shed and thrown by growing 1986 dome. Background, composite summit dome capped by 1964 dome. (Photograph by Jürgen Kienle, 1 July 1988.) 


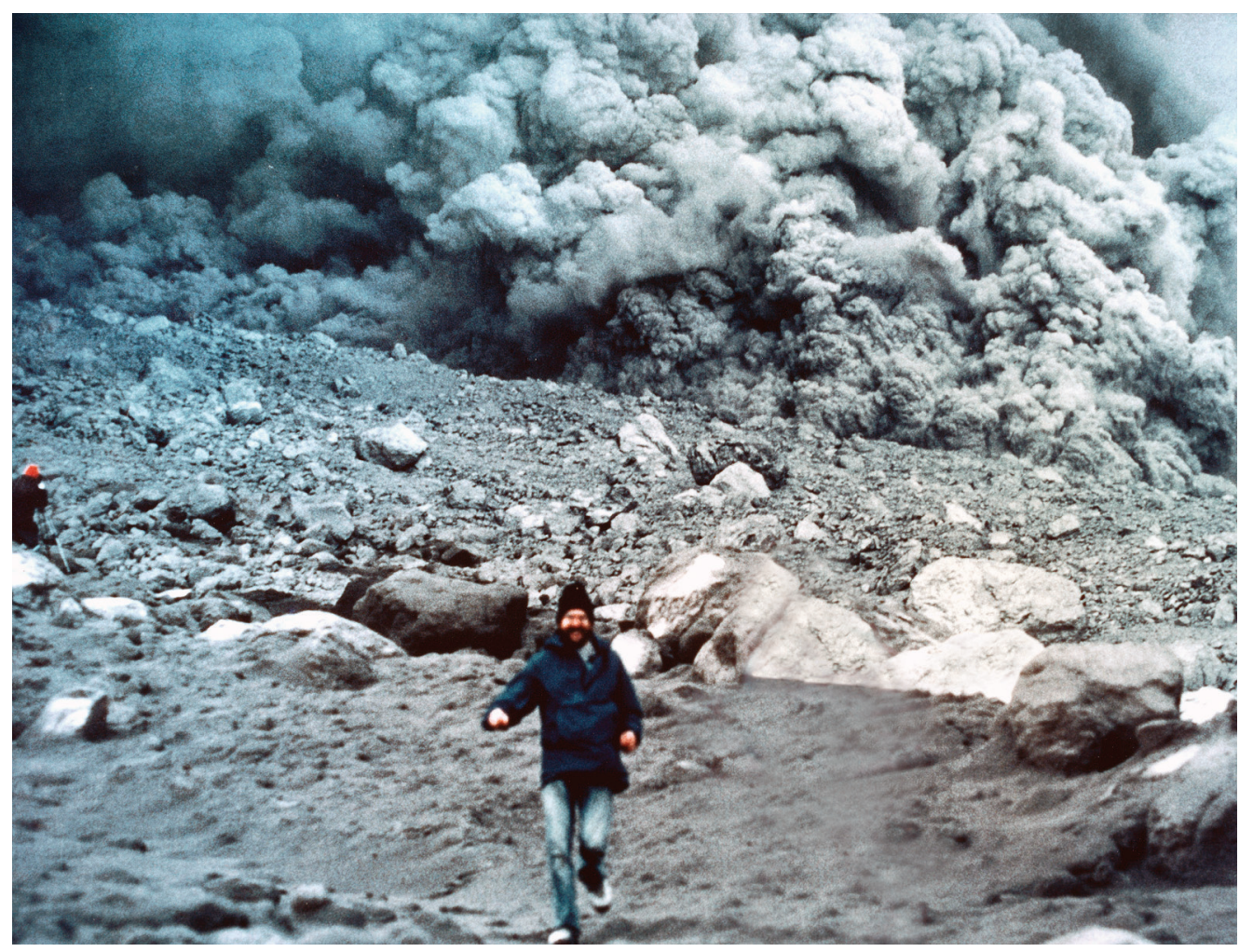

Figure 53. View southwest of moving 1986 pyroclastic flow that issued from collapsing lava dome (out of view upslope left) flowing down lower Augustine's north flank near Burr Point. Center figure is Jürgen Kienle. On left Maurice Krafft films the show. (Photograph by Katia Krafft, 29 August 1986.) The Kraffts-French volcanologists, husband and wife-died in a fierce fiery flow of this type that swept off Fugendake (Unzen) volcano, Japan, on 3 June 1991.

(fig. 53) and may be seen in the IAVCEI volcanic-hazards video (Krafft, 1991). These numerous flow deposits (unit 86I, plate 1) constitute a broad fan leading down from the 1986 dome. This fan buries most of a similar 1976 fan.

\section{Hybrid Flows and Lahars}

Along a lower north-flank swale (4.8 to $5.2 \mathrm{~km}$ north of Augustine's summit on azimuth 004), a March 1986 pumiceous pyroclastic-flow deposit merges downslope into an area where an underlying 1976 pumiceous flow deposit is beveled and channeled 1 to $3 \mathrm{~m}$ deep. Numerous large lithic boulders are stranded or stacked against each other, in places small boulders stacked upslope of a large one (fig. 54). The surface is clearly water scoured, and the deposit is winnowed, matrix-free large boulders and boulder gravel. The lack of matrix between and atop boulders contrasts with recent laharic deposits that include abundant sand and fine-gravel matrix - at Mount St. Helens (1980-86) in Washington, and at Redoubt volcano (1990) and Mount Spurr (1992) in Alaska (Waitt and others, 1983; Pierson and Janda, 1994; Waitt and others, 1994; Waitt, 1995; Pierson and Waitt, 1999). Thus some early pumiceous pyroclastic flows at Augustine in 1986 must have swiftly melted snow to transform into water-rich floods. These floods scoured the 1976 deposits and left small bars of gravel and lags of boulders. One of these 1986 scour-and-bar areas is overlapped from upslope by a pumiceous steep-margined pyroclastic-flow deposit. And so these slightly younger 1986 pumiceous flows, sweeping mainly over recently emplaced pyroclastic-flow deposit, could not entrain and melt much snow or cause floods. All these deposits are lumped with unit 86p (plate 1).

On the east side of the north-flank swale, an extensive early 1986 pumiceous flow that nearly reached the sea has properties hybrid between pumiceous pyroclastic flow and pumiceous lahar. This pumiceous flow (also mapped with unit $86 p)$ has only centimeters-high margins, low surface slope and relief. Discontinuous narrow and shallow channels decorate its surface, on which perch delicate willow twigs charred only at their resting points. Several broad areas are marked by many shallow but wide explosion pits and (or) collapse topography. At the center of many of these pits, only 0.3 to $1 \mathrm{~m}$ deep, lie openwork cobbles, apparently the tops of (rootless) fumarolic pipes. Some of these pits are surrounded by a small rim of ejected ash. Some of them align north-south along an infilled gully. In one sharp gully the pumice is concentrated in small waterlaid bars. Such features show that this pyroclastic flow 
was relatively thin and cool yet highly mobile, that it collapsed and vented by melting of underlying snow, and that free surface water locally rilled and redeposited it. This flow deposit terminates atop one of the flood-scoured surfaces described just above. Thus the hybrid flow followed and was separate from the water flood.

Pyroclastic flows in 1986 also melted snow on other flanks of the volcano. Small-volume pumiceous pyroclastic flows, some grading into lahars, descended gullies on the northwest and east flanks. Distinguishing the deposit of small pyroclastic flows from hybrid flows from lahars is difficult. Thus these deposits also are mapped with unit $86 p$.

\section{Occasional Small Events}

Besides the definite historical eruptions since 1812, several brief, small events have been reported in newspapers or occasional notes (Becker, 1898; The Alaskan (newspaper) 21 June 1902; The Seward Daily Gateway (newspaper) v. 4, no. 1, 1908; Cordeiro, 1910; Russell, 1910). None of them suffice to qualify as a separate eruption. Several minor events were reported in the 15 years after the 1883 eruption. Thus in 1885 "steam from shore to summit" was a likely symptom of rain or snowmelt infiltrating still-hot 1883 pyroclastic-flow deposits that covered the north-northeast flank. And "smoke" or "steam" from the summit in 1893 and 1895 were likely lingering effects of the still-hot 1883 dome within the summit crater. This is especially clear in Becker's (1898) brief remarks of his 1895 climb to the dome. In 1902 there may have been a small summit intrusion into the 1883 dome, for increased fumarolic exhalations inspired a report of unusual levels of "smoke and steam for several months." A minor burst of molten lava occurred in March 1908.

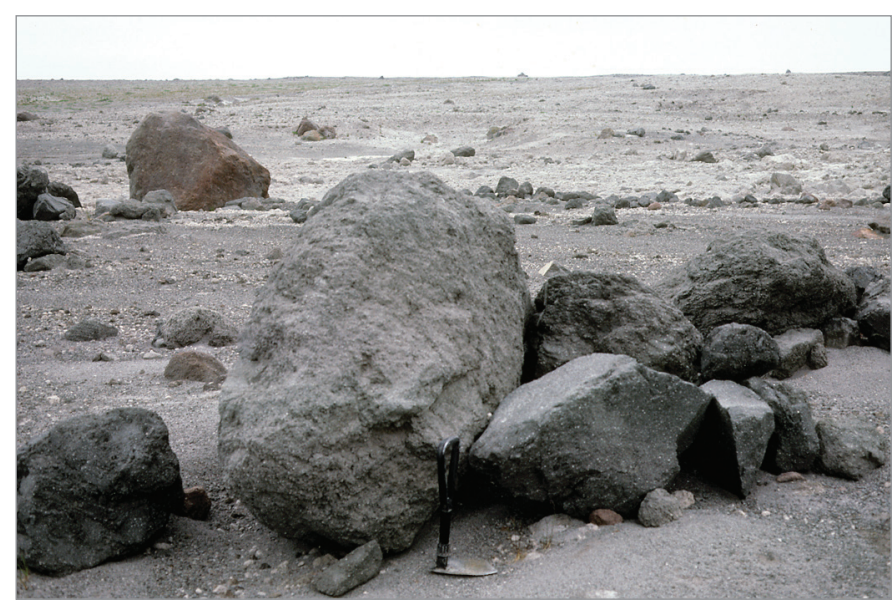

Figure 54. View east on lower north flank of Augustine Island showing imbricated boulders stacked by 1986 flood. Lack of sandy matrix indicates flow was water flood rather than debris flow (compare Waitt, 2002, fig. 10). USGS photograph by R.B. Waitt, 23 June 1988.)

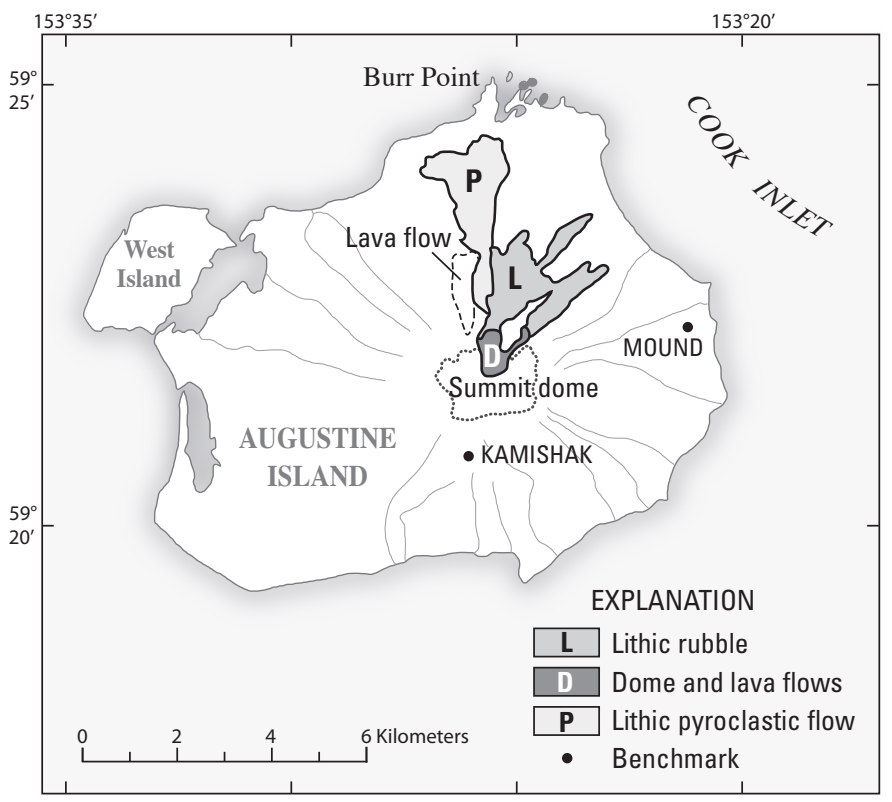

Figure 55. Sketch map of largest deposits of the January-April 2006 eruption of Augustine Volcano. P, pyroclastic flow of dense pumice on 28 January 2006 that filled former shallow pond at lower west edge of 1986 pumiceous pyroclastic flows (plate 1); $D$, new dome and short, steep lava flows from it; $L$, lithic coarserubble flows that cascaded from growing dome and lava-flow fronts. Highly simplified from map compiled by Michelle Coombs. Our plate 1 no longer accurately portrays either surface deposits or topography in these now-buried areas. See provisional map detailing all 2006 deposits by Michelle Coombs in Power and others (2006).

In September-October 1971 billowing fumaroles and a report of incandescence followed an earthquake swarm within the volcanic cone in late August and early September (Kienle and Swanson, 1980, 1985, p. 25-28). And after the 1986 eruption, a minor burst may have occurred in July 1988. On 10 July 1998 part of the still-warm 1986 dome spine collapsed, melted snow below, and formed small mudflows one of which reached the sea (McGimsey and others, 2003).

None of these events were closely observed nor individually lasted long. They are likely persisting effects (in 1885-95 and 1988-98) of an earlier eruption, or (in 1971) a failed eruption yet gaseous herald to the next one. They are analogous to closely monitored behavior at Mount St. Helens after the intermittent dome-building eruptions for six years after the explosive 1980 eruptions. The last gaseous dome eruption came in May 1985 and then small gas-poor dome eruptions in May and October 1986. Between December 1989 and February 1992 came at least 17 small but spectacular gas bursts from the still-hot dome, several of them spewing ballistics and small lithic flows out $1 / 2$ kilometer or so, but no new magma came to the surface (USGS, Mount St. Helens monthly reports [unpublished]). The next true eruption of Mount St. Helens began in late September 2004 (Dzurisin and others, 2005). 
Augustine's occasional small events probably reflect similar behavior in the wake of significant eruptions. After 1986, Augustine's next true eruption began in January 2006.

\section{Eruption}

Small earthquakes increased beneath Augustine Volcano through fall 2005, and by mid-December the moat south of the 1986 dome and a fumarole on the upper south flank steamed heavily. From 11 to 17 January 2006 several explosions burst from the moat just south of the 1986 dome. The largest spewed small flows onto the snowclad upper flanks to several azimuths (Power and others, 2006). On 28 January 2006 the largest pyroclastic flow, of dense pumice, swept down down to the lower north flank to the west edge of the 1986 pyroclastic fan and filled the shallow pond there. The flow was hot: as in the previous two eruptions, clouds rolling beyond the flow's edge burned off surrounding scrub alder. In winter 2006, a dome grew at the summit, filling the subsummit moat north of the 1986 dome and covering that dome and draping new stiff lava flows down the upper north and northeast flank. These and small lithic pyroclastic flows spalling from the lava flows expanded until the end of March 2006.

The 2006 pyroclastic flows and lahars were far less extensive than during the previous three eruptions. Mapping the new deposits is beyond the scope of this report that was essentially complete, edited, and revised by fall 2003. Our topographic and geologic map (plate 1) remains as earlier plotted. On this map, geographic details such as of the summit and of the north-flank pond are as they existed before the 2006 eruption. A small figure generally outlines deposits on the north flank large enough to be future map units (fig. 55). In these areas our map (plate 1) shows surface deposits that have since been more or less buried by 2006 materials. For details and more accurate outlines of all 2006 deposits, see map compiled by Michelle Coombs (Power and others, 2006, fig. 2).

\section{Nonvolcanic Deposits}

\section{Talus and Stream Deposits}

Once emplaced, volcanic domes cool from the outside, leaving abundant very angular fragments of all caliber on their steep sides. Especially during thaw and snowmelt in late spring to midsummer, this material frequently spalls and cascades. And so a talus apron formed around the steep base of the 1986 dome, lapping downslope onto the top of the 1986 pyroclastic fan. The material is trifling in volume, is lithologically identical to the dome-collapse debris during eruption, and cannot be distinguished on plate 1. Sometimes a relatively large collapse occurs, for instance a piece of the 1986 dome spine fell on 12 July 1998. As of summer 2003 the 1986 dome spine remained warm, fumaroles steaming at its base. In descending the head of the 1986 fan, collapsing dome debris sometimes melts some snowpack there to form a small debris-and-water flow down the lower northeast flank. From the newly hot 2006 dome and its steep lava flows, such processes are likely to continue for years.

Most gullies on Augustine contain small streams that flow especially during snowmelt April to July. All but a few like southside Augustine Creek dry up by midsummer. Each season these streams rework eruptive material and deliver some of it to the coast, expanding small fans seaward that are then attacked and beaten back by sea waves. These streamcourse tracks are too narrow to distinguish at 1:25,000 scale on plate 1 .

\section{Eolian Deposits}

At the back of most sandy beaches exposed directly to the sea and above high-tide level are one or more coastwise ridges of loose, well-sorted medium sand, material wind-winnowed from the adjacent beach. These eolian deposits (unit e, plate 1) ranges from a discontinuous skim only a few decimeters thick to ridges a kilometer and more long and as high as $8 \mathrm{~m}$.

Where the seaward side of a tall dune is opened by storm waves, internal stratigraphy shows several strata emplaced over decades and centuries - made clear by interbeds 1 to $5 \mathrm{~cm}$ thick of ash or peat. Thus at Rocky Point (second youngest debris-avalanche deposit) a 113-cm section in back-beach dune sand lies atop rounded beach cobbles that in turn overlie the wave-beveled top of Rocky Point diamict. The eolian wellsorted medium sand is interrupted by at least seven gray-sand ash layers, three peaty layers, and near section's top the unmistakable Katmai 1912 white-silt ash.

On the southwest coast a dune ridge $8 \mathrm{~m}$ high exposes tephra $\mathrm{M}\left(750{ }^{14} \mathrm{C}\right.$ yr B.P.) at depth $4 \mathrm{~m}$ (section RBW 91A.138, plate 2). But generally the capping veneer of eolian sand thickens gradually inland from the southwest coast from a few centimeters to a meter and more atop older and older beach ridges. Atop the oldest mapped band (unit bedo, plate 1) a pit excavated down into eolian sand reveals tephra $B$ at depth $80 \mathrm{~cm}$, that underlain by a lithic ash, and beneath which is peat yielding a radiocarbon age of $400 \pm 50 \mathrm{yrs} \mathrm{BP}$ (table 2) (sections RBW 92A.26 and 27, plate 2).

And so the lower, older parts of many eolian deposits are clearly prehistoric, but except atop the broad southwest beach ridges (units bed) they are far too small and spottily exposed to distinguish cartographically.

\section{Beach Deposits}

The coast of Augustine Island is a nearly continuous beach ranging from bouldery headlands to sandy coves to a long sand spit on the southwest part of the island. The geologic map (plate 1) classifies beaches as either rocky or sandy. At and above the level of beach deposits at the back of many beaches are jams of logs and diverse manmade flotsam. In exposed reaches (northeast, east, southeast) storm surf has thrust flotsam as much as $2 \mathrm{~m}$ above spring-high tide. 
The rocky beach deposits (unit br, plate 1) consist mostly of cobbles to boulders. Some boulders are as large as $7 \mathrm{~m}$, a lag winnowed from adjacent bluffs of debris-avalanche deposit. But generally the beach stones are $1 / 4$ to $2 \mathrm{~m}$ in intermediate diameter, most of them submerged at high tide. Almost all gravel clasts are of porphyritic andesite and subordinate pumice, but southside beaches also have sandstone and shale fragments derived from the nearby Jurassic Naknek Formation. Because the boulders and in many places stranded large logs defend the sea cliffs against normal waves, erosion of the cliffs and new contributions to the beaches occur mainly during exceptional winter storms.

Exotic pebbles (granite, granodiorite, quartz diorite, gabbro, porphyritic dikerocks, hornfels, quartzite, argillite, gneiss, greenstone, vein quartz) are a minor component of fine gravel on south beaches downslope from Pleistocene drift. Some small exotic stones derive from conglomerate beds within Jurassic sandstone. Exotic pebbles lie more sparsely on beaches on the east, north, and west sides of the island, though only on the south lies an apparent upslope source. The exotic pebbles must derive from glacial drift that formerly blanketed all slopes of the volcano. Most of this material has been brought down to the shore in Holocene debris avalanches, and then over time winnowed out by waves.

The sandy beach deposits (unit bs, plate 1) are loose medium sand to pebbly sand, locally pebble and cobble gravel. In many places the sandy deposits surround numerous large boulders, a lag deposit from storm waves over time attacking debris-avalanche, pyroclastic-flow, and laharic deposits. Most beach faces slope less than $10^{\circ}$. But where 1986 pyroclastic flows are being rapidly eroded back and the local supply of sand large as at Northeast beach, the material is very coarse sand to granule gravel and beach faces reach 12 to $14^{\circ}$. Those like Northeast Beach most exposed to storm waves vary in width and steepness from time to time.

\section{Tidal-Flat Deposits and Marsh Deposits}

Extensive low-lying irregular flats of muddy sand in areas open to tidal inundation but protected from coastal surf are floored by gravelly muddy sand (unit t, plate 1) that overlies debris-avalanche and other coarse deposits especially on Augustine's west and north shores. Most of these deposits have been very gradually winnowed by fairly gentle currents and waves - probably especially storm waves during springhigh tides - from adjacent debris-avalanche hummocks and pyroclastic-flow deposits.

Among these deposits are pancake-like slabs as large as $4 \mathrm{~m}$ diameter and $30 \mathrm{~cm}$ thick of gravelly sand that sporadically overlie even last-season's marsh grasses and sedges. These odd bodies can only have been imported by winter's shorefast neap-tide ice that higher spring tides later float and raft inland.

Gravelly muddy sand also underlies several freshwater marshy areas back from the shoreline, the largest near southeast coast (unit am).

\section{Comparison to Previous Geologic Map}

This geologic map of Augustine Island (plate 1) — supported by stratigraphy, chronology, geomorphology, and field sedimentology - differs from the previous geologic map (Detterman, 1973). That map depicts most surficial deposits, except for the clearly late historical, as "Pleistocene" or "Pleistocene and Holocene" in age. Our new map and report show that all but a few inliers are late Holocene, younger than about 2,200 radiocarbon years. The 1973 map also labels extensive areas on east, south, and northwest coasts as in-situ "lava flows;" our descriptions and map show these to be instead large-bouldery debris-avalanche deposits. The one clear lava flow on Augustine Island - North Slope lava flow_-the 1973 map calls "volcanic mud."

The largest changes in implied processes are the number and extent of the newly mapped hummocky boulder diamicts that we infer to be deposits of catastrophic debris avalanches from the summit. By stratigraphy and geomorphology, at least 12 late-Holocene debris-avalanche deposits are discernible. The youngest three lie on north coast: Rocky Point is of moderate volume, Burr Point and especially West Island rather large.

All the large debris-avalanche deposits identified on Augustine Island lie at the present coast and most of them extend seaward some distance, perhaps kilometers according to hummocky topography shown on bathymetric charts. The older avalanche deposits have been wave eroded back hundreds of meters into tall sea cliffs.

\section{Précis of Eruptions}

Augustine began erupting during the late Pleistocene. Late Wisconsin ( $>20,000$ to 15,000 years ago) glacial debris directly overlie Mesozoic rocks (Johnston, 1979). But two of our radiocarbon dates older than 39,000 years (table 2) suggest that some of Augustine's obscure glacial history predates the late Wisconsin.

Several south-flank exposures reveal a sporadic history from the Late Wisconsin to the late Holocene (2,500 B.P.), occasional explosive eruptions of pumiceous flows and coarse pumiceous tephra. Through the late Holocene from 2,200 to 390 B.P., six eruptions deposited coarse-pumice tephra, averaging one every 300 to 360 years.

Whether most of debris avalanches occurred during or between eruptions is unclear. Most stratigraphy of the coarse prehistoric tephras lies in spots away from a contemporaneous debris avalanche. Yet tephra G overlies nearly directly the uppermost of the East Point avalanches, tephra $\mathrm{C}$ immediately overlies the South Point avalanche, and tephra I overlies Southeast Point avalanche (fig. 22).

The seven historical eruptions between 1812 and 2006 have yielded no tephra bed comparable to the six thick and coarse prehistoric ones. Yet on Augustine's north flank, the 
1976 and 1986 eruptions built pumiceous-flow fans as thick as some of those in prehistoric eruptions on other flanks.

\section{High-Energy Flows From Insular Setting}

\section{Pyroclastic Density Currents}

Hot pyroclastic density currents (pyroclastic flows and pyroclastic surges) move at speeds generally between 10 and $50 \mathrm{~m} / \mathrm{s}$ but sometimes exceed $100 \mathrm{~m} / \mathrm{s}$. Krafft (1991) shows images of moving pyroclastic flows, some from Augustine (fig. 53). Pyroclastic surges can move across water. During the 1883 Krakatau eruption in Indonesia, large hot pyroclastic surges moved as far as $80 \mathrm{~km}$ across the sea to coastal Sumatra (Verbeek in Simkin and Fiske, 1983; Sigurdsson and others, 1991; Carey and others, 1996). Smaller pyroclastic surges moved several kilometers across water during the eruptions in 1902 at Mont Pelée in Martinique and of La Soufrière in St. Vincent, and in 1911 and 1965 at Taäl in the Philippines (Anderson and Flett, 1903; Moore and others, 1966; Bullard, 1976; Blong, 1984; Scarth, 2002). A much-shown video of a 1997 eruption of Montserrat, West Indies, shows a pyroclastic flow or surge moving vigorously from the coast $2 \mathrm{~km}$ out across the sea surface.

Such a flow beyond the present coast is possible from Augustine Volcano, whose numerous eruptions in the past 2,500 years have included pyroclastic flows and surges. Thick pyroclastic-flow deposits about 1,100 years old extend to the coast on the southwest and south-southeast, 4 to $7 \mathrm{~km}$ from the summit (plate 1), now eroded back into sea cliffs. Pyroclasticflow and -surge deposits of the 1883, 1976, and 1986 eruptions on the north volcano flank extend to the coast $5.7 \mathrm{~km}$ from the summit.

\section{Debris Avalanche and Surge ("Blast")}

\author{
The landing upon this island was effected with \\ some difficulty on the ebbing tide, in consequence of \\ the shore being bounded at the distance of a quarter \\ of a mile by innumerable large detached rocks, \\ through which a passage was found with much labor \\ for the boat. Fragments of [such] rock... appeared \\ to lie off most parts of the island, but no where at so \\ great a distance as from its northern shore. \\ -Peter Puget, Chatham, May 2, 1794 (Vancouver's \\ "Voyage of Discovery") (Lamb, 1984)
}

\section{Augustine's Debris Avalanches}

Augustine has shed far more coarse, hummocky avalanches in late Holocene time than have been reported from any other of the world's volcanoes. Augustine's abundant coastal hummocky, boulder diamicts originated by debris avalanche from the summit-dome complex (table 3, plate 1). These deposits lie at nearly all azimuths, seaward from which are wave-winnowed lags of huge boulders exposed at low tide, like those on the north-northwest that encumbered Puget's 1794 landing.

The volumes of most Augustine debris avalanches are difficult to measure because of uncertainties in their extent offshore and especially in mean thickness. Siebert and others (1995, p. 387 and fig. 18) estimate that bulk volume of Augustine's debris avalanches would be no larger than about $0.5 \mathrm{~km}^{3}$, judged from an empirical relation among eight volcanoes that debris avalanches tend to be no larger than about 10 percent the volume of a cone. The Burr Point avalanche deposit is about $1,800 \mathrm{~m}$ wide and 3,500 to 4,000 $\mathrm{m}$ long. Its thickness at the former coast is $70 \mathrm{~m}$ and less. If its average thickness is $40 \mathrm{~m}$, bulk volume of the Burr Point debris avalanche beyond the former coast is 0.25 to $0.3 \mathrm{~km}^{3}$. The avalanche that formed West Island some 350 years ago is about 2,900 $\mathrm{m}$ wide and 4,100 $\mathrm{m}$ long beyond the former coast. If its average thickness is $40 \mathrm{~m}$, the volume of the West Island avalanche deposit lying beyond the former coast is about $0.5 \mathrm{~km}^{3}$. Thus a typical large avalanche might be 0.3 to $0.4 \mathrm{~km}^{3}$, the largest perhaps 0.5 to $0.6 \mathrm{~km}^{3}$.

Most of the Burr Point avalanche deposit, perhaps 0.25 $\mathrm{km}^{3}$, lies beyond a preexisting sea cliff (plate 1) marking the former coast, conspicuous on aerial photographs before the 1976 and 1986 eruptions (fig. 42). The part of West Island debris avalanche beyond that former coast is perhaps $0.4 \mathrm{~km}^{3}$ or more, $1 \frac{1}{2}$ to 2 times the volume of the Burr Point debris avalanche. And most of West Island avalanche rode far seaward of the cliff, indicating its higher speed. The southsouthwestmost hummocks of West Island are planed off 3 to $12 \mathrm{~m}$ above highest spring-tide level and capped by a lag of huge boulders (figs. 37, 38), some of the mounds separated from each other by scabland-like gashes. These effects seem to record a great wave that swept over this area, removing the fines and cutting the gashes - probably the seawater being displaced as the avalanche surged into and beneath it.

The dimensions and volumes of the many older debrisavalanche deposits are more speculative. At least five of them are $4 \mathrm{~km}$ or so wide at the coast (plate 1). At least two of them overrode sea cliffs and ran seaward. All these coarse deposits are themselves now eroded back hundreds of meters into tall sea cliffs. Submarine hummocky topography extending far offshore (fig. 11) indicates at least some of the thick deposits of the east-coastal cliffs had plowed $4 \mathrm{~km}$ through seawater. Off Augustine's other coasts such submarine hummocky topography extends 1 to $3 \mathrm{~km}$. Thus several of the older debris-avalanche deposits must have been as large as the Burr Point or West Island avalanches.

A fissure-riddled moving landslide removing a volcano's summit will suddenly depressurize below it any intruding magma body and the surrounding hot groundwater system. These can explode as at Mount St. Helens in May 1980. This ejected gas-rock mixture collapses into a gravitational groundhugging swift-flowing pyroclastic surge - at Mount St. Helens 
it swept as far as $25 \mathrm{~km}$ across the surrounding landscape (Waitt, 1981; Moore and Sisson, 1981; Druitt, 1992). The 1956 landslide off Bezymianny in Kamchatka also released such a lateral hot surge (so-called "blast") (Gorshkov, 1959; Bogoyavlenskaya, 1962); the 1888 landslide off Bandai-san in Japan may have. Of the 12 eruptions of Augustine in the last 2,200 years or so that include a debris avalanche, only one (West Island, about 370 yr B.P.) shows evidence of an attending ground surge (figs. 9A, 35).

Debris avalanches are rare events in the history of any volcano. Augustine has many ordinary eruptions between those that slough a large avalanche. Only one of seven historical eruptions of Augustine included a debris avalanche (fig. 9B). Attendant lateral surges ("blasts") are rarer yet.

\section{Mobility and Speed of Volcanic Debris Avalanches}

Large debris avalanches, whether from volcanic or alpine sources, are much noted for their huge runouts from sourceHsü (1975) called it "excessive travel distance." Compilations by Siebert and others (1987; 1995, fig. 17) on dozens of volcanic debris avalanches show that the ratio of maximum vertical fall to maximum horizontal runout $(H / L$ ratio) of avalanches smaller than $1 \mathrm{~km}^{3}$ ranges from 0.09 to 0.18 with a mean at 0.13 (fig. 56). That is, the toe of a debris avalanche typically flows downvalley five to ten times the height lost. At Augustine Island, even the steepest bounding $H / L$ ratio 0.18 puts an avalanche at the coast, and at most azimuths 1 to $3 \mathrm{~km}$ beyond (fig. 11). All of the 11 largest debris-avalanche deposits mapped at Augustine (plate 1) extend beyond the coast, those older than a millennium having been wave eroded far back into sea cliffs. Because in the past 750 years deposits have been most voluminous on the north and west flanks,

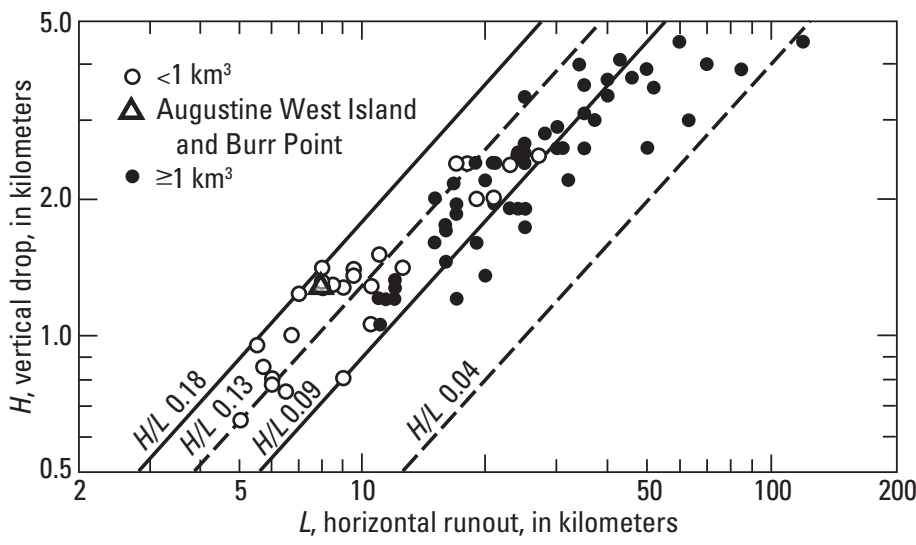

Figure 56. Plot of fall $(H)$ versus runout $(L)$ for volcanic debris avalanches (circles) from around the world (Siebert and others, 1995, fig. 17). Augustine's West Island avalanche $(H / L=0.148)$ and Burr Point avalanche $(H / L=0.157)$ plot above (are less mobile than) average $H / L=0.13$ for their volume class $\left(0.1-1.0 \mathrm{~km}^{3}\right)$. those coasts are built out farther from the summit than are the island's wave-receded east and south coasts.

The mean and limiting $H / L$ ratios for data of debris avalanches of volumes 0.1 to $1.0 \mathrm{~km}^{3}$ plotted on figure 56 show that the limits of Augustine's avalanches indicated by bathymetry are somewhat short of the mean runout for avalanches less than $1 \mathrm{~km}^{3}$ in volume. But this relation is logical: Augustine's avalanches should decelerate when the bulk density of the surrounding medium being displaced jumps three orders of magnitude - from air to water - as an avalanche sweeps into the sea.

Several of the hummocks about Burr Point draped by great slabs of mud containing marine shells (fig. 44) shows that the 1883 avalanche entered the sea swiftly and violently. But just how fast might this and older debris avalanches have been flowing when they struck the sea?

In an early simulation of the Mount St. Helens debris avalanche, Voight and others (1983) suggest speeds of 60 to $80 \mathrm{~m} / \mathrm{s}$ at the base of the cone; a more recent simulation suggests speeds as high as 100 to $110 \mathrm{~m} / \mathrm{s}$ (Sousa and Voight, 1995, fig. 10). Dynamic simulations of two debris avalanches in Japan by Ui and others (1986) indicate speeds as high as 100 to $150 \mathrm{~m} / \mathrm{s}$ at the bases of volcanic cones. A dynamic simulation for Augustine's 1883 avalanche suggests speeds exceeding $100 \mathrm{~m} / \mathrm{s}$ at the coast (Siebert and others, 1989, table 4). But are such high speeds "reasonable" for an Augustine debris avalanche at the seacoast?

A few North American debris avalanches have a simple geographic means for estimating speed. Where an avalanche runs up onto an opposite valley side and converts its kinetic energy to altitudinal energy, one measure of its velocity just before runup is the conservation-of-energy relation $v=\sqrt{2 g h}$, where $v$ is velocity of flow, $g$ is gravitational acceleration, and $h$ is height or runup.

At a distance of $7.3 \mathrm{~km}$ from the former summit of Mount St. Helens, a toe of the 1980 debris avalanche, having crossed a valley floor, rode $390 \mathrm{~m}$ up over ridgecrests (fig. 57A). If this debris were flowing entirely by its own momentum, a frictionless flow converting kinetic energy to altitudinal energy would be moving at least $87 \mathrm{~m} / \mathrm{s}$ to achieve this runup. A small tongue of this flow struck Spirit Lake at a distance of $8.6 \mathrm{~km}$ from the summit. It entered the lake with enough speed and volume to raise a tsunami wave as high as $275 \mathrm{~m}$ on opposite shores (Waitt and Pierson, 1994).

From Plinth Peak at Mount Meager volcano in British Columbia near the end of an eruption about 2,400 years ago (Stasiuk and others, 1996), a landslide slid into and across the Lillooet valley and ran up as much as $458 \mathrm{~m}$ on the opposite side (fig. 57B) (Evans, 1992; R.B. Waitt and C.J. Hickson, 1996, unpub. data). By the energy equation above, a frictionless flow entirely under its own momentum needs a velocity as high as $95 \mathrm{~m} / \mathrm{s}$ to achieve this runup. An older landslide ran as high as 503 m up the open Salal Creek valley; by the same calculation, it needs a velocity of $99 \mathrm{~m} / \mathrm{s}$. Actual velocities would be higher, for the calculation ignores energy (thus velocity) lost to friction during the runup. 

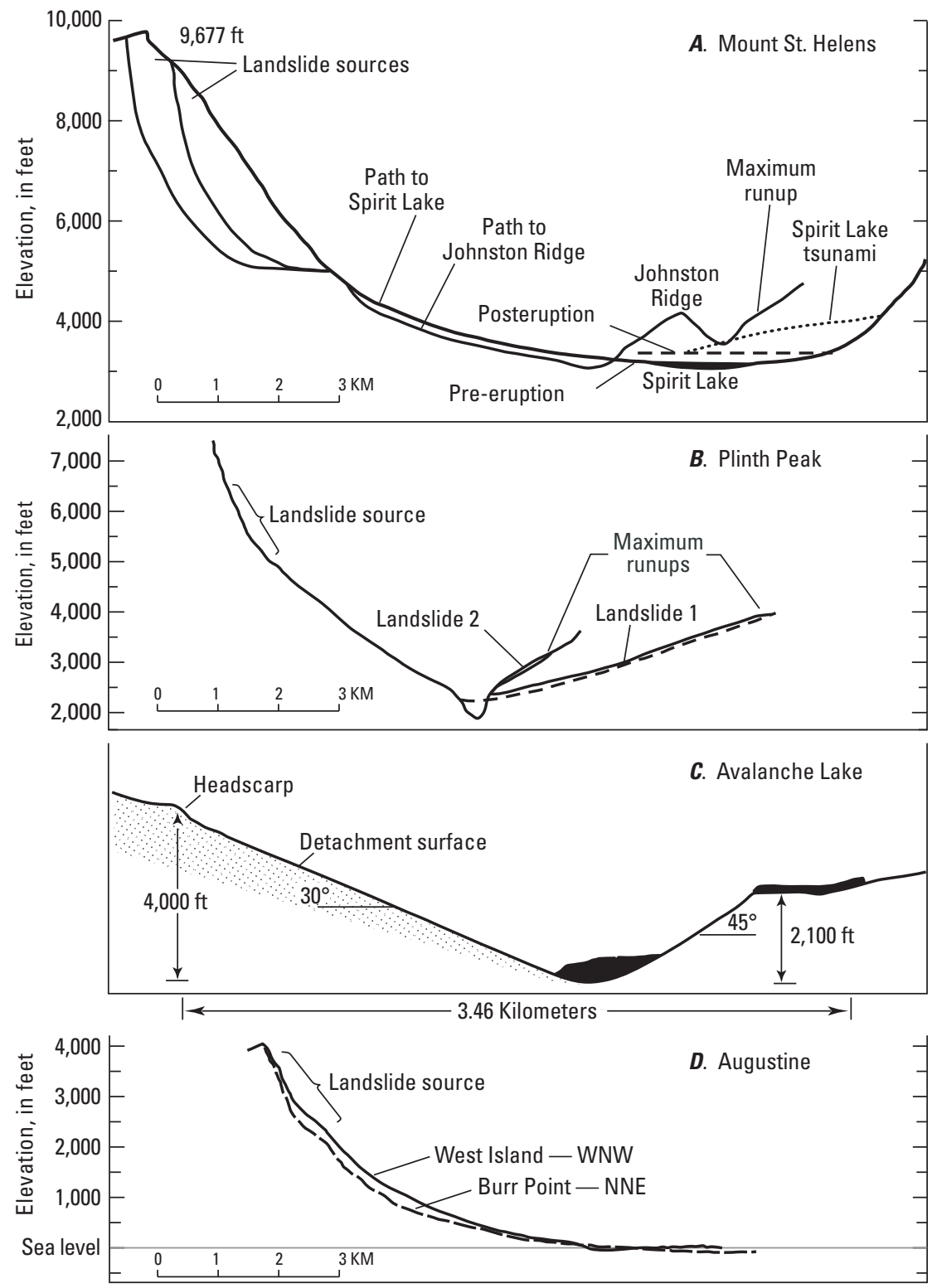

Figure 57. Profiles $(A, B, C)$ of large landslides from whose runup heights the "minimum" velocity (excluding friction) at start of runup is calculated [in square brackets below] by simple conservationof-energy relation of Chow (1959). These values, which do not consider longitudinal forces, are almost surely too high (see text). $D$, Profiles of two of Augustine's youngest debris avalanches. For $B$ and $C$, run-down altitude and volumes of landslides (debris avalanches) are comparable to $D$. Rundown altitude and avalanche volume of $A$ much exceed Augustine's. $A$, Two profiles of Mount St. Helens, Washington, 18 May 1980 landslide paths - to South Coldwater Creek runup $(311 \mathrm{~km} / \mathrm{hr}$ ) and into Spirit Lake (dashed line tsunami). $B$, Profile of two Plinth Peak avalanches near Mt. Meager, British Columbia: (II) is about 2,360 yr B.P. $(342 \mathrm{~km} / \mathrm{hr}) ;(\mathrm{I})$ is older $(356 \mathrm{~km} / \mathrm{hr})$. C, Profile of nonvolcanic avalanche at Avalanche Lake, North West Territories (Evans and others, 1994, fig. 6) (403 km/hr). D, Profiles of Augustine: summit north-northeastward through Burr Point, and summit westnorthwestward through West Island.
Avalanche Lake (Northwest Territories, Canada) rock avalanche, in a fairly uncomplicated field situation, achieved an astonishing runup of $640 \mathrm{~m}$ (fig. $57 \mathrm{C}$ ). The simple conservation-of-energy calculation above requires a minimum velocity of $112 \mathrm{~m} / \mathrm{s}$ just before runup. But because the run-up toe of this slide - just 2.5 percent of the whole volume of the slidebegan its journey $500 \mathrm{~m}$ below the level it came to rest (Evans and others, 1994, fig. 11), this situation shows clearly the runup mass could not have flowed solely by its own momentum. It had to have been shoved from behind by higher parts of the slide mass that could achieve higher momentum.

So. If a debris avalanche can transfer momentum from its head to its toe, the simple relation $v=\sqrt{2 g h}$ can yield a calculated velocity too high — rather than being a minimum velocity as often imagined. The shove-from-behind idea is implicit in several dynamic models (Savage and Hutter, 1989,
1991; Iverson and Denlinger, 2001; Denlinger and Iverson, 2001; McDougall and Hungr, 2003). To the Avalanche Lake slide, Hungr applied dynamic simulations that include longitudinal forces, a push from behind (Evans and others, 1994, fig. 17). Calculations from centers of mass before and after the slide yield maximum velocity of $80 \mathrm{~m} / \mathrm{s}$ - or 71 percent of the "minimum" velocity from the relation $v=\sqrt{2 g h}$. The exercise for Avalanche Lake provides an arithmetic means to down-scale the high velocities for the volcanic avalanches cited above. Thus a velocity for the Mount St. Helens slide just before runup - if assisted by a push from behind - reduces from $87 \mathrm{~m} / \mathrm{s}$ to about 61 to $65 \mathrm{~m} / \mathrm{s}$. The two Plinth Peak avalanches thus reduce to about 67 and $70 \mathrm{~m} / \mathrm{s}$. By analogy to these examples, speeds at which Augustine debris avalanche (fig. 57D) enters seawater scales back to between 60 and 80 $\mathrm{m} / \mathrm{s}(215$ to $290 \mathrm{~km} / \mathrm{hr})$. Whatever the velocity a slide enters 
Table 4. Some historical tsunami caused by nonvolcanic landslides and by volcanic debris avalanches.

\begin{tabular}{|c|c|c|c|c|c|c|c|c|}
\hline $\begin{array}{c}\text { Mountain, volcano, } \\
\text { or bay }\end{array}$ & Region & Year & $\begin{array}{c}\text { Slide volume } \\
\left(\mathrm{km}^{3}\right)\end{array}$ & $\begin{array}{c}\begin{array}{c}\text { Wave runup } \\
\text { height }(\mathrm{m})\end{array} \\
\end{array}$ & $\begin{array}{l}\text { Distance } \\
\text { away }(\mathbf{k m})\end{array}$ & Fatalities & Reference & Comment \\
\hline \multicolumn{9}{|c|}{ Nonvolcanic } \\
\hline Mayuyama & Japan & 1792 & 0.54 & & 22 & 14,524 & $\begin{array}{l}\text { Aida (1975), Ui and others (1986), } \\
\text { Bryant (2001) }\end{array}$ & $\begin{array}{l}\text { Off Mayuyama, not off Fugendake } \\
\text { erupting nearby. Yet often classified } \\
\text { as a volcanic debris avalanche }\end{array}$ \\
\hline Goldau & Switzerland & 1806 & .02 & $5-15$ & $1-4$ & many & Eisbacher and Clague (1984, p. 156-159) & Large slide into close lake \\
\hline Fjords & Norway & $\begin{array}{r}1660- \\
1967\end{array}$ & $.001-.015$ & 20 & $5-50$ & 240 & Jørstad (1968) & $\begin{array}{l}\text { Confined bays; } 50 \text { separate cases, } \\
10 \text { as rockslides }\end{array}$ \\
\hline Loen Lake & Norway & $\begin{array}{l}1905 \\
1936\end{array}$ & $\begin{array}{c}.00035 \\
.001\end{array}$ & $\begin{array}{c}1-40.5 \\
3-74\end{array}$ & $\begin{array}{l}1-7 \\
1-7\end{array}$ & $\begin{array}{l}61 \\
73\end{array}$ & $\begin{array}{l}\text { Bjerrum and Jørstad (1968); Slingerland } \\
\text { and Voight (1979); Fritz (2002) }\end{array}$ & \\
\hline Scotch Cap & Alaska & 1946 & $?$ & 35 & $100+?$ & 5 & $\begin{array}{l}\text { Lander (1996); Walter Dudley, oral } \\
\text { commun., } 2000\end{array}$ & $\begin{array}{l}\text { Earthquake probably shook loose } \\
\text { submarine landslide, which caused } \\
\text { large tsunami }\end{array}$ \\
\hline Lituya Bay & Alaska & 1958 & & $10-525$ & & 0 & Miller (1960) & $\begin{array}{l}\text { Steep fall to confined bay; most recent } \\
\text { of several }\end{array}$ \\
\hline Vaiont & Italy & 1963 & & 35 & & & Kiersch (1964) & Steep slide into reservoir \\
\hline $\begin{array}{l}\text { Prince William Sound } \\
\text { area (many sepa- } \\
\text { rate slides) }\end{array}$ & Alaska & 1964 & various & $20-52$ & & & Plafker and others (1969) & $\begin{array}{l}\text { Many earthquake-triggered submarine } \\
\text { slides; tsunami deposits are boulders }\end{array}$ \\
\hline Kenai Lake & Alaska & 1964 & .000004 & $2-22$ & $1-4$ & 0 & McCullough (1966) & $\begin{array}{l}\text { Earthquake-triggered collapse of delta } \\
\text { fronts in confined lake }\end{array}$ \\
\hline Yanahuin Lake & Peru & 1971 & .0001 & $5-30$ & 0.5 & 600 & Fritz (2002) & \\
\hline Skagway & Alaska & 1994 & & 11 & 1.5 & & $\begin{array}{l}\text { Kulikov and others (1996); Plafker } \\
\text { and others (2000) }\end{array}$ & \\
\hline Bismark Sea & $\begin{array}{c}\text { Papua New } \\
\text { Guinea }\end{array}$ & 1998 & & $3-15$ & $20-30$ & $>2,200$ & Tappin and others (1999) & $\begin{array}{l}\text { Earthquake triggered submarine land- } \\
\text { slide, which generated tsunami }\end{array}$ \\
\hline \multicolumn{9}{|c|}{ Volcanic } \\
\hline Komagatake & Japan & 1640 & 0.3 & 8.5 & $35-50$ & 700 & Nishimura and Satake (1993) & \\
\hline Oshima-Oshima & Japan & 1741 & 0.4 & & $60-100$ & 1,475 & Ui and others (1986) & \\
\hline Mayuyama & Japan & 1792 & & & & & & (See above) \\
\hline Ruang & Indonesia & 1871 & & 25 & & & Padang (1959), Blong (1984) & \\
\hline Krakatau & Indonesia & 1883 & & $5-36$ & $36-120$ & $\begin{array}{c}35,500 \\
\text { (tsunami) }\end{array}$ & $\begin{array}{l}\text { Verbeek in Simkin and Fiske (1983), } \\
\text { Latter (1981), Francis (1985); Carey } \\
\text { and others (1996); Winchester (2003) }\end{array}$ & $\begin{array}{l}\text { Huge pyroclastic flows } \\
\text { and collapsing caldera }\end{array}$ \\
\hline Augustine & Alaska & 1883 & 0.35 & 6 & 90 & None? & $\begin{array}{l}\text { Alaska Commercial Co. (1883); } \\
\text { Davidson (1884) }\end{array}$ & $\begin{array}{l}\text { Harbor waves reported at } 8-9 \mathrm{~m} \text { prob- } \\
\text { ably exaggerated }\end{array}$ \\
\hline Ritter Island & Melanesia & 1888 & 5 & $7-15$ & $25-330$ & Many & $\begin{array}{l}\text { Cooke (1981), Johnson (1987), Ward and } \\
\text { Day (2003), Silver and others (2005) }\end{array}$ & \\
\hline Palaweh & Indonesia & 1928 & $<0.1$ & $5-10$ & & $\sim 200$ & Latter (1981) & \\
\hline Harimkotan & Kurile Is. & 1933 & $<0.4$ & 20 & 30 & 2 & $\begin{array}{c}\text { Belousov and Belousova (1996); A. } \\
\text { Belousov, oral commun. (2007) }\end{array}$ & \\
\hline Ili Werung & Indonesia & 1979 & 0.05 & 9 & & 540 & Blong (1984) & \\
\hline Mount St. Helens & $\begin{array}{c}\text { Washington, } \\
\text { USA }\end{array}$ & 1980 & & $>250$ & 2 & 0 & Waitt and Pierson (1994) & Large landslide into close lake \\
\hline Vulcano & Italy & 1988 & .0002 & $1-2$ & $0.5-2$ & 0 & Tinti and others (1999) & Very small landslide into shallow water \\
\hline Stromboli & Italy & 2002 & $\begin{array}{l}.02 \\
.006\end{array}$ & $6-10$ & $2-6$ & 0 & Tinti and others $(2005,2006)$ & $\begin{array}{l}\text { Small landslides into deep water; much } \\
\text { coastal damage on island }\end{array}$ \\
\hline
\end{tabular}


water, it slows to nil as it flows another $2 \mathrm{~km}$ or more against the resisting sea.

\section{Tsunami}

At least twelve debris avalanches off Augustine Volcano during the past about 2,200 years entered the sea (table 3, plate 1); that in 1883 (Burr Point) did so swiftly enough to generate a witnessed tsunami. Many other historical debris avalanches off alpine mountains or volcanoes have run into lakes or the sea fast enough to generate damaging waves along distant shorelines (table 4).

\section{Augustine Island, 6 October 1883}

Contemporary accounts (reproduced above in section “1883 Eruption") document that Augustine Volcano generated a tsunami experienced at English Bay. The unpublished later letter of November 1884 from Davidson to the Superintendent of U.S. Coast and Geodetic Survey includes a verbal picture from Capt. Cullie of Alaska Commercial Company as he sailed close around Augustine Island in June 1884. Thus the 1883 landslide off Augustine left a semicircular summit crater and a hummocky deposit spread about Augustine's north shore—new Burr Point (figs. 40, 42, 43).

An instrumental record of the 6 October 1883 tsunami exists: a tide-gauge drum record (marigram) from St. Paul (Kodiak) harbor on Kodiak Island. To understand characteristics of such records, reader is referred to general discussions of tide-gauge records of tsunami (Lander and Lockridge, 1989, p. 1-15; Lander and others, 1993, p. 1-9; Lander, 1996, p. 1-9 and 143). Thus for tide gauges to perform their primary function of precisely recording very low-frequency tidal

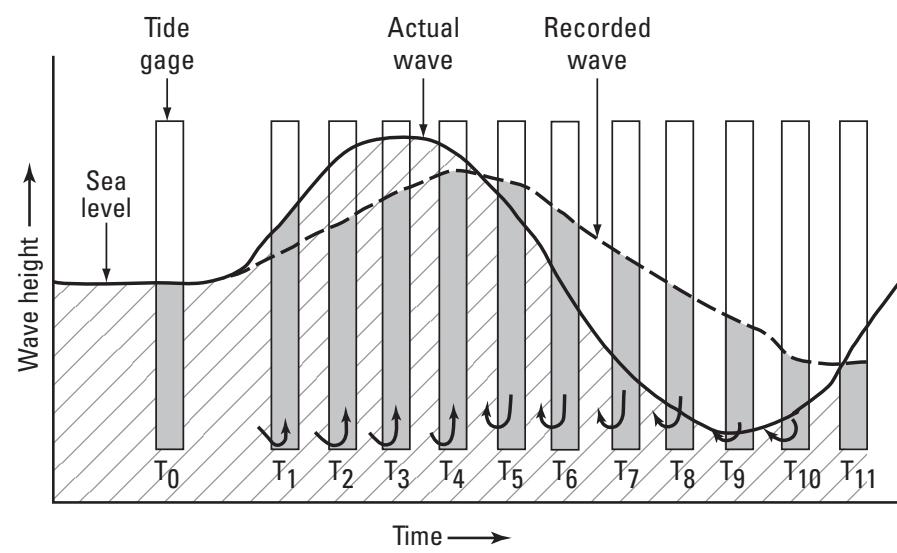

Figure 58. Schematic sketch illustrating how the stilling well in tide gauges causes (1) a decrease in recorded wave height and (2) a delay in recorded peak height from the actual wave. Redrawn from Lander and Lockridge (1989, fig. 6), Lander and others (1993, fig. 31), and Lander (1996, fig. 47).

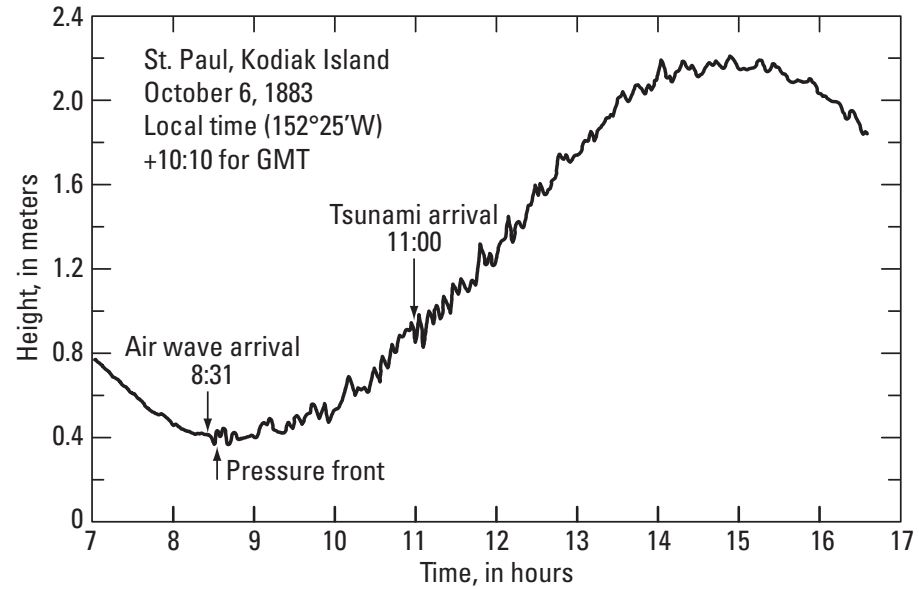

Figure 59. Tide-gauge marigram from St. Paul (Kodiak), Alaska on 6 October 1883 showing arrivals of wave train of air wave and of tsunami from Augustine, both superimposed on a tidal cycle of 1.8-m amplitude. Marigram retrieved from U.S. Coast and Geodetic Survey archives by James F. Lander (see Lander, 1996, p. 49 and fig. 16) (see text for explanation). The 1883 tide gauge probably was at town pier at Kodiak (St. Paul Harbor at about longitude $152^{\circ} 25^{\prime}$ W). Time is local sun time, before advent of global time zones in 1884. For GMT add about 10:10 hours. First motion in tide gauge for air-pressure wave (that depresses sea surface) is logically negative but for tsunami (that raises sea surface) is positive.

fluctuations, they have but a small inlet hole into a stilling well, a design that filters from the record high-frequency "noise" like wind waves and boat wakes - and so also tsunami. These stilling effects cause a slight time lag between the actual arrival of a wave at the gauge and its registry by the pen recorder (fig. 58). Also the recorded range may be far smaller than actual range for a tsunami wave, owing to these same damping of high-frequency effects by the tide gauge. Once a tsunami enters a confined harbor like Kodiak, the gauge may record standing waves (seiches) sloshing about inside the harboraside from further waves of a tsunami train still invading the harbor. And for tsunami initiated by volcanic eruption, explosions broadcast pressure waves that may couple with the water surface to produce small "air-wave" pseudotsunami long ahead of true tsunami traveling as water waves. Such air-wave excitation and slower moving true tsunami are much analyzed for the Krakatau eruption in Indonesia in late August 1883 (Ewing and Press, 1955; Harkrider and Press, 1967; Yokoyama, 1981; Latter, 1981; Francis, 1985; Winchester, 2003).

The Kodiak marigram of 6 October 1883 shows a tidal oscillation of amplitude $1.8 \mathrm{~m}$. Superimposed on it are two high-frequency signals, interpreted by Lander (1996, p. 49) as air-wave arrival followed by tsunami arrival (fig. 59). The gauge registers the air wave at 08:31, the sea wave (tsunami) at 11:00. A 2 $1 / 2$-hour travel time of sea wave from Augustine to Kodiak harbor is consistent with an approximately 2-hour travel time of a prediction model run in 1995 for a north-Augustine source 
by Paul Whitmore of Alaska Tsunami Warning Center (fig. 60) (Lander, 1996, fig. 15). The apparent first arrival of the Augustine air wave at Kodiak harbor is negative (fig. 59), as expected of a pressure wave depressing the sea surface. The apparent first arrival of the true tsunami wave is positive, as expected of a wave initiated by landslide raising the sea surface. The regular wave train after this first arrival may be partly seiching of that wave within Kodiak harbor. The maximum range of the sea wave scaled from the marigram is 19 to $20 \mathrm{~cm}$. The actual range may well have been higher, the record damped by the gauge's small intake hole and its stilling well. A similar pattern of air waves far ahead of tsunami is shown by tide-gauge records of 1883 Krakatau effects (Latter, 1981, fig. 3).

\section{Analysis of 6 October 1883 Records}

The air wave of the Kodiak marigram must record an explosive eruption. Traveling at sound speed (about $331 \mathrm{~m} / \mathrm{s}$ ), the air wave covers the $185 \mathrm{~km}$ air distance in about $9.3 \mathrm{~min}$ utes. Its recorded arrival at 08:31 local time implies initiation at Augustine at about 08:22 (fig. 61) — or perhaps a bit earlier if one assumes a short delay for the wave to transmit through the gauge's aperture and stilling well to the recorder. In this era before the adoption in 1884 of global time zones, local time is "sun time" (Lander, and Lockridge, 1989, p. 8; see popular discussion by Sobel, 1995, p. 5 and 167-168). Maintained by the U.S. Coast and Geodetic Survey, the St. Paul tide gauge's sun-time clock probably was accurately set. English Bay lies 30 minutes of longitude east of St. Paul (Kodiak) harbor: English Bay sun time is 2 minutes ahead of Kodiak sun time.

Initiation of the marigram's primary air wave by explosion at Augustine at 08:22 or slightly earlier is crudely consistent with Davidson's report of eyewitnesses at English Bay that the first heavy report from Augustine was at about 08:00. Traveling at sound speed, an air wave covers the $85 \mathrm{~km}$

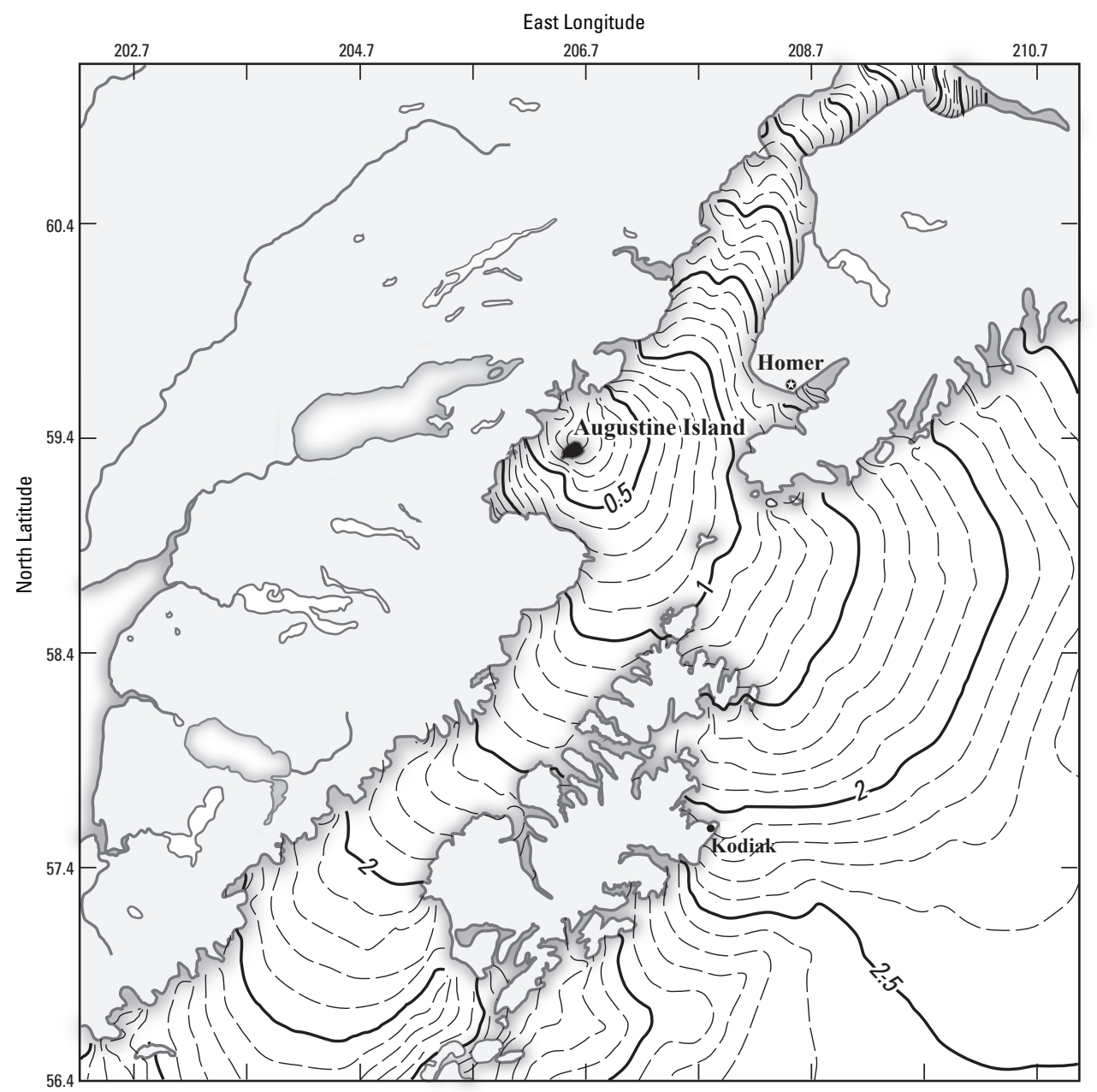

Figure 60. Tsunami travel times (in hours) from north flank of Augustine Island plotted in 1995 by Paul Whitmore of West Coast/Alaska Tsunami Warning Center in Palmer, Alaska. Contour interval, 6 minutes; index contours (heavy solid lines) labeled in hours. The fractional values for North Latitude and East Longitide are artifacts of the plotting routine. (Retraced from figure 15 in Lander [1996] but cropped on east and south; used by permission of Paul Whitmore). 


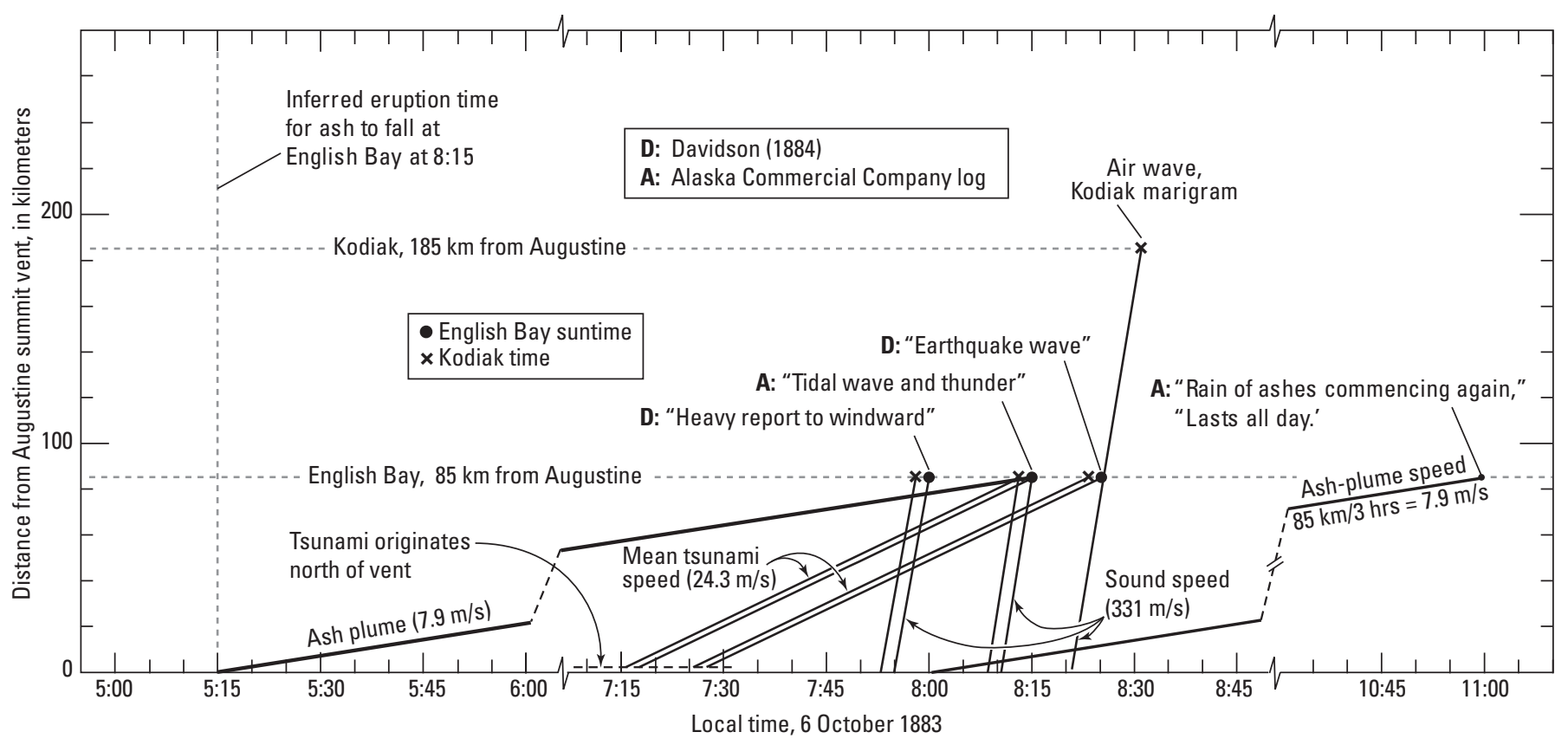

Figure 61. Timing of contemporary records of initial events in morning 60 ctober 1883 eruption of Augustine Volcano. By longitudecalculated sun time (before global time zones established in 1884), English Bay time (•) is 2 minutes ahead of Kodiak time (x). The plotted points $(\bullet$ and $x$ ) are three eyewitness observations at English Bay and the first arrival of the air wave of the Kodiak marigram (fig. 59). English Bay time (•) is also plotted in Kodiak time $(\mathrm{x})$. Sound speed $(331 \mathrm{~m} / \mathrm{s})$ and mean tsunami speed through an average $60 \mathrm{~m}$ water depth $(24.3 \mathrm{~m} / \mathrm{s})$ are projected from these points back in time to Augustine Island to discover approximate initiation times.

Explosion-like sounds reported at English Bay $85 \mathrm{~km}$ away would have originated at Augustine between 07:55 and 08:11 by English Bay time — or between 07:53 and 08:09 by Kodiak time. The tsunami observed at English Bay would have been underway from Augustine earlier, between 07:15 and 07:26-it had initiated at Augustine's north shore some 2 to 1 hour before the explosion(s) from Augustine's vent were heard at English Bay.

The ashfall reported at 11:00 (by Alaska Commercial Company [A.C.C.] log, 1883) seemingly results from the sound and sight of eruption at about 08:00 (by Davidson, 1884) — a very plausible time interval for ash to drift the $85 \mathrm{~km}$ from volcano to English Bay. And so this same 3-hour time interval is projected back from the approximate 08:15 start of ashfall at English Bay (by A.C.C. log) to infer time of first 6 0ctober 1883 eruption of Augustine at about 05:00 a.m.

to English Bay in about 4.3 minutes. Subtracting this and the 2-minute difference in sun time, Davidson's "heavy report to windward" would begin about 07:53 Kodiak time, about 29 minutes before the airwave recorded by the marigram (figs. 60, 61) - if Davidson's times are correct. By the same arithmetic the $08: 15$ of the Alaska Commercial Company (A.C.C.) log when "it began to thunder" would have initiated at Augustine about 08:08 Kodiak time, or about 15 minutes ahead of the air wave of the Kodiak marigram. Perhaps there were a few Augustine explosions, variously remembered and reported at English Bay.

Time between the first explosion of 6 October 1883 reportedly seen and heard at English Bay at about 08:00 and then tsunami at about $08: 15$ (by A.C.C. $\log$ ) or about 08:25 (by Davidson's account) is far too short for the visual event to have occurred at the time the tsunami originated (tsunami travel time discussed below). Figure 61 shows that a tsunami would have been initiated at about 07:17 or 07:27 (Kodiak time) to have arrived at English Bay at the $08: 15$ or $08: 25$ (English Bay time). Yet the May 1980 Mount St. Helens eruption suggests an explanation. After its initial landslides (in that case triggering a spectacular surge cloud and thus also an immense upward mushroom cloud), emission from the Mount St. Helens vent was feeble for half an hour. Only gradually did it form a vigorous high jet visible from far away (Criswell, 1987). Stratigraphy on Augustine Island shows that the 1883 Burr Point landslide did not trigger a directed surge ("blast") that would be visible from the mainland. The landslide must have occurred unseen half an hour to an hour before the beginning of observed venting. During Augustine's 1986 eruption, explosive activity visible from a distance too waxed only gradually (Power, 1988).

During an explosive eruption at Augustine, an ashcloud takes far longer to drift the $85 \mathrm{~km}$ to English Bay than it takes a sound wave to travel the same distance. Davidson's (1884) "heavy report to windward" and "vast and dense volumes of 
smoke ... rolling out of the summit of St. Augustin ... northeastward" at about 08:00 must be the cause of the A.C.C. logbook entry: "Rain of Ashes commencing again at 11. o'clock A.M. ..." - thus about 3 hours for the eruption cloud to drift $85 \mathrm{~km}$ east-northeast to English Bay (fig. 60). ${ }^{17}$ The 10-minute ashfall at English Bay at 08:15 a.m. or so (A.C.C. account) suggests an earlier eruption from Augustine at roughly $05: 15$ - two hours or so before the landslide initiates the tsunami (fig. 60).

The small amplitude of the 6 October 1883 tsunami disturbance to the tidal cycle at St. Paul (Kodiak) is consistent with the sea distance of at least $250 \mathrm{~km}$ from Burr Point to Kodiak, the tsunami waves arriving via refracted and reflected paths into a bay on Kodiak Island's far side and the tide gauge

${ }^{17}$ Ash plumes ejected during Augustine's 2006 eruptions typically took 2 to 4 hours to reach inhabited areas of Kenai Peninsula to the east and northeast (Alaska Volcano Observatory at website http://www.avo.alaska.edu; Power and others, 2006; Begét and others, 2007).

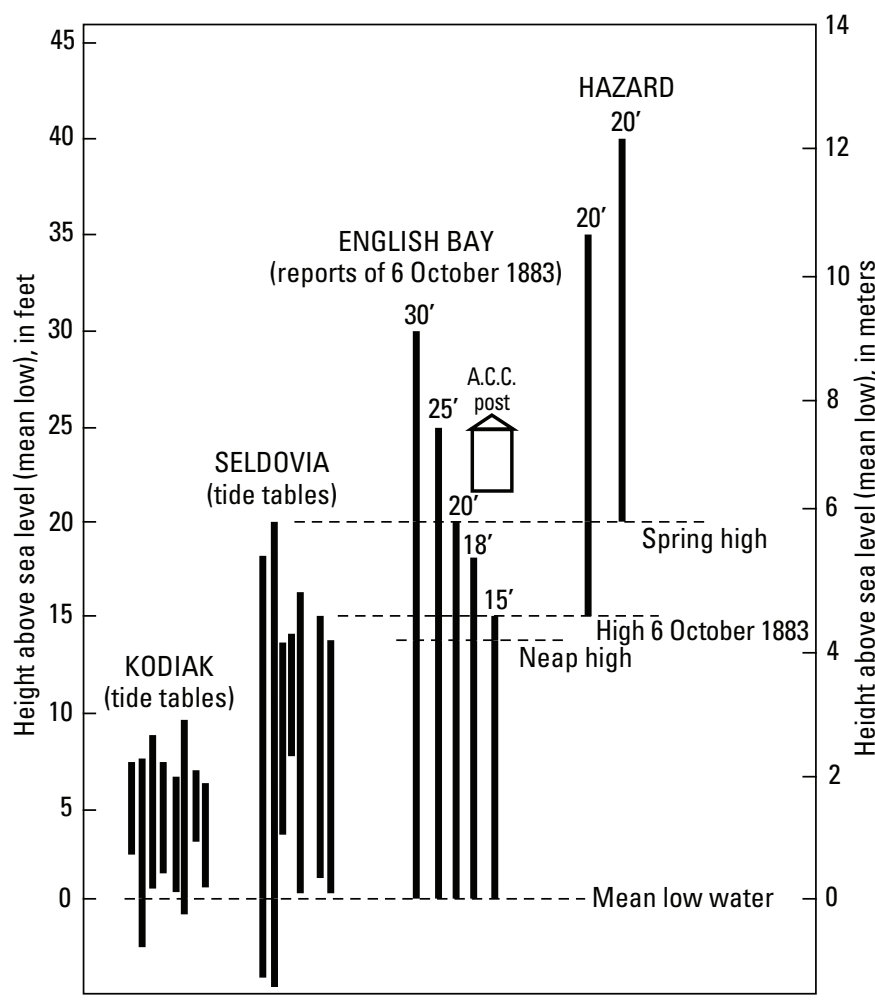

Figure 62. Plot of variation in tidal ranges at Kodiak, Seldovia, and English Bay (Nanwalek), Alaska. Cluster of ranges at Kodiak and Seldovia are typical tides from 1995 predictive tide tables for Kodiak and Seldovia. Included are the 6 October 1883 marigram range (for Kodiak) and Davidson's (1884) $14 \mathrm{ft}$ at English Bay (for Seldovia). Dashed line is height of maximum (spring) high tide for Seldovia. English Bay shows the five tsunami-height figures reported by the 60 ctober 1883 eyewitness accounts. Mean low water is the approximate tidelevel at the time of tsunami on 6 October 1883. A.C.C., Alaska Commercial Company. itself wave-damped. The arrival of an air wave far ahead of water waves at Kodiak on 6 October 1883 resembles patterns of the far more dramatic sea-surface effects from the eruption of Krakatau in Indonesia six weeks earlier as recorded by tide gauges in the southwest Pacific (Latter, 1981, fig. 3).

By 1995 tide tables, tides at Seldovia $14 \mathrm{~km}$ north of English Bay rise and fall as much as $23.8 \mathrm{ft}(7.3 \mathrm{~m})$ for spring tide and as little as $5.3 \mathrm{ft}(1.6 \mathrm{~m})$ for neap tide. The average monthly rise and fall is thus about $14.5 \mathrm{ft}(4.4 \mathrm{~m})$, approximately the figure stated by Davidson (1884) for tidal range (fig. 62). At Kodiak the tidal range varies between 3.0 and $0.9 \mathrm{~m}$. The $1.8-\mathrm{m}$ tidal range of the Kodiak marigram indicates an intermediate tidal range for 6 October 1883. Thus Davidson's "fourteen feet" $(4.3 \mathrm{~m})$ for tidal range approximately applies to English Bay for the intermediate-range tide of 6 October 1883. A 6-m tsunami ("20 feet" of A.C.C. $\log$ ) occurring at low tide (according to Davidson, 1884) would have risen about to the limit of 1883 spring high tides at English Bay (fig. 62). A 7-m tsunami would have risen a little above spring high tide. That would account for the "deluging the houses" and "moving the huts" in the contemporary accounts by Dall (1884), Davidson (1884), and Heiromonk Nikita (see "1883 Eruption").

The Alaska Commercial Company's post was on the spit at English Bay—renamed in 1991 to Nanwalek, meaning "place by lagoon." Since 1955 the site of the former post has been an airport runway. It sits about $6 \mathrm{~m}$ above mean lower low water. But this area subsided about $1.1 \mathrm{~m}$ with respect to sea level in the 1964 earthquake (Plafker, 1969). So in 1883 the Alaska Commercial Company post stood $7 \mathrm{~m}$ or so above low water, a little above the limit of spring high tide. The post's log entries for 6 October 1883 and succeeding days do not suggest that the post and its trading goods were at all inundated by sea waves - damage that would have been important enough to the post's commerce to show in its meticulous logbook. The absence of reported damage accords with the estimate in the Company log of a "20 feet above usual level" for tsunami height. Dall's (1884) "thirty feet height" and Davidson's (1884) wave heights of " 25 to 30 feet" ( 8 to $9 \mathrm{~m}$ ) probably would have reached the trading post enough to cause damage, and therefore these values seem a little too high. But the four contemporaneous accounts (including Nikita's) are entirely consistent with a tsunami rise of 20 to $23 \mathrm{ft}$ ( 6 to $7 \mathrm{~m}$ ).

Might a great earthquake have independently generated the 1883 tsunami? Instrumental detection of earthquakes in Alaska did not begin until 1898, but Davies and others (1981) list earlier historical events reported in newspapers, diaries, and other local sources for the Kodiak-Shumagin region. The years of largest shocks are 1788, 1792, 1844, 1847, 1854, $1868,1880,1899,1900$, and 1903. Other detailed research of written records (Soloviev and Go, 1984; Lander and others, 1993; Lander, 1996) reveals no earthquake or tsunami originating in the Pacific basin on 6 October 1883. Apparently no large regional or distant earthquake caused the 1883 tsunami in lower Cook Inlet. The waves could only have come from the observed eruption of nearby Augustine Volcano as contemporaneous accounts infer. 


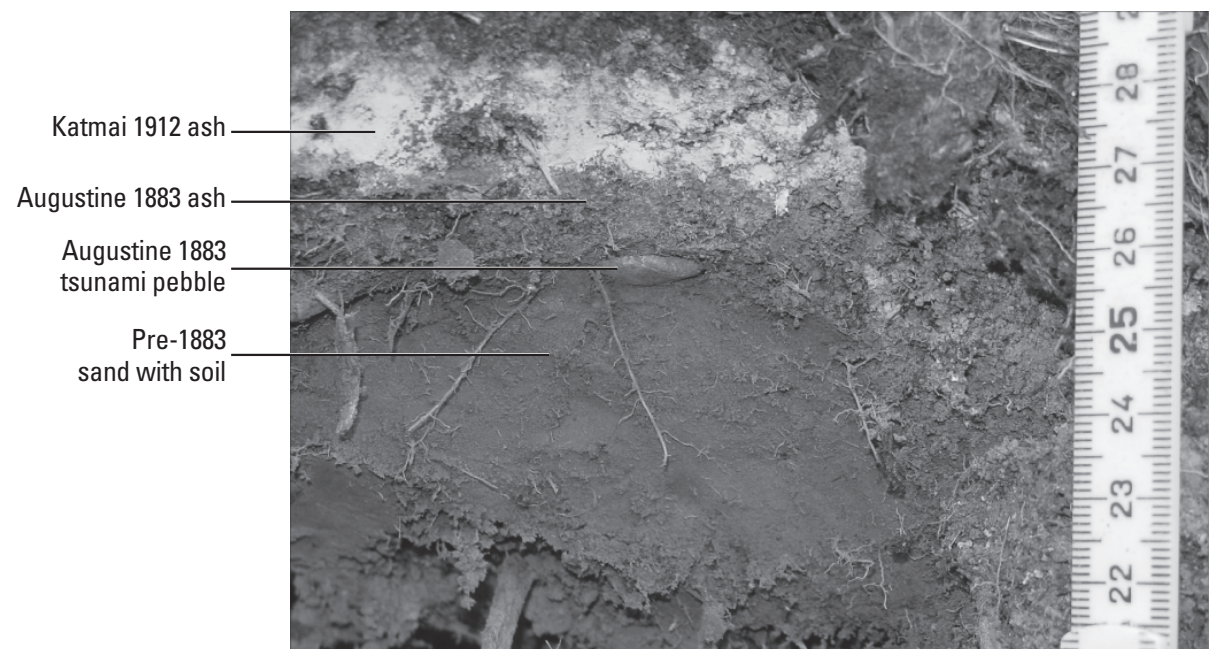

Figure 63. View of 1883 tsumani and ashfall deposits near Nanwalek (in 1883 called English Bay). Overlying a brown soil developed over time on sand are beach pebbles transported up to 12 meters above high-tide level, evidently by tsunami in early morning 6 0ctober 1883. Immediately above the pebbles lies $12 \mathrm{~cm}$ of fine-sand ash evidently of 1883 ashfall deposited 6-7 Oct 1883; overlying that is the unmistakable Katmai 1912 white-silt ash. A different view of identical stratigraphy 10 meters away appears in Begét and Kowalik (2006, fig. 5). (Photograph by J.E.Begét.)

\section{Evidence on Augustine Island for Augustine Tsunami}

Augustine Island contains some direct evidence of 1883 tsunami. Burr Point debris avalanche ran as much as $4 \mathrm{~km}$ beyond the preeruption sea cliff on the north-northeast coast (fig. 11), and atop some avalanche hummocks lie thick clasts of deformed mud containing exotic stones and early Holocene marine shells scraped from the former bay. These relations show that the 1883 avalanche slammed into the bay at high speed and momentum. The shelly clasts of mud show that central parts of the Burr Point avalanche violently raised seawater at least $13 \mathrm{~m}$ above modern spring-high tide line. And atop outer Burr Point hummocks, pockets of shellcontaining sand, isolated driftwood, and water-erodeded hummocks reaching 3 to $5 \mathrm{~m}$ above spring-high tide seem to be tsunami effects.

The larger West Island debris avalanche of age about $370 \mathrm{yr}$ B.P. overrode and strongly fluted the sea cliff that marked the former northwest coast. Almost all the avalanche mass rode well beyond the cliff into the sea - as much as $5 \mathrm{~km}$ beyond - evidence that this bouldery mass plowed into the sea at very high speed and momentum. In the planed-off southern hummocks, West Island contains direct evidence of a tsunami caused by this mass. Lagoon avalanche just south of West Island avalanche too has been washed up to $8 \mathrm{~m}$ above sea level and possibly also North Bench avalanche just east of West Island avalanche.

\section{Evidence on Mainland for Augustine Tsunami}

A sand layer containing fine gravel, rounded large beach cobbles, abundant driftwood, and fallen local trees overlies about 300 yr B.P. Iliamna volcaniclastic deposits at Red River delta on the west coast of Cook Inlet (fig. 1A) $67 \mathrm{~km}$ north-northeast of Augustine's Burr Point (Anders and Begét, 1999). The deposit lies about 1.5 to $2 \mathrm{~m}$ about current high tide. Radiocarbon dates on the driftwood are about 90 to $100 \mathrm{yr}$ B.P. (with large statistical errors); dendrochronology of trees rooted below the gravelly-sand layer shows a tree-ring perturbation (a few years of wider rings) dates to A.D. 1883 (Anders, 1999). The most likely cause of this deposit is the 1883 tsunami from Augustine that eyewitnesses reported at English Bay on the east side of Cook Inlet. The deposit on Red River delta lies on a point where computer models (see below) predict tsunami wave height should be high.

An apparent 1883 tsunami deposit crops out on the south and east of the sand spit that guards the harbor of the village of Nanwalek (English Bay). About 12 meters above spring high-tide level, the deposit consists of sand and rounded pebbles to small cobbles that overlie a brown soil developed on older silt (fig. 63). The pebbles and sand evidently washed upslope in the tsunami observed between 8:15 and 8:25 a.m. on 6 October 1883. Directly overlying the pebbles are several centimeters of gray fine-sand ash (fig. 63), surely the ashfall from Augustine on 6 and 7 October 1883 reported in the contemporary accounts (A.C.C., 1883; Dall, 1884; Davidson, 1884). The gray-sand ash is in turn overlain by the distinctive regional white-silt ash from Katmai eruption of 1912 (see also Begét and Kowalik, 2006; Begét and others, 2007).

An 1883 tsunami deposit may be preserved in sediment in Beluga Lagoon near Homer. Several shallow cores from the lagoon recovered sequences of mud interrupted by two beds of sand and gravel each 1 to $2 \mathrm{~cm}$ thick (fig. 64). Historical observations suggest the upper layer was deposited by tsunami during the 1964 earthquake. The lower sand and gravel bed at depth 20 to $50 \mathrm{~cm}$ is directly overlain by a thin organic horizon mixed with volcanic ash that chemically fingerprints as Katmai 1912 eruption and Augustine 1883 eruption (J.E. Begét, unpub. data). Thus the coarse sand-and-gravel bed just below these ashes must record an 1883 Augustine tsunami. These cores at the limit of spring-high tide to a half meter below don't reveal if the 1883 tsunami at Homer rose above highest tides. 
Prehistoric possible tsunami deposits - beds of sand and water-rounded cobbles as thick as 5 to $7 \mathrm{~cm}$-lie within thick peat beds near Nanwalek and Seldovia as much as $5 \mathrm{~m}$ above high tide (Begét and Gardner, 2004; Begét and others, 2008). These deposits overlie peat dated to about $1,620-1,650{ }^{14} \mathrm{C}$ yr B.P. They are thus close in age to the voluminous Northeast Point debris-avalanche deposit that overrode a sea cliff and crashed into deep water off Augustine Island's east coast (plate 1; tables 2 and 3 ).

Another likely prehistoric tsunamigenic deposit (discovered by C.F. Waythomas in 1995) lies at the bedrock headland of Point Bede on lower Kenai Peninsula about $5 \mathrm{~km}$ south of Nanwalek (fig $1 A$ ). The deposit is of very angular boulders as large as $1.3 \mathrm{~m}$ thrown as much as $10 \mathrm{~m}$ back from a $3-\mathrm{m}$ sea cliff and 1 to $2 \mathrm{~m}$ above high tide.

Three blocks a meter or so in diameter and dozens of smaller ones, all very angular, derive from an outcrop in the hightide surf zone just seaward. Overlying some of the boulders is a peaty accumulation containing two to four laminae of sand-silt ash beneath the distinctive Katmai 1912 ash. These ashes - resembling the ash stratigraphy overlying the West Island debris avalanche (fig. 35 and plate 2) - show that the boulders were cast onto Point Bede at least a few centuries before 1883 .

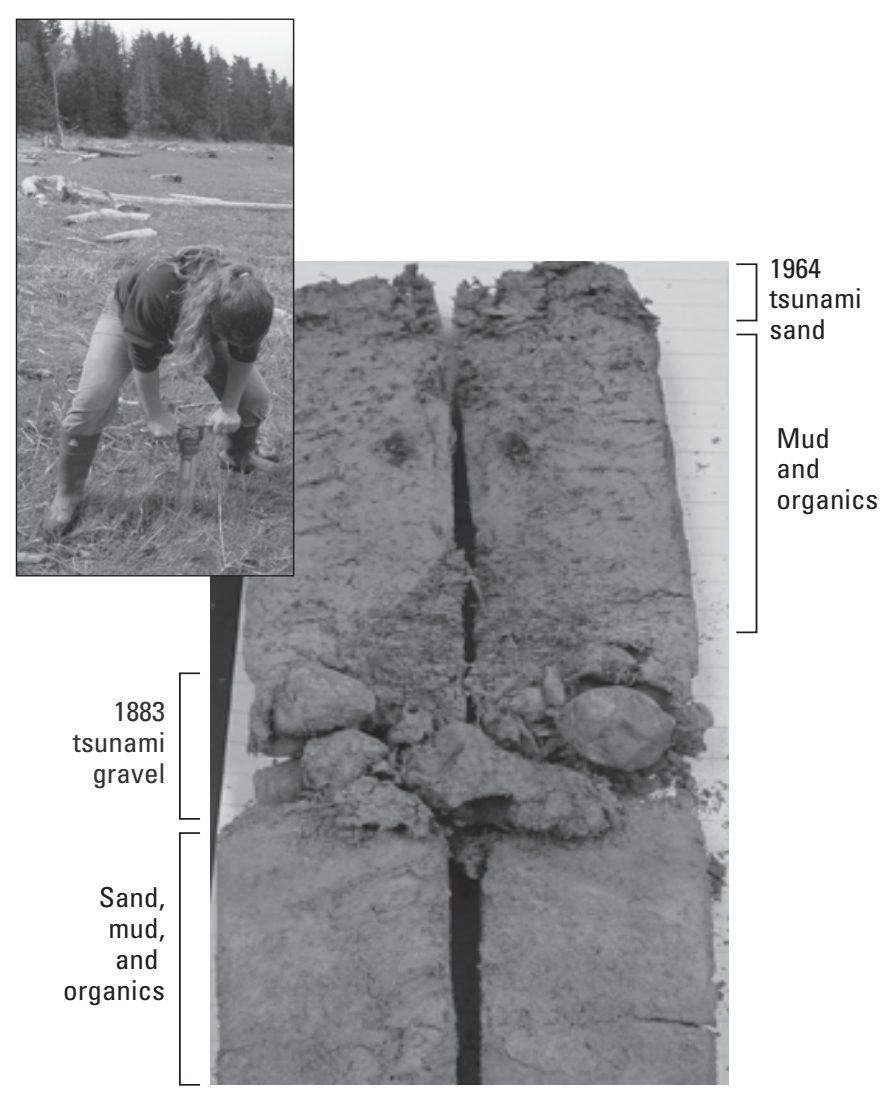

Figure 64. Photo of core from Beluga Lagoon near Homer with sand-gravel bed of 1883 Augustine tsunami. Inset photo shows core being obtained. (Photographs by J.E.Begét.)

\section{Sparseness of Mainland Evidence for Augustine Tsunami}

Besides the deposits at Red River delta, Nanwalek (English Bay), and Homer studied by Begét and colleagues, no other definitive evidence of a 1883 tsunami has yet been deciphered along the shores of lower Cook Inlet. In 1991 Waitt and B.F. Atwater examined several likely sites on the east and west sides of lower Cook Inlet in search of 1883 and older tsunami deposits, and Waitt further explored coasts near Homer in 1992-95. We found two candidate deposits, both clearly older than 1883 , both later rejected as tsunami deposits. C.F. Waythomas and others repeated this field exercise in 1995 along these coasts and again found no evidence of an 1883 tsunami (Waythomas, 1997). But the 1883 tsunami is directly recorded by historical accounts like the five cited above.

Many students of tsunami elsewhere have commented on a typical sparseness of lasting geologic evidence of historical tsunami, even along erodable sandy coasts. Papua New Guinea was struck in July 1998 by tsunami as high as 10 to $15 \mathrm{~m}$. Along a sand-spit reach of the coast, the field-survey team "had to act quickly . . . because water marks and other indicators are highly ephemeral and can be lost after even a single heavy storm" (Kawata and others, 1999, p. 104).

Much of the tsunami-deposit literature dwells on such sand sheets spread inland from broadly low-lying sandy coasts. But most coastlines of Cook Inlet consist of rocky cliffs and it is coarse material that abounds. Several local tsunami caused by submarine landslips during the great 1964 Alaska earthquake left mainly ephemeral effects like smashed trees and diverse wooden and marine-organic flotsam (Plafker and Kachadoorian, 1966; Plafker and others, 1969). As permanent deposit they typically left not sand but boulders (Plafker and others, 1969). Sparsely distributed boulder deposits and water-stripped headlands are the main or only evidence for powerful prehistoric tsunami that have swept many coasts in Australia, Caribbean and Pacific islands, Portugal, and Japan (Andrade, 1992; Jones and Hunter, 1992; Kawana and Nakata, 1994; Bryant and Young, 1996; Young and others, 1996; Nott, 1997, 2000, 2003; Bryant, 2001, 2008; Bryant and Nott, 2001; Nott and Bryant, 2003; Scheffers, 2002; Frolich and others, 2009). The only physical evidence for a tsunami (or arguably large storm surge) that on 30 January 1607 swept up Bristol Channel and Severn Estuary between southwest England and south Wales is eroded salt marsh, wave-stripped headlands, and deposits of boulders (Haslett and Bryant, 2005; Bryant and Haslett, 2007).

Unlike flowage processes such as glaciers, streamflood, and debris flow that inherently move and deposit sediment, a tsunami is clear water devoid of sediment. It entrains sediment only as the current crashes ashore in its last moments. Prerequisites to a permanent deposit are abundant, loose sediment just seaward, and a deposit-retaining environment just landward. Few such sites exist in lower Cook Inlet. Most coasts are rocky or cliffy; beaches are few and most of them gravel. Small wonder the record in deposits is sparse. 


\section{Numerical Simulation of Augustine Tsunami}

Generation and propagation of tsunami involve various phenomena of initiation, propagation, and runup. Some processes, like propagation through deep water, are regular, understood, and reduced to linear equations. Time for a tsunami to propagate from Augustine Island to a mainland coast is estimated by the relation $V=\sqrt{d g}$, where $V$ is velocity of propagation, $d$ is depth of water, and $g$ is acceleration of the force of gravity (Lander and Lockridge, 1989, p. 3). From northside Augustine to Nanwalek (English Bay), $84 \mathrm{~km}$ across water of average depth about $60 \mathrm{~m}$, travel time is thus roughly $58 \mathrm{~min}$ utes. In Troshina's (1996) detailed model, propagation velocity is computed incrementally through cells of a grid; travel time is computed by summing the times to pass through each increment of distance at each instantaneous velocity. From Augustine Island to Nanwakek on lower Kenai Peninsula, this time varies among the model runs from 50 to 60 minutes.

Simulations by Troshina (1996), Kowalik and Murty (1989), Kienle and others (1987), and Begét and Kowalik (2006) show that an Augustine tsunami strikes coasts across Cook Inlet with greatest energy on broad headlands - between Homer and Anchor Point, and between Seldovia and Port Chatham (fig. 1A). Wave energy concentrates upon peninsulas as waves slow and refract when they cross from deep to shallow water. And three sites bearing geologic evidence of the 1883 tsunami (Red delta, English Bay, Homer) are areas numerical modeling suggests a tsunami generated by a northside Augustine landslide should concentrate (Begét and Kowalik, 2006). For Homer and English Bay, Troshina (1996) much improves resolution of bathymetry calculations and includes runup routines. For a landslide off Augustine's north side at low tide, her models "generate" wave runups at Nanwalek (English Bay) as high as $3 \mathrm{~m}$, compared with a value of $6 \mathrm{~m}$ or so reported there in 1883. For other patterns of Augustine landslides, Troshina's runups in lower Cook Inlet range 1 to $6 \mathrm{~m}$.

All numerical simulations of tsunami are limited in depicting nature: unproven assumptions enter the equations; the equations greatly simplify actual natural phenomena; they contain constants to be manipulated; bathymetry is insufficient, especially in near-coastal shallows; diverse processes in the shoals both at initiation site and in runup areas are physically complex and the simulating equations nonlinear; many complicating processes are ignored (Troshina, 1996, p. 11-28, and written and oral commun., 1995 and 1997; Elena Suleimani [formerly Troshina], oral commun., 2000, 2002, 2006). Tsunami models typically "underpredict" observed local maximum runup height by factors of 2 to 10 (Satake and Tanioka, 1994; Myers and Baptista, 1995; Synolakis and others, 1995; J. Bourgeois, oral commun., 1995; Tappin and others, 1999), while along a coast observed runup heights vary locally by factors of 2 to 5 . A recent numerical model of tsunami generated by Augustine landslides (Waythomas and others, 2006) reconfirms the limitations inherent in all numerical simulations. Of the initiation mechanism at Burr in 1883 they note: "Wave phenomena in the splash zone are complex and difficult to evaluate quantitatively, especially in nature, where it is typically impractical to obtain data on water behavior."

The numerical models of the 1883 Augustine northside tsunami "postdict" runups on Kenai Peninsula of $3 \mathrm{~m}$ or less where the observed height of the largest wave in 1883 was 6-7 m. Yet numerical simulations typically yield tsunami runups only a half to a tenth observed maximum runups. Elena Troshina (oral commun., 1997, 2002) reflects that with all the assumptions and numerical simplifications that such models embody, an output runup of half an observed runup is the best one should expect.

\section{Can Augustine Generate Large Tsunami?}

Subaqueous landslides, and subaerial landslides entering water, have caused numerous tsunami in historical times (table 4). Some very large prehistoric landslides in or into deep water have caused tsunami that have run up 20 meters and more on nearby coasts and sometimes hundreds of kilometers away (for instance, Moore and Moore, 1984; Moore and others, 1994; Bondevik and others, 1997, 2003; Bryant, 2001; Whelan and Kelletat, 2003). Scores of moderate others have sent tsunami across the sea to run up 5 to 10 meters on shores tens of kilometers away. The numerous tsunami deposits discovered since the early 1990s far above sea level around the world's oceans evoke Ted Bryant's apropos book title: Tsunami, the underrated hazard. A slide off Mayuyama into the adjacent shallow bay in 1792 took almost 15,000 lives (table 4). It was only a little larger than a large Augustine landslide into its adjacent sea.

Whether a northside debris avalanche from Augustine Volcano can generate a tsunami damaging to mainland coasts of lower Cook Inlet is an enduring question (Waythomas and Waitt, 1998). Several reports over the years argue "aye" (Johnston, 1977; Keinle and Swanson, 1983b; Kienle, 1986; Kienle and others, 1987; Siebert and others, 1989, 1995; Begét and Kienle, 1992; Siebert, 1992; Troshina, 1996). But othersmisunderstanding Augustine's field records and downplaying the contemporary accounts - argue "nay" on more theoretical grounds (Waythomas, 1996, 1997, 2000; Waythomas and others, 2006).

Population and development in lower Cook Inlet were trifling in the 1880s- Homer and Halibut Cove for instance lay in the future. Seldovia's 1880 population was only 74 , mostly natives (Klein, 1981), and with the fur industry declining even that much reduced by May 1883 (Jacobsen, 1977, p. 197). Native villages like Seldovia having until recently preserved their history orally, they left no permanent written records about the 1883 Augustine eruption and tsunami.

The train of tsunami waves as high as 6 or $7 \mathrm{~m}$ witnessed at English Bay on 6 October 1883 apparently originated when an avalanche of moderate volume swept into the shallow sea on Augustine's north shore. Judged by comparing the volcano's current summit with Doroshin's 1870 sketch (fig. 40A), Augustine's dome summit has grown back wider and taller during the 1883, 1935, 1964, 1976, 1986, and now 
2006 eruptions than it was just before the 1883 eruption. The volcano's summit seems as primed for landslide now as just before the 1883 eruption.

Because Augustine's 1883 avalanche occurred by chance during a falling low tide in a sparsely populated region, the effects of its tsunami on people were small. Even so, Davidson (1884) wrote of the first and largest wave at English Bay on 6 October 1883: "Fortunately it was low water, or all of the people at the settlement must inevitably have been lost." Were a large Augustinian debris avalanche - say the volume of West Island - to enter the sea during a rising high tide, a consequent tsunami to the modern populations in coastal areas of lower Cook Inlet would likely be larger and far more damaging than were the tsunami on 6 October 1883 . Tsunami are not just one inundation but typically a series. Three 1883 accounts mention several waves, even the lesser ones 4 to $6 \mathrm{~m}$ high. Were an Augustine-caused tsunami to occur in the future at high tide, a succession of tsunami waves along with a relentless current could sweep shorelines in lower Cook Inlet $4 \mathrm{~m}$ and more above normal high water.

\section{Hazards}

Hazards from Augustine Volcano to people about lower Cook Inlet have been a concern since the 1976 eruption began. A detailed draft hazards report in 1978 by David A. Johnston and others went unpublished after Johnston's death at Mount St. Helens in 1980 - though parts were incorporated into a hazards report by Kienle and Swanson $(1980,1985)$. A later nontechnical update summarizes possible hazards from Augustine Volcano (Waythomas and Waitt, 1998).

Most potentially lethal processes like falling cobble-sized particles, scorching pyroclastic flow or surge, or lahar are confined to the uninhabited island. The brief $700^{\circ} \mathrm{C}$ heat blast (as David Johnston inferred) at Burr Point hut during the 24 January 1976 surge would have maimed or killed there and to some distance offshore. During the 1968 eruption of Mayon volcano in the Philippines, a wind blast uprooted trees, then a heat surge torched upturned roots into charcoal and killed many animals and one human but left little or no deposit (Moore and Melson, 1969; J.G. Moore, written commun., 1977 [to D.A. Johnston] and 2000 [to R.B. Waitt]). And people died near the outer edge of the 18 May 1980 surge at Mount St. Helens where today more than a quarter century later little deposit remains to record the event. From Krakatau in 1883, scorching flows and surges swept lethally across the sea as far as $80 \mathrm{~km}$ (Carey and others, 1996; Winchester, 2003) where today there remains little or no deposit. At Mont Pelée, Martinique in 1902 such surges swept offshore across a few kilometers with enough energy and heat to ravage and capsize ships and to kill crew and passengers (Anderson and Flett, 1903; Macdonald, 1972; Scarth, 2002). At Monserrat in 1996 to 1998, surges ran down valleys to the coast and then more than a kilometer over the sea (Cole and others, 2002). Clearly the zone of safety from hot surge off an island volcano must be drawn some distance beyond the coastal limit of deposits from past events. At Augustine Island it should be some kilometers offshore of the north and northeast flanks where recent eruptions have focused activity.

The potentially most hazardous processes at greater distances from Augustine Island are airborne volcanic ash, and tsunami generated by debris avalanche. During the 1976 pumiceous tephra fall, angular rock fragments as large as $10 \mathrm{~cm}$ punctured a corrugated-steel roof on Augustine's coast $6 \mathrm{~km}$ from the vent. Falling lithic clasts could affect boats some distance offshore. But tephra both thins and fines sharply downwind (fig. 8). Ash from even a large Augustine eruption would be thinner than $5 \mathrm{~cm}$ on habited areas of Cook Inlet. Even wet it would be heavy enough to collapse only the flimsiest roofs.

The moderate eruptions of ash from Augustine in 1976 and 1986 were hazardous to aircraft and airports. At least five jet aircraft (two military, three commercial) encountered and were damaged by airborne ash of two separate plumes during the 1976 Augustine eruptions (Kienle and Shaw, 1979). During eruptions of Redoubt volcano (80 miles north of Augustine) in 1989-1990, five aircraft encountered airborne ash, including a large passenger airliner that for a time lost its engines (Casadevall, 1991, 1994b). Airborne ash has since become a recognized hazard to jet aircraft (Casadevall, 1992, 1994a; Casadevall and Krohn, 1995).

Effects and hazards by tsunami from Augustine are much debated. Some infer likely damage, others deny even the observed harbor waves of 6 October 1883, suggesting that future hazards from an Augustinian tsunami are no greater than by severe coastal storms. Tsunami researchers of NOAA's Alaska Tsunami Warning Center argue against this last notion (Thomas Sokolowski and Paul Whitmore, written commun., 1997):

... The danger from a 12-25 $\mathrm{m}$ wind wave cannot be compared directly to the danger of a 6- $m$ tsunami, [owing] to their different periods. The runup or inundation from even large storm waves like these is minimal, [owing] to their breaking nature. [But] a 6-m tsunami is a 6 m inundation along with a dangerous current. As an example, 6-m wind-generated waves along the southern California coast are not uncommon and are typically not damaging. The 0.8-m 1960 Chile tsunami, though, produced over \$1 million damage in L.A. harbor alone.

Indeed Nott $(1997,2000)$ calculates that for coastal boulder deposits, a storm wave would have to be 4 times the height of a tsunami to transport a given boulder - thus a boulder moved by a $6-\mathrm{m}$ tsunami would requires a $24-\mathrm{m}$ storm wave. The provisional hazard report for Augustine Volcano (Waythomas and Waitt, 1998) argues that because the debris avalanches enter shallow water they can't develop large, fast-moving sea waves. The logic is only theoretical. In practice, numerous shallow-water displacements have produced observed tsunami waves. A trifling landslide into shallow water off Vulcano in Italy in 1988 induced a small local tsunami, and a small landslide into shallow water on coastal Fatu Hiva in French Polynesia in 1999 spread a tsunami that 
ran up 3 to $7 \mathrm{~m}$ high into a nearby bay (Tinti and others, 1999; Okal and others, 2002). Larger historical examples are numerous (parts of table 4). By the field relations on Augustine Island and on distant coasts, by the tsunami observed in 1883 , and by the fact that along rocky coasts tsunami can leave only small and sporadic records, we looking outward from Augustine Island think that tsunami generated by future debris avalanches into the sea threaten distant mainland shores.

\section{Acknowledgments}

Jürgen Kienle introduced us to Augustine in 1986-1988, when our fieldwork began on this project. In the late 1960s through 1970s, Robert B. Forbes and Jürgen Kienle had collected many historical photographs and written accounts of past eruptions, materials that contribute to our understanding of historical eruptions and aid in illustrating this report. Begét's stratigraphic work on coastal exposures was mostly 1986-1988. Waitt's fieldwork for this report and map occurred 1988-1993, 1995, 1997, and 2002 (minor). We two coauthors had several days of joint fieldwork scattered over the period 1988-2002. Collaborating with or assisting Waitt in the field at various times were Jürgen Kienle, Hiroki Kamata, Robert G. McGimsey, Michael P. Doukas, Cynthia A. Gardner, and Christina A. Neal. Kienle contributed directly to the provisional version of this report and map (Waitt and Begét, 1996). Several colleagues aided our knowledge of Augustine or shared in field logistics: Michael Doukas, Jack Kleinman, Thomas L. Murray, John A. Power, Christopher J. Nye, and Samuel E. Swanson. Lee Siebert kindly sent a copy of George Davidson's official letter of 1884 that he found in the archives of the U.S. Coast and Geodetic Survey at Washington, D.C. Wes Hildreth supplied David Johnston's unpublished Augustine manuscript fragments of 1978-79 and copies of some of his Augustine fieldnotes.

After his Ph.D. thesis on Augustine's 1976 eruption, David A. Johnston began in summer 1978 investigating deposits of Augustine's historical eruptions, picking up where Detterman (1973) had left off. His 1978-79 fieldnotes and preliminary airphoto maps show deposits especially of 1976 that we remapped in 1988-94. Though we examined Johnston's materials mostly after our fieldwork ended, his careful notes and annotated airphotos from when 1976 deposits were still fresh and distinct - before the north flank considerably changed in the 1986 eruption - helped us distinguish between certain deposits of Augustine's 1935, 1963-64, and 1976 eruptions.

On the administrative front, the concept of a comprehensive Augustine map and report and early needs like fieldwork, new aerial photographs, and new topographic maps were encouraged and supported by Thomas P. Miller, Scientist-InCharge of Alaska Volcano Observatory. And so the project flourished in 1988-1993.

Since our fieldwork began on Augustine, nearly two decades have passed as we put finishing touches to this report in 2007-08. One by one, four of Augustine's earlier geologists have disappeared. Dave Johnston, who studied the petrology of Augustine's 1976 eruption, died far too young in Mount St. Helens' eruption on 18 May 1980. Bob Detterman of the USGS, maker of the island's first geologic maps, is gone. Jürgen Kienle, who began the modern instrumental investigations of Augustine is gone too. So is his University of Alaska mentor and former Alaskan State Geologist, Bob Forbes - some of whose early collected historical photographs of Augustine adorn this report. Three of these men shared a frightening experience on erupting Augustine in early February 1976. A helicopter crash and windstorm had stranded Forbes, Kienle, Johnston, and four others at Burr Point. They huddled by the shore for three days in a corrugated-steel research hut that Kienle and Forbes had recently built, but which in late January 1976 a hot Augustine surge had ripped into and scorched. When the storm abated the men were finally plucked off the island. Twelve hours later the volcano sent another hot flow down to the sea. In June 2002 we authors (Waitt and Begét) were leading an international field trip to Augustine Island when at Burr Point we found that winter's wind had at last toppled the rotting old hut. A couple hours later a Cessna flew oddly low and slow over the north coast. It was family mingling Bob Forbes's ashes among Augustine's bone-white pumice.

\section{References Cited}

Aida, Isamu, 1975, Numerical experiments of the tsunami associated with the collapse of Mt. Mayuyama in 1792: Zishin, v. 27, p. 149-460 (in Japanese with English abstract).

Alaska Commercial Company, 1883 [unpublished], Record books for English Bay Station: Fairbanks, University of Alaska Library Archives, Box 10 (May 15, 1883-July 1884).

Anders, A.M., 1999, Secondary volcanic hazards - dating and classification of the Spring Point landslide, Red River lahar, and Red River event deposit, Iliamna volcano, Cook Inlet, Alaska: Senior integrative exercise, Carleton College, Northfield, MN.

Anders, A.M., and Begét, J.E., 1999, Giant landslides and coeval tsunami in lower Cook Inlet, Alaska: Geological Society of America Abstracts with Programs, v. 31, no. 7., p. A-48

Anderson, T., and Flett, 1903, Report on the eruptions of the Soufrière in St. Vincent, and on a visit to Montagne Pelée in Martinique: Philosophical Transactions of the Royal Society of London, Ser. A, v. 200, p. 353-553.

Andrade, C., 1992, Tsunami generated forms in the Algarve barrier islands (South Portugal): Science of Tsunami Hazard, v. 10, p. 21-33. 
Beaglehole, J.C., ed., 1967, The voyage of the Resolution and Discovery 1776-1780 - The journals of Captain James Cook on his Voyages of Discovery: Hakluyt Society, Cambridge University Press, 718 p.

Becker, G.F., 1898, Reconnaissance of the gold fields of southern Alaska, with some notes on general geology: U.S. Geological Survey 18th Annual Report, pt. 3, p. 28-58.

Begét, J.E., and Gardner, C.A., 2004, New evidence of tsunami from Augustine Volcano, Alaska [abs.]: Eos, Transactions American Geophysical Union, v. 83, no. 47, p. F1465.

Begét, J.E., Gardner, C.A., and Davis, K., 2008, Volcanic tsunami and prehistoric cultural transitions in Cook Inlet, Alaska: Journal of Volcanology and Geothermal Research, v. 176, p. 377-386.

Begét, J.E., and Kienle, J., 1992, Cyclic formation of debris avalanches at Mount St. Augustine Volcano: Nature, v. 356, p. 701-704.

Begét, J.E., and Kowalik, 2006, Confirmation and calibration of computer modeling of tsunami produced by Augustine Volcano, Alaska: Science of Tsunami Hazards, v. 24, p. 257-266.

Begét, J.E., Stihler, S.D., and Stone, D.B., 1994, A 500-yearlong record of tephra falls from Redoubt Volcano and other volcanoes in upper Cook Inlet, Alaska: Journal of Volcanology and Geothermal Research, v. 62, p. 55-67.

Belousov, Alexander, and Belousova, Marina, 1996, Large scale landslides on active volcanoes in the 20th centuryexamples from the Kurile-Kamchatka region (Russia), in Senneset, Kaare, ed., Landslides: Rotterdam, A.A. Balkema, p. 953-957.

Beresford, W., 1968 [1789], A voyage round the world but more particularly to the north-west coast of America, performed in 1785, 1786, 1787, and 1788, by Capt. Geo. Dixon: New York, Da Capo Press.

Bjerrum, L., and Jørstad, F., 1968, Stability of rock slides in Norway: Norwegian Geotechnical Institute, Publication 79, p. $1-111$.

Blong, R.J., 1984, Volcanic hazards: Sidney, Academic Press, $427 \mathrm{p}$.

Bogoyavlenskaya, G.E., 1962, Agglomerate flow Bezymianny volcano: Bulletin Volcanologique, v. 24, p. 203-210.

Bondevik, S., Svendsen, J.I., Johnsen, G., Mangerud, J., and Kaland, P.E., 1997, The Storegga tsunami along the Norwegian coast, its age and runup: Boreas, v. 26, p. 29-53.

Bondevik, S., Mangerud, J., Dawson, S., Dawson, A., and Lohne, Ø, 2003, Record-breaking height for 8000-year-old tsunami in the North Atlantic: Eos, Transactions American Geophysical Union, v. 84, no. 31, p. 289, 293.
Bronk Ramsey, C., 1998, Probability and dating: Radiocarbon, v. 40 , no. 1 , p. $461-474$

Bronk Ramsey, C., 2000, Comment on "The use of Bayesian statistics for ${ }^{14} \mathrm{C}$ dates of chronologically ordered samples: a critical analysis": Radiocarbon, v. 42, no. 2, p. 199-202

Bronk Ramsey, C., 2001, Development of the radiocarbon calibration program OxCal: Radiocarbon, v. 43 no. $2 \mathrm{~A}$, p. 355-363.

Bryant, E.A., 2001, 2008, Tsunami-The underrated hazard: Cambridge, U.K., Cambridge University Press, 320 p.

Bryant, E.A. and Young, R.W., 1996, Bedrock-sculpting by tsunami, South Coast New South Wales, Australia: Journal of Geology, v. 104, p. 565-582.

Bryant, E.A., and Nott, J.F., 2001, Geological indicators of large tsunami in Australia: Natural Hazards, v. 24, p. 231-249.

Bryant, E.A., and Haslett, S.K., 2007, Catastrophic wave erosion and boulder transport in the Bristol Channel and Severn Estuary, UK - impact of tsunami?: Journal of Geology, v. 155, p. 253-269.

Bullard, F.M., 1976, Volcanoes of the earth: Austin, University of Texas Press, $579 \mathrm{p}$.

Buffler, R.T., 1976, Geologic map of south Augustine Island, lower Cook Inlet, Alaska: Alaska Department of Natural Resources, Division of Geology and Geophysical Surveys, Open-File Report AOF-96, 3 p. and map.

Carey, S., Sigurdsson, H., Mandeville, C., and Bronto, S., 1996, Pyroclastic flows and surges over waterCan example from the 1883 Krakatau eruption: Bulletin of Volcanology, v. 57, p. $493-511$.

Casadevall, T.J., ed., 1991, First International Symposium on Volcanic Ash and Avation Safety: U.S. Geological Survey Curcular 1065, $58 \mathrm{p}$.

Casadevall, T.J., 1992, Volcanic hazards and avation safety: FAA Aviation Safety Journal, v. 2, no. 3, p. 9-17.

Casadevall, T.J., 1994a, Volcanic ash and avation safety: U.S. Geological Survey Bulletin 2047, 450 p.

Casadevall, T.J., 1994b, The 1989-1990 eruption of Redoubt volcano, Alaska - impact on aircraft operations, in Miller, T.P., and Chouet, B.A., eds., The 1989-90 Eruption of Redoubt Volcano, Alaska : Journal of Volcanology and Geothermal Research, v. 62, p. 301-316.

Casadevall, T.J., and Krohn, M.D., 1995, Effects of the 1992 Crater Peak eruptions on airports and aviation operations in the United States and Canada, in Keith, T.E.C., ed., The 1992 eruptions of Crater Peak vent, Mount Spurr volcano, Alaska: U.S. Geological Survey Bulletin 2139, p. 205-220. 
Chow, V.T., 1959, Open-channel hydraulics: New York, McGraw-Hill, 680 p.

Coats, R.R., 1950, Volcanic activity in the Aleutian arc: U.S. Geological Survey Bulletin 974-B, p. 35-48 and 2 plates.

Cole, P.D., Calder, E.S., Sparks, R.S.J., Clarke, A.B., Druitt, T.H., Young, S.R., Herd, R.A., Harford, C.L., and Norton, G.E., 2002, Deposits from dome-collapse and fountain-collapse pyroclastic flows at Soufrière Hills Volcano, Monserrat: Geological Society of London Memoir 21, p. 231-262.

Cook, L., and Norris, F., 1998, A Stern and Rock-Bound Coast_Kenai Fjords National Park Historic Resource Study: Anchorage, National Park Service, Alaska Support Office, 429 p. Also published online: http://www.nps.gov history/history/online_books/kefj/hrs/hrs.htm.

Cooke, R.J.S., 1981, Eruptive history of the volcano Ritter Island, in Johnson, R.W., ed., Cooke-Ravian volume of volcanological papers: Geological Survey of Papua New Guinea, Memoir 10, p. 115-123.

Cordeiro, F. J. B., 1910, The volcanoes of Alaska: Appalachia, v. 12 , p. $130-135$.

Cotton, C.A., 1944, Volcanoes as landscape forms: Christchurch, New Zealand, Whitcombe \& Tombs, 416 p.

Crandell, D.R., and Mullineaux, D.R., 1978, Potential hazards from future eruptions of Mount St. Helens volcano, Washington: U.S. Geological Survey Bulletin 1383-C, 26 p., 2 plates.

Crisp, J.A., 1984, Rates of magma emplacement and volcanic output: Journal of Volcanology and Geothermal Research, v. 20, p. 177-211.

Criswell, C.W., 1987, Chronology and pyroclastic stratigraphy of the May 18, 1980, eruption of Mount St. Helens, Washington: Journal of Geophysical Research, v. 92, p. 10237-10266.

Daley, E.E., 1986, Petrology, geochemistry, and the evolution of magmas from Augustine Volcano, Alaska: Fairbanks, University of Alaska, M.S. thesis, 69 p.

Dall, W.H., 1884, A new volcano island in Alaska: Science: v. 3, no. 51, p. 89-93.

Dall, W.H., 1918, Reminiscences of Alaskan volcanoes: The Scientific Monthly, v. 7, no. 1, p. 80-90.

Davidson, G., 1884, Notes on the eruption of Mount St. Augustine, Alaska, October 6, 1883: Science, v. 3, no. 54, p. 186-189.

Davies, J., Sykes, L., House, L., and Jacob, K., 1981, Shumagin seismic gap, Alaska Peninsula - history of great earthquakes, tectonic setting, and evidence for high seismic potential: Journal of Geophysical Research, v. 86, p. 3821-3855.
Denlinger, R.P., and Iverson, R.M., 2001, Flow of variably fluidized granular masses across three-dimensional terrain; 2, numerical predictions and experimental tests: Journal of Geophyical Research, v. 106, p. 553-566.

Detterman, R.L., 1968, Recent volcanic activity on Augustine Island, Alaska: U.S. Geological Survey Professional Paper 600-C, p. 126-129.

Detterman, R.L., 1973, Geologic map of the Iliamna BB2 quadrangle, Augustine Island, Alaska: U.S. Geological Survey Geologic Quadrangle Map GQ-1068, scale 1:63,360.

Detterman, R.L., and Hartsock, J.K., 1966, Geology of the Iniskin-Tuxedni region, Alaska: U.S. Geological Survey Professional Paper 512, 78 p. and geologic map at scale $1: 63,360$.

Detterman, R.L., and Jones, D.L., 1974, Mesozoic fossils from Augustine Island, Cook Inlet, Alaska: American Association of Petroleum Geologists Bulletin, v. 58, p. 868-870.

Detterman, R.L., and Reed, B.L., 1964, Preliminary map of the geology of the Iliamna quadrangle, Alaska: U.S. Geological Survey Miscellaneous Investigations Map I-407, scale $1: 250,000$.

Doroshin, Petr, 1870, Some volcanoes, their eruptions, and earthquakes in the former Russian holdings in America: Verhandlungen der Russisch-Kaiserlichen Mineralogischen Gesellschaft zu St. Petersburg, Zweite Serie, Fünfter Rand, p. 25-44 (in Russian).

Druitt, T.H., 1992, Emplacement of the 18 May 1980 lateral blast deposit ENE of Mount St. Helens, Washington: Bulletin of Volcanology, v. 54, p. 554-572.

Dzurisin, D., Vallance, J.W., Gerlach, T.M., Moran, S.C., and Malone, S.D., 2005, Mount St. Helens reawakens: Eos, Transactions American Geophysical Union, v. 86, no. 3, p. 25,29 .

Eisbacher, G.H., and Clague, J.J., 1984, Destructive mass movements in high mountains - hazard and management: Geological Survey of Canada Paper 84-16, 230 p.

Evans, S.G., 1992, Landslide and river damming events associated with the Plinth Peak volcanic eruption, southwest British Columbia: Vancouver, B.C., BiTech Publishing, Geotechnical and Natural Hazards, p. 405-412.

Evans, S.G., Hungr, O., and Enegren, E.G., 1994, The Avalanche Lake rock avalanche, Mackenzie Mountains, Northwest Territories, Canada-description, dating, and dynamics: Canadian Geotechnical Journal, v. 31, p. 749-768.

Ewing, M., and Press, F., 1955, Tide-gage disturbances from the great eruption of Krakatoa: Transactions American Geophysical Union, v. 36, p. 53-60. 
Folk, R.L., 1954, The distinction between grain size and mineral composition in sedimentary-rock nomenclature: Journal of Geology, v. 62, p. 344-359.

Folk, R.L., 1974, 1980, Petrology of sedimentary rocks [course syllabus for University of Texas sedimentology]: Austin, Texas, Hemphill Publishing Co., 186 p.

Forbes, R.B., and Kienle, J., 1971, Mount Saint Augustinerestless volcano: Pacific Search, December 1971, p. 3-4.

Francis, P.W., 1985, The origin of the 1883 Krakatau tsunami: Journal of Volcanology and Geothermal Research, v. 25, p. 349-363.

Fritz, H.M., 2002, Initial phase of landslide generated impulse waves: Versuchsanstalt für Wasserbau, Hydrologie und Glaziologie, Eidgenössischen Technische Hochschule, Mitteilungen $178,342 \mathrm{p}$.

Frolich, C., Hornbach, M.J., Taylor, F.W., Shen, C.-C., Moala, A., Martin, A.E., and Kruger, J., 2009, Huge erratic boulders in Tonga deposited by a prehistoric tsunami: Geology, v. 37, p. 131-134.

Glicken, H., 1991, Sedimentary architecture of large volcanicdebris avalanches, in Fisher, R.V. and Smith, G.A., Sedimentation in volcanic settings: SEPM Special Publication 45, p. 99-106.

Glicken, H., 1996, Rockslide-debris avalanche of May 18, 1980, Mount St. Helens volcano, Washington: U.S. Geological Survey Open-File Report 96-677, 90 p.

Glicken, H., 1998, Rockslide-debris avalanche of May 18, 1980, Mount St. Helens volcano, Washington: Bulletin of the Geological Survey of Japan, v. 49, p. 55-106 and 10 map plates.

Gorshkov, G.S., 1959, Gigantic eruption of the volcano Bezymianny: Bulletin Volcanologique, v. 21, p. 77-109.

Griggs, R.F., 1920, The great Mageik landslide: Ohio Journal of Science, v. 20, p. 325-354.

Griggs, R.F., 1922, The Valley of Ten Thousand Smokes: The National Geographic Society, 340 p.

Hamilton, T.D., and Thorson, R.M., 1983, The Cordilleran ice sheet in Alaska, in Porter, S.C., ed., vol. 1, The late Pleistocene, in Wright, H.E., Jr., Late Quaternary Environments of the United States: Minneapolis, Univ. of Minnesota Press, p. 38-52.

Harkrider, David, and Press, Frank, 1967, The Krakatoa airsea waves - an example of pulse propogation in coupled systems: Journal of Geophysical Research, Astronomy Section, v. 13, p. 149-159.

Harrison, J.V., and Falcon, N.L., 1937, The Saidmarreh landslip, southwest Iran: Geographical Journal, v. 89, p. 42-47.
Harrison, J.V., and Falcon, N.L., 1938, An ancient landslip at Saidmarreh in southwestern Iran: Journal of Geology, v. 46, p. 296-309.

Haslett, S.K., and Bryant, E.A., 2005, The AD 1607 coastal flood in the Bristol Channel and Severn Estuary-historical records from Devon and Cornwall (UK): Archeology of Severn Estuary, v. 15, p. 163-167.

Hsü, K.J., 1975, Catastrophic debris streams (sturzstroms) generated by rockfalls: Geological Society of America Bulletin, v. 86, p. $129-140$.

Iverson, R.M., LaHusen, R.G., Major, J.J., and Zimmerman, C.L., 1994, Debris flow against obstacles and bendsdynamics and deposits [abs.]: Eos, Transactions American Geophysical Union, v. 75, no. 44 supplement, p. 274.

Iverson, R.M., and Denlinger, 2001, Flow of variably fluidized granular masses across three-dimensional terrain; 1. Coulomb mixture theory: Journal of Geophyical Research, v. 106, p. 537-552.

Jacobsen, J.A., 1977, Alaskan voyage 1881-1883-An expedition to the northwest coast of America (translated by E. Gunther): University of Chicago Press, 266 p.

Johnson, R.W., 1987, Large-scale volcanic cone collapse-the 1888 slope failure of Ritter volcano: Bulletin of Volcanology, v. 49, p. 669-679.

Johnston, D.A., 1977, The 1976 eruption of Augustine Volcano, Alaska, and evaluation of hazards for future eruptions: Geological Society of America, Abstracts with Programs, v. 9, p. 442-443.

Johnston, D.A., 1978, Volatiles, magma mixing, and the mechanism of eruption of Augustine Volcano, Alaska: Seattle, University of Washington Ph.D. dissertation, 177 p.

Johnston, D.A., 1979, Onset of volcanism at Augustine Volcano, lower Cook Inlet, Alaska: U.S. Geological Survey Circular 804-B, p. 78-80.

Johnston, D.A., and Detterman, R.L., 1979, Revision of the recent eruption history of Augustine Volcano — elimination of the "1902 eruption”: U.S. Geological Survey Circular 804-B, p. 80-83.

Jones, B., and Hunter, I.G., 1992, Very large boulders on the coast of Grand Cayman - the effect of giant waves on rocky coastlines: Journal of Coastal Research, v. 8, p. 768-774.

Jones, D.L., 1963, Upper Cretaceous (Campanian and Maestrichtian) ammonites from southern Alaska: U.S. Geological Survey Professional Paper 432, 53 p.

Jones. D.L., and Clark, S.H. B., 1973, Upper Cretaceous (Maestrichtian) fossils from the Kenai-Chugach Mountains, Kodiak and Shumagin Islands, southern Alaska: U.S. Geological Survey Journal of Research, v. 1, 125-136. 
Jones, D.L., and Detterman, R.L., 1966, Cretaceous stratigraphy of the Kamishak Hills, Alaska Peninsula: U.S. Geological Survey Professional Paper 550-D, p. 53-58.

Jørstad, F., 1968, Waves generated by landslides in Norwegian fjords and lakes: Norwegian Geotechnical Institute, Publication 79, $20 \mathrm{p}$.

Kamata, H., and Waitt, R.B., 1989, Stratigraphy, chronology, and style of the 1976 pyroclastic eruption of Augustine Volcano, Alaska [Abs.], in Continental Magmatism Abstracts: New Mexico Bureau of Mines and Mineral Resources Bulletin 131, p. 146.

Kamata, H., Johnson, D.A., and Waitt, R.B., 1991, Stratigraphy, chronology, and character of the 1976 pyroclastic eruption of Augustine Volcano, Alaska: Bulletin of Volcanology, v. 53, p. 407-419.

Karlstrom, T.N.V., 1964, Quaternary geology of the Kenai lowland and glacial history of the Cook Inlet region, Alaska: U.S.Geological Survey Professional Paper 443, 69 p. and 7 plates.

Kawana, T., and Nakata, T., 1994, Timing of late Holocene tsunami originating around the Southern Ryulyu Islands, Japan, deduced from coralline tsunami deposits: Japanese Journal of Geography, v. 103, p. 352-376.

Kawata, Y., Borrero, J , Davies, H., Imamura, F., Letz, H., Nott, J., and Synolakis, C., 1999, Tsunami in Papua New Guinea was as intense as first thought: Eos, Transactions American Geophysical Union, v. 80, p. 101, 104-105.

Keller, A.S., and Reiser, H.N., 1961, Geology of the Mount Katmai area, Alaska: U.S. Geological Survey Bulletin 1058, p. 261-298.

Keskinen, M.J. and Begét, J.E., 2006, Proximal tsunami deposits produced during the 1883 eruption of Augustine Volcano, Alaska [Abs.]: Eos, Transactions American Geophysical Union, v. 87, no. 52, fall meeting supplement, Abstract PP43B-1245.

Kienle, J., 1986, Augustine Volcano_-awake again?: Eos, Transactions American Geophysical Union, v. 67, p. $172-173$.

Kienle, J., Davies, J.N., Miller, T.P., and Yount, M.E., 1986, 1986 eruption of Augustine Volcano — public safety response by Alaskan volcanologists: Eos, Transactions American Geophysical Union, v. 67, no 29, p. 580-582.

Kienle, J., and Forbes, R.B., 1976, Augustine-evolution of a volcano: Geophysical Institute, Annual Report 1975-1976, p. $26-48$.
Kienle, J. and Shaw, G.E., 1979, Plume dynamics, thermal energy, and long-distance transport of vulcanian eruption clouds from Augustine Volcano, Alaska: Journal of Volcanology and Geothermal Research, v. 6, p. 139-164.

Kienle, J., and Swanson, S.E., 1980, 1985, Volcanic hazards from future eruptions of Augustine Volcano, Alaska: Fairbanks, University of Alaska Geophysical Institute, document R-275, 126 p. and map [reprinted nearly verbatim 1985].

Kienle, J., and Swanson, S.E., 1983a, Volcanism in the eastern Aleutian arc - late Quaternary and Holocene centers, tectonic setting and petrology: Journal of Volcanology and Geothermal Research, v. 17, p. 393-432.

Kienle, J., and Swanson, S.E., 1983b, The hazards of Augustine: The Northern Engineer, v. 15, no. 3, p. 10-37.

Kienle, J., Kowalik, Z., and Murty, T.S., 1987, Tsunami generated by eruptions from Mount St. Augustine Volcano, Alaska: Science, v. 236, p. 1442-1447.

Kiersch, G.A., 1964, Vaiont Reservoir disaster: Civil Engineering, March 1964 issue, p. 32-39.

Klein, Janet, 1981, A history of Kachemak Bay-the county, the communities: Homer, Alaska, Homer Society of Natural History, $115 \mathrm{p}$.

Kowalik, Z., and Murty, T.S., 1989, On some future tsunami in the Pacific Ocean: Natural Hazards, v. 1, p. 349-369.

Krafft, Maurice, producer, 1991, Understanding Volcanic Hazards [video]: International Association of Volcanology and Chemistry of the Earth's Interior, $25 \mathrm{~min}$.

Kulikov, E.A., Rabinovich, A.B., Thompson, R.E., and Bornhold, B.D., 1996, The landslide tsunami of November 3, 1994, Skagway harbor, Alaska: Journal of Geophysical Research, v. 101C, p. 6609-6615.

Lamb, W.K., ed., 1984, George Vancouver, A voyage of discovery to the north Pacific Ocean and round the world 1791-1795, v. 4: London, Hakluyt Society, no. 166.

Lander, J.F., 1996, Alaskan tsunami 1737-1996: National Oceanographic and Atmospheric Administration (NOAA), National Geophysical Data Center (Boulder, Co.), Geophysical Research Document 31, 195 p.

Lander, J.F., and Lockridge, P.A., 1989, United States tsunami (including United States Possessions) 1690-1988: U.S. Department of Commerce, National Oceanographic and Atmospheric Administration (NOAA), National Geophysical Data Center, Publication 41-2, 265 p. 
Lander, J.F., Lockridge, P.A., and Kozuch, M.J., 1993, Tsunami affecting West Coast of the United States 1806-1992: U.S. Department of Commerce, National Oceanographic and Atmospheric Administration (NOAA), National Geophysical Data Center, Document KGRD-29, 242 p.

Latter, J.H., 1981, Tsunami of volcanic origin - summary of causes, with particular reference to Krakatoa, 1883: Bulletin Volcanologique, v. 44, p. 467-490.

LeBas, M.J., and Streckeisen, R.W., 1991, the IUGS systematics of igneous rocks: Journal of the Geological Society of London, v. 148, p. 825-833.

Macdonald, G.A., 1972, Volcanoes: Englewood Cliffs, N.J., Prentice-Hall, $510 \mathrm{p}$.

Magoon, L.B., Adkison, W.L., and Egbert, R.M., 1976, Map showing geology, wildcat wells, Tertiary plant fossil localities, K-Ar age dates, and petroleum operations, Cook Inlet area, Alaska: U.S. Geological Survey Miscellaneous Investitgations Series, Map I-1019.

Mastin, L.G., 2001, Eject!-A simple calculator of ballistic trajectories for blocks ejected during volcanic eruptions: U.S. Geological Survey Open-File Report 01-45.

McCullough, D.S., 1966, Slide-induced waves, seiching, and ground fracture caused by the earthquake of March 27, 1964 at Kenai Lake, Alaska: U.S. Geological Survey Professional Paper 543-A, 41 p.

McDougall, S.D., and Hungr, O., 2003, Objectives for the development of an integrated three-dimensional continuum model for the analysis of landslide runout, in Rickerman and Chen, eds., Debris-flow hazards mitigationCmechanics, prediction, and assessment: Rotterdam, Millpress, p. 481-490.

McGimsey, R.G., Neal, C.A., and Girina, O., 2003, Volcanic activity in Alaska and Kamchatka - summary of events and response of the Alaska Volcano Observatory: U.S. Geological Survey Open-File Report 03-423.

Miller, D.J., 1960, Giant waves in Lituya Bay, Alaska: U.S. Geological Survey Professional Paper 354-C, 86 p.

Moore, G.W., and Moore, J.G., 1984, Deposits from a giant wave on the island of Lanai, Hawaii: Science, v. 226, p. 1312-1315.

Moore, J.G., Kazuaki, N., and Alcaraz,, A., 1966, The 1965 eruption of Taal volcano: Science, v. 151, p. 955-960.

Moore, J.G., and Melson, W.G., 1969, Nueés ardentes of the 1968 eruption of Mayon Volcano, Philippines: Bulletin Volcanologique, v. 33, p. 600-620.
Moore, J.G., and Sisson, T.W., 1981, Deposits and effects of the May 18 pyroclastic surge, in Lipman, P.W. and Mullineaux, D.R., eds., The 1980 Eruptions of Mount St. Helens, Washington: U.S. Geological Survey Professional Paper 1250, p. 421-438.

Moore, J.G., Normark, W.R., and Holcomb, R.T., 1994, Giant Hawaiian underwater landslides: Science, v. 264, p. 46-47.

Myers, B., and Brantley, S.R., 1995, Hazardous phenomena at volcanoes (Volcano Hazards Fact Sheet): U.S. Geological Survey Open-File Report 95-231.

Myers, E.P., and Baptista, A.M., 1995, Finite element modeling of the July 12, 1993 Hokkaido Nansei-Oki tsunami: Pure and Applied Geophysics, v. 144, p. 769-801.

Nishimura, Yuichi, and Satake, Kenji, 1993, Numerical computations of tsunami from the past and future eruptions of Komagatake volcano, Hokkaido, Japan: Proceedings of the IUGG/OIC international tsunami symposium: International Union of Geodesy and Geophysics, p. 573-583.

Nott, J.F., 1997, Extremely high-energy wave deposits inside the Great Barrier Reef, Australia — determining cause, tsunami or tropical cyclone: Marine Geology, v. 141, p. 193-207.

Nott, J.F., 2000, Records of prehistoric tsunami from boulder deposits - evidence from Australia: Science of Tsunami Hazards, v. 18, p. 3-14.

Nott, J.F., 2003, Waves, clastal boulder deposits, and the importance of the pre-transport setting: Earth and Planetary Science Letters, v. 210, p. 269-276.

Nott, J., and Bryant, E., 2003, Extreme marine inundations (tsunami?) of coastal Western Australia: Journal of Geology, v. 111, p. 691-706.

Oberlander, T., 1965, The Zagros streams: Syracuse University Press, Syracuse Geographical Series, no. 1, 168 p.

Okal, E.A., Fryer, G.J., Borrero, J.C., and Ruscher, C., 2002, The landslide and local tsunami of 13 September 1999 on Fatu Hiva (Marquesas Islands; French Polynesia): Bulletin de la Societe Geologique de France, v. 173, p. 359-367.

Orth, D.J.,1967, Dictionary of Alaska place names: U.S. Geological Survey Professional Paper 567.

Padang, Neumann van, 1959, Changes in the top of Mount Ruang (Indonesia): Geologie En Mijnbouw, v. 21, p. 113-118.

Pierson, T.C., and Janda, R.J., 1994, Volcanic mixed avalanches - a distinct eruption-triggered mass flow process as snow-clad volcanoes: Geological Society of America Bulletin, v. 106, p. 1351-1358. 
Pierson, T.C., Scott, K.M., and Wood, N.J., in press, Volcanohydrologic hazards - lahars, debris avalanches, and related phenomena: Cambridge University Press.

Pierson, T.C., and Waitt, R.B., 1999, Dome-collapse rockslide and multiple sediment-water flows generated by a small explosive eruption on February 2-3, 1983, in Pierson, T.C., ed., Hydrologic consequences of hot-rock/snowpack interactions at Mount St. Helens volcano, Washington, 1982-84: U.S. Geological Survey Professional Paper 1586, p. 53-68.

Plafker, George, 1969, Tectonics of the March 27, 1964, Alaska Earthquake: U.S. Geological Survey Professional Paper 543-I, 74 p. and 2 plates.

Plafker, G., Greene, H.G., Maher, N., and Synolakis, C., 2000, Mechanism of the November 3, 1994, submarine landslide and associated landslide-generated tsunami at Skagway, Alaska: Eos, Transactions American Geophysical Union, v. 81, no. 48 , p. F-759.

Plafker, George, and Kachadoorian, Ruben, 1966, Geologic effects of the march 1964 earthquake and associated seismic sea waves on Kodiak and nearby islands, Alaska: U.S. Geological Survey Professional Paper 543-D, 46 p. and 4 plates.

Plafker, G., Kachadoorian, R., Eckel, E.B., and Mayo, L.R., 1969, Effects of the earthquake of March 27, 1964 on various communities: U.S. Geological Survey Professional Paper 542-G, $50 \mathrm{p}$. and 2 plates.

Power, J.A., 1988, Seismicity associated with the 1986 eruption of Augustine Volcano, Alaska: University of Alaska, Fairbanks, M.S. thesis, 142 p.

Power, J.A., Nye, C.J., Coombs, M.L., Wessels, R.L., Cervelli, P.F., Dehn, J., Wallace, K.L., Freymueller, J.T., and Doukas, M.P., 2006, The reawakening of Alaska's Augustine Volcano: Eos, Transactions of American Geophysical Union, v. 87, p. $373,377$.

Powers, M.C., 1953, A new roundness scale for sedimentary particles: Journal of Sedimentary Petrology, v. 23, p. 117-119.

Reeder, J.W., and Lahr, J.C., 1987, Seismological aspects of the 1976 eruptions of Augustine Volcano, Alaska: U.S. Geological Survey Bulletin 1768, 32 p.

Riehle, J.R., Waitt, R.B., Meyer, C.E., and Calk, L.C., 1998, Age of formation of Kaguyak Caldera, eastern Aleutian arc, Alaska, estimated by tephrochronology: U.S. Geological Survey Professional Paper 1595, p. 161-168.

Roman, D.C., Cashman, C.V., Gardner, C.A., Wallace, P.J., and Donovan, J.J., 2006, Storage and interaction of compositionally heterogeneous magmas from the 1986 eruption of Augustine Volcano, Alaska: Bulletin of Volcanology, v. 68, p. 240-254.
Russell, I.C., 1910, Volcanoes of North America: London, The Macmillan Company, 346 p.

Sarna-Wojcicki, A.M., Shipley, S., Waitt, R.B., Dzurisin, D., and Wood, S.H., 1981, Areal distribution, thickness, mass, volume, and grain size of air-fall ash from the six magmatic eruptions of 1980, in Lipman, P.W. and Mullineaux, D.R., eds., The 1980 eruptions of Mount St. Helens, Washington: U.S. Geological Survey Professional Paper 1250, p. 577-600.

Satake, K., and Tanioka, Y., 1994, How well can we predict tsunami run-up heights? [abs.]: Transactions American Geophysical Union, v. 75, no. 44 Supplement, p. 356.

Savage, S.B., and Hutter, K., 1989, The motion of a finite mass of granular material down a rough incline: Journal of Fluid Mechanics, v. 199, p. 177-215.

Savage, S.B., and Hutter, K., 1991, The dynamics of avalanches of granular materials from initiation to runout; part I, analysis: Acta Mechanica, v. 86, p. 201-223.

Scarth, Alwyn, 2002, La Catastrophe-the eruption of Mount Pelée, the worst volcanic disaster of the 20th century: Oxford University Press, 246 p.

Scheffers, A., 2002, Paleotsunami in the Caribbean-field evidences and datings from Aruba, Curaçao, and Bonaire: Essener Geographische Arbeiten 33.

Schmid, R., 1981, Descriptive nomenclature and classification of pyroclastic deposits and fragments - recommendations of the IUGS Subcommission on the systematics of igneous rocks: Geology, v. 9, p. 41-43.

Sharpe, C.F.S., 1938, Landslides and related phenomena: New York, Columbia University Press, 137 p.

Siebert, L., 1984, Large volcanic debris avalanches - characteristics of source areas, deposits, and associated eruptions: Journal of Volcanology and Geothermal Research, v. 22, p. 163-197.

Siebert, L., 1992, Threats from debris avalanches: Nature, v. 356, p. 658-659.

Siebert, L., Glicken, H., and Ui, T., 1987, Volcanic hazards from Bezymianny- and Bandai-type eruptions: Bulletin of Volcanology, v. 49, p. 435-459.

Siebert, L., Glicken, H., and Kienle, J., 1989, Debris avalanches and lateral blasts at Mount St. Augustine Volcano, Alaska: National Geographic Review, v. 5, p. 232-249.

Siebert, L., Begét, J.E., and Glicken, H., 1995, The 1883 and late-prehistoric eruptions of Augustine Volcano, Alaska: Journal of Volcanology and Geothermal Research, v. 66, p. 367-395. 
Sigurdsson, H., Carey, S., and Mandeville, C., 1991, Krakatau: National Geographic Research and Exploration, v. 7, p. 310-327.

Silver, E., Day, S., Ward, S., Hoffmann, G., Llanes, P., Lyons, A., Driscoll, N., Perembo, R., John, S., Saunders, S., Taranu, F., Anton, L., Abiari, I., Applegate, B., Engels, J., Smith, J., and Tagliodes, J., 2005, Island arc debris avalanches and tsunami generation: Eos, Transactions American Geophysical Union, v. 86, p. 485, 489.

Simkin, Tom, and Fiske, R.S., 1983, Krakatau 1883-the volcanic eruption and its effects: Washington, D.C., Smithsonian Institution Press, 464 p.

Slingerland, R.L., and Voight, B., 1979, Occurrences, properties, and predictive models of landslide-generated water waves, in Voight, B., ed., Rockslides and Avalanches, 2, Engineering sites: Amsterdam, Elsevier, p. 317-397.

Sobel, Dava, 1995, Longitude: New York, Walker and Co., 184p.

Solonenko, V.P., 1977, Landslides and collapses in seismic zones and their prediction: Bulletin of the International Association of Engineering Geology: v. 15, p. 4-8.

Soloviev, S.L., and Go, Ch.N., 1984, Catalogue of tsunami of the western shore of the Pacific Ocean [translated from Russian]: Ottawa, Ontario, National Research Council, Canadian Translation of Fisheries and Aquatic Sciences no. 5077, 447 p.

Sousa, J., and Voight, B., 1995, Multiple-pulsed debris avalanche emplacement at Mount St. Helens in 1980 evidence from numerical continuum flow simulations: Journal of Volcanology and Geothermal Research, v. 66, p. 227-250.

Stasiuk, M.V., Russell, J.K., and Hickson, C.J., 1996, Distribution, nature, and origins of the $2400 \mathrm{BP}$ eruption products of Mount Meager, British Columbia_linkages between magma chemistry and eruption behaviour: Geological Survey of Canada Bulletin 486, 27 p. and map at 1:20,000 scale.

Stuiver, Minze, 1982, A high-precision calibration of the AD radiocarbon time scale: Radiocarbon, v. 24, p. 1-26.

Stuiver, M., and Pearson, G.W., 1993, High-precision bidecadal calibration of the radiocarbon time scale, AD 1950-500 BC and 2500-6000 BC: Radiocarbon, v. 35, p. $1-23$.

Stuiver, M., and Reimer, P.J., 1993, Extended ${ }^{14} \mathrm{C}$ data base and revised CALIB $3.0{ }^{14} \mathrm{C}$ calibration program: Radiocarbon, v. 35, p. 215-230.

Stuiver, M., Reimer, P.J., and Braziunas, T.F., 1998, High-precision radiocarbon age calibration for terrestrial and marine samples: Radiocarbon, v. 40, p. 1127-1151.
Suiver, M., Reimer, P.J., and Reimer, R., 2005, CALIB Manual: http://calib.qub.ac.uk/calib/, last accessed 10 January 2009].

Swanson, S.E., and Kienle, J., 1988, The 1986 eruption of Mount St. Augustine - field test of a hazard evaluation: Journal of Geophysical Research, v. 93, p. 4500-4520.

Synolakis, C., Imamura, F., Tsuji, Y., Matsutomi, H., Tinti, S., Cook, B., Chandra, Y.P., and Usman, M., 1995, Damage, conditions of East Java tsunami of 1994 analyzed: Eos, Transactions American Geophysical Union, v. 26, p. 257, 261-262.

Tappin, D.R., Matsumoto, T., Watts, P., Satake, K., McMurty, G.M., Matsuyama, M., Lus, W., Iwabuchi, Y., Yeh, H., Matsumotu, Y., Nakamura, M., Mahoi, M., Hill, P., Crook, K., Anton, L., and Walsh, J.P., 1999, Sediment slump likely caused 1998 Papua New Guinea tsunami: Eos, Transactions American Geophysical Union, v. 80, no. 30, p. $329,334,340$.

Tinti, S., Bortolucci, E., and Armigliato, A., 1999, Numerical simulation of the landslide-induced tsunami of 1998 on Vulcano Island, Italy: Bulletin of Volcanology, v. 61, p. 121-137.

Tinti, S., Manucci, A., Pagnoni, G., Armigliato, A., and Zaniboni, F., 2005, The $30^{\text {th }}$ December 2002 tsunami in Stromboli-sequence of the events reconstructed from the eyewitness accounts: Natural Hazards and Earth System Sciences, v. 5, p. 763-775.

Tinti, S., Pagnoni, G., and Zaniboni, F., 2005, The landslides and tsunami of the $30^{\text {th }}$ of December 2002 in Stromboli analyzed through numerical simulations: Bulletin of Volcanology, v. 68, p. 462-479.

Thornbury, W.D., 1954, Geomorphology: New York, John Wiley \& Sons, 594 p.

Troshina, E.N., 1996, Tsunami waves generated by Mt. St. Augustine Volcano, Alaska: Fairbanks, University of Alaska M.S. thesis, $84 \mathrm{p}$.

Ui, T., Yamamoto, H., and Suzuki-Kamata, K., 1986, Characterization of debris avalanche deposits in Japan: Journal of Volcanology and Geothermal Research, v. 29, p. 231-243.

Voight, B., 1981, Time scale for the first moments of the May 18 eruption, in Lipman, P.W. and Mullineaux, D.R., eds., The 1980 eruptions of Mount St. Helens, Washington: U.S. Geological Survey Professional Paper 1250, p. 69-86.

Voight, B., Glicken, H., Janda, R.J., and Douglass, P.M., 1981, Catastrophic rockslide avalanche of May 18, in Lipman, P.W. and Mullineaux, D.R., eds., The 1980 eruptions of Mount St. Helens, Washington: U.S. Geological Survey Professional Paper 1250, p. 347-377. 
Voight, B., Janda, R.J., Glicken, H., and Douglass, P.M., 1983, Nature and mechanics of the Mount St. Helens rockslide avalanche of 18 May 1980: Geotechnique, v. 33, p. 243-273.

Waitt, R.B., 1981, Devastating pyroclastic density flow and attendant air fall of May 18 - stratigraphy and sedimentology of deposits, in Lipman, P.W. and Mullineaux, D.R., eds., The 1980 Eruptions of Mount St. Helens, Washington: U.S. Geological Survey Professional Paper 1250, p. 439-458.

Waitt, R.B., 1989, Swift snowmelt and floods (lahars) caused by great pyroclastic surge at Mount St. Helens volcano, Washington, 18 May 1980: Bulletin of Volcanology, v. 52, p. $138-157$.

Waitt, R.B., 1995, Hybrid wet flows formed by hot pyroclasts interacting with snow during the 1992 eruptions of Crater Peak, Mount Spurr volcano, Alaska: U.S. Geological Survey Bulletin 2139, p. 107-118.

Waitt, R.B., 2002, Great Holocene floods along Jokulsá á Fjöllum, north Iceland, in Flood and megaflood processes: International Association of Sedimentologists, Special Publication 32, p. 37-51.

Waitt, R.B., Pierson, T.C., MacLeod, N.S., Janda, R.J., Voight, B., and Holcomb, R.T., 1983, Eruption-triggered avalanche, flood, and lahar at Mount St. Helens - effects of winter snowpack: Science, v. 221, p. 1394-1397.

Waitt, R.B., and Pierson, T.C., 1994, The 1980 (mostly) and earlier explosive eruptions of Mount St. Helens volcano, in Swanson, D.A., and Haugerud, R.A., eds., Geologic field trips in the Pacific Northwest: Department of Geological Sciences, University of Washington, v. 2, Chapter 2-I, 37 p.

Waitt, R.B., Gardner, C.A., Pierson, T.C., Major, J.J., and Neal, C.A., 1994, Unusual ice diamicts emplaced during 15 December 1989 eruption of Redoubt Volcano, Alaska: Journal of Volcanology and Geothermal Research, v. 62, p. 409-428.

Waitt, R.B., Mastin, L.G., and Miller, T.P., 1995, Ballistic showers during Crater Peak (Mt. Spurr) eruptions, summer 1992, in Keith, T.E.C., ed., The 1992 eruptions of Crater Peak at Mount Spurr volcano, Alaska: U.S. Geological Survey Bulletin, p. 89-106.

Waitt, R.B., and Begét, J.E., with contributions by Juergen Kienle, 1996, Provisional geologic map of Augustine Volcano, Alaska: U.S. Geological Survey Open-File Report 96-516, 44 p. and map at 1:25,000 scale.
Ward, S.N., and Day, S., 2003, Ritter Island volcano-lateral collapse and the tsunami of 1888: Geophysical Journal International, v. 154, p. 891-902.

Waythomas, C.F., 1996, Volcanigenic tsunami from Augustine Volcano, Alaska-fact or fiction?: Geological Society of America, Abstracts with Programs, v. 28, p. 410.

Waythomas, C.F., 1997, Debris-avalanche-initiated tsunami at Augustine Volcano, Alaska, reexamined: Geological Society of America, Abstracts with Programs, v. 29, p. 73.

Waythomas, C.F., 2000, Reevaluation of tsunami formation by debris avalanche at Augustine Volcano, Alaska: Pure and Applied Geophysics, v. 157, p. 1145-1188.

Waythomas, C.F., and Waitt, R.B., 1998, Preliminary volcano-hazards assessment for Augustine Volcano, Alaska: U.S. Geological Survey Open-File Report 98-106, 39 p., 1 plate.

Waythomas, C.F., Watts, P., and Walder, J.S., 2006, Numerical simulation of tsunami generation by cold volcanic mass flows at Augustine Volcano, Alaska: Natural Hazards and Earth System Sciences, v. 6, p. 671-685.

Wentworth, C.K., 1922, A scale of grade and class terms for clastic sediments: Journal of Geology, v. 30, p. 377-292.

Whelan, F., and Kelletat, D., 2003, Submarine slides on volcanic islands - a source for mega-tsunami in the Quaternary: Progress in Physical Geography, v. 27, p. 198-216.

Williams H., and Goles, G., 1968, Volume of the Mazama ash-fall and the origin of Crater Lake caldera, in Dole, H.M., ed., Andesite Conference guidebook, Oregon State Department of Geology and Mineral Industries Bulletin 62, p. $37-41$.

Winchester, Simon, 2003, Krakatoa - the day the world exploded, August 27, 1883: New York, HarperCollins, 416 p.

Yokoyama, I., 1981, A geophysical interpretation of the 1883 Krakatau eruption: Journal of Volcanology and Geothermal Research, v. 9, p. 359-378.

Young, R., Bryant, E., and Price, D.M., 1996, Catastrophic wave (tsunami?) transport of boulders in southern New South Wales, Australia: Zeitschrift für Geomorphologie, v. 40, p. 191-207.

Yount, M.E., Miller, T.P., and Gamble, B.M., 1987, The 1986 eruptions of Augustine Volcano, Alaska-hazards and effects: U.S. Geological Survey Circular 998, p. 4-13. 
Produced in the Western Region, Menlo Park, California Manuscript approved for publication, February 13, 2009

Layout and graphics by David R. Jones and Christine G. Janda

Back Cover: View east-southeastward of Augustine Volcano from seaward side of hummocky West Island avalanche shed from the volcano about 370 years ago. (USGS photograph by Richard B. Waitt, 19 July 1993.) 


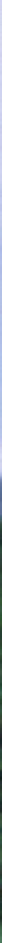

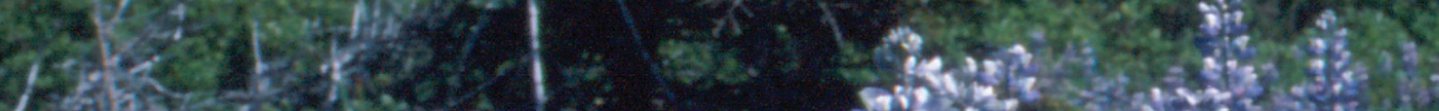

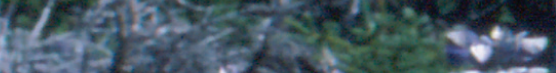

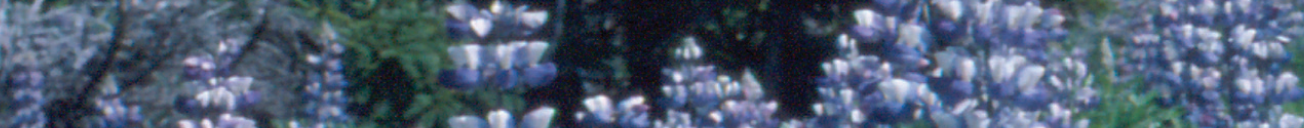
sin:

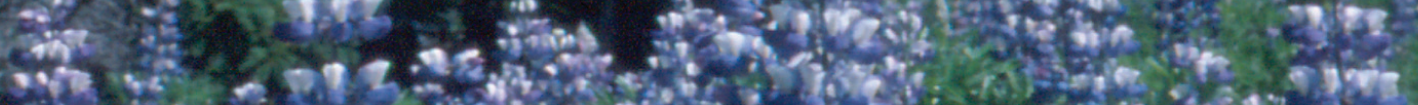

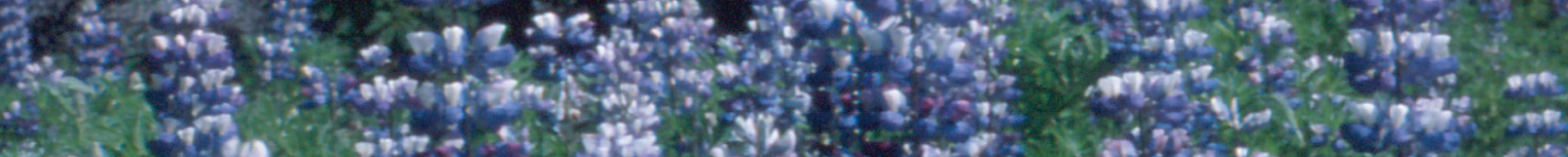

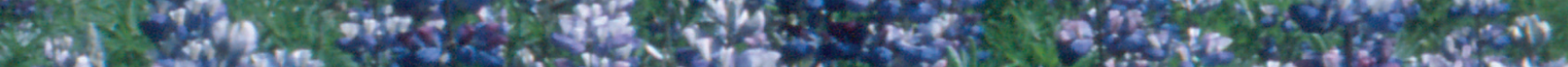

.

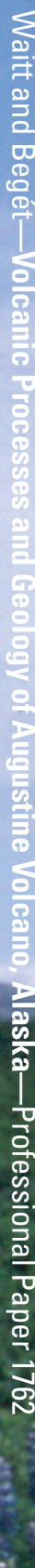
S. E.

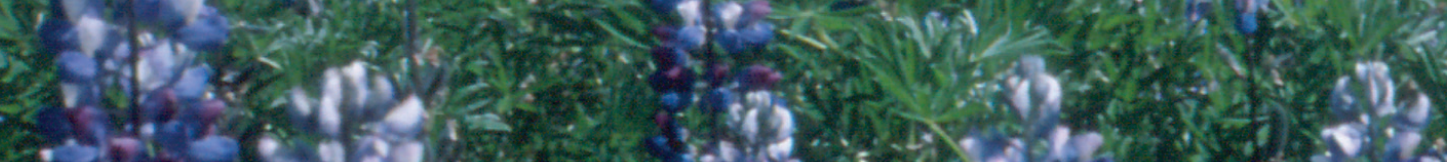

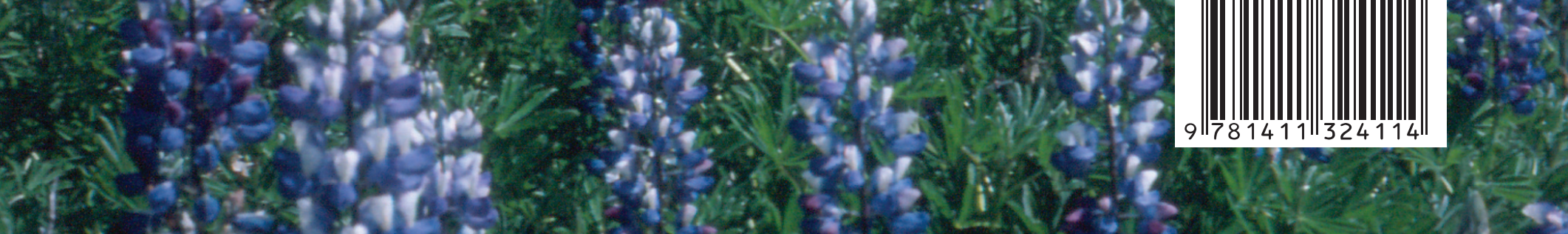

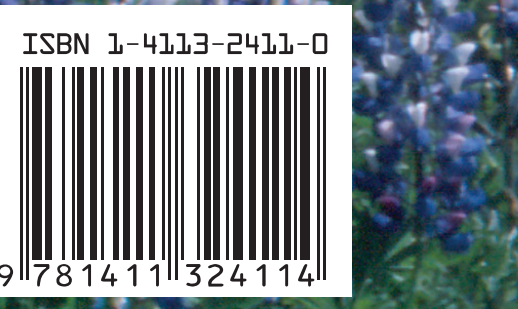

